Florida International University FIU Digital Commons

3-10-2016

\title{
Hospice Psychosocial Service Availability and Utilization in the United States
}

Amary Alcide

Florida International University, amary.alcide@gmail.com

DOI: $10.25148 /$ etd.FIDC000222

Follow this and additional works at: https://digitalcommons.fiu.edu/etd

Part of the Social Work Commons

\section{Recommended Citation}

Alcide, Amary, "Hospice Psychosocial Service Availability and Utilization in the United States" (2016). FIU Electronic Theses and Dissertations. 2504.

https://digitalcommons.fiu.edu/etd/2504

This work is brought to you for free and open access by the University Graduate School at FIU Digital Commons. It has been accepted for inclusion in FIU Electronic Theses and Dissertations by an authorized administrator of FIU Digital Commons. For more information, please contact dcc@fiu.edu. 


\title{
FLORIDA INTERNATIONAL UNIVERSITY
}

Miami, Florida

\section{HOSPICE PSYCHOSOCIAL SERVICE AVAILABILITY AND UTILIZATION IN THE UNITED STATES}

\author{
A dissertation submitted in partial fulfillment of the \\ requirements for the degree of \\ DOCTOR OF PHILOSOPHY \\ in \\ SOCIAL WELFARE \\ by \\ Amary Alcide \\ 2016
}


To: Dean Tomas R. Guilarte

R. Stempel College of Public Health and Social Work

This dissertation, written by Amary Alcide, and entitled Hospice Psychosocial Service Availability and Utilization in the United States, having been approved in respect to style and intellectual content, is referred to you for judgment.

We have read this dissertation and recommend that it be approved.

$\begin{array}{r}\hline \text { Ellen Brown } \\ \hline \text { Barbara Thomlinson } \\ \hline \text { Miriam Potocky } \\ \hline \text { Nicole Ruggiano, Major Professor }\end{array}$

Date of Defense: March 10, 2016

The dissertation of Amary Alcide is approved.

Dean Tomas R. Guilarte R. Stempel College of Public Health and Social Work

Andrés G. Gil Vice President for Research and Economic Development and Dean of the University Graduate School

Florida International University, 2016 


\section{DEDICATION}

This work is dedicated to my loving and supportive family.

I love and thank you for everything.

May the Creator of the world bless you in abundance. 


\section{ACKNOWLEDGMENTS}

Primary acknowledgement goes to the Creator for guiding me in the direction that has led me to this point. Divine intervention is what allowed me to balance family obligations and intense scholarly tasks. Thank you to my family who supported me through the highs and lows of achieving this accolade. My wonderful husband who tirelessly helped me day and night, encouraging me to do what I felt was right and not

pressuring me in either direction. Thank you to my children who have been with me from the beginning and dealt with the difficulties of sharing my attention and energy as I completed my tasks.

I would like to acknowledge the Ronald E. McNair Doctoral Scholars Program for financially supporting me through this process and providing opportunities for underserved populations to excel in academic achievements. Thank you for being true to the vision of support to those who are many times forgotten and dismissed. Individuals from underserved communities need the support of your program and others to elevate beyond the maladaptive elements that tend to plague their lives. Please continue your amazing work and know that all McNair Scholars appreciate its benefits.

Thank you to my entire committee for working seamlessly with me to complete this dissertation. From being available at a moment's notice to allowing me space to develop and independently learn what would be necessary to be a successful scholar. They were always encouraging and understanding of my needs. The four women on my committee, Dr.’s Nicole Ruggiano, Miriam Potocky, Barbara Thomlinson, and Ellen Brown inspire me more than they have realized by being examples of how a woman can be a top scholar and manage family obligations which is many times seen as unrealistic. 
Finally, I would be remised if I did not acknowledge my unique cohort of fellow doctoral students. The combination of personalities, experiences, and intellect was superb and could not have been better. We have become more than colleagues but more like siblings as joy, challenge, and pain built the strong foundation that we will share for the rest of our lives. Antoinette Sappleton and James Melton, you both know how much you mean to me and I love and respect you both. Thank you for keeping me focused and sharing such enlightening wisdom. Peace and Blessings to all. 
ABSTRACT OF THE DISSERTATION

\title{
HOSPICE PSYCHOSOCIAL SERVICE AVAILABILITY AND UTILIZATION IN THE UNITED STATES
}

\author{
by
}

Amary Alcide

Florida International University, 2016

Miami, Florida

\section{Professor Nicole Ruggiano, Major Professor}

Information has been sparse on the hospice psychosocial support offered through the American hospice system. This study examined the hospice psychosocial services that are available and utilized within the United States. In addition, the characteristics of patients and families who utilized these services were comprehensively assessed. Data from the 2007 National Home and Hospice Care Survey (NHHCS) was analyzed in this cross-sectional study (National Center for Health Statistics [NCHS], 2007). Hierarchical linear regression, hierarchal logistic regressions as well as chi-square test of independence were used to analyze the data.

It was hypothesized that for profit hospice ownership status would predict less availability and utilization of psychosocial services when agency size, chain status, and patient total activity of daily needs are controlled. Ownership status was a significant predictor of medical social service availability where for profit agencies were more likely to have this service available. Conversely, hospice patients at for profit agencies were less likely to utilize medical social services as well as bereavement services. 
Overall, patient and caregiver utilization rates of psychosocial services were low with the exception of medical social services, bereavement services, spiritual care services, \& safety training services. The majority of individuals that used these services were married, White, non-Hispanic, 74-75 year old cancer patients with no cognitive impairment. Most were Medicare recipients with advanced directives in place and had 4 ADL needs. Routine home care patients with an average care continuum of about 2-2 1/2 months accounted for most of those who used these services. The majority of these patients lived in a private residence with family members and had spousal caregivers.

These results suggest that the psychosocial services that are being provided have an overall low utilization rate despite availability regardless of ownership type. Further, psychosocial services are disproportionately underutilized by racial and ethnic minorities. In addition, these results highlight the disparity that exists between racial groups that are admitted under hospice care. Further interdisciplinary research needs to be conducted in order to address this disparity in order to determine alternative forms of care that are specifically tailored to a diverse patient population. 


\section{TABLE OF CONTENTS}

CHAPTER

PAGE

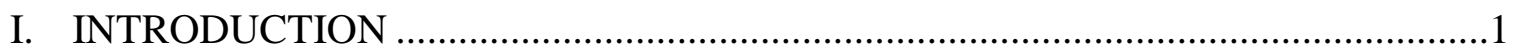

Background of the Study …………………………..........................................

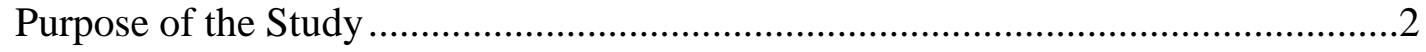

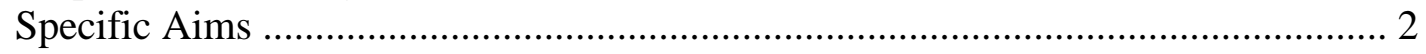

Conceptual Framework .............................................................................................

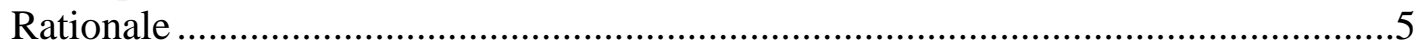

Significance of the Study .................................................................................

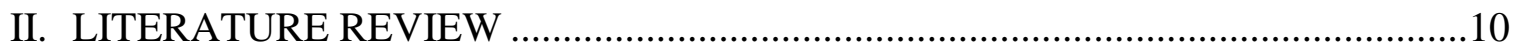

Hospice Philosophy and Services ......................................................................10

Terminal Diagnosis ...........................................................................................10

The Hospice Model.............................................................................................

Location of Service .......................................................................................12

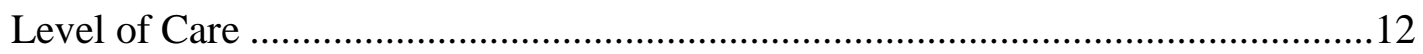

Level of Care, Medicare Reimbursement and Ownership Status ..............................13

Length of Service and Ownership Status..............................................................15

Marketing and Access............................................................................................17

The Cost of For-Profit Hospice Service .............................................................19

The Current State of Hospice Social Work ………………......................................20

Research Questions and Hypotheses .......................................................................24

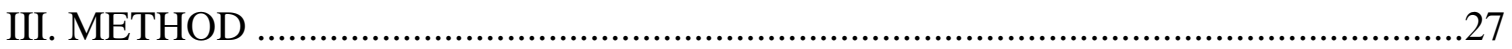

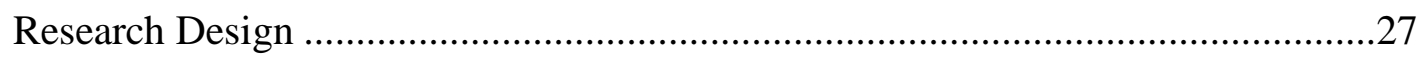

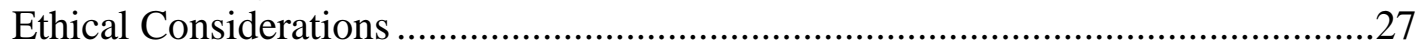

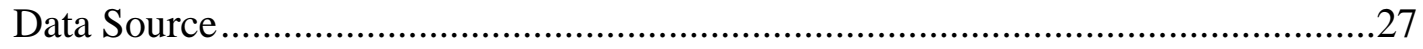

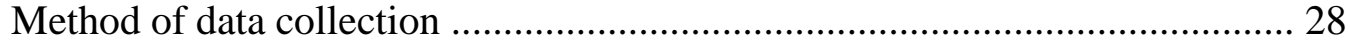

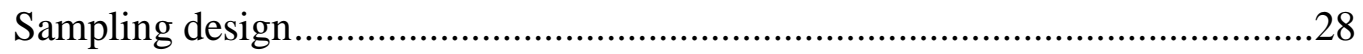

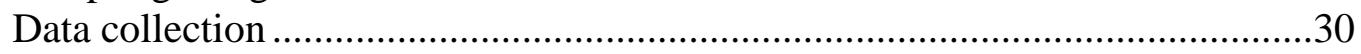

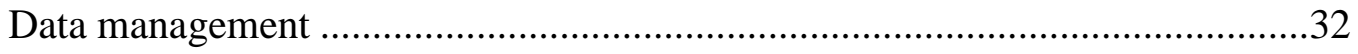

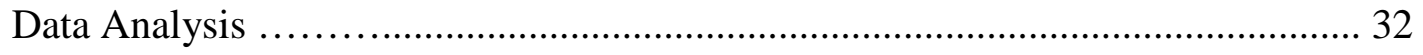

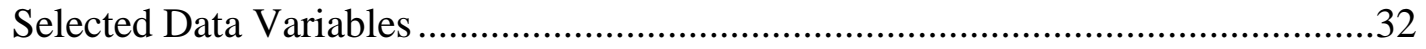

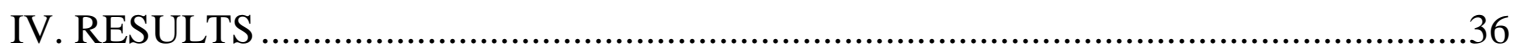

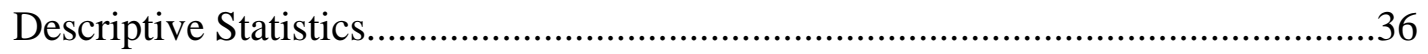

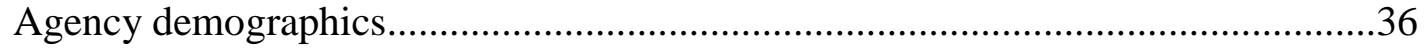

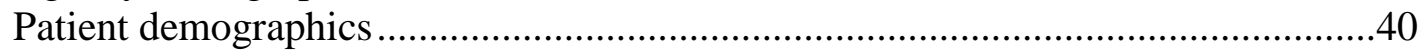

Research Question \#1 .........................................................................................53

Research Question \#2 ………………………………...................................58

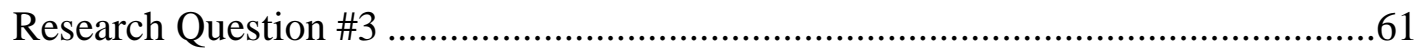

Characteristics of patients who use psychosocial services ........................................62 
Medical social service use and frequency.......................................................62

Resource referral services ........................................................................69

Mental health services .................................................................................

Respite care services ....................................................................................

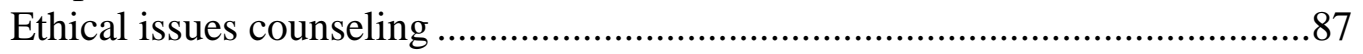

Advanced directive status and psychosocial service utilization ..........................93

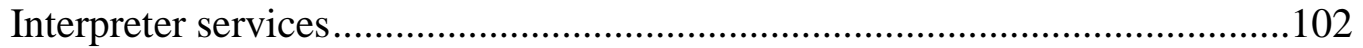

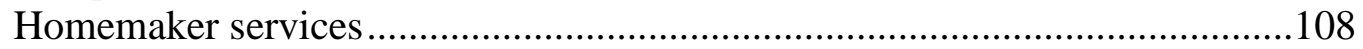

Transportation services ..............................................................................114

Meals on Wheels services..........................................................................120

Contemporary and alternative medicine services .............................................126

Pastoral care services ................................................................................132

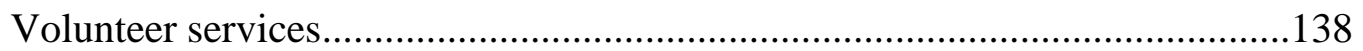

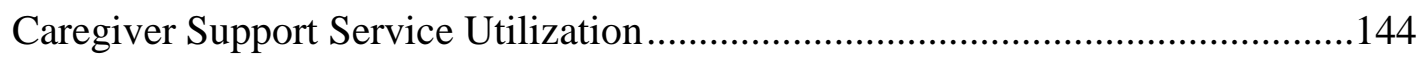

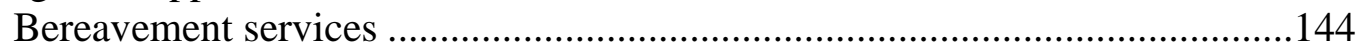

Caregiver health and wellness services ........................................................150

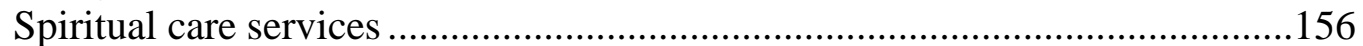

Dealing with difficult behavior services .........................................................162

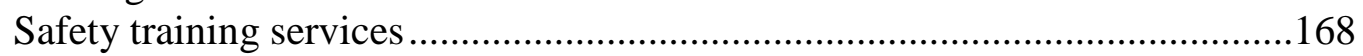

Suspected abuse or neglect services ...............................................................174

Resourced referral information services ........................................................180

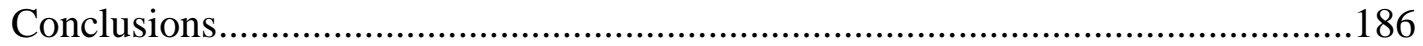

Psychosocial service availability ..................................................................186

Psychosocial service utilization186

Characteristics of consumers that utilize psychosocial services.........................187

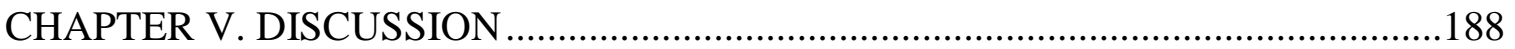

Theoretical Implications .........................................................................................191

Implications for Social Work Research, Policy, Education and Practice ..............194

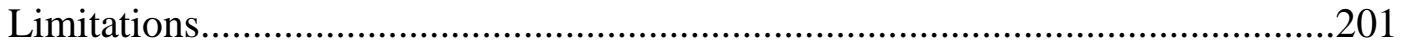

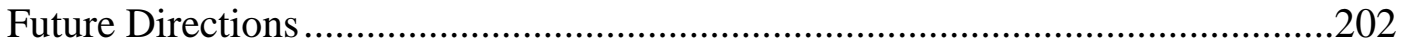

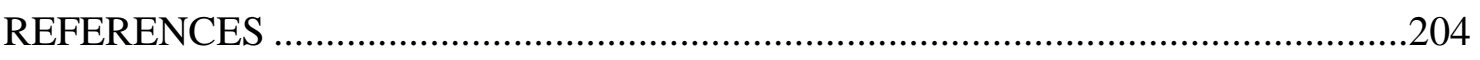

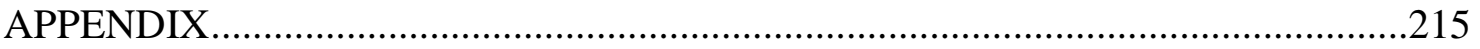

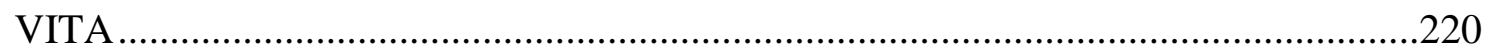




\section{LIST OF TABLES}

TABLE NUMBER

PAGE

1. Hierarchal Logistic Regression Psychosocial Service Availability Based on Hospice Agency Ownership Status.

2. Hierarchal Logistic Regression Psychosocial Service Utilization Based on Hospice Agency Ownership Status.

3. Hierarchal Linear Regression Medical Social Service Visit Frequency Based on Hospice Agency Ownership Status.

4. Patient Medical Social Service Utilization \&Visit Frequency Based on Primary Diagnosis, Cognitive Status, \& Total ADL Needs

5. Patient Medical Social Service Utilization \& Visit Frequency Based on Level of Care, Length of Service, \& Payer Source.

6. Patient Medical Social Service Utilization \&Visit Frequency Based on Age at Discharge, Gender, Race, Ethnicity, Marital Status, \& Veteran Status.

7. Patient Medical Social Service Utilization \& Visit Frequency Based on Caregiver Status \& Household Membership

8. Patient Medical Social Service Utilization \& Visit Frequency Based on Patient Location at the Beginning \& End of Care

9. Patient Utilization of Resource Referral Services Based on Primary Diagnosis, Cognitive Status, \& Total ADL Needs

10. Patient Utilization of Resource Referral Services Based on Level of Care, Length of Service, \& Payer Source

11. Patient Resource Referral Service Utilization Age at Discharge, Gender, Race, Ethnicity, Marital Status, \& Veteran Status

12. Patient Resource Referral Service Utilization Caregiver Status, \& Household Membership

13. Patient Resource Referral Service Utilization \& Patient Location at the Beginning as Well as End of Care.

14. Patient Utilization of Mental Health Services Based on Primary Diagnosis, Cognitive Status, \& Total ADL Needs 
15. Patient Utilization of Mental Health Services Based on Level of Care, Length of Service, \& Payer Source.

16. Patient Mental Health Service Utilization, Age at Discharge, Gender, Race, Ethnicity, Marital Status, \& Veteran Status

17. Patient Mental Health Service Utilization, Caregiver Status, \& Household Membership

18. Patient Mental Health Service Utilization \& Patient Location at the Beginning as Well as End of Care

19. Patient Utilization of Respite Services Based on Primary Diagnosis, Cognitive Status, \& Total ADL Needs

20. Patient Utilization of Respite Services Based on Level of Care, Length of Service, \& Payer Source

21. Patient Respite Service Utilization, Age at Discharge, Gender, Race, Ethnicity, Marital Status, \& Veteran Status

22. Patient Respite Service Utilization, Caregiver Status, \& Household Membership

23. Patient Respite Utilization \& Patient Location at the Beginning as Well as End of Care

24. Patient Utilization of Ethical Issues Counseling Based on Primary Diagnosis, Cognitive Status, \& Total ADL Needs

25. Patient Utilization of Ethical Issues Counseling Based on Level of Care, Length of Service, \& Payer Source.

26. Patient Ethical Issues Counseling Utilization, Age at Discharge, Gender, Race, Ethnicity, Marital Status, \& Veteran Status

27. Patient Ethical Issues Counseling Utilization, Caregiver Status, \& Household Membership

28. Patient Ethical Issues Counseling Utilization \& Patient Location at the Beginning as Well as End of Care. 
29. Patient Advanced Directive Status, Primary Diagnosis, Cognitive Status, \& Total ADL Needs

30. Patient Advanced Directive Status, Level of Care, Length of Service, \& Payer Source

31. Patient Advanced Directive Status, Age at Discharge, Gender, Race, Ethnicity, Marital Status, \& Veteran Status

32. Patient Advanced Directive Status, Caregiver Status, \& Household Membership

33. Patient Advanced Directive Status \& Patient Location at the Beginning as Well as End of Care

34. Patient Utilization of Psychosocial Services Based on Advanced Directive Status.

35. Caregiver Utilization of Psychosocial Services Based on Patient Advanced Directive Status.

36. Patient Utilization of Interpreter Services Based on Primary Diagnosis, Cognitive Status, \& Total ADL Needs

37. Patient Utilization of Interpreter Services Based on Level of Care, Length of Service, \& Payer Source

38. Patient Utilization of Interpreter Services, Age at Discharge, Gender, Race, Ethnicity, Marital Status, \& Veteran Status

39. Patient Utilization of Interpreter, Caregiver Status, \& Household Membership

40. Patient Utilization of Interpreter \& Patient Location at the Beginning as Well as End of Care

41. Patient Utilization of Homemaker Services Based on Primary Diagnosis, Cognitive Status, \& Total ADL Needs

42. Patient Utilization of Homemaker Services Based on Level of Care, Length of Service, \& Payer Source.

43. Patient Utilization of Homemaker Services, Age at Discharge, Gender, Race, Ethnicity, Marital Status, \& Veteran Status 
44. Patient Utilization of Homemaker Services, Caregiver Status, \& Household Membership

45. Patient Utilization of Homemaker Services \& Patient Location at the Beginning as Well as End of Care....

46. Patient Utilization of Transportation Services Based on Primary Diagnosis, Cognitive Status, \& Total ADL Needs

47. Patient Utilization of Transportation Services Based on Level of Care, Length of Service, \& Payer Source....

48. Patient Utilization of Transportation Services, Age at Discharge, Gender, Race, Ethnicity, Marital Status, \& Veteran Status.

49. Patient Utilization of Transportation Services, Caregiver Status, \& Household Membership

50. Patient Utilization of Transportation Services \& Patient Location at the Beginning as Well as End of Care.

51. Patient Utilization of Meals on Wheels Services Based on Primary Diagnosis, Cognitive Status, \& Total ADL Needs

52. Patient Utilization of Meals on Wheels Services Based on Level of Care, Length of Service, \& Payer Source.

53. Patient Utilization of Meals on Wheels Service, Age at Discharge, Gender, Race, Ethnicity, Marital Status, \& Veteran Status.

54. Patient Utilization of Meals on Wheels Services, Caregiver Status, \& Household Membership

55. Patient Utilization of Meals on Wheels Services \& Patient Location at the Beginning as Well as End of Care

56. Patient Utilization of CAM Services Based on Primary Diagnosis, Cognitive Status, \& Total ADL Needs

57. Patient Utilization of CAM Services Based on Level of Care, Length of Service, \& Payer Source

58. Patient Utilization of CAM Services, Age at Discharge, Gender, Race, Ethnicity, Marital Status, \& Veteran Status 
59. Patient Utilization of CAM Services, Caregiver Status, \& Household Membership

60. Patient Utilization of CAM Services \& Patient Location at the Beginning as Well as End of Care

61. Patient Utilization of Pastoral Care Services Based on Primary Diagnosis, Cognitive Status, \& Total ADL Needs

62. Patient Utilization of Pastoral Care Services Based on Level of Care, Length of Service, \& Payer Source.

63. Patient Utilization of Pastoral Care Services, Age at Discharge, Gender, Race, Ethnicity, Marital Status, \& Veteran Status.

64. Patient Utilization of Pastoral Care Services, Caregiver Status, \& Household Membership

65. Patient Utilization of Pastoral Care Services \& Patient Location at the Beginning as Well as End of Care....

66. Patient Utilization of Volunteer Services Based on Primary Diagnosis, Cognitive Status, \& Total ADL Needs

67. Patient Utilization of Volunteer Services Based on Level of Care, Length of Service, \& Payer Source

68. Patient Utilization of Volunteer Services, Age at Discharge, Gender, Race, Ethnicity, Marital Status, \& Veteran Status

69. Patient Utilization of Volunteer Services, Caregiver Status, \& Household Membership

70. Patient Utilization of Volunteer Services \& Patient Location at the Beginning as Well as End of Care....

71. Caregiver Utilization of Bereavement Services Based on Patient Primary Diagnosis, Cognitive Status, \& Total ADL Needs

72. Caregiver Utilization of Bereavement Services Based on Patient Level of Care, Length of Service, \& Payer Source.

73. Caregiver Utilization of Bereavement Services Based on Patient Age at Discharge, Gender, Race, Ethnicity, Marital Status, \& Veteran Status. 
74. Caregiver Utilization of Bereavement Services Based on Patient Caregiver Identification \& Household Membership

75. Caregiver Utilization of Bereavement Services Based on Patient Location at the Beginning as Well as End of Care

76. Caregiver Utilization of Health \& Wellness Services Based on Patient Primary Diagnosis, Cognitive Status, \& Total ADL Needs

77. Caregiver Utilization of Health \& Wellness Services Based on Patient Level of Care, Length of Service, \& Payer Source.

78. Caregiver Utilization of Health \& Wellness Services Based on Patient Age at Discharge, Gender, Race, Ethnicity, Marital Status, \& Veteran Status

79. Caregiver Utilization of Health \& Wellness Services Based on Patient Caregiver Identification \& Household Membership.

80. Caregiver Utilization of Health \& Wellness Based on Patient Location at the Beginning as Well as End of Care

81. Caregiver Utilization of Spiritual Services Based on Patient Primary Diagnosis, Cognitive Status, \& Total ADL Needs

82. Caregiver Utilization of Spiritual Services Based on Patient Level of Care, Length of Service, \& Payer Source.

83. Caregiver Utilization of Spiritual Services Based on Patient Age at Discharge, Gender, Race, Ethnicity, Marital Status, \& Veteran Status.

84. Caregiver Utilization of Spiritual Services Based on Patient Caregiver Identification \& Household Membership

85. Caregiver Utilization of Spiritual Services Based on Patient Location at the Beginning as Well as End of Care

86. Caregiver Utilization of Dealing with Difficult Behaviors Services Based on Patient Primary Diagnosis, Cognitive Status, \& Total ADL Needs

87. Caregiver Utilization of Dealing with Difficult Behaviors Services Based on Patient Level of Care, Length of Service, \& Payer Source 
88. Caregiver Utilization of Dealing with Difficult Behaviors Services Based on Patient Age at Discharge, Gender, Race, Ethnicity, Marital Status, \& Veteran Status.

89. Caregiver Utilization of Dealing with Difficult Behaviors Services Based on Patient Caregiver Identification \& Household Membership .166

90. Caregiver Utilization of Dealing with Difficult Behaviors Services Based on Patient Location at the Beginning as Well as End of Care

91. Caregiver Utilization of Safety Training Services Based on Patient Primary Diagnosis, Cognitive Status, \& Total ADL Needs

92. Caregiver Utilization of Safety Training Services Based on Patient Level of Care, Length of Service, \& Payer Source.

93. Caregiver Utilization of Safety Training Services Based on Patient Age at Discharge, Gender, Race, Ethnicity, Marital Status, \& Veteran Status....

94. Caregiver Utilization of Safety Training Services Based on Patient Caregiver Identification \& Household Membership

95. Caregiver Utilization of Safety Training Services Based on Patient Location at the Beginning as Well as End of Care

96. Caregiver Utilization of Suspected Abuse or Neglect Services Based on Patient Primary Diagnosis, Cognitive Status, \& Total ADL Needs

97. Caregiver Utilization of Suspected Abuse or Neglect Services Based on Patient Level of Care, Length of Service, \& Payer Source .176

98. Caregiver Utilization of Suspected Abuse or Neglect Services Based on Patient Age at Discharge, Gender, Race, Ethnicity, Marital Status, \& Veteran Status

99. Caregiver Utilization of Suspected Abuse or Neglect Services Based on Patient Caregiver Identification \& Household Membership ....

100. Caregiver Utilization of Suspected Abuse or Neglect Services Based on Patient Location at the Beginning as Well as End of Care....

101. Caregiver Utilization of Resource Referral Information Services Based on Patient Primary Diagnosis, Cognitive Status, \& Total ADL Needs 
102. Caregiver Utilization of Resource Referral Information Services Based on Patient Level of Care, Length of Service, \& Payer Source

103. Caregiver Utilization of Resource Referral Information Services Based on Patient Age at Discharge, Gender, Race, Ethnicity, Marital Status, \& Veteran Status

104. Caregiver Utilization of Resource Referral Information Services Based on Patient Caregiver Identification \& Household Membership

105. Caregiver Utilization of Resource Referral Information Services Based on Patient Location at the Beginning as Well as End of Care. 


\section{LIST OF FIGURES}

FIGURE NUMBER

PAGE

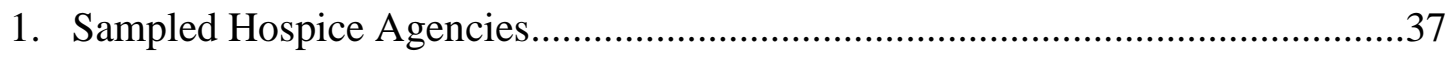

2. Hospice Medical Social Work Service Availability .........................................37

3. Hospice Respite, Transportation, \& Meals on Wheels Service Availability ..........38

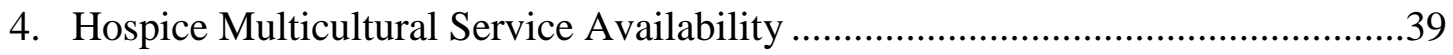

5. Pastoral, Volunteer, \& Optional Supportive Care Hospice

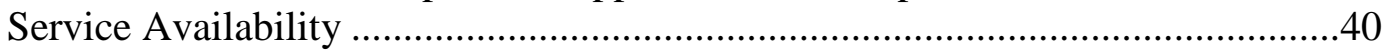

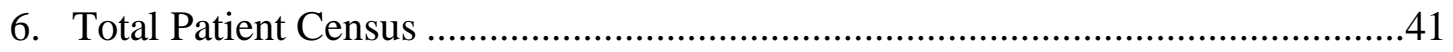

7. Most Common Patient Diagnoses at For Profit Hospices ...................................41

8. Most Common Patient Diagnoses at Not-for Profit or Government Owned

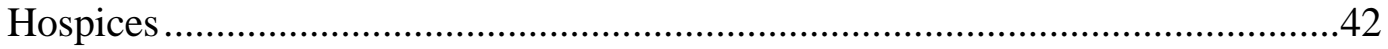

9. Average Patient Cognitive Status at For Profit Hospices ...................................42

10. Average Patient Cognitive Status at Not-for-Profit of Government Owned

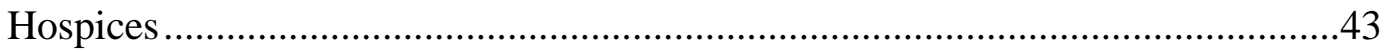

11. Average Total Patient ADL Needs at For Profit Hospices ..................................43

12. Average Total Patient ADL Needs at Not-for Profit of Government Owned Hospices ........................................................................................44

13. Average Amount of Hospice Patients with Advanced Directives ........................44

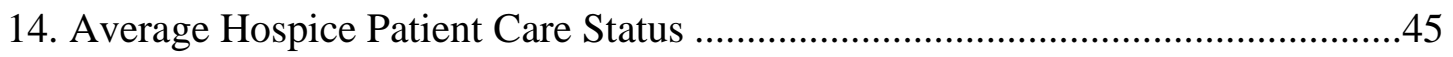

15. Average Patient Length of Service at Hospice Agencies ...................................45

16. Average Age of Hospice Patients .................................................................46

17. Average Gender and Veteran Status of Hospice Patients ...................................47

18. Average Patient Marital Status at For Profit Hospices .....................................47 
19. Average Patient Marital Status at Not-for-Profit and Government Owned

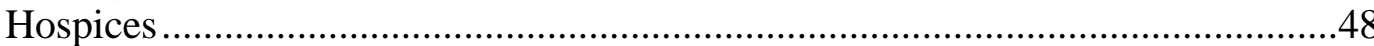

20. Racial Demographics of Hospice Patients .......................................................48

21. Ethnic Demographics of Hospice Patients....................................................49

22. Primary Patient Payer Sources at For Profit Hospices........................................50

23. Primary Patient Payer Sources at Not-for-Profit and Government

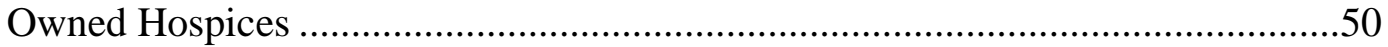

24. Hospice Patient Caregiver Status ...................................................................... 51

25. Hospice Patient Household Membership ............................................................51

26. Hospice Patient Specific Household Membership with Family Members ............52

27. Patient Location of Residence at the Beginning of Hospice Care .........................52

28. Patient Location of Residence at the End of Hospice Care ..................................53 


\section{CHAPTER I: INTRODUCTION}

\section{Background of the Study}

Hospice services provide specialized care which assists terminally ill patients and their families through the transitions that occur at the end-of-life (National Hospice and Palliative Care Organization [NHPCO], 2013a; Saunders, 2000). The quality of support services provided by a Medicare approved hospice provider is pinnacle during this vulnerable time in life. Unfortunately, little is known about the psychosocial services, interventions, outcomes and quality of services within the American hospice care system (Reese, 2013).

The nearly 20\% influx in for-profit hospice providers since the year 2000 has sparked immense debate regarding the commercialization of this form of care and the possible impacts on service delivery, profitability, ethical practice, and possible quality variations based on ownership status (Ata et al., 2013; Perry \& Stone, 2011; Sack, 2007; “The Debate in Hospice Care”, 2008).

Researchers have begun to examine this dynamic to evaluate if and/or to what extent this change in the hospice industry has empirically significant and practical effects. Hospice provider ownership status has been correlated with variables such as patient diagnosis, the manner in which patients are selected for admission, agency engagement with their respective community engagement, and staff characteristics (Aldridge et al., 2014; Carlson et al., 2004; Gandhi, 2012; Wachterman et al., 2011). However, there have not been any studies published that have comprehensively examined hospice psychosocial service availability and usage. 


\section{Purpose of the Study}

This study aimed to examine hospice psychosocial services that are available and utilized within the United States. In addition the characteristics of patients and families utilizing these services were comprehensively assessed.

\section{Specific Aims}

The general aim of this study is to examine hospice psychosocial services and the factors associated with the utilization of these services within American hospice care settings.

Specific Aim 1: Examine the availability of psychosocial services at for profit versus other hospice agencies (not-for-profit and government owned). What types of psychosocial services are being provided by hospice agencies?

Specific Aim 2: Examine the probability of psychosocial service utilization by patient and family members at for profit and other hospice agencies. What types of psychosocial services are being utilized at hospices of different ownership types?

Specific Aim 3: Examine the psychosocial services that are most frequently utilized and the characteristics of the consumers that use this form of hospice care. Which psychosocial services are utilized the most? What are the factors associated with hospice psychosocial utilization by consumers?

\section{Conceptual Framework}

The Life-Span Development Theory highlights the needs of the aging population by detailing issues that can occur during transitions throughout life (Hoyer, 2002). This theory states that the process of aging is multidimensional which presents a litany of needs that fluctuate as the individual experiences gains and losses (Hoyer, 2002). When a 
hospice patient and families are faced with the complexities at the end of life, optimal care that addresses these issues becomes essential.

A major component within the development of hospice as a professionalized service was the holistic, interdisciplinary perspective of care that addresses "total pain" (Saunders, 2001). One of the most important factors for patients and families is the desire for the patient to have a peaceful death (Ruland \& Moore, 1998). Complementary to the initial aim of professionalized hospice care, The Peaceful End of Life Theory stipulates that in order to have a peaceful death experience, there needs to be a facilitation of the patient not experiencing any pain but feels a sense of peace, closeness to family members, dignity, and comfort (Ruland \& Moore, 1998).

The aforementioned perspectives take into account all aspects of the patient's interpersonal, intra-personal, and environmental elements thereby facilitating a plan of care that addresses the needs of patient and families comprehensively. However, when there are organizational models that limit the facilitation of optimal care, hospice patients and families may not receive the highest quality of services that have been the foundation of the hospice philosophy since its inception.

Traditional microeconomic theory states that corporations faced with scarce resources are motivated to maximize profit using the available resources for what is considered the most needed or essential services all while minimizing expenditures (Hosmer, 1984). The key focus of the theory is the examination of preference relations which is how the choices made available to corporations and consumers can influence service availability and utilization practices (Hosmer, 1984; Nicholson \& Snyder, 2008). 
The focus on profit maximization can be explained by the notion of altruism and egoism. Altruistic motives emphasize the needs of others without focusing on the benefits that may or may not be warranted based on the assistance provided (Bar-Tal, 1986). Conversely, those who are egoistic, are more likely to be motivated to provide assistance purely based on self-interest and the rewards that will be fostered by helping others (Henson, 1988). It is from this theory where the concept of "profit motive" stems and has drawn concern from critics of the for-profit movement in healthcare (Brock \& Buchanan, 1987; profit motive, 2002).

There are polarized arguments as it pertains to the appropriateness that the motivation of financial gain has in the field of medicine with an even more intensive debate when focused on end-of-life care. From the business perspective, cost savings and access have been used as the forthcoming arguments to promote the influx in for-profit hospice providers (“The Debate in Hospice Care”, 2008; Kinzbrunner, 2002). However, when the practice tendencies of for-profit hospice providers have been examined, results lend to ethical concerns regarding patient selection, referral sources, admitting diagnoses, location of care, and length of stay (Aldridge et al., 2014; Carlsen, et al., 2004; Cherlin, 2010; Gahndi et al., 2012; Lindrooth \& Weisbrod, 2007; Wachterman et al., 2011). This begs the question of how much a profit driven motive can affect the care provided to hospice patients and their families.

The Contract Failure Theory states that when the quality and quantity of services are restricted, not-for-profit utilization increases because of the expectation of not-forprofit emphasis on quality (Hansmann, 1980). On the other hand, the theory postulates that for-profits under this same constraint are afforded the incentive to exploit vulnerable 
service consumers (Hansmann, 1980). It is theoretically possible that due to the vulnerability of the hospice population, for-profit hospice providers may delineate from providing adequate psychosocial services to patients and families due to the current limited scope of attention to this domain of hospice service.

When business models are enforced to meet stakeholder demands and team members such as social workers are limited in their practice capacity due to agency financial motives, hospice patients and their families may be deprived of essential attention and all-inclusive care. Care that takes not just the terminal disease process or financial gain into account, but also all of the psychological, environmental, social, economic and cultural aspects of their lives. If the psychosocial services that hospice social workers are not seen as essential services, then more harm than good can result. This study aims to examine this dynamic with attention to ownership status, service availability, and characteristics of service utilization. The following section will provide the rationale for the study.

\section{Rationale}

National data evaluating the outcomes and perceived quality of hospice service availability in the United States has not been regulated by Medicare until recently. Hospice Medicare has begun to aim towards more rigorous evaluation of patient outcomes and quality (MedPAC, 2013). As of June 2014, all assessments conducted by the interdisciplinary hospice team must incorporate the Hospice Item Set (HIS) tool (CMS, 2014b). Review of the current HIS data elements reveal that as it pertains to psychosocial dimensions, the tool only evaluates whether or not patient and/or caregiver values and beliefs (as desired by the patient and/or family) have been addressed by the 
interdisciplinary team based on medical record review (CMS, 2014b). These measurement items are not to be utilized as assessment tools but for outcome measurement and data collection (CMS, 2014b). According to CMS (2014b), the HIS can be added to current assessments and augmented as deemed appropriate by each respective agency. This presents potential empirical issues of validity and could present problems of bias.

As a part of the national performance improvement initiative, NHPCO has developed a National Data Set (NDS) (NHPCO, 2014b). The NDS tool is administered annually by NHPCO to its member agencies and is considered to be a comprehensive evaluation of hospice operations including care recipients, care providers, cost and quality of services (NHPCO, 2014b). Though the data collected provides key information regarding the general operations and patient demographics of hospice agencies around the country, it does not evaluate utilization of services An additional limitation is that the tool aims to evaluate quality of services but the data is not based on consumer perspective and the concept of what quality measures are being evaluated remains unclear.

NHPCO has also developed the Family Evaluation of Hospice Care (FEHC) survey which is sent quarterly to bereaved hospice family members to assess their perception of the quality of care (NHPCO, 2014b). Further analysis of the items on this survey reveal that the only psychosocial concepts evaluated are help with sad ness, anxiety, and emotional support. There is no indication of other psychosocial concepts such as referral assistance or ethical issues counseling. This is reflective of the CMS (2014a) guidelines indicating emotional support as an important outcome but negates any other psychosocial aspects that are in fact key elements to address during end-of-life care. 
Much of the empirical focus to-date has been on the hospice team's management of the physical problems faced by patients with the main goal of pain reduction. There is limited focus on the practical evaluation of the prevalence, intervention, and measurement of outcomes involved with the psychosocial factors present with hospice patients and caregivers (Reese, 2013).Currently, there is no standardization in comprehensive psychosocial assessment, intervention, nor outcome tool delivered across hospice providers (Reese, 2013). There has been one psychosocial outcome measure developed and piloted specifically for hospice social worker use, the Social Work Assessment Tool (SWAT) (Reese, 2013; Reese et al., 2006). However, this measure needs further validation and reliability prior to any dissemination for data collection.

The limitations present in the current national evaluation of service availability, utilization, outcomes, and quality of hospice psychosocial services reveal that there is a significant amount of empirical investigation that can be done to address these matters. The proposed study will initiate investigation into psychosocial hospice services by examining the constructs identified under the hospice social worker role as indicated by empirical literature (Christ \& Blacker, 2009; Reese, 2011; Reese, 2013; Reese \& Raymer, 2004; Reese et al., 2006; Reith \& Payne, 2009; Saunders, 2001). These constructs (resource referral, mental health counseling, advanced directive counseling, respite care linkage as well as grief and bereavement counseling) have also been identified by hospice regulatory and organizational bodies CMS (2014a), NHPCO (2013a), and NASW (2004) as components of the hospice social work role. 


\section{Significance of the Study}

The psychosocial component is important because of the existence of not only physical symptomology at the end of life but also the emotional, mental, and social impact that the disease process can have on both hospice patients and families. The following section will further highlight the significance of examining psychosocial service availability and utilization in the hospice industry.

Terminally ill adult patients can suffer from increased pain, emotional distress from a debilitating disease process, as well as limited support as they progress through the stages of the disease with increased need (Buckey \& Abell, 2010; Chochinov et al., 2002). To address this need, hospice services have become a growing source of support for terminally ill patients and their families as indicated by the increase of service utilization since the service became nationally available in the early 1980's (Miller \& Mike, 1995).

As an integral part of hospice services, psychosocial support can help address end-of-life issues such as denial, death anxiety, maladaptive coping, lack of social support, financial resource limitations, as well as ethical issues such as artificial nutrition and non-resuscitation (Bath, 2010; Reese, 2013; Reith \& Payne, 2009 Werth et al., 2002). As a whole, both patients and their loved ones desire a "good death" experience and that is defined based on societal and cultural norms (Kearl, 2009; Pleacher, 2011). Despite some variances, a common factor among those experiencing the process of death is the mitigation of physical, emotional, and societal pain as best possible with peace and serenity (Saunders, 2000). In addition, the availability of medical professionals that are culturally competent, compassionate, and knowledgeable about the care of the dying and 
their loved ones are pinnacle in the perceptions of the experiences that people face at this time in life (Pleacher, 2011).

These are some of the reasons why examination of psychosocial services remains significant (Reese, 2013). There have been a few foundational studies of hospice psychosocial interventions. Results of these studies indicate positive clinical outcomes such as reduction of caregiver stress and anxiety, with increased problem-solving skills as well as quality of life (Allen et al., 2008; Carter, 2006; Csikai et al., 2013; Dimiris et al., 2010; Dimiris et al., 2012; Drossel et al., 2011; Empeño et al., 2011; Gordon, 2013; Keefe et al., 2005; Kilburn et al., 2011; Kruse et al., 2013; McMillan et al., 2006; McMillan et al., 2007; Moody, 2004; Northouse et al., 2007; Northouse et al., 2013; Ott \& Lueger, 2002; \& Steinhauser et al., 2009; Washington et al., 2012). However, comprehensive hospice psychosocial service delivery and consumer utilization remains understudied (Reese, 2013; Reese \& Raymer, 2004).

The relevance of psychosocial services and utilization based on hospice agency ownership status may influence quality, duration, and type of service. Psychosocial intervention implementation and outcomes may also be informed. Furthermore, having a clear understanding of psychosocial services and service utilization can inform policy makers, stakeholders, as well as hospice consumers regarding future choices related to end-of-life care. The following section will review the hospice philosophy as well as the services that are provided. 


\section{CHAPTER II: LITERATURE REVIEW}

\section{Hospice Philosophy and Services}

The modern model of hospice care was initiated in London during 1967 by Dame Cicely Saunders (Corr, 2009). Hospice was formally established in the US during 1974 and has grown significantly since that time (Saunders, 2000). The most recent data from the Facts and Figures report from NHPCO (2013b) shows that as of 2012, there are over 5, 500 hospices nation-wide including U.S. territories the U.S. Virgin Islands, Puerto Rico, and Guam. Most of these agencies are free-standing hospices (not a part of a home health agency, hospital system, or nursing home), located in urban areas, and serve an average of about 149 patients per day (MedPAC, 2011; NHPCO, 2013b).

Hospice provides support for patients with a medically certified terminal diagnosis where if the disease runs its normal course, they are not expected to survive more than six months and must be recertified by a medical physician every three months (Rhymes, 1990). Initiated in 1982 under the Tax Equity and Fiscal Responsibility Act (TEFRA), services are covered fiscally by the Hospice Medicare Benefit and regulated by Centers for Medicare and Medicaid Services (Miller \& Mike, 1995). This coverage includes the medical care provided during the visits by the interdisciplinary hospice team, patient pharmaceutical needs, durable medical equipment including oxygen, as well as supporting medical supplies (Morefield et al., n.d.).

\section{Terminal Diagnosis}

There are several terminal diagnoses that qualify a patient for hospice care. Since the 1970's when the majority of the patients served were diagnosed with cancer, the statistics show that over half of those who receive hospice care have been ascribed 
terminal diagnoses of conditions other than cancer (that is Unspecified Debility, Dementia, Heart Disease, Lung Disease, Stroke/Coma, Liver Disease, Amyotrophic Lateral Sclerosis (ALS) and Non-ALS Motor Neuron, as well as AIDS) (National Hospice and Palliative Care Organization, 2013). Hospice eligibility of these diseases are defined by the Medicare guidelines for determining terminal status (CMS, 2014b).

\section{The Hospice Model}

The interdisciplinary team providing hospice care consists of an attending physician, registered nurse, certified nurse assistant, medical social worker, spiritual counselor, volunteer, and other supporting professionals such as integrative therapists (CMS, 2012; Lutz, 2011). Besides mandating specific supportive care professionals, the hospice Medicare guidelines require each of the aforementioned healthcare professionals to provide care in order for the hospice to be certified (CMS, 2012). The team members address the patient's “total pain” needs; a concept developed by Cicely Saunders as physical, psychological, social, and spiritual issues affecting a dying patient (Arber, 2007; Oliver et al., 2008; Saunders, 2001).

Specifically, the main responsibilities of the team are to: manage pain and symptoms of the patient as well as provide the necessary medications, medical equipment, and supporting medical supplies that are related to the patient diagnosis (National Hospice and Palliative Care Organization [NHPCO], 2013a). In addition NHPCO (2013a) states that each hospice team provides education on patient care as well as emotional and spiritual support to both the patient and family. Grief support is also provided to surviving friends and family post-death of the patient (NHPCO, 2013a). 
These services, among others, are collectively and extensively provided based on the team member's professional expertise and patient/family needs (NHPCO, 2013b).

\section{Location of Service}

Hospice services can be provided in the patient's primary residence such as an assisted living facility, private residence, or skilled nursing facility (Hospice Foundation of America, 2013). In addition, some hospice agencies have freestanding inpatient units or can provide services in a hospital where there is a contracted hospice unit or beds use specifically for hospice patients according to the Hospice Foundation of America (2013). To-date, $66 \%$ of hospice services are provided to patients in residencies with just over 40\% percent of those patients living in private homes (NHPCO, 2013b).

\section{Level of Care}

The patients receive the interdisciplinary team services under one of four different levels of care. These care levels, based on Medicare requirements, are categorized under either home-based care (routine home care and continuous home care) or inpatient care (general inpatient care and inpatient respite care) (NHPCO, 2013b). Routine Home Care is the standard level of service within the patient's place of residence where the entire team provides the appropriate services based on the need expressed in the patient plan of care (NHPCO, 2013b). According to NHPCO (2013), this level of care accounted for over 95\% percent of the care provided in 2012.

The Centers for Medicare and Medicaid Services [CMS] (2008) defines Continuous Home Care as the level in which a patient receives the standard hospice services at his or her residence in addition to a minimum of eight hours of nursing care within a 24 hour period. This aspect of service is initiated due to unmanaged symptoms, 
such as pain and/or discomfort. This service is temporary and the patient is placed on Routine Home Care level of service once symptoms have been effectively managed or the patient is declared deceased (CMS, 2008; NHPCO, 2013b).

There may be times when a patient has uncontrolled pain or acute to complex symptoms that cannot be assuaged by the hospice team in other settings such as within the home. This may indicate that the patient should be admitted to an inpatient facility, such as a free standing hospice unit or one within a hospital, and placed under the General Inpatient level of care until the symptoms are managed or the patient dies (NHPCO, 2013b). Finally, the Medicare Hospice Benefit provides coverage for shortterm respite care, defined as Inpatient Respite Care, which provides intermediate relief for the nonprofessional providing care, the caregiver (s), by placing the patient in an approved facility based on state regulations (caregivers, 2014; NHPCO, 2013b).

Medicare reimbursement for hospice services is dependent on patient level of care (Wachterman et al., 2011). Since the majority of hospice patients are Hospice Medicare recipients, how a provider will operate can have certain effects. The next section will detail how the ownership status may influence patient level of care, Medicare reimbursement.

\section{Level of Care, Medicare Reimbursement and Ownership Status}

At the beginning of every Medicare year (November 1), a daily or hourly base rate is established and adjusted according to the wages of the agency's local geographic market (Ata et al., 2013; MedPAC, 2013). The rates for routine home care, general inpatient care, or inpatient respite care are daily while continuous care rate is provided at an hourly rate due to intensified care needs (MedPAC, 2013). 
Despite the base rate equality across hospice types, there has been a significant increase of for-profit hospice providers and a slow reduction in the amount of not-forprofit providers since 2000 (Wachterman et al., 2011). The most recent MedPAC data provided to congress indicates that in the year 2000, there were about 672 for-profit hospice agencies and 1, 323 not-for-profit agencies nationwide (MedPAC, 2013). Then, MedPAC (2013) reports that between 2000 and 2007, there was a nearly 14\% increase in for-profit hospice providers while only .1\% of not-for-profit numbers increased.

The amount of for-profit hospice agencies continued to increase between 2007 and 2010 by 5.2\% while interestingly, the not-for-profit hospices began to decline by .4\% (MedPAC, 2013). Between 2010 and 2011 there was another decline in the number of not-for-profits by .8\% and an increase in for-profits by 5\% (MedPAC, 2013). This trend has continued into 2012 as NHPCO (2013b) reports that 32\% of hospices nation-wide are not-for-profit while $63 \%$ are for-profit providers with the remaining $5 \%$ being government owned providers.

It has been hypothesized that this influx of for-profit hospice agencies could have been due to the increase in demand for hospice services (MedPAC, 2009). According to the MedPAC (2009) report, hospice Medicare beneficiary enrollment numbers doubled between 1997 and 2007. MedPAC (2009) speculates that the profitability of having Medicare beneficiaries on hospice services had a significant impact on the increase seen in for-profit providers. Logically, the profit margins are increased when there are patients utilizing services for longer amounts of time. The next section will review patient length of service and ownership status correlation. 


\section{Length of Service and Ownership Status}

One trend that has been observed along with the increase in for-profit hospices is that the average length of service, that is the total number of days a patient receives hospice services, has also increased. In part, this increase was a result of the Balanced Budget Act of 1997 which changed the Medicare policy from limiting coverage to 210 days and allowing unlimited 60-day service availability based on the recertification standards (Hackbarth, 2008). The overall average length of service, regardless of diagnosis increased significantly between 2000 and 2012 from 54 to 72 days (MedPAC, 2013; NHPCO, 2013). More specifically, patients with longer a length of service increased substantially from 141 to 241 days (MedPAC, 2013).

When examining patient diagnostic statistics, the details of the average length of service become clearer. Since 2000, the average length of service for patients with cancer has maintained around the average of 50 days (MedPAC, 2013). However for patients with neurological conditions such as Alzheimer's Dementia, the number of average length of service days increased from 63 in 2000 to 137 in 2011 and accounts for the diagnosis with the largest length of service to date (MedPAC, 2013).

With the majority of hospice patients having a diagnosis other than cancer, hospices are having patients on their services much longer than before. According to NHPCO (2013), this difference in length of service over time could be a result of a combination of factors such as disparities in the access of care, disease trajectory, and timing of referral to hospice services.

Another perspective that has been presented in the literature is that there is a difference in length of service depending on agency ownership status. Patients utilizing 
for-profit hospice agencies have an average of 102 days on hospice services while those serviced under not-for-profit agencies have an average of 69 days of service (MedPAC, 2013). It has been suggested that because of the profitability of reducing average daily costs, for-profit hospices are more likely to admit patients with longer expected lengths of service (Lindrooth, 2007; MedPAC, 2013; Nicosia et al., 2009).

To investigate this hypothesis further, Wachterman et al. (2011) conducted a cross-sectional study from the data of the 2007 National Home and Hospice Care Survey. Their results showed that compared to not-for-profit providers, for-profit hospices tended to have a higher proportion (67\%) of patients with a diagnoses that require less skill needs such as a dementia diagnosis than cancer patients (Wachterman et al., 2011). In addition, the Wachterman et al. (2011) study revealed that for-profit agencies were less likely to have patients with less than 7 days expected length of service and more likely to have patients with length of service longer than 1 year.

This analysis revealed similar results of the Carlson et al. (2004) study that analyzed the 1998 National Home and Hospice Care Survey. The results of the study indicated that patients utilizing for-profit hospice services were less likely to receive high skill services (Carlson et al.,2004). These high skill services, such as continuous care, durable medical equipment as well as supporting medical supplies, are a significant part of the needs that patients have at the end-of-life. The infrequent admission of patients with less skill needs at for-profit hospices could highlight the possible need to examine quality of services being provided to patients under the care of these agencies.

These studies reinforce the claims made by the MedPAC commission (2009; 2013) who indicated that there is a strong correlation between hospice profitability and 
patient length of service. Since the policy does not mandate daily patient visits or differentiate between patient diagnoses, some hospices continue to admit a disproportionate amount of patients that require less need but allot the same financial gains of intensive needs patients due to longer lengths of service availability. Financial incentive can also create more competition between hospices. The following section will compare how marketing practices and access to hospice services are affected by agency ownership status.

\section{Marketing and Access}

When resources are limited, there is a potential to generate a competitive environment in any setting. When it comes to hospice agencies, the competition is based on who can provide the best end-of-life care at the lowest cost. While for-profits have a bottom line of maximizing profit margins to satisfy investors, not-for-profits aim at social missions that are not always reimbursable. Not-for-profits are more likely to engage in charitable activities than for-profits (Aldridge et al., 2014). But these charitable initiatives can be challenging as seeking grant funding opportunities and donations are not as prevalent in for-profit agencies as they are for not-for-profits (Froelich, 2012).

In order to meet the requirements set by stakeholders, for-profits tend to operate using a business mode that allows the maximization of corporate profit. Business strategies are standardized across the agency and include both clinical staff as well as administrative staff (Froelich, 2012). In order to have patients that have longer length of stay potential and less service needs, these agencies tend to influence their patient mix by the referral networks that they have established (Gandhi, 2012). In addition, Froelich (2012) notes that sales representatives utilized under the nomenclature of community 
educators are utilized to directly seek and monitor potential hospice patients. This practice goes hand-in-hand with admitting patients at the early stages of their disease process to maximize the potential profit longer lengths of stay can generate (Froelich, 2012).

Advocates of for-profit hospice providers point out the fact that for-profits tend to have a higher rates of outreach to minority and low-income communities, thereby minimizing the disparities of hospice use seen with these groups (Aldridge et al., 2014). Since for-profit agencies have more access to funding opportunities through capital markets, they are able to reach a larger part of the hospice population by things such as, size of the agency as well as name recognition from longevity of being a provider ("The Debate in Hospice Care, 2008).

Of the patients served by hospice agencies in 2012, only $18 \%$ were non-White recipients (NHPCO, 2013b). Of the total population, NHPCO (2013b) reports about 9\% identify as Black or African American, about 7\% identify as multiracial or other, about 3\% Asian, Hawaiian, or other Pacific Islander, and less than 1\% report being American Indian or Alaskan Native. When examining ethnicity, about $8 \%$ of Hispanic hospice recipients identify as Hispanic or Latino in origin. In their study, Aldridge, et al. (2014) noted that compared to the $48 \%$ of not-for-profit hospices engaging in outreach initiatives, 59\% percent of for-profit hospices reached more of the these populations. Similar results occurred when examining not-for-profit versus for-profit outreach programs geared towards low-income communities, yielding $46 \%$ and $61 \%$ respectively (Aldridge et al., 2014). 
Despite the proposed access benefits, the profit aims and practices of some forprofit hospice providers, there are financial repercussions. The next section of this paper will review the costs of hospice care and the reimbursement policy that all hospices are subjected to if they exceed the funding limitations for the fiscal year.

\section{The Cost of For-Profit Hospice Service}

Patients with very long lengths of service (longer than 180 days) account for over one half of Medicare spending costs in recent years and has caused some concern regarding the reimbursement policy (Evans, 2014). Part of the Hospice Medicare Benefit policy to mitigate excessive Medicare costs is an annual expenditure limit that is enacted is a hospice provider's payments exceed that year's funding limit multiplied by the total number of patients (Ata et al., 2008; MedPAC, 2013). The policy details that if the hospice exceeds that sum of money, set at \$ 26,157.50 for the 2013 fiscal year, the agency must reimburse the excess amount to the benefit program (CMS, 2013; MedPAC, 2013).

Very long lengths of service and the rapid increase in for-profit providers has contributed to more hospices (22\% of for-profit vs. $4 \%$ of not-for-profit) exceeding the set limit in recent years (Aldridge, 2014; CMS, 2014a; MedPAC, 2013). In addition, forprofits have had higher (10\%) disenrollment of live patients than not-for-profits which may suggest that for-profits enroll too many patients with longer length of service and then discharge them to reduce costs (Aldridge et al., 2014). This practice may also be a counteraction to the increase in providers declaring bankruptcy due to the excessive reimbursement amounts during the past few years (Sack, 2007). 
With Medicare costs reaching all-time highs for hospice service availability, financial decisions have been made that have the potential to affect patient care. One aspect of hospice service availability that has been affected is the availability of social service. The next section will review the current state of hospice social work in the United States.

\section{The Current State of Hospice Social Work}

According to the Hospice Medicare policy, psychosocial services provided by hospice include support for mental and emotional well-being for both patient and family which are inclusive of grief support and respite for the caregiver (CMS, 2008). In addition, resource education and linkage are key components in helping patients and families with end-of-life issues such as financial impacts and advanced directive support needs (NHPCO, 2013). Though the aforementioned elements can be examined by several members of the interdisciplinary team, the team social worker is the main professional that addresses these issues due to their expertise in client-centered and culturally competent crisis intervention, counseling and resource linkage (Christ \& Blacker, 2009; NASW, 2005; Reese, 2013; Reese \& Raymer, 2004).

Research scholars have advocated that hospice social service an integral part of assisting in the support needed at the end-of-life (Christ \& Blacker, 2009; Saunders, 2011; Reese, 2013). In addition, the NASW Standards of Social Work Practice for Palliative and End-of-Life Care indicates that social workers aim to address quality-oflife deficiencies from a person-in-environment perspective and advocate for optimal care based on patient and family needs, cultural norms and abilities (Christ \& Blacker, 2009; NASW, 2004). 
More specifically, social worker expertise in facilitation of communication allots for optimal collaboration between all parties actively and potentially involved in care including patients and their respective families, team members, administrators, liaisons, referral sources, as well as community members (Christ and Becker, 2009; Reese and Raymer, 2004). Social workers have the skills to navigate the complex medical and social systems which uniquely help guide patient care in the proper manner (Christ and Becker, 2009).

As the largest groups of mental health professionals involved with hospice care per Christ and Becker (2009), the social work client-centered perspective can foster maximized coping skills in addressing end-of-life issues such as grief, depression, anxiety, and suicide ideation. Hospice social workers can provide psychosocial education to patients and families regarding psychosocial effects of the disease process, daily tasks that can help address quality of life deficits, and community resource availability (NASW, 2004; Christ \& Becker, 2009). In addition, social work competency in advocacy and bioethical issues such as the cessation of artificial feeding and election of non-resuscitation makes their presence on the hospice team all the more warranted (Taylor-Brown et al., 2001).

Reese and Raymer (2004) note in their study that social work involvement in the hospice process was significant related to addressing more patient issues and better team functioning. Better team functioning is thereby correlated with costs and the level of services provided (Reese and Raymer, 2004). The Reese and Raymer (2004) study also revealed that by having more patient issues addressed, costs are reduced by having a 
reduction of additional visits by other team members as issues were effectively being addressed.

However, the medical social workers on hospice teams have either been underutilized for the skill sets they possess and/or over-utilized in the wrong capacities (i.e. performing duties outside of the social work profession) (Reese \& Raymer, 2004). Kulys and Davis (1986) revealed in their study that hospice directors did not view social workers as members of the team that are uniquely qualified to provide psychosocial support. In fact, the only skills that social workers were seen to overwhelmingly be qualified for from the director's perspective were the case management duties of financial counseling and community referrals/linkage. There has been slight improvement in the perception reported by contemporary hospice directors compared to the results revealed in the 1986 Kulys and Davis study. However, according to Reese (2011), an expansion of the Kulys and Davis study showed that the social workers are not engaged in over half of the duties ascribed to them by the profession.

Though one study shows slight improvement in the perceived value of hospice social workers, policies do not reflect this data. As of 2008, individuals employed as hospice social workers only require one year of social work experience in a health care setting and a baccalaureate degree in any social service field (i.e. psychology, sociology, or other field related to social work) (Center for Medicare Advocacy, Inc., 2010).This is a reduction in qualification, creating more vague placement for an already devalued member of the hospice team as in the initial conditions in 1983 mandated that the individual enacting in the hospice social worker role needed to specifically have a degree in social work (Center for Medicare Advocacy, Inc., 2010). Despite social work 
organizations such as NASW and the National Hospice and Palliative Care Organization discouraging the changes, they were finally approved causing National Hospice and Palliative Care Organization, National Council of Hospice and Palliative Professionals, Social Worker Section, Guidelines for Social Work in Hospice were updated to reflect the change (Reese, 2011).

In addition to qualification changes, the focus of Medicare participation in providing hospice services was re-directed from the focus on frequency of visits by hospice team members to the outcome measures of each discipline (Center for Medicare Advocacy, Inc., 2010). The aforementioned decision led to further decline in utilization of social workers on the hospice team (Center for Medicare Advocacy, Inc., 2010). This means that since there was no longer a regulatory mandate of social work visit frequency, the decision to reduce social worker involvement to and "as needed” basis was established to improve cost efficiency despite empirical support of cost effectiveness of the hospice social worker involvement.

Literature reflects that for profit hospices may actually practice this concept of "as needed” social work service availability more commonly than not-for-profit providers. Studies indicate that some for-profit hospice agencies employ less psychosocial staff members who are master’s level medical social workers (Cherin et al., 2010; Gandhi, 2012). This is in spite of the notion that education level can have an impact on skill sets such as critical thinking and problem solving (Cherin et al., 2010). More specifically, hospice social worker qualifications have been shown to be significantly related to agency costs as well as patient outcomes (Reese and Raymer, 2004). 
Some studies indicate that patients receive less social work visits overall when enrolled under for-profit services (Gandhi, 2012; Watcherman et al., 2011). In addition, the Watcherman et al. (2011) study revealed those patients with dementia received half of the amount of social work visits that cancer patients received despite them accounting for the majority of the patient census. This is in contrast with the social workers at the notfor-profit agencies who provided a similar amount of visits regardless of diagnosis (Wachterman et al., 2011).

As indicated by previous studies, there have been variations in service availability by not-for-profit and for-profit hospice providers. More specifically, marketing towards and admission of patients with longer lengths of service on average as well as reduction in the use of medical social workers for patient care at for-profit hospice agencies. This impacts not only funding as indicated by the Medicare hospice policy restrictions, but also the mental, emotional, and social support that patients and families receive or lack thereof.

This study will examine these dynamics further by further analyzing hospice social service availability, delivery in regards to frequency, as well as types of psychosocial services offered by providers. In addition, patient as well as friend and family member utilization of these services will be examined. Lastly, the factors associated with the utilization of hospice psychosocial services will be assessed. The next section will detail this study's design, data sources, and method of analysis.

\section{Research Questions and Hypotheses}

Service availability was identified as whether or not the hospice agency makes specific psychosocial services available to consumers. Specifically, psychosocial service 
availability is identified by the availability of the following services: 1) medical social services, 2) medical social service visit frequency, 3) grief/bereavement counseling, 4) resource referral services, 5) metal health services, 6) respite care services, 7) advanced directive support, 8) ethical issues counseling, 9) interpreter services,10) homemaker services, 11) transportation services, 12) companionship services, 13) Meal on Wheels, and 14) advanced directive support. Service utilization was examined by assessing whether or not a service was utilized by the consumer as not all services are mandatory in order to receive services. Specifically, psychosocial service utilization includes 1) medical social services, 2) bereavement services, 3) resource referral services, 4) mental health services, 5) respite care services, 6) ethical issues counseling services,7) interpreter services, 8) homemaker services, 9) transportation services, 10) Meals on Wheels services, 11) the caregiver wellness program, 12) spiritual services, 13) difficult behavior services, 14) safety training, and/or 15) used abuse/neglect services.

Agency size was identified by the current number of hospice patients using the service. Agency type was identified by whether or not the hospice is freestanding or a part of a hospital. Patient needs were identified as the total activities of daily living (ADLs) that the patient needs help with (i.e. dressing, bathing, transferring, walking, and eating).

Research Question 1: Does hospice agency ownership status predict psychosocial service availability when controlling for agency size and chain status? Hypothesis 1a: When controlling for agency size and chain status, for profit hospices are less likely to have psychosocial services available to hospice patients and families than for other agencies. 
Research Question 2: Does hospice agency ownership status predict psychosocial service utilization by patients and families when controlling for chain status and patient total activities of daily living (ADL) needs?

Hypothesis 2a: When controlling for patient ADL needs as well as agency chain status, patients and families that are under the care of for profit hospices are less likely to utilize psychosocial services than those under the care of not-for-profit and government owned hospice agencies.

Research Question 3: What are the most frequently utilized hospice psychosocial services and what are the factors associated with patient and family utilization of these services? Hypothesis 3a: Patients and families that have higher psychosocial needs (e.g. Medicaid recipients, patients with higher total activities of daily living needs, and underserved individuals) as well as higher need diagnoses (such as cancer) are more likely to utilize hospice psychosocial services than others. Specifically, medical social services such as respite \& resource referral services will be utilized the most. 


\section{CHAPTER III: METHOD}

\section{Research Design}

A retrospective cross-sectional study design of the 2007 National Home and Hospice Care Survey (NCHS, 2007) was used to conduct this study. The study differentiates from the few studies that have utilized this data set because of the unique, comprehensive analysis of hospice psychosocial services within the United States. No other study has examined all of these discipline specific services, the utilization of these services by hospice consumers, nor the characteristics associated with psychosocial service use. This study may provide researchers, clinicians, policy makers and stakeholders with comprehensive knowledge and foundational insight into the state of hospice psychosocial services being offered and utilized nationally.

\section{Ethical Considerations}

This study was deemed exempt by the international review board (IRB) of Florida International University since the data that was used has been de-identified and made publically available.

\section{Data Source}

The data used in this study was derived from the 2007 National Home and Hospice Care Survey (NHHCS) which was conducted by the United States Department of Health and Human Services, Centers for Disease Control and Prevention's National Center for Health Statistics (NCHS, 2007). The parent study was a part of the NHHCS Series that collected nationally represented sample data from home health and hospice agencies along with their respective discharged as well as current patients and families (NCHS, 2007). The surveys were developed to address the data needs of the stakeholders, 
who plan, implement, regulate and set standards for, and/or provide long-term care services (NCHS, 2007).

The study was initially conducted in 1992 and subsequently replicated in 1993, 1994, 1996, 1998, 2007, and 2007 (NCHS, 2007). The 2007 survey was restructured and expanded to include and larger sample sizes, computer-assisted personal interviews (CAPI), and new data items such as psychosocial service delivery and utilization (NCHS, 2007). This study will utilize the most recent data set, the one published from 2007, due to the specific psychosocial variables that were elicited by the data collection tool.

Method of data collection. The investigators of the 2007 NHHCS utilized face-toface interviews with the participating agency staff and directors; however only patient agency records were used to collect the data regarding discharged patients and their respective families and/or friends (NCHS, 2007). Data regarding date of establishment, services, staffing characteristics, programs, and referral sources related to each agency was collected by evaluating agency records (NCHS, 2007). NCHS (2007) reported that the patient data that was evaluated was made available in agency medical records and included items such as demographics, diagnosis, length of service, advanced directives, and services received.

Sampling design. In order to obtain the final sample, a two-stage probability sample design was developed (NCHS, 2007). First, the NCHS investigators selected a universally represented sample of hospice and of home health agencies among the 15,488 available across the United States at that time (NCHS, 2007). This information was cross referenced between three sources: 1) The National Hospice and Palliative Care Organization file of hospices, 2) The Centers for Medicare \& Medicaid Services Provider 
of Services file of home health agencies and hospices, and 3) State licensing lists of home health agencies compiled by a private organization (NCHS, 2007).

Metropolitan statistical area (MSA) and agency type (i.e. hospice, hospice and home health, or only home health) were then established as the first sampling strata (NCHS, 2007). Then agencies were organized by size (based on number of employees), census region, state, county, ZIP code, ownership, and Medicare certification status (NCHS, 2007). Systematic random sampling was utilized with probability proportional to size which yielded a sample of 1,545 agencies (NCHS, 2007).

Of the sample, 84 agencies were not included in the sample either because they merged with other sampled agencies, were out of business, were duplicates of another agency that was a part of the sample, or did not meet the definition used in the survey as a hospice or home care provider (NCHS, 2007). Of that sample, NCHS (2007) reports that 1,036 hospice and home health agencies agreed to participate in the study. A total number of 4,983 discharged hospice patients were sampled, 250 of which were excluded because of any of the following reasons: 1) out of the scope of the study, 2) refusal, 3) no response, 4) record problems, 5) ran out of time, or 6) problems with consent (NCHS, 2007). This resulted in the sample of 4,733 hospice discharge patient cases. For this study, hospice agencies that were also home health agencies were excluded from the data analysis which yielded 359 hospice agencies and 2415 patient cases.

The second phase of data collection of the NCHS (2007) study was conducted during the agency interviews. Patients were randomly selected per agency with up to 10 discharged hospice patients selected by computerized algorithm on the bases of agency director or designee provided census list (NCHS, 2007). NCHS (2007) defined hospice 
discharges as those patients who died or were discharged during the 3-month time frame 4 months prior to the study's agency interview.

Data collection: NCHS (2007) reports that data for the NHHS study was collected from August 2007 until February 2008. The NCHS investigators mailed a selfadministered staffing questionnaire to the agency directors who were subsequently asked to have the forms completed prior to the face-to-face interviews (NCHS, 2007). Interviewers were provided with a five module computer-assisted personal interviewing (CAPI) instrument that was uploaded electronically on laptops (NCHS, 2007). The CAPI modules consisted of Patient Charges and Payments (PA), Patient Sampling (PS), Aide Sampling (AS), Agency Qualifications and Characteristics (AQ), and Patient Health (PH) (NCHS, 2007). Interviewers were able to administer the modules based on designated agency staff availability due to the preliminary screening of eligibility by the AQ module that explored agency characteristics and qualities (NCHS, 2007). According to NCHS (2007) the PH module elicited data regarding hospice agency discharges as indicated in patient medical records. The NHHCS data collection procedures were reported by NCHS (2007) as follows:

"(1) An advance package of NHHCS information, including a letter from the NCHS director, was mailed to the director of each sampled agency, informing him/her of the purpose, content, and authorizing legislation of the survey and that he/she would be contacted by telephone to schedule an appointment. The advance package included letters of support from the National Hospice and Palliative Care Organization and from the National Association for Home Care and Hospice. Also included in the package was a copy of an NCHS report- The Use of Computerized Medical Reports in Home Health and Hospice Agencies: United States, 2000-to illustrate how the survey data can be used to present important findings in the industry. 
(2) After the package was mailed, the interviewer telephoned the sampled agency to speak to the director, explain the survey in further detail, address any questions or concerns about NHHCS, and schedule an in-person interview with the director. (3) After the interviewer successfully scheduled an interview, a confirmation package was mailed to the director. This package included a confirmation letter with details about agency information the interviewer would need to complete the interview, in addition to the self-administered staffing questionnaire that the director was expected to complete by the day of the agency interview.

(4) At the in-person agency interview, the interviewer collected the completed staffing questionnaire and administered the AQ module of CAPI. Provided the agency was eligible to participate in the survey, the interviewer sampled up to 10 current home health patients/hospice discharges using the PS module of CAPI. In mixed agencies, a combination of up to 10 current home health patients and hospice discharges were sampled, usually 5 of each; if 5 of either group was not available, the interviewer sampled more from the group that had more than 5 on the census list. The interviewer completed the sampling exercise by cleaning (e.g., identifying and removing duplicate names on a list of current home health patients) and numbering the census lists and entering the total number of current home health patients and/or hospice discharges into CAPI. Subsequently, CAPI randomly selected 10 numbers based on the total number of current patients/hospice discharges that were entered into the computer algorithm. The sampled patients/discharges were those corresponding to the randomly generated numbers in the census list.

(5) The interviewer met with designated staffs that were familiar with the sampled patients/discharges and their care and collected information on the survey items in the $\mathrm{PH}$ and PA modules for each sampled patient/discharge. The respondents referred to patient medical records, administrative records, and medication administration records to answer the survey items. No patients or families/friends were interviewed directly.” 
Researchers reviewed the data to ensure accuracy, consistency, thoroughness, as well as logical responses were provided (NCHS, 2007). The International Classification of Diseases, 9th Revision, Clinical Modification was used to code the resulting medical information elicited from the PH module. The NCHS (2007) authors note that for each case, one primary admission diagnosis and the hospice discharge diagnosis was collected with up to five procedures per sampled case.

Data management. The data for the 2007 NHHCS is maintained by the Interuniversity Consortium for Political and Social Research (ICPHR) National Archive of Computerized Data on Aging (NACDA) (NCHS, 2007). Data was accessed through the ICPHR website due to required membership privileges. Patient and agency data was deidentified and coded with identification numbers to maintain confidentiality.

\section{Data Analysis}

The Statistical Package for Social Sciences (SPSS) 19 statistical software (IBM SPSS Statistics, 2010) was used to run the statistical analysis for this study. To evaluate the types of patients and families that utilize hospice psychosocial services, chi-square tests were utilized. Hierarchal linear as well as hierarchical logistic regressions were used to assess the likelihood of psychosocial service availability as well as patient and family psychosocial service utilization based of hospice agency ownership status. These models were selected due to the outcomes being binary as well as the need to control for cofounding variables. A separate analysis was conducted for each variable.

\section{Selected Data Variables}

The independent variable for research question number one was hospice agency ownership status and the dependent variables were as follows: 1) medical social services, 2) 
grief/bereavement counseling, 3) resource referral services, 4) metal health services, 5) respite care services, 6) assessment of patient advanced directive status, 7) provision of advanced directive information, 8) provision of advanced directive forms, 9) educating the patient about advanced directives, 10) only providing advanced directive information when asked, 11) having restrictions on implementing advanced directives, and 12) ethical issues counseling. The covariates for research question number one were 1) agency size and 2) agency chain status.

The independent variable for research question number two was ownership status. The dependent variables were as follows: 1) used medical social services, 2) medical social service visit frequency, 3) used resource referral services, 4) used mental health services, 5) used respite care services, 6) used ethical issues counseling services, and 7) used bereavement services. The covariates for research question number two were 1) agency chain status and 2) patient total activities of daily living (ADL) needs.

Hospice agency chain status, agency size and patient ADL needs were treated as covariates as literature suggest that the volume of an agency as well as patient care needs can have an impact on the outcomes observed in healthcare settings (Halm, 2002; Saxena, Car, Eldred, Soljak, \& Majeed, 2007; Wharton, Keely, \& Grines, 2005). Multiple imputations were used to account for missing survey response data.

The independent variables for research question number three were 1) primary diagnosis, 2) cognitive status, 3) patient total ADL needs, 4) level of care, 5) length of service (days on hospice), 6) payer source, 7) age at discharge, 8) race (including American Indian, Asian, Black/African-American, Pacific Islander, or White), 9) ethnicity (Hispanic or non-Hispanic), 10) gender, 11) marital status, 12) veteran status, 
13) caregiver status, 14) identification of the patient caregiver, 15) household membership, 16) location of service at the beginning of hospice, and 17) location of service at the end of hospice.

The dependent variables were the following: 1) used medical social services, 2) medical social service visit frequency, 3) used resource referral services, 4) used mental health services, 5) used respite care services, 6) used ethical issues counseling services, 7) advanced directive status and psychosocial service utilization, 8) used interpreter services, 9) used homemaker services, 10) used transportation services, and 11) used Meals on Wheels services. The following variables were also examined as services that can provide patients and families with additional psychosocial benefits while under hospice care: 1) pastoral care services, 2) volunteer services, 3) companionship services, 4) homemaker services, and 5) complimentary alternative medicine (CAM) (including acupuncture, aromatherapy, art therapy, message, music therapy, pet therapy, therapeutic touch, and/or transcutaneous electrical nerve stimulation) (Demmer, 2004; Nicholas, Sullivan, Ide, Shreffler-Grant, \& Weinert, 2005; Reese, 2013 ).

For variables specific to caregiver services, the dependent variables will be 1) used bereavement services, 2) used caregiver health and wellness services, 3) used spiritual care services, 4) used dealing with difficult behavior services, 5) used safety training services, 6) used suspected abuse or neglect services, and 7) used resource referral information services.

Agency demographic variables were 1) average patient census, 2) amount of years that the hospice agency has been in operation, 3) amount that are Joint Commission for Accreditation of Healthcare Organizations (JCAHO), 4) availability of a social worker on 
staff or contracted with the agency, 5) availability of medical social services, 6)

availability of mental health services, 7) availability of grief and bereavement services, 8)

availability of ethical issues counseling, 9) availability of resource referral services, 10)

availability of respite care services, 11) availability of transportation services, 12)

availability of Meals on Wheels services., 13) availability of interpreter services, 14)

availability of patient materials translated into languages common to the service area, 15)

multilingual staff, and 16) availability of cultural competence training. 


\section{CHAPTER IV: RESULTS}

\section{Descriptive Statistics}

Agency demographics. Of the data that was used in this study, 95 were for profit and 264 were classified as other (either private not-for-profit or government owned). For profit agencies had an average of 75 patients while private not-for-profit and government hospice agencies had an average of 70 patients. For profit hospice agencies were established within 8 years of when the parent study was conducted between 2006 and 2007 while other agencies had been established within about 18 years of the parent study. Results indicated that 7 for profit agencies were Joint Commission for Accreditation of Healthcare Organizations (JCAHO) certified and 87 of the other hospice agency types were certified.

According to the results, $85 \%$ of for profit hospice agencies had social workers on staff while $75 \%$ of other hospices had a social worker on staff. Of the for profit agencies, 99\% had medical social services available while $92 \%$ of other agencies had this service available. Among for profit agencies, 41\% had mental health services available while $47 \%$ of the other agencies had this service available. Grief and bereavement services were made available by $97 \%$ of all hospice agencies. Results indicated that $68 \%$ of for profit hospices had ethical issue counseling services available and $75 \%$ of the other agencies had this service available. Results indicated that $80 \%$ of for profit agencies made referral services available and $85 \%$ of other agencies had resource referral services available. (see Figures 1and 2) 
Figure 1. Sampled Hospice Agencies

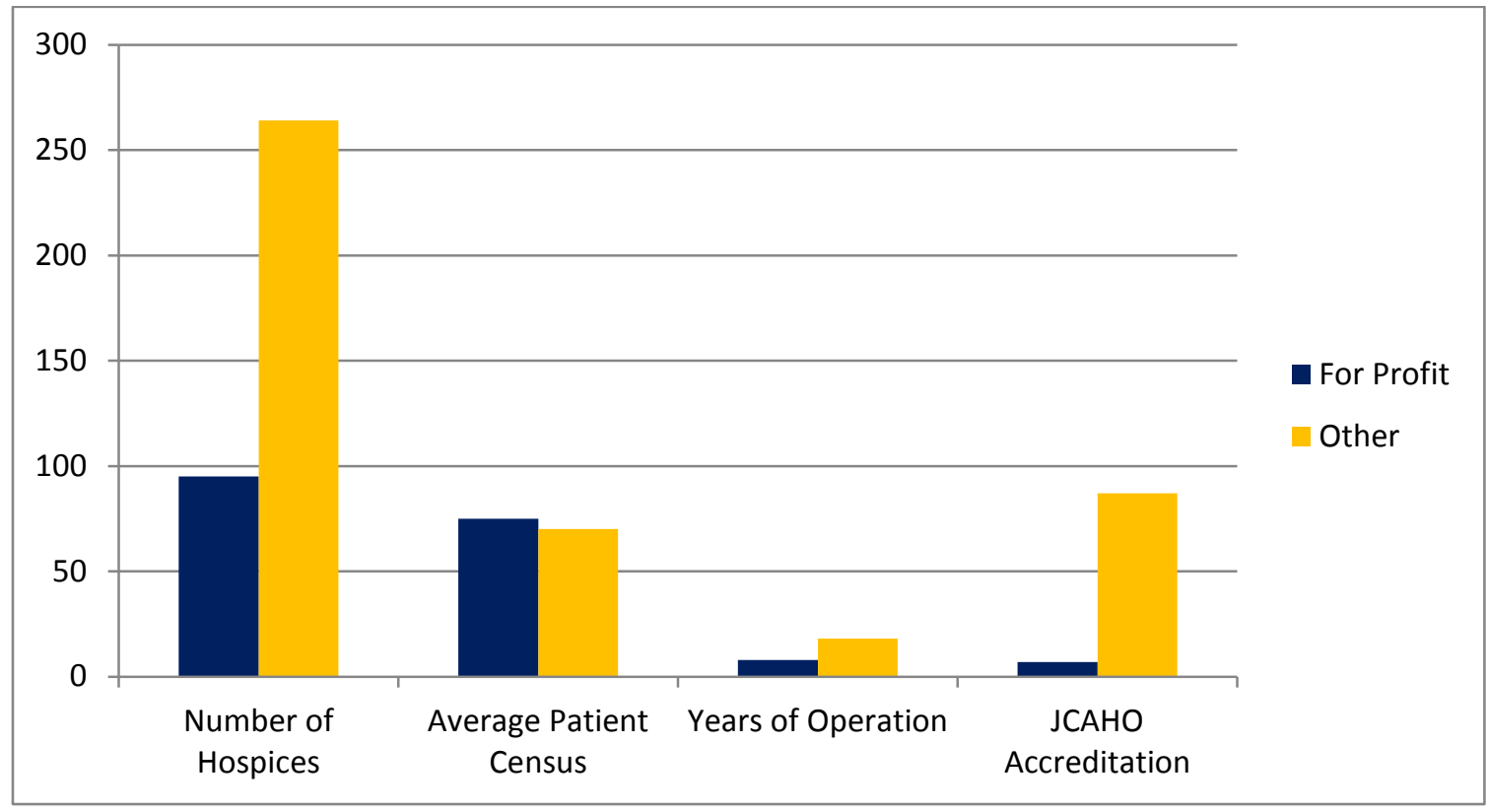

Figure 2. Hospice Medical Social Work Service Availability

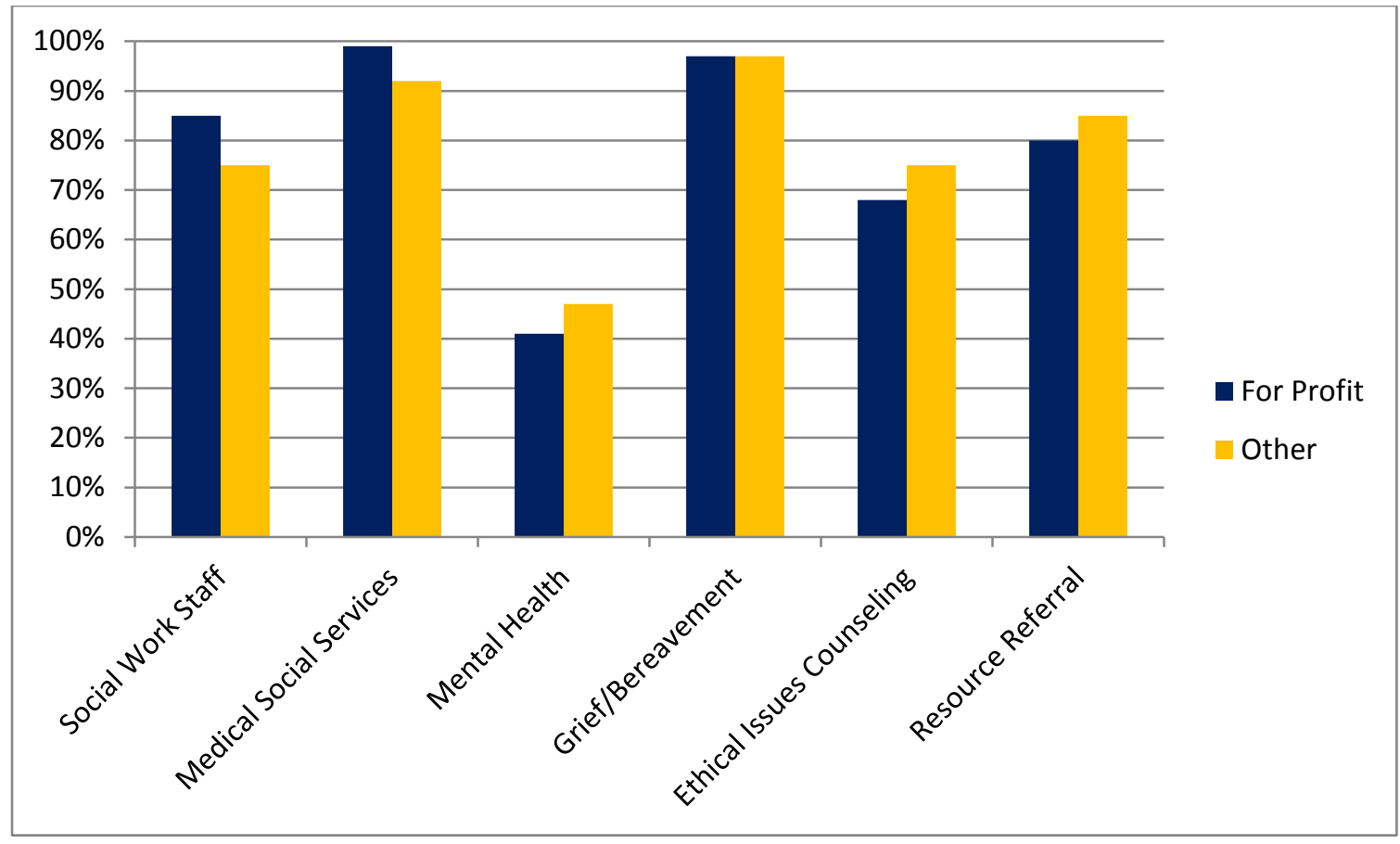


Among all of the hospice agencies, 95\% had respite care available. According to the results, $48 \%$ of for profits had transportation services available and $60 \%$ of other providers had this service available. $40 \%$ of for profit hospices had Meals on Wheels services available while $28 \%$ of other agencies had Meals on Wheels services. Interpreter services were made available by $75 \%$ of for profit hospices and $81 \%$ of other hospices provided this service. Results indicated that $60 \%$ of for profit agencies offered patientrelated materials that were translated into commonly represented languages within their respective community while $65 \%$ of other hospice agencies had these materials available. Of all hospice agencies, 47\% had multi-lingual staff available. Provision of cultural competency training was made available by $97 \%$ of for profit agencies and $95 \%$ of other hospice providers. (see Figures 3 and 4)

Figure 3. Hospice Respite, Transportation, \& Meals on Wheels Service Availability

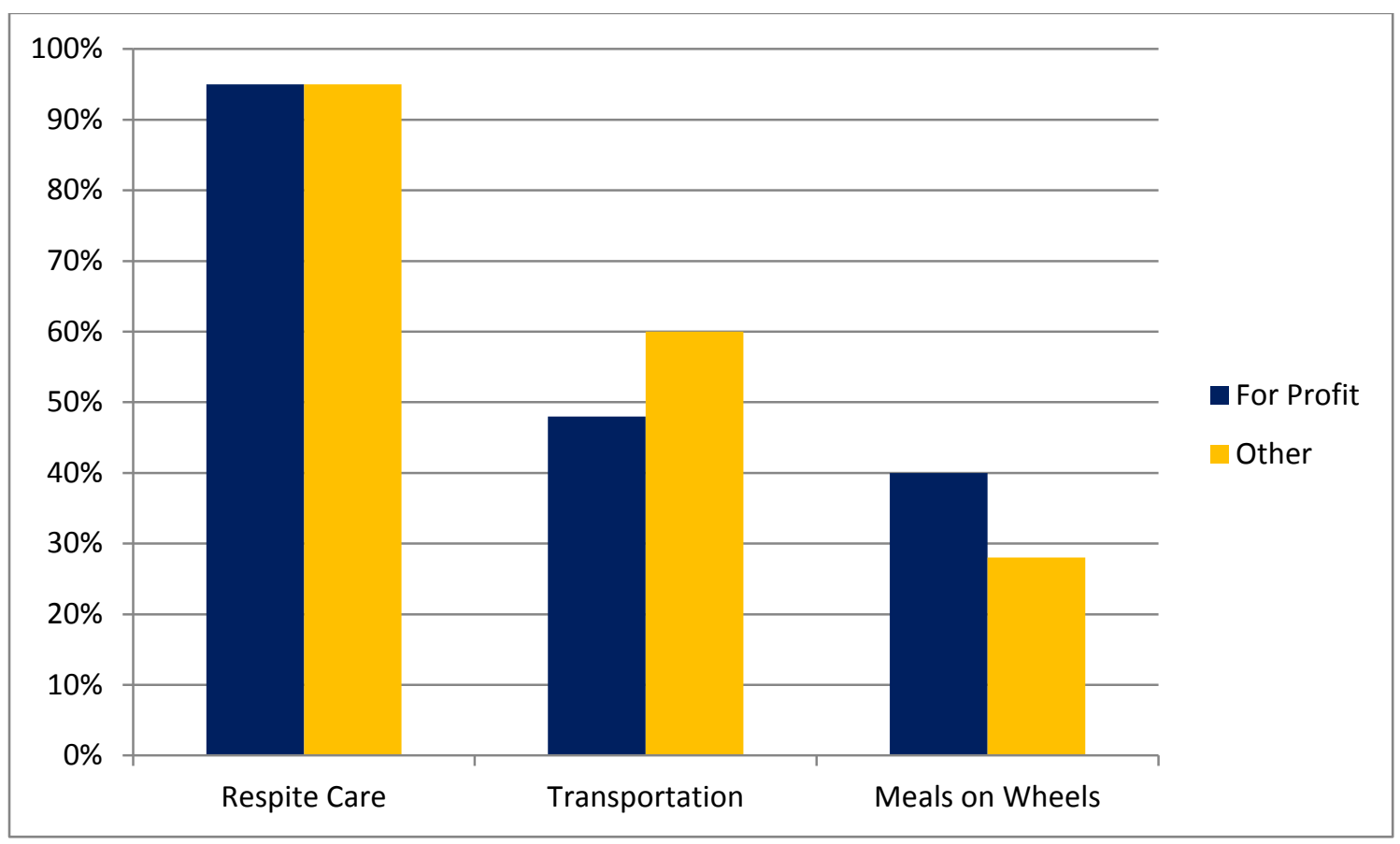


Figure 4. Hospice Multicultural Service Availability

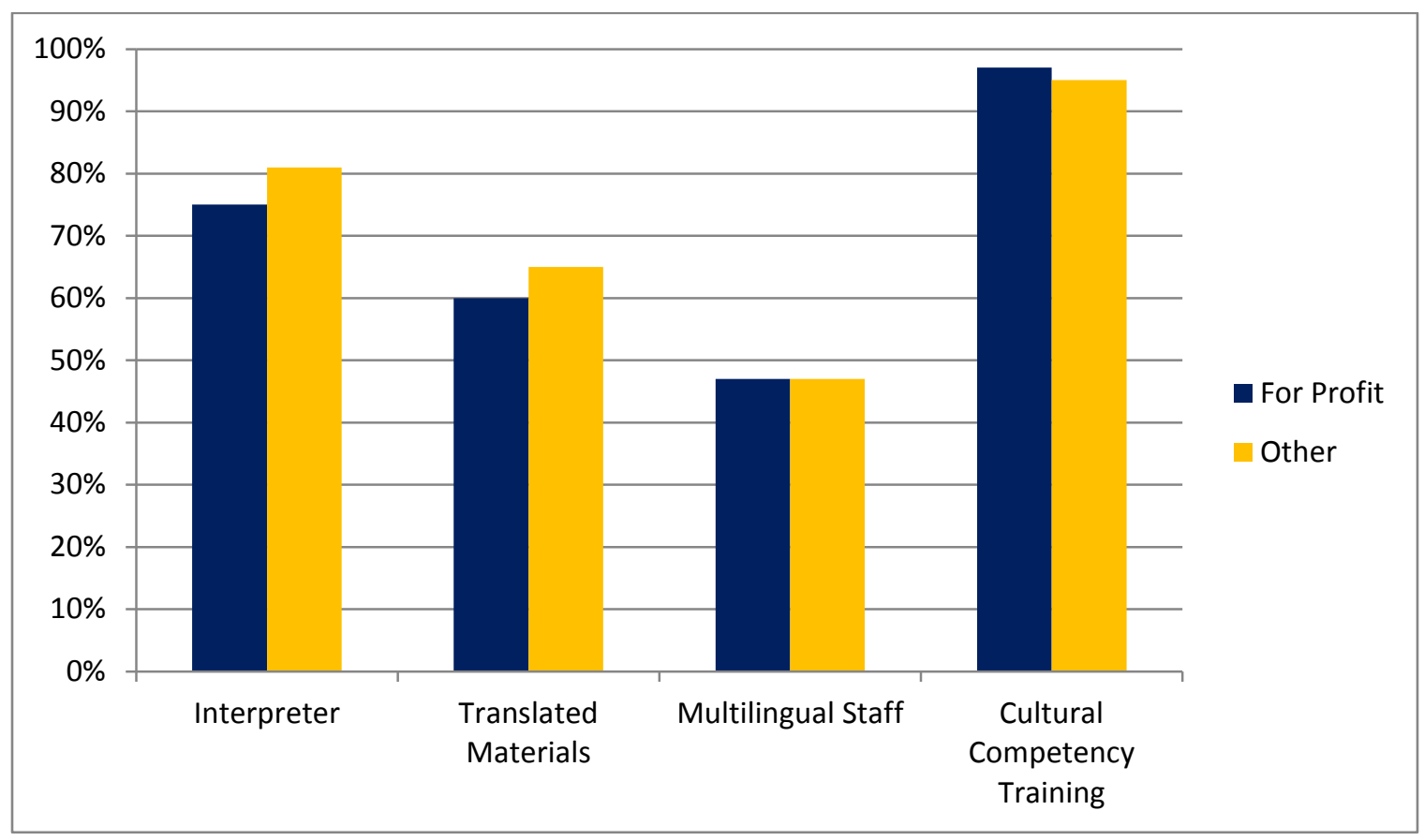

According to the descriptive statistics, pastoral care services were made available by $99 \%$ of for hospice agencies and $97 \%$ of other hospice providers had this service available. Similarly, 99\% of for profits had volunteer services available and $97 \%$ of others had volunteer services available. Among for profit hospices, 59\% had companion services and $65 \%$ of others made this service available to patients. Results revealed that $74 \%$ of for profits had homemaker services available and $73 \%$ of others had homemaker services. CAM services were available at $44 \%$ of for profit hospices and at $53 \%$ of other hospices. (see Figure 5) 
Figure 5. Pastoral, Volunteer, \& Optional Supportive Care Hospice Service Availability

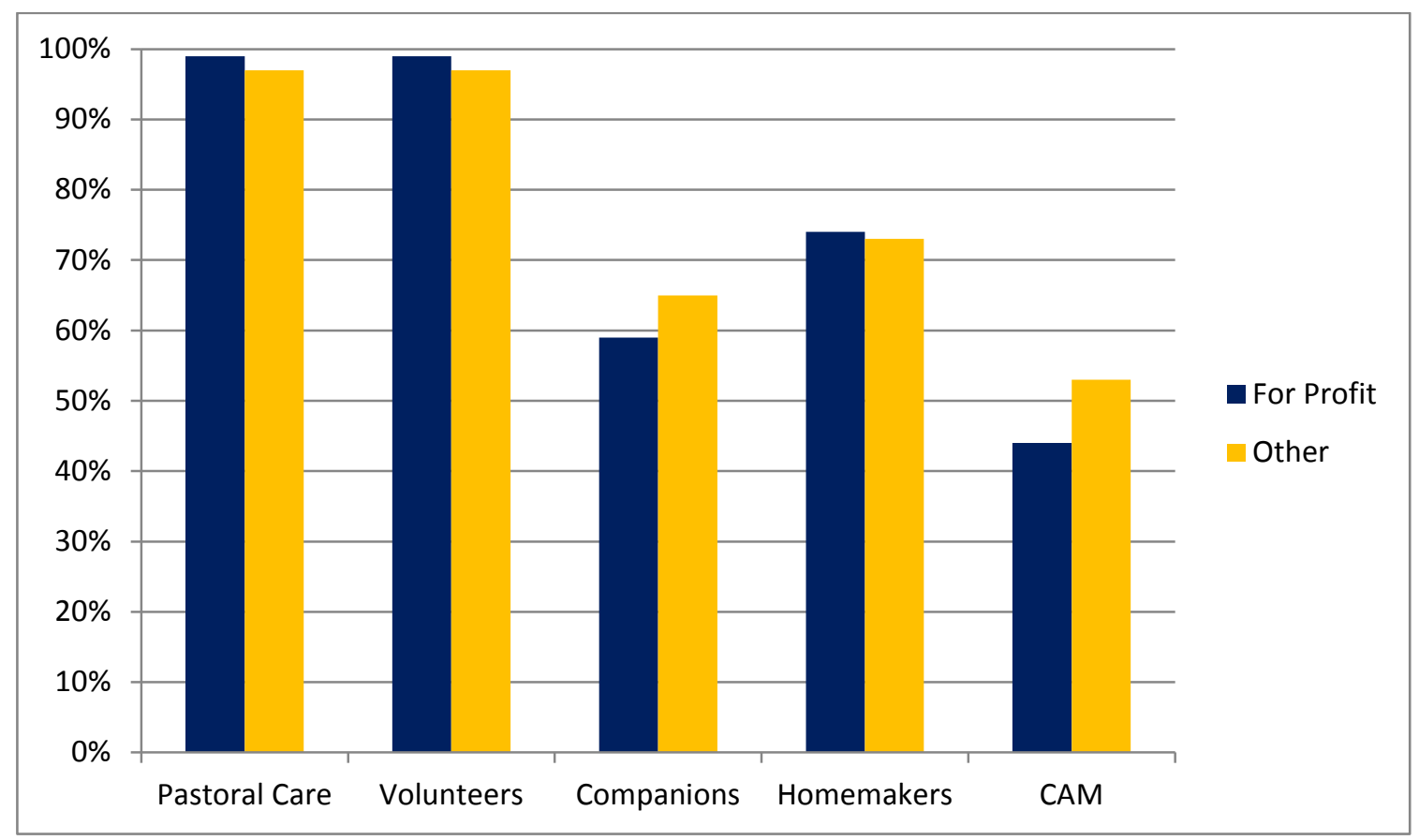

Patient demographics. There were at total of 2415 discharged patient cases that were analyzed in this study. Descriptive statistics show that $29 \%$ of these patients were under hospice care provided by for profit agencies and $71 \%$ were at either private not-forprofit hospices or government owned hospice agencies. For profit agencies had more patients with diagnosis of tracheal, bronchial, or lung cancer, heart failure, or late effects of cerebrovascular disease (representing $25 \%$ of the diagnoses cumulatively). At government owned or not-for-profit hospice providers, most patients were diagnosed with tracheal, bronchial, or lung cancer (11\%), heart failure (6\%), and unspecified chronic airway obstruction (6\%). Most hospice patients had no cognitive impairment (30\% at for profits and 38\% at others). Most hospice patients had 4 of 5 total ADL needs (29\% had 5 total ADL needs at for profit agencies and 24\% had 4 total ADL needs at other hospice agencies. Routine homecare patients represented most hospice patients 
(36\% at for profit agencies and $57 \%$ at other agencies) and had an average of $48-50$ days on hospice care (see Figures 6-15)

Figure 6.Total Patient Census

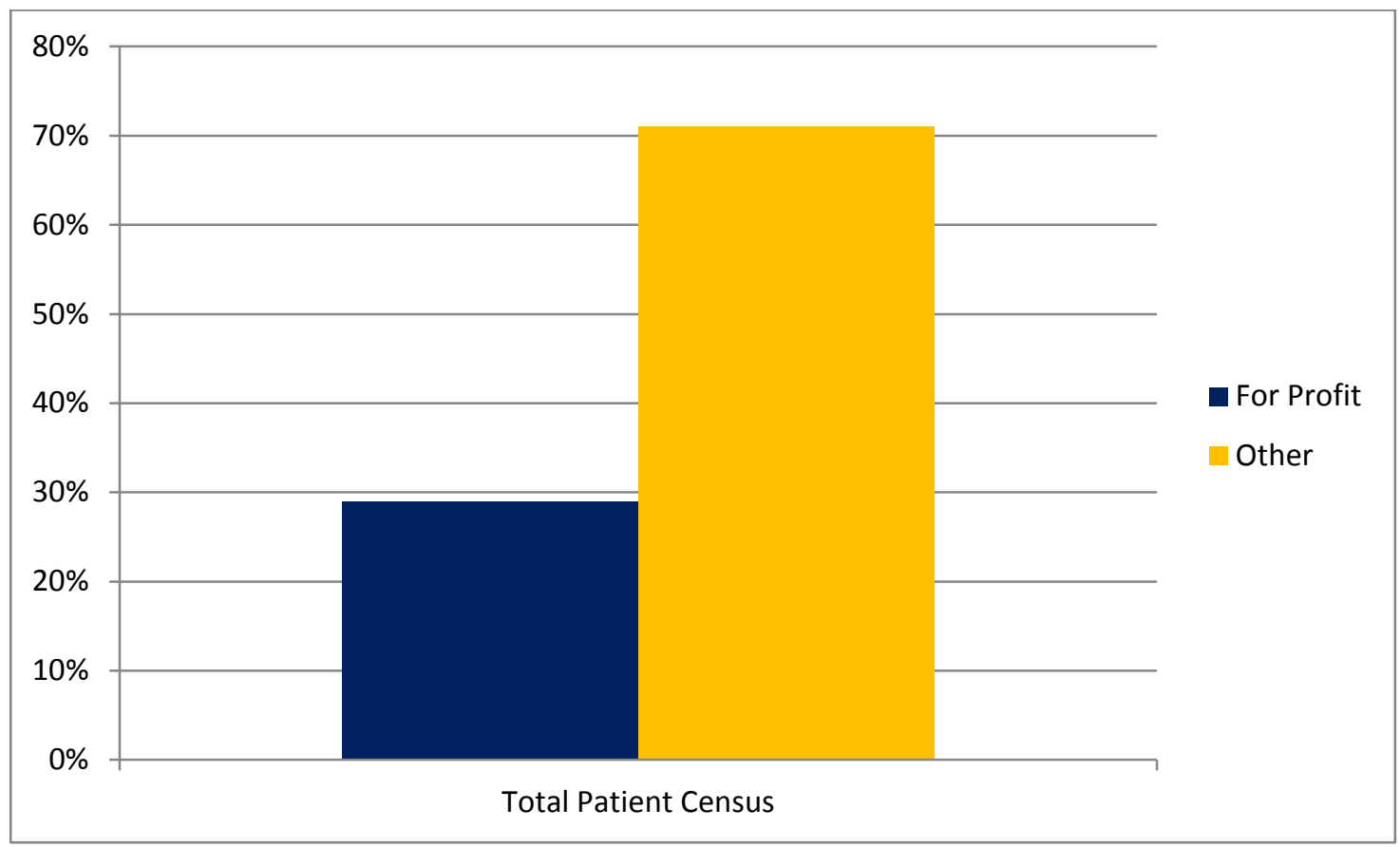

Figure 7. Most Common Patient Diagnoses at For Profit Hospices

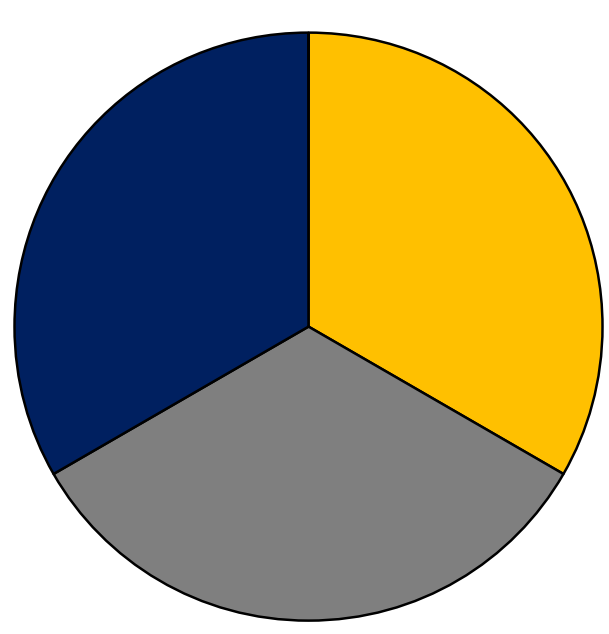

$\square$ Tracheal, Bronchial or Lung Cancer $\square$ Heart Failure $\square$ Late Effects of Stroke 
Figure 8. Most Common Patient Diagnoses at Not-for Profit or Government Owned Hospices

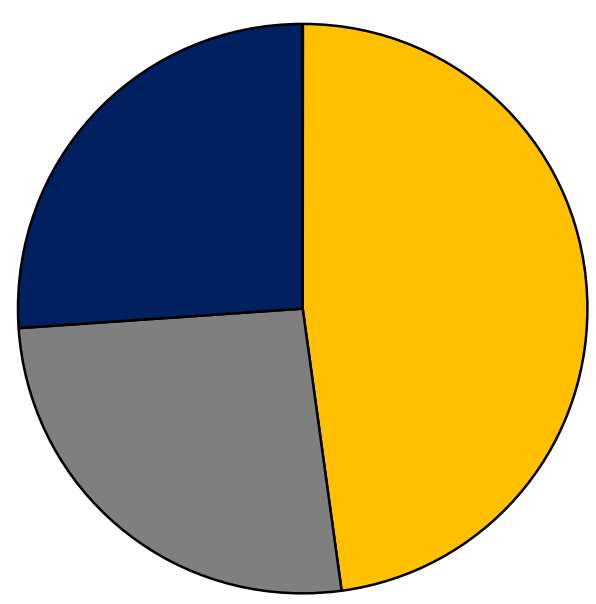

Tracheal, Bronchial or Lung Cancer

$\square$ Heart Failure

- Unspecified Chronic Airway Obstruction

Figure 9. Average Patient Cognitive Status at For Profit Hospices

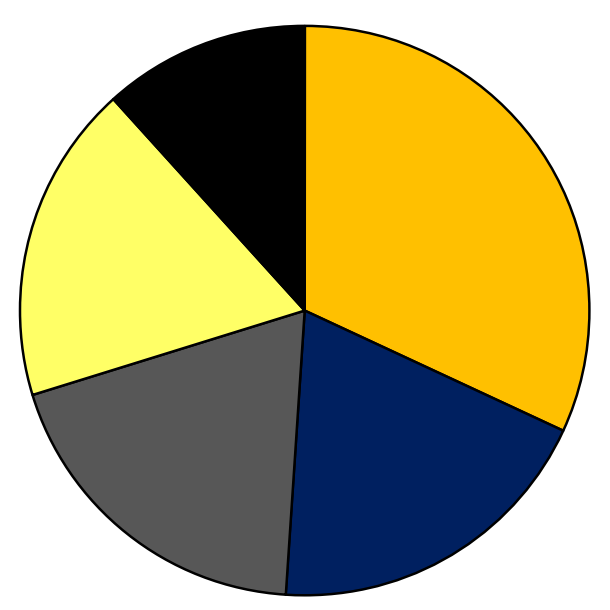

$\square$ No Cognitive Impairment

Needs Some Assistance

- Severa Cognitive Impairment
Needs Occational Reminders

$\square$ Needs a Great Deal of Assistance 
Figure 10. Average Patient Cognitive Status at Not-for-Profit of Government Owned Hospices

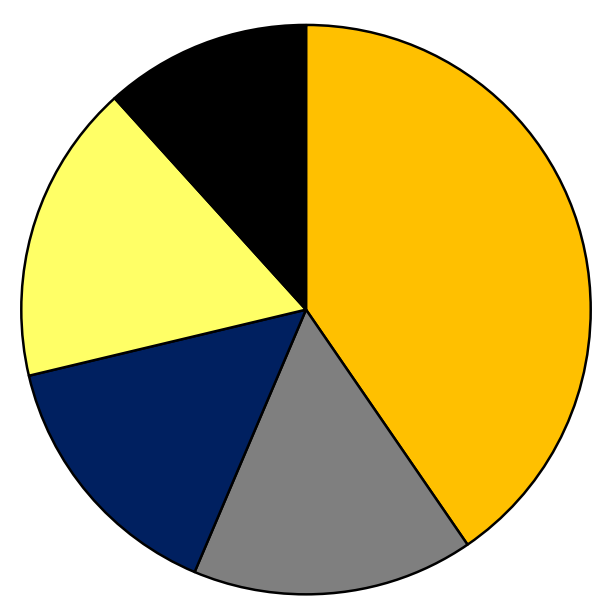

$\square$ No Cognitive Impairment

Needs Some Assistance

- Severa Cognitive Impairment $\square$ Needs Occational Reminders

$\square$ Needs a Great Deal of Assistance

Figure 11. Average Total Patient ADL Needs at For Profit Hospices

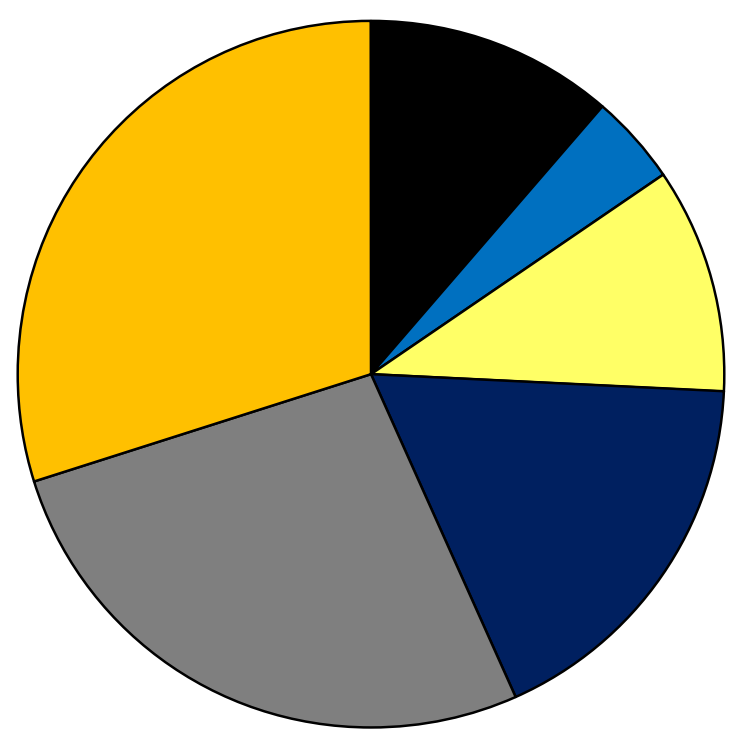

Zero $\square$ One $\square$ Two $\square$ Three $\square$ Four $\square$ Five 
Figure 12. Average Total Patient ADL Needs at Not-for Profit of Government Owned Hospices

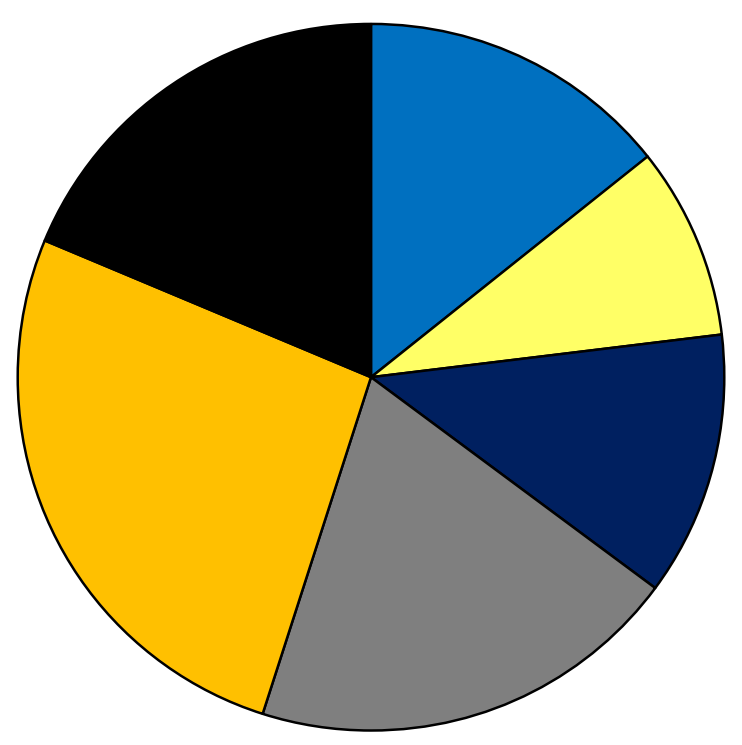

$\square$ Zero $\square$ One $\square$ Two $\square$ Three $\square$ Four $\square$ Five

Figure 13. Average Amount of Hospice Patients with Advanced Directives

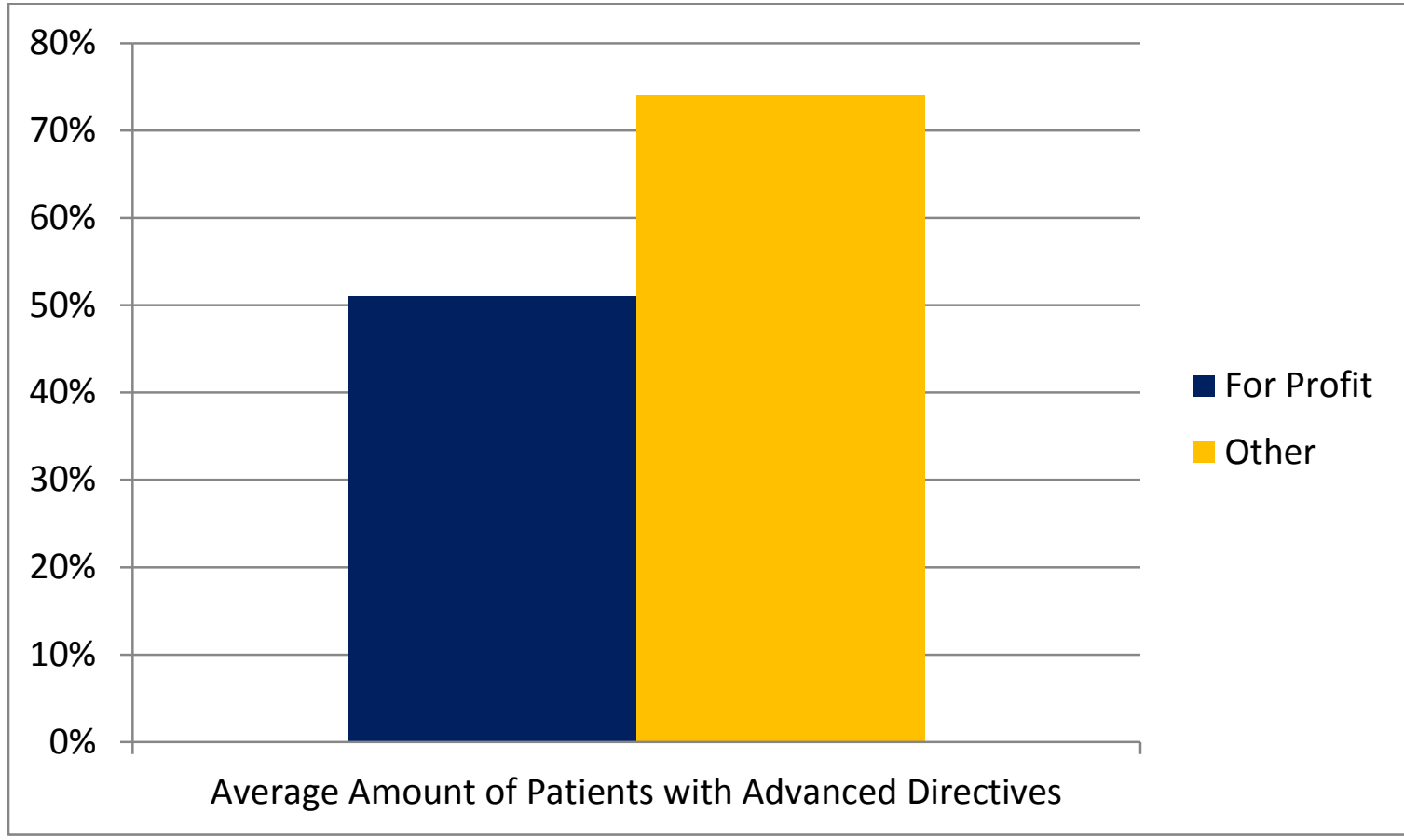


Figure 14: Average Hospice Patient Care Status

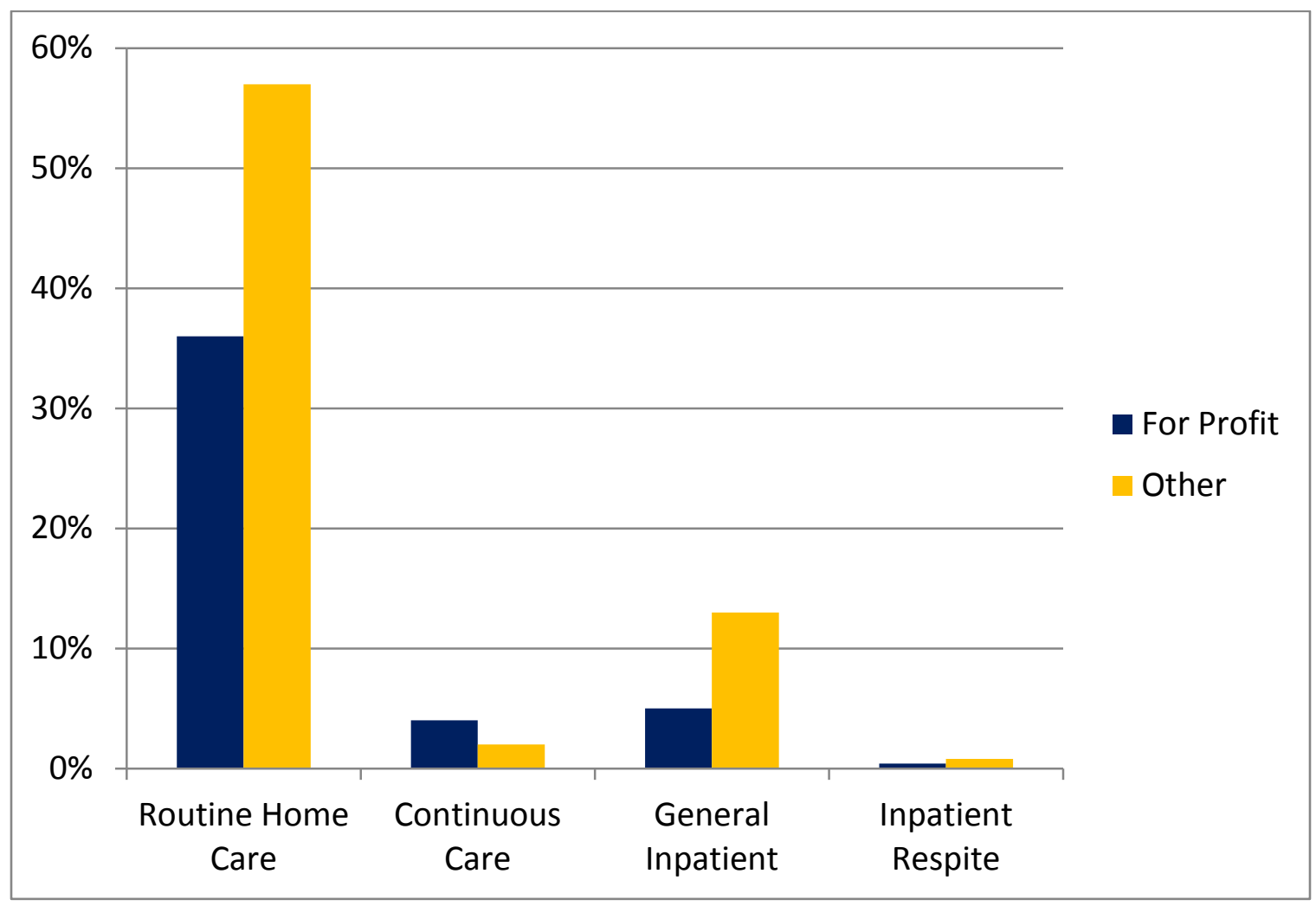

Figure 15. Average Patient Length of Service at Hospice Agencies

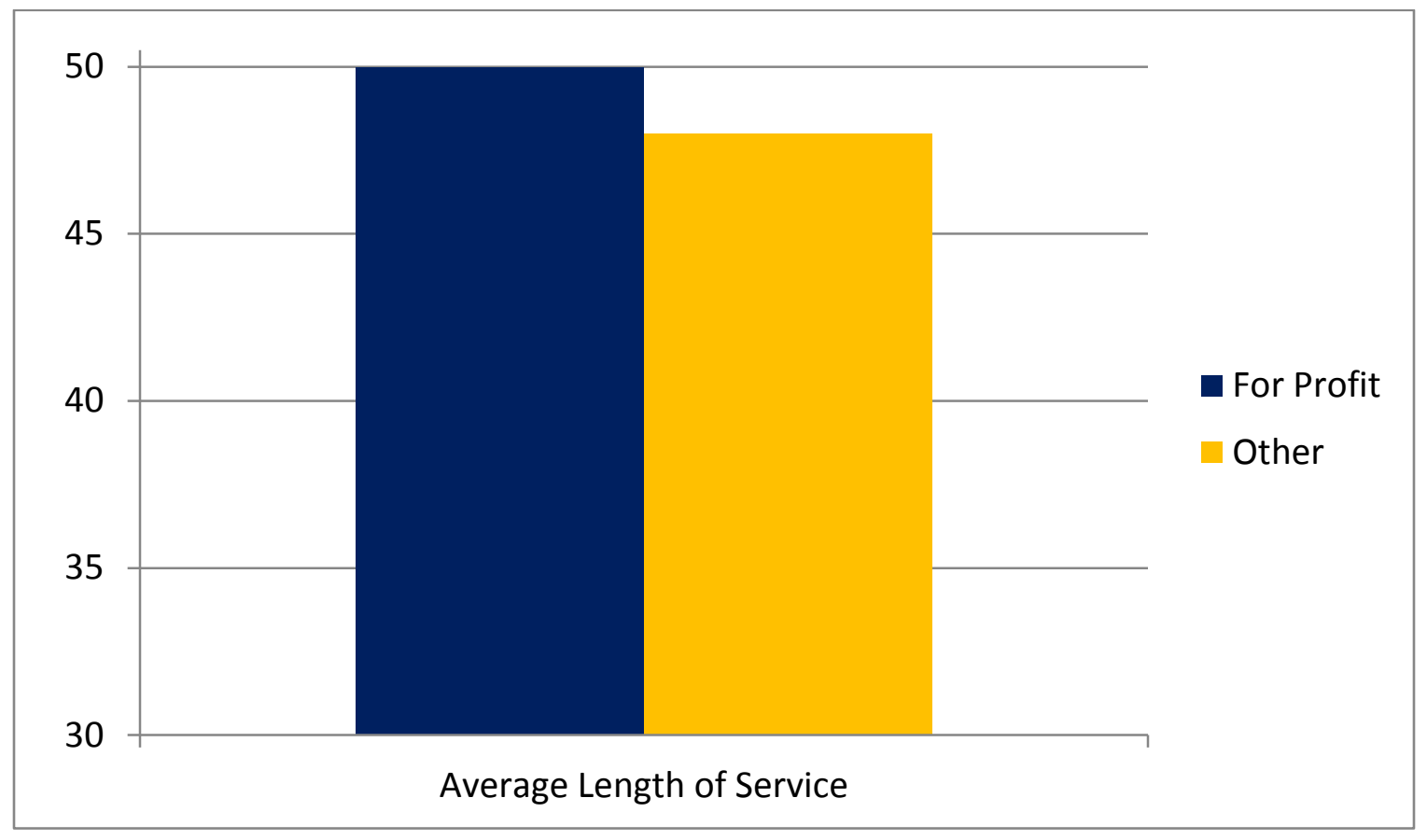


The average age of patients at for profit hospices was 80 while those at other providers had the average age of 75 years old. As it pertains to gender, $40 \%$ of for profit patients were male and 60\% were female. At not-for-profit of government owned hospices, $45 \%$ of patients were male and $55 \%$ were female. The majority of patients were non-veterans ( $8 \%$ at for profit agencies and 10\% at others). Most hospice patients were widowed (37\% were widowed at for hospice agencies) or married (42\% were married at other hospices). Most hospice patients racially identified as White (84\% at for hospices and $93 \%$ at others). More specifically, $74 \%$ of patients at for profit hospices and $88 \%$ at other providers identified ethnically as White, non-Hispanic. (see Figures 16- 21)

Figure 16. Average Age of Hospice Patients

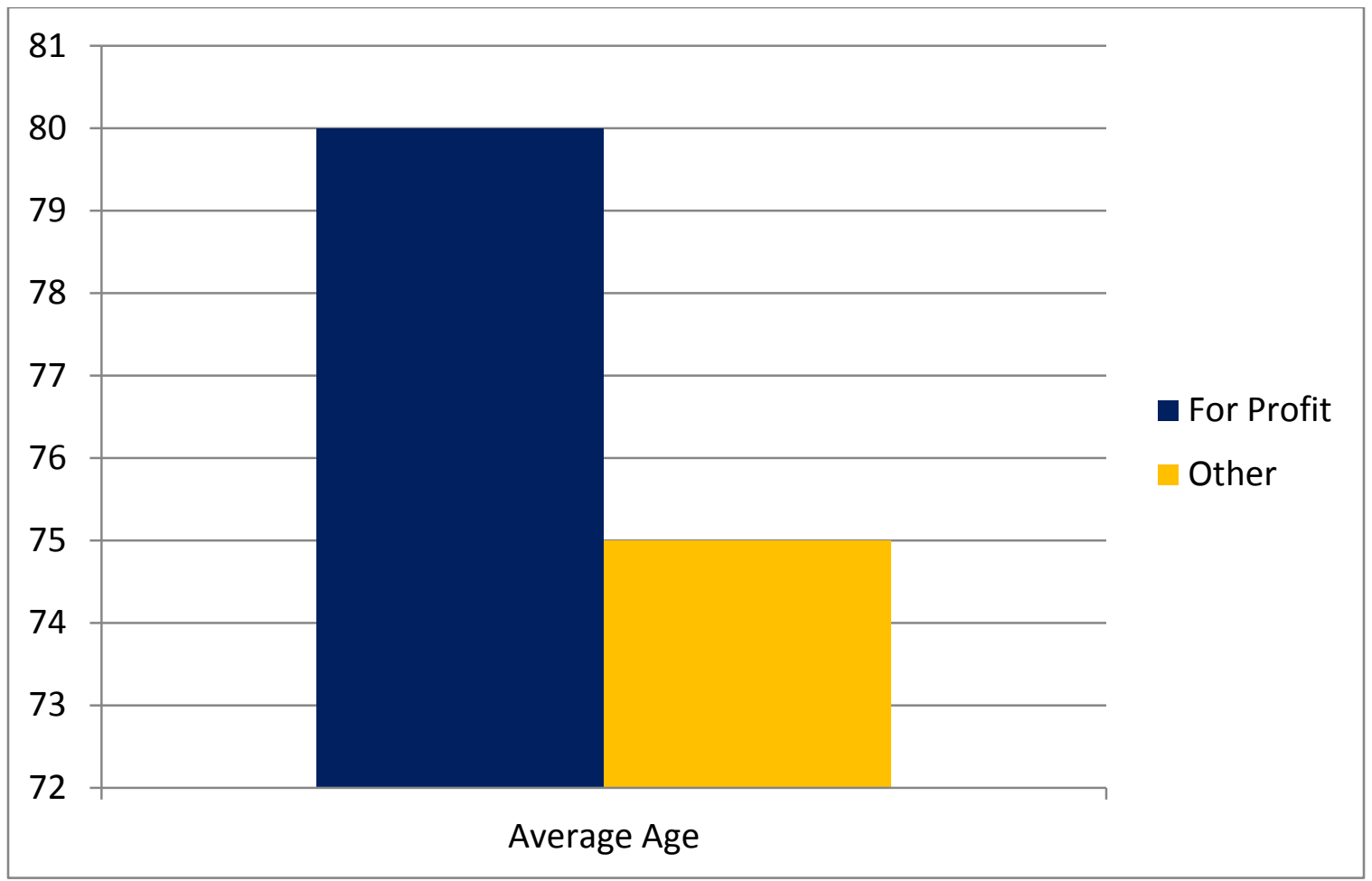


Figure 17. Average Gender and Veteran Status of Hospice Patients

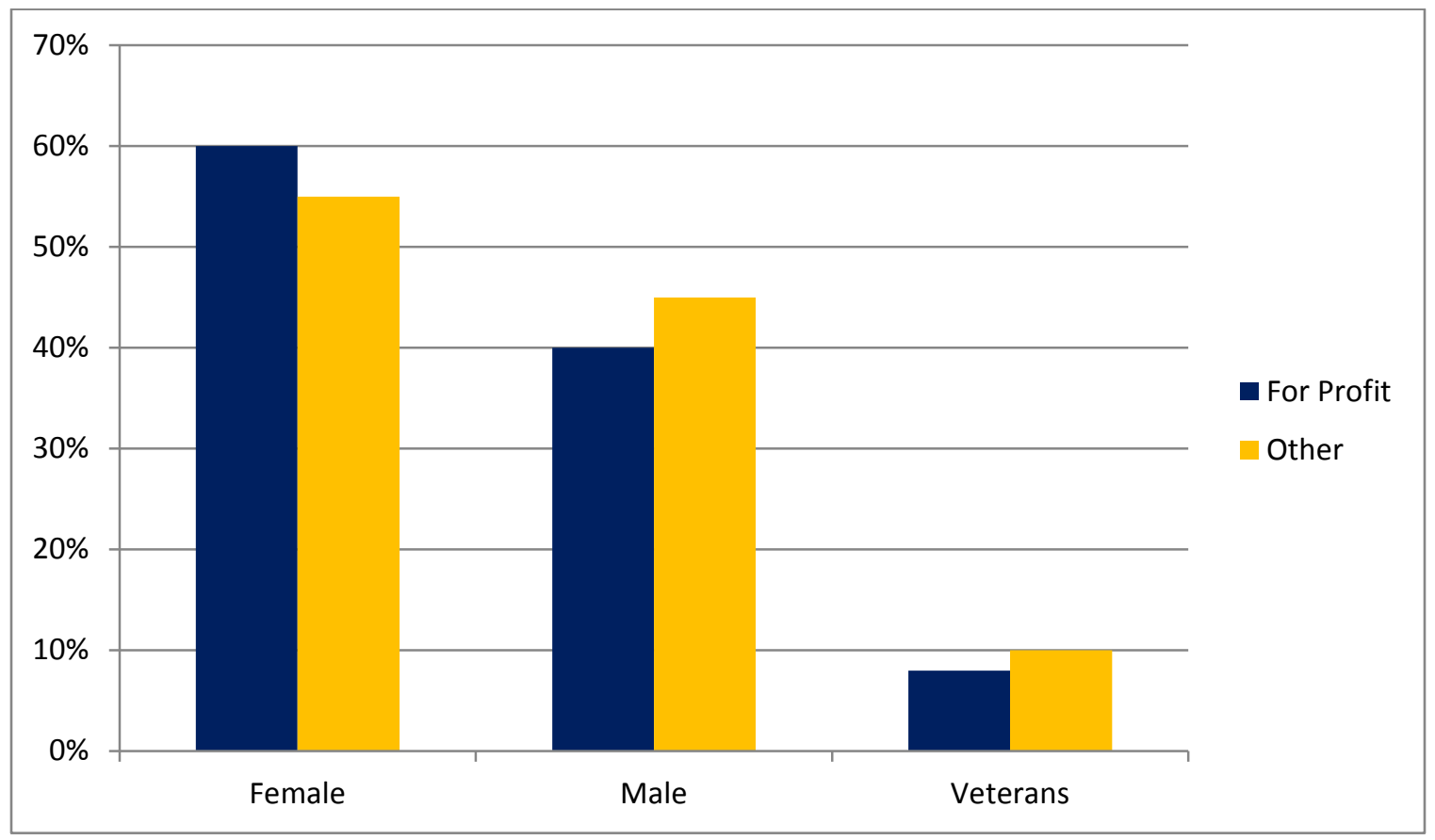

Figure 18. Average Patient Marital Status at For Profit Hospices

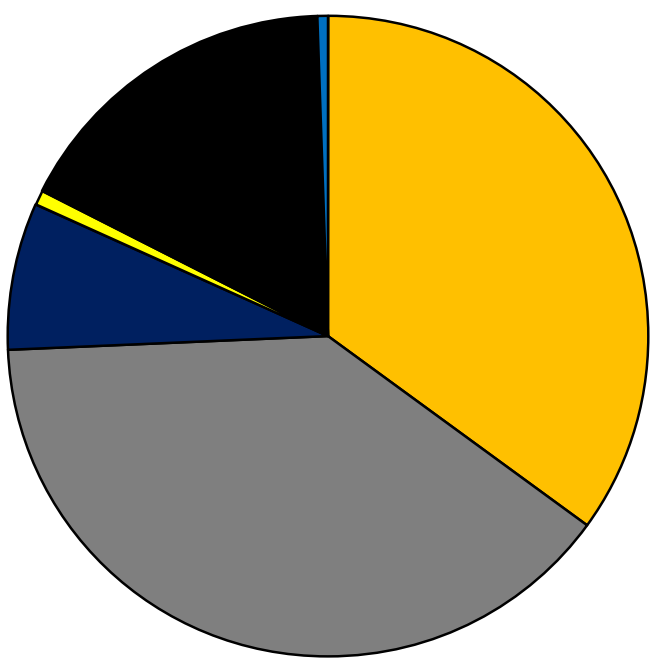

$\square$ Married

$\square$ Widowed

Divorced

$\square$ Seperated

Never Married

$\square$ Living with a Partner 
Figure 19. Average Patient Marital Status at Not-for-Profit and Government Owned Hospices

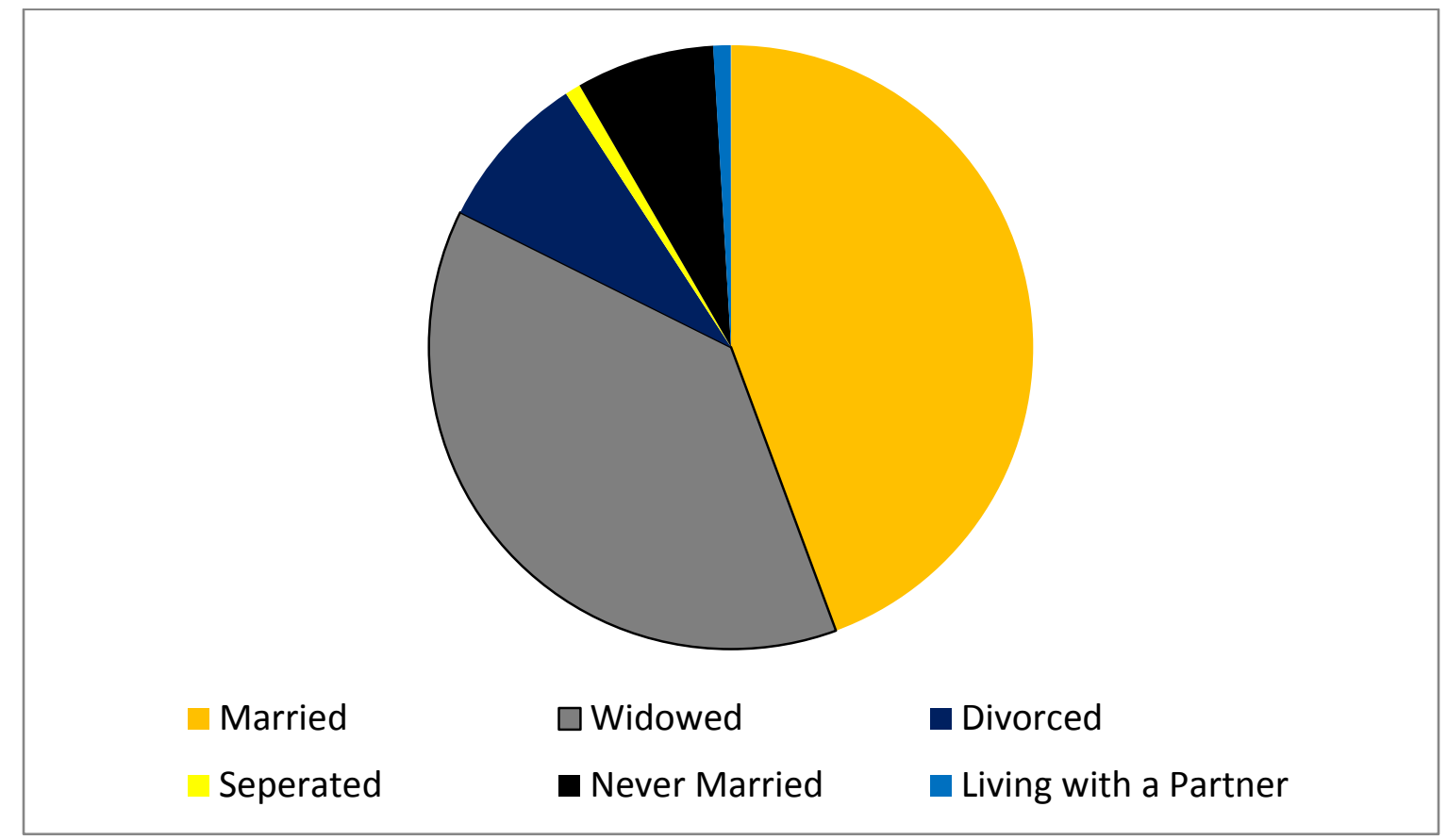

Figure 20. Racial Demographics of Hospice Patients

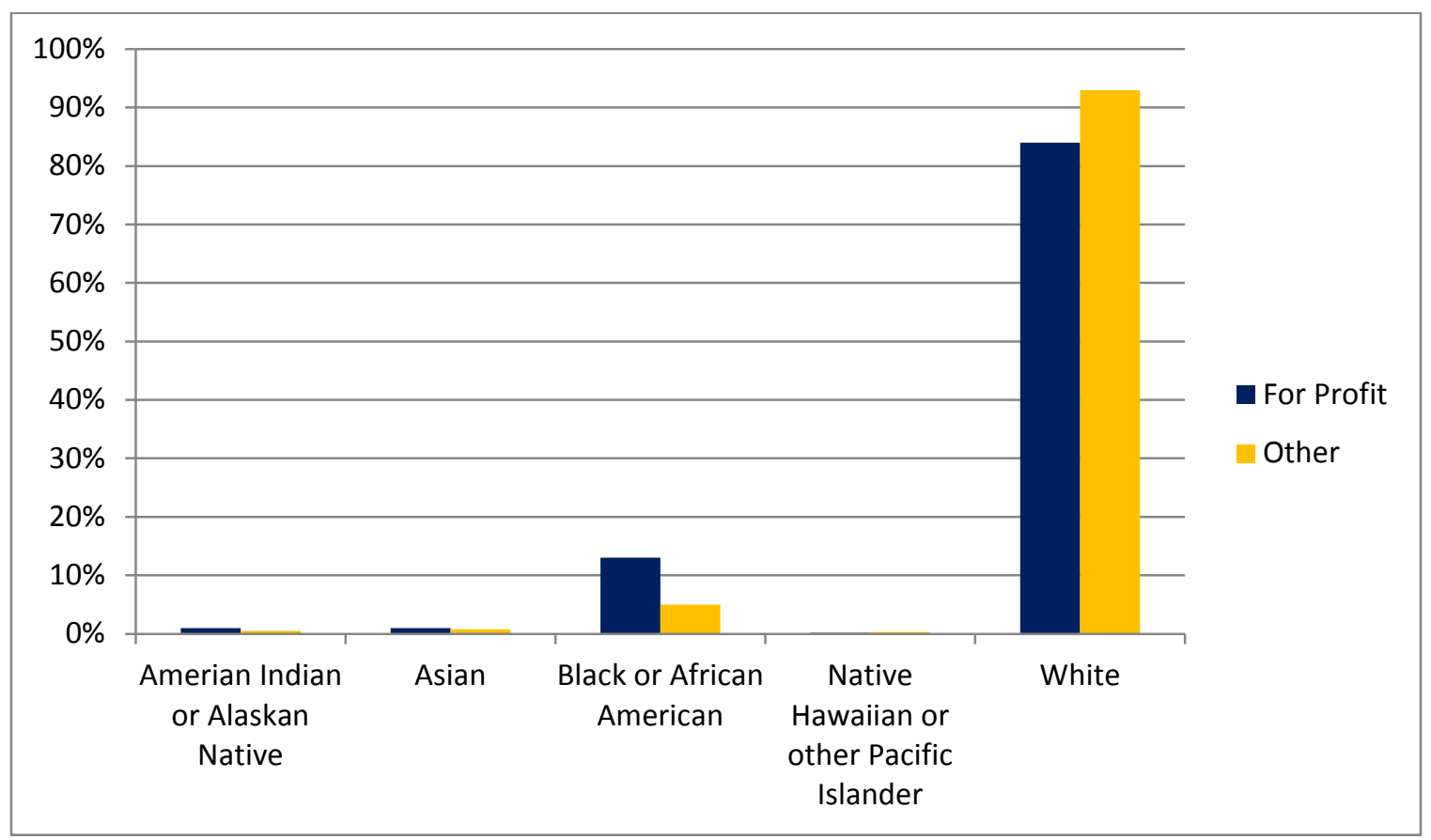


Figure 21. Ethnic Demographics of Hospice Patients

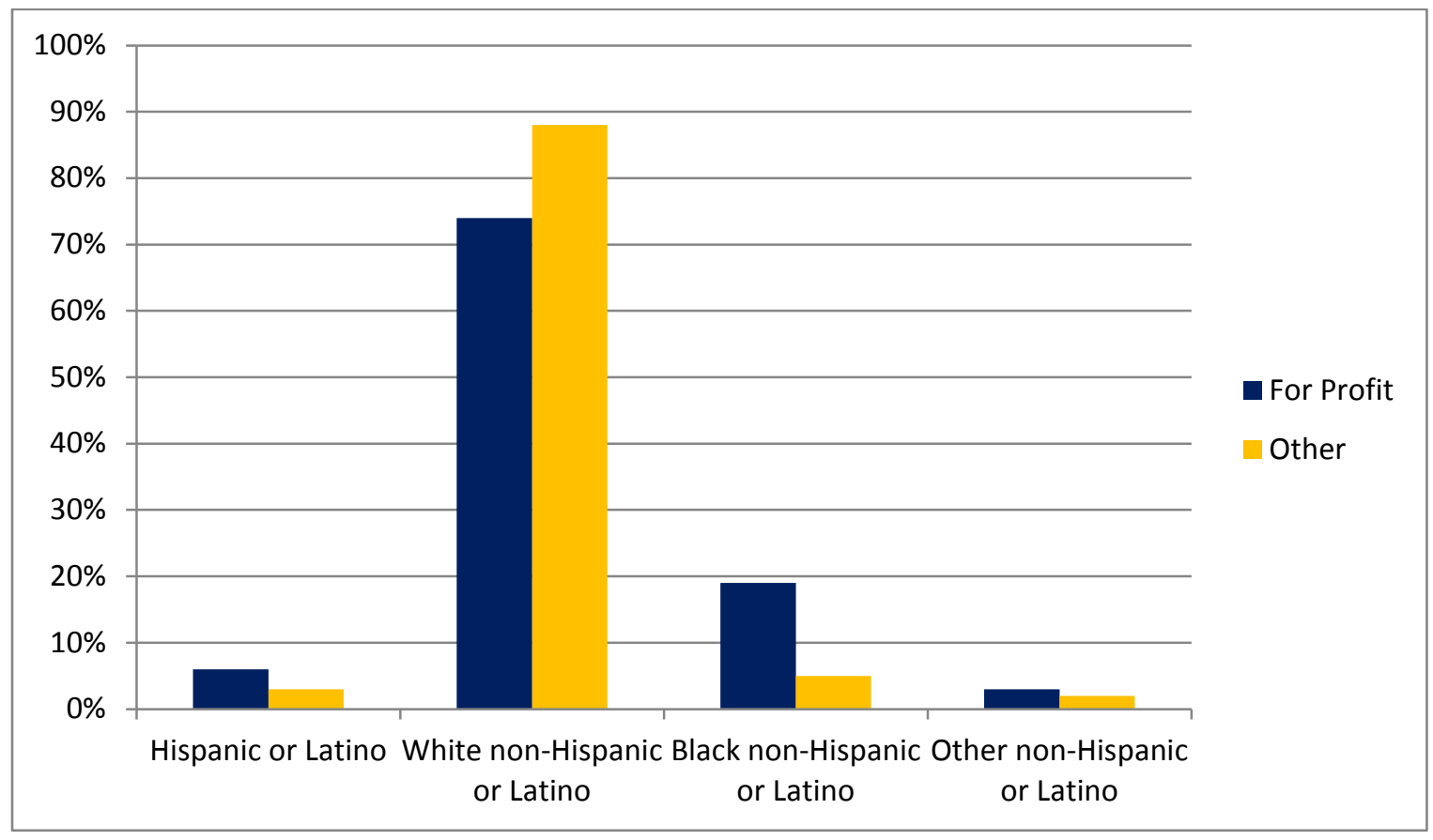

At all hospice agencies, most patients had Medicare as their payer source (65\% at for profit agencies and $72 \%$ at other hospice providers. Most of the patients in this study had a caregiver ( $85 \%$ at for profits and $88 \%$ at others). Specifically most had spousal or significant other caregivers (26\% at for profit and 33\% at other hospice providers. The majority of hospice patients lived with family members (61\% at for profits and 53\% at other hospice providers). More specifically, 28\% of for profit patients lived with their spouse or significant other and 32\% lived with their spouse or significant other at other hospices. Most patients lived in a private home or apartment at the beginning of care (29\% at for profits and 44\%). Similarly, most patients lived in a private home at the end of care (25\% at for profit agencies and 39\% at other hospices). (see Figures 22- 28) 
Figure 22. Primary Patient Payer Sources at For Profit Hospices

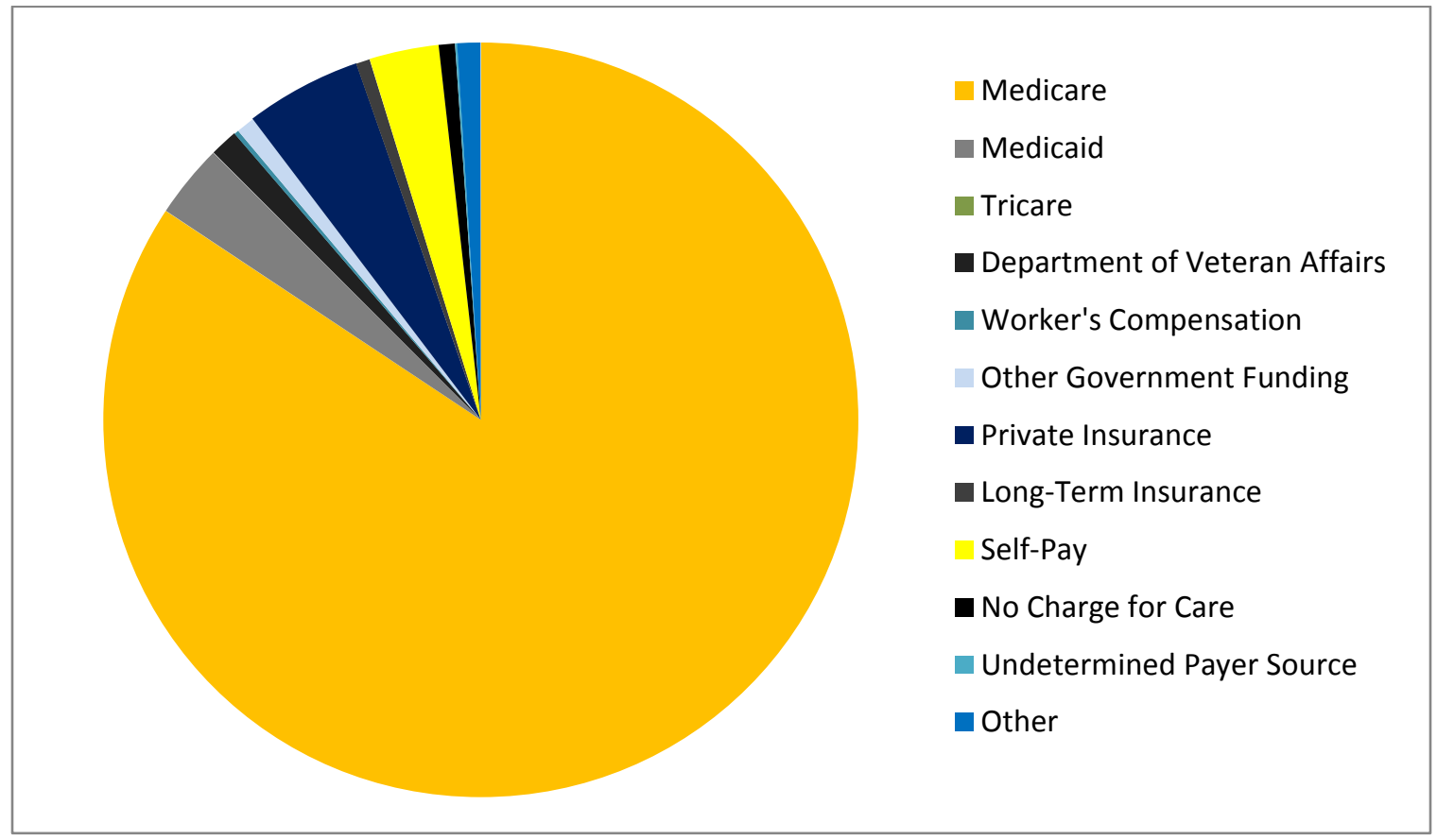

Figure 23. Primary Patient Payer Sources at Not-for-Profit and Government Owned Hospices

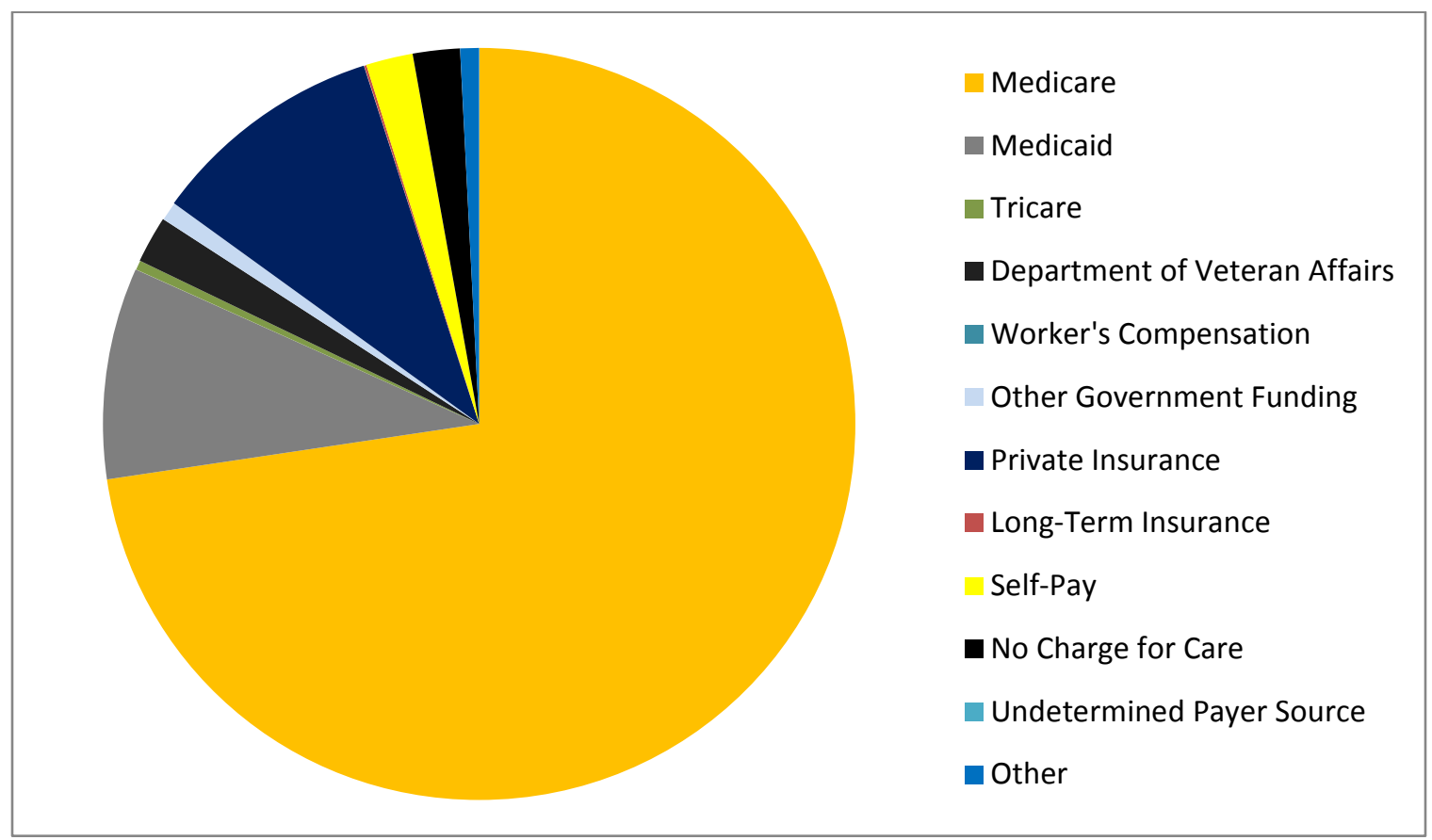


Figure 24. Hospice Patient Caregiver Status

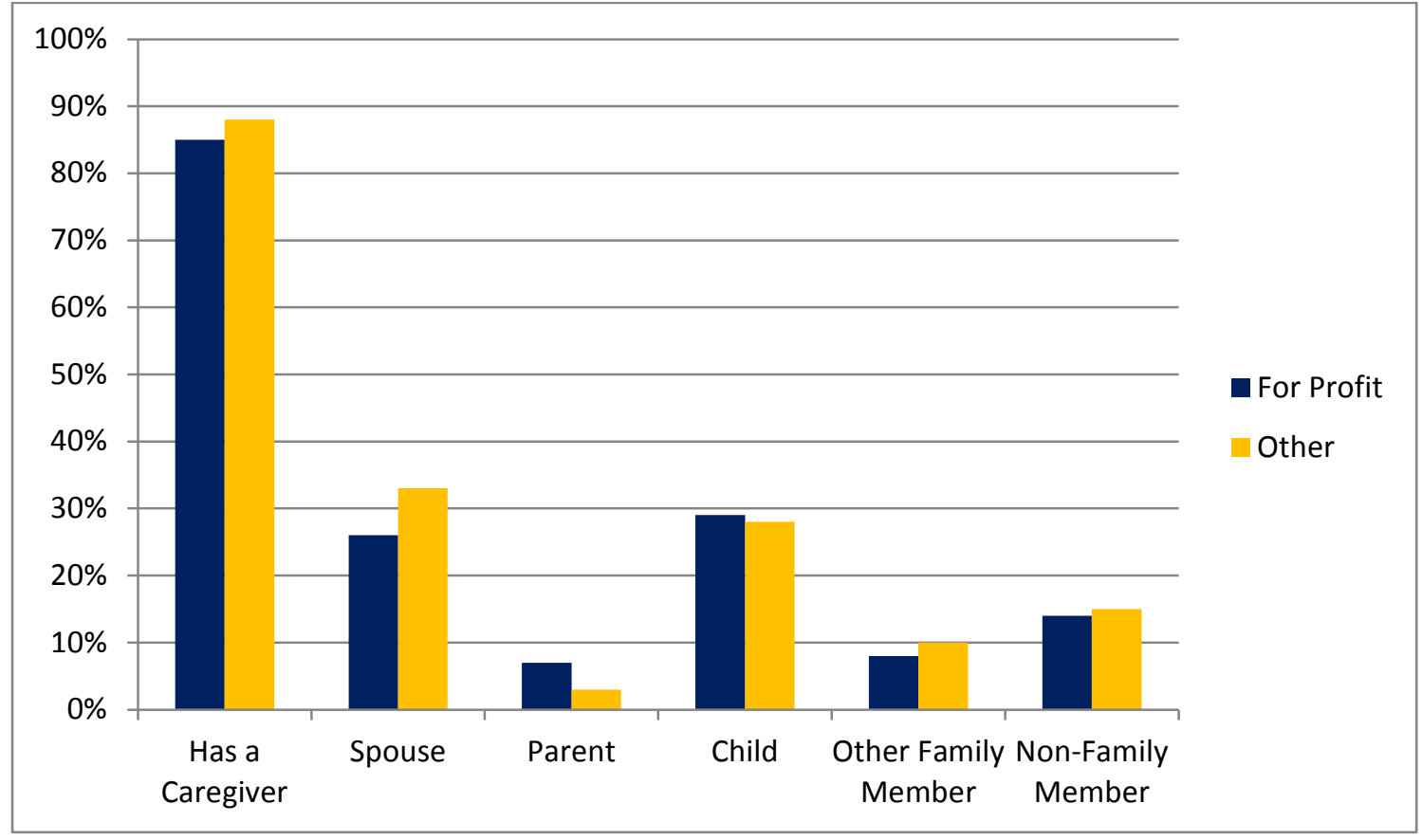

Figure 25. Hospice Patient Household Membership

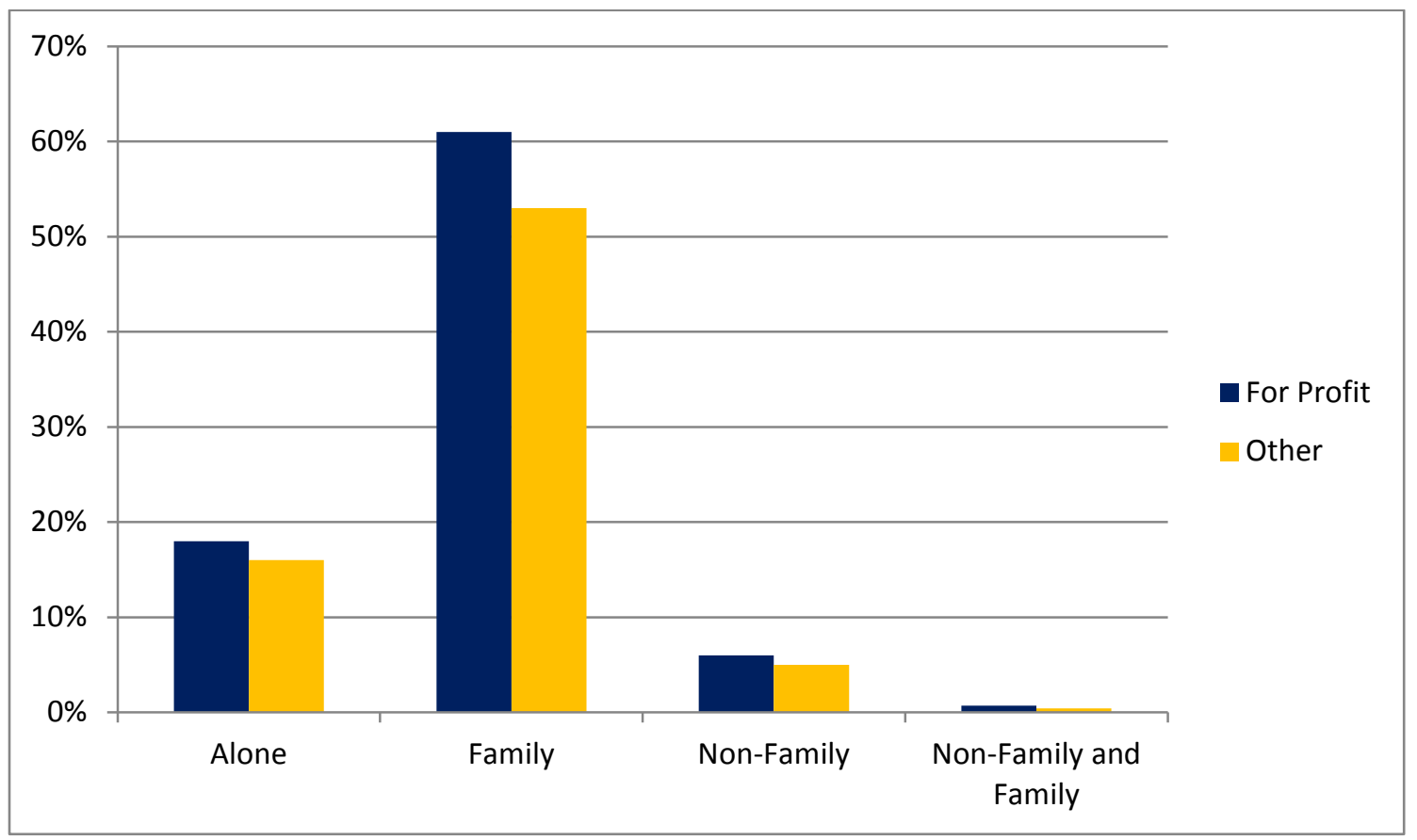


Figure 26. Hospice Patient Specific Household Membership with Family Members

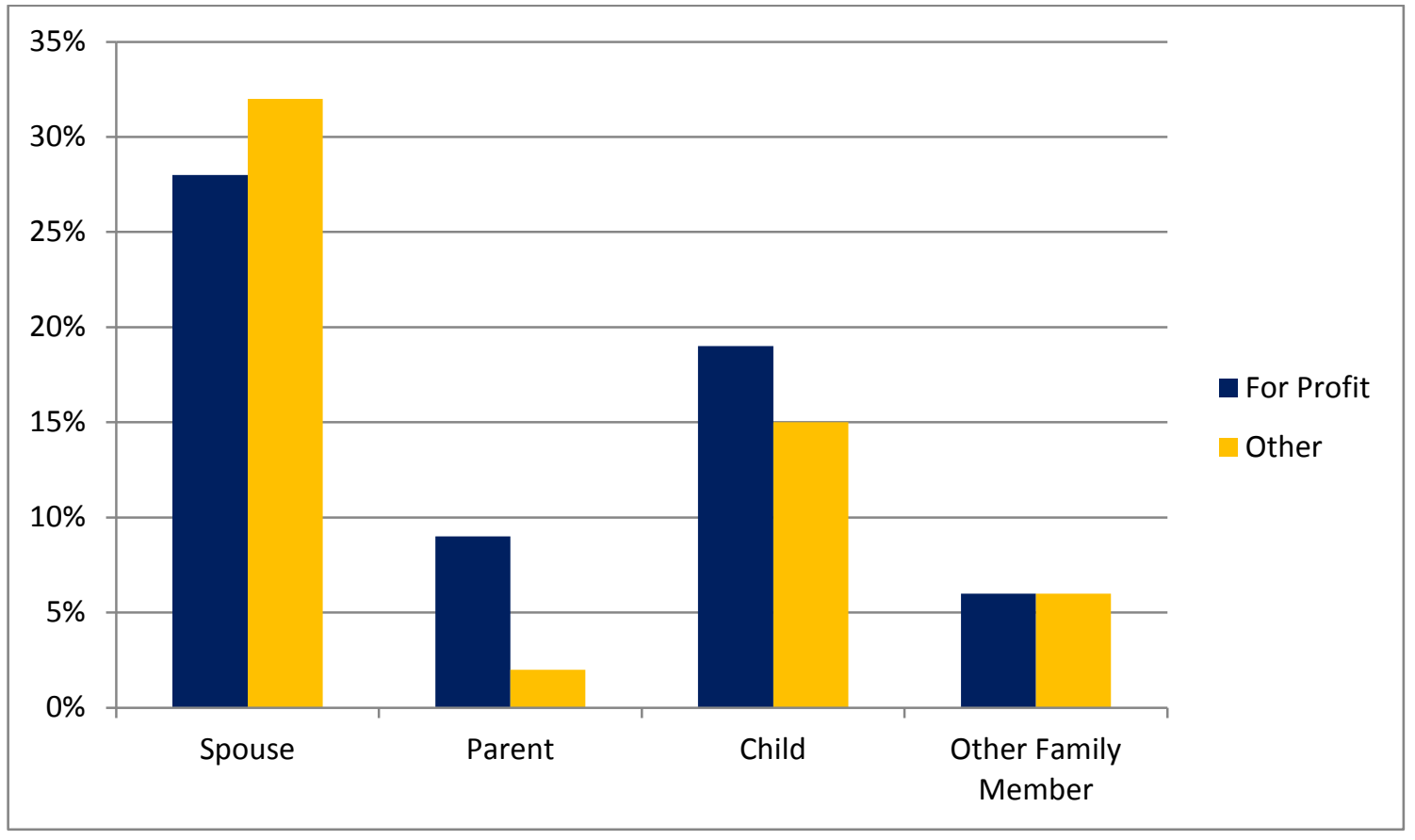

Figure 27. Patient Location of Residence at the Beginning of Hospice Care

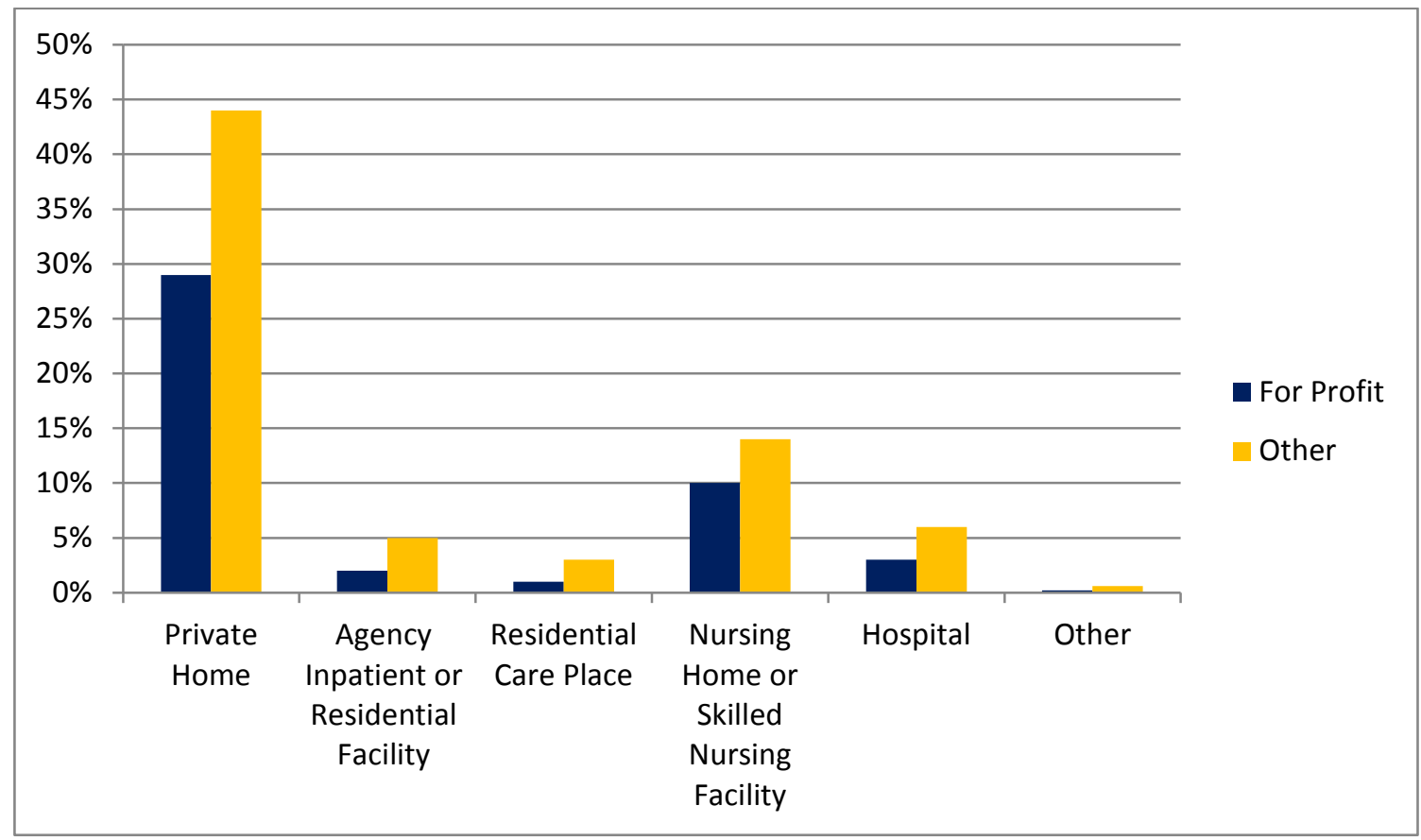


Figure 28. Patient Location of Residence at the End of Hospice Care

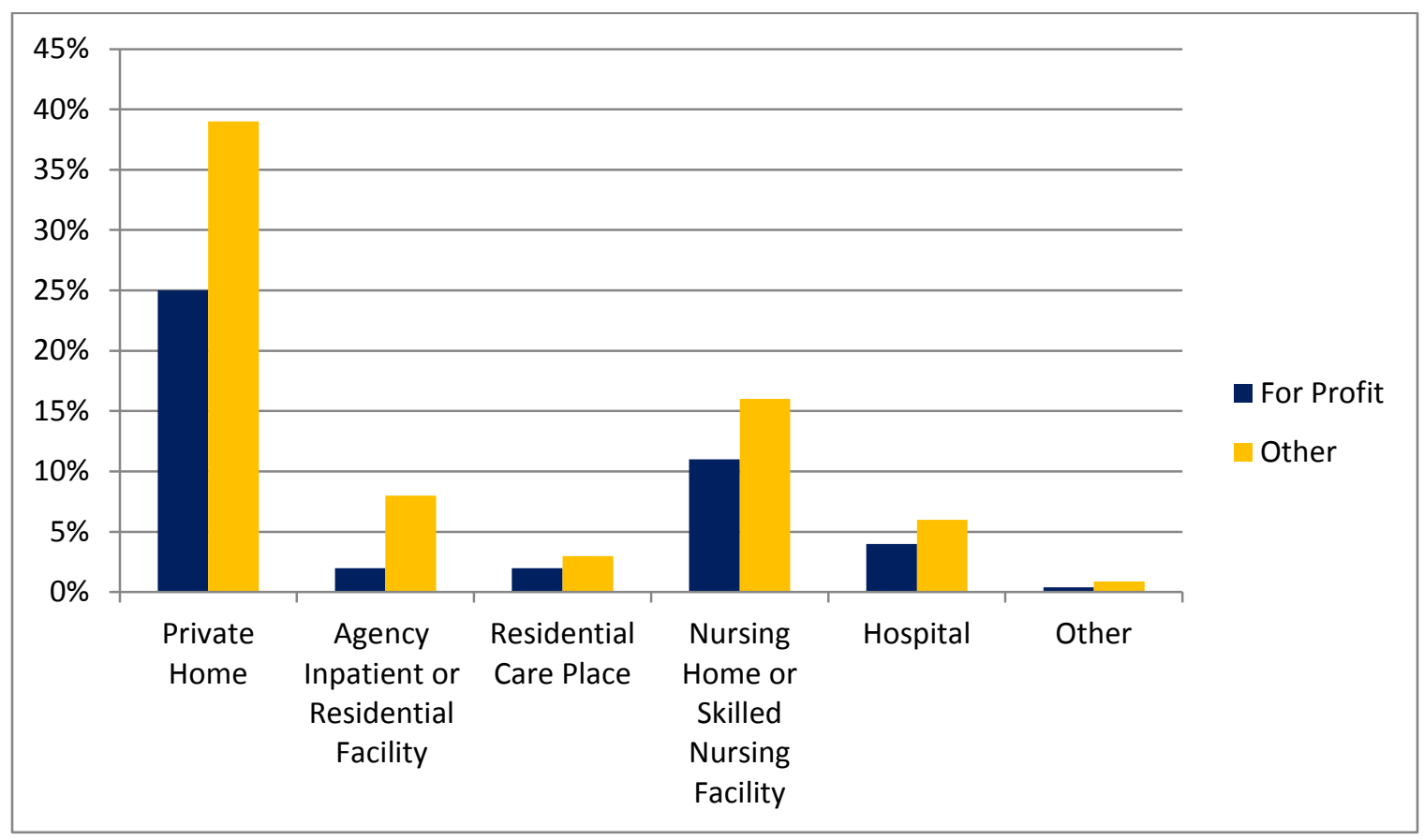

\section{Research Question \#1}

Multiple regressions were conducted to determine if hospice agency ownership status would predict psychosocial service availability. The first logistic regression that was conducted examined the probability of ownership status predicting medical social service availability while controlling for agency chain status and size. Overall, the model was significant, $\chi^{2}(1)=7.077, p=.008$, Nagelkerke $\mathrm{R}^{2}=.168$. This model correctly predicted 93.6\% of cases. Agency ownership status was a significant predictor, $p=.045$, and had an odds ratio of 8.309, indicating that for profit agencies are 8 times more likely to have medical social services available than hospice agencies with a different ownership status.

Secondly, the probability of ownership status predicting grief/bereavement support availability while controlling for agency chain status and size was analyzed by 
hierarchical logistic regression. The overall model was not significant, $\chi^{2}(1)=.265, p=$ .607 , Nagelkerke $\mathrm{R}^{2}=.023$. Agency ownership status was not a significant predictor, $p=$ .208 and had an odds ratio of 1.502 . This indicates that agency ownership status may not predict the likelihood of the availability of grief/bereavement services.

The next regression that was conducted examined the probability of ownership status predicting resource referral service availability while controlling for agency chain status and size. Overall, the model was not significant, $\chi^{2}(1)=.889, p=.346$, Nagelkerke $\mathrm{R}^{2}=.008$. Agency ownership status was not a significant predictor, $p=.341$, and had an odds ratio of .707, indicating that hospice agency ownership status may not predict resource referral service availability.

Next, the probability of ownership status predicting mental health service availability while controlling for agency chain status and size was analyzed. Overall, the model was not significant, $\chi^{2}(1)=.041, p=.839$, Nagelkerke $\mathrm{R}^{2}=.033$. Agency ownership status was not a significant predictor of mental health service availability, $p=$ .839 , and had an odds ratio of 1.061 . This could mean that hospice agency ownership status may not predict mental health service availability.

The next regression analyzed the probability of ownership status predicting respite service availability while controlling for agency chain status and size. Overall, the model was not significant, $\chi^{2}(1)=.009, p=.925$, Nagelkerke $\mathrm{R}^{2}=.022$. Agency ownership status was not a significant predictor, $p=.925$, and had an odds ratio of 1.059, meaning that hospice agency ownership status may not predict respite care service availability. 
The next regression that was conducted examined the probability of ownership status predicting advanced directive support availability by examining the following factors upon admitting the patient: 1) advanced directive status, 2) provision of advanced directive information, 3) provision of advanced directive forms, 4) educating the patient about advanced directives, 5) only providing advanced directive information when asked, and 6) having restrictions on implementing advanced directives. All of these variables were analyzed while controlling for agency chain status and size.

The model for the evaluation of patient advanced directives upon admission was not significant, $\chi^{2}(1)=.175, p=.676$, Nagelkerke $\mathrm{R}^{2}=.283$. Agency ownership status was not a significant predictor of advanced directive assessment, $p=.687$, and had an odds ratio of 1.639. The model for the provision of advanced directive information upon admission was not significant, $\chi^{2}(1)=.1 .414, p=.234$, Nagelkerke $\mathrm{R}^{2}=.094$. Provision of advanced directive information was not significantly predicted by agency ownership status, $p=.221$ with an odds ratio of .462 .

The model for the provision of patient advanced directive forms upon admission was also insignificant, $\chi^{2}(1)=.006, p=.939$, Nagelkerke $\mathrm{R}^{2}=.044$. Agency ownership status was not a significant predictor of advanced directive form provision, $p=.939$ with a .960 odds ratio. The model for education of patients of advanced directives upon admission was not significant, $\chi^{2}(1)=.873, p=.350$, Nagelkerke $\mathrm{R}^{2}=.101$. Agency ownership status was not a significant predictor of patient/family education about advanced directives, $p=.395$, and had an odds ratio of 2.619. The provision of advanced directive information only when asked produced a model that was not significant, $\chi^{2}(1)=$ 
1.116, $p=.291$, Nagelkerke $\mathrm{R}^{2}=.032$. Agency ownership status was not a significant predictor, $p=.284$, and had an odds ratio of 1.535 .

Finally, the model for the restriction of advanced directive implementation was also insignificant, $\chi^{2}(1)=.383, p=.536$, Nagelkerke $\mathrm{R}^{2}=.024$. Agency ownership status was not a significant predictor of advanced directive implementation restrictions, $p$ $=.541$, with an odds ratio of .763 . These results indicate that none of the aforementioned models explained any more than $28 \%$ of the variance in each dependent variable. In addition, it does not appear that advanced directive support service availability can be predicted by hospice agency ownership status when controlling for agency size and chain status.

The last hierarchal logistic regression that was conducted was to examine the probability of availability of ethical issues counseling services based on ownership status. Overall, the model was not significant, $\chi^{2}(1)=.556, p=.456$, Nagelkerke $\mathrm{R}^{2}=.026$. Agency ownership status was not a significant predictor of ethical issues counseling availability, $p=.454$, and had an odds ratio of 7.94. It is possible that hospice agency ownership status may not predict ethical issues counseling service availability when controlling for agency size and chain status. (see Table 1) 


\section{Table 1}

Hierarchal Logistic Regression Psychosocial Service Availability Based on Hospice Agency Ownership Status

\begin{tabular}{|c|c|c|c|c|c|}
\hline & & & \multicolumn{2}{|c|}{ 95\% CI } & \multirow[b]{2}{*}{$p$} \\
\hline & $\mathrm{B}$ & $\begin{array}{l}\text { Odds } \\
\text { Ratio } \\
\end{array}$ & Lower & Upper & \\
\hline Medical Social Services & 2.117 & 8.309 & 1.049 & 65.810 & $.045^{*}$ \\
\hline Grief/Bereavement Support & .407 & 1.502 & .309 & 7.229 & .614 \\
\hline Resource Referral & -.346 & .707 & .347 & 1.442 & .341 \\
\hline Mental Health Services & .059 & 1.061 & .601 & 1.870 & .839 \\
\hline Respite Services & .058 & 1.059 & .319 & 3.519 & .925 \\
\hline \multicolumn{6}{|l|}{ Advanced Directive (AD) Support } \\
\hline AD Assessment & .494 & 7.582 & .148 & 18.168 & .687 \\
\hline AD Information & -.771 & .462 & .135 & 1.588 & .221 \\
\hline AD Forms & -.041 & .960 & .333 & 2.765 & .939 \\
\hline AD Education & .963 & 2.619 & .285 & 24.065 & .395 \\
\hline AD Information Only If Asked & .429 & 1.535 & .700 & 3.366 & .284 \\
\hline Restriction on AD Implementation & -.270 & .763 & .321 & 1.815 & .541 \\
\hline Ethical Counseling & -.230 & .794 & .435 & 1.451 & .454 \\
\hline
\end{tabular}

$* p$ values $\leq .05$ 


\section{Research Question \#2}

Hierarchal linear regression and hierarchical logistic regressions were conducted to determine if hospice agency ownership status would predict psychosocial service utilization. The first logistic regression examined the probability of ownership status predicting medical social service utilization while controlling for agency chain status and patient total ADLs. The overall model was significant, $\chi^{2}(1)=62.593, p=.000$, Nagelkerke $\mathrm{R}^{2}=.131$. This model correctly classified 63.8\% of cases. Agency ownership status was a significant predictor, $p=.000$, and with an odds ratio of .426 , indicating that patients at for profit hospice agencies are 4 times less likely to utilize medical social services than agencies with different a ownership status.

Next, hierarchal linear regression was used examined the probability of ownership status predicting medical social service visit frequency while controlling for agency chain status and patient total ADLs. The model explained 22\% of variance in medical social service frequency $(\mathrm{F}(3,2411)=17.668, p<.05$. There was no significant difference between for profit medical social service visits and hospice agencies with a different ownership status. Agency ownership status was not a significant predictor of medical social service visit frequency when taking into account agency chain status and patient total ADLs.

The next logistic regression examined the probability of ownership status predicting patient family/friend utilization of bereavement services while controlling for agency chain status and patient total ADLs. The overall model was significant, $\chi^{2}(1)=$ 101.061, $\mathrm{p}=.000$, Nagelkerke $\mathrm{R}^{2}=.203$. This model correctly classified $67.3 \%$ of cases. Agency ownership status was a significant predictor of patient/family utilization of 
bereavement services, $p=.000$ with an odds ratio of .331 . This indicates that families/friends at hospices that are for profit are 3 times less likely to utilize bereavement services than those at not-for-profit or government owned hospices.

Next, a logistic regression was conducted to examine the probability of ownership status predicting referral service utilization while controlling for agency chain status and patient total ADLs. The overall model was not significant, $\chi^{2}(1)=2.373, \mathrm{p}=.123$, Nagelkerke $\mathrm{R}^{2}=.021$. Agency ownership status was not a significant predictor of resource referral usage, $p=.119$ and had an odds ratio of 1.309 .

The next logistic regression examined the probability of ownership status predicting mental health service utilization while controlling for agency chain status and patient total ADLs. The overall model was not significant, $\chi^{2}(1)=.675, \mathrm{p}=.411$, Nagelkerke $\mathrm{R}^{2}=.056$. Agency ownership status was not a significant predictor, $p=.418$, and with an odds ratio of .712.

Next, the probability of ownership status predicting respite service utilization was examined while controlling for agency chain status and patient total ADLs. The overall model was not significant, $\chi^{2}(1)=.000, \mathrm{p}=.986$, Nagelkerke $\mathrm{R}^{2}=.016$. Agency ownership status was not a significant predictor, $p=.986$, and with an odds ratio of 1.004.

The final logistic regression examined the probability of ownership status predicting ethical issues counseling utilization while controlling for agency chain status and patient total ADLs. The overall model was not significant, $\chi^{2}(1)=.004, \mathrm{p}=.950$, Nagelkerke $\mathrm{R}^{2}=.019$. Agency ownership status was not a significant predictor, $p=.950$, and with an odds ratio of 1.015. (see Tables 2 and 3) 


\section{Table 2}

Hierarchal Logistic Regression Psychosocial Service Utilization Based on Hospice Agency Ownership

\begin{tabular}{|c|c|c|c|c|c|c|}
\hline & & & & & & \\
\hline & $\mathrm{B}$ & S.E. & Odds Ratio & Lower & Upper & $p$ \\
\hline Medical Social Services & -.821 & .109 & .426 & .345 & .528 & $.000 *$ \\
\hline Bereavement Services & -1.105 & .112 & .331 & .266 & .412 & $.000^{*}$ \\
\hline Resource Referral Services & .269 & .173 & 1.309 & .993 & 1.836 & .119 \\
\hline Mental Health Services & -.339 & .419 & .712 & .313 & 1.620 & .418 \\
\hline Respite Care Services & .004 & .215 & 1.004 & .659 & 1.529 & .986 \\
\hline Ethical Counselling Services & .014 & .232 & 1.015 & .643 & 1.600 & .950 \\
\hline
\end{tabular}

$* p$ values $\leq .05$

Table 3

Hierarchal Linear Regression Medical Social Service Visit Frequency Based on Hospice Agency Ownership Status

\begin{tabular}{|l|c|c|c|}
\hline & B. & S.E. & $p$ \\
\hline Medical Social Service Visit Frequency & .463 & .360 & .198 \\
\hline
\end{tabular}

$* p$ values $\leq .05$ 


\section{Research Question \#3}

To examine the overall utilization of psychosocial services in addition to the characteristics of patients and caregivers that used these services, cross tabulations were conducted. The independent variables for research question number three were 1) primary diagnosis, 2) cognitive status, 3) patient total ADL needs, 4) level of care, 5) length of service (days on hospice), 6) payer source, 7) age at discharge, 8) race (including American Indian, Asian, Black/African-American, Pacific Islander, or White), 9) ethnicity (Hispanic or non-Hispanic), 10) gender, 11) marital status, 12) veteran status, 13) location of service at the beginning of hospice, 14) location of service at the end of hospice, 15) caregiver status, 16) identification of the patient caregiver, and 17) household membership.

The dependent variables were the following: 1) used medical social services. 2) medical social service visit frequency, 3) used resource referral services, 4) used mental health services, 5) used respite care services, 6) used ethical issues counseling services, 7) advanced directive status and psychosocial service utilization , 8) used interpreter services, 9) used homemaker services, 10) used transportation services, 11) used Meals on Wheels services , 12) used complementary and alternative medicine services, 13) used pastoral care services, and 14) used volunteer services.

For variables specific to caregiver services, the dependent variables will be 1) used bereavement services, 2) used caregiver health and wellness services, 3) used spiritual care services, 4) used dealing with difficult behavior services, 5) used safety training services, 6) used suspected abuse or neglect services, and 6) used resource referral information services. 


\section{Characteristics of Patients Who Use Psychosocial Services}

Medical social service use and frequency. Overall, 40\% of patients utilized medical social service and had an average of 2.15 visits while under hospice care. The majority of the patients who used this service had cancer, specifically either the lung, bronchial, or tracheal form of the disease (13.9\%). Visit frequency was not significant. Those with no cognitive impairment utilized medical social services the most (35.8\%) with an average visit frequency of 1.75 while under hospice care. Patients with four total ADL needs represented the most patients that used this service (26.3\%) with 2.75 visits on average.

Hospice patients under routine home care represented $75.9 \%$ of patients that used medical social services with the highest average visit frequency of 4 visits while being a hospice patient. Patients who used medical social services had an average length of 75.5 service days with the average of 2.15 visits. Medicare patients represented $82 \%$ of those who used this service and visit frequency was not significant. Patient age and gender were not significantly related to medical social service use or visit frequency. White and Black or African American racial identities were the only significant races that related to use of medical social services. White patients used this service the most (91\%) with a visit frequency of 2.75 visits. Furthermore, White non-Hispanics represented the highest amount of patients that used medical social services (86.2\%). Visit frequency was not significant. Married patients accounted for $42.4 \%$ of patients who used this service with an average of 2 visits while under hospice care. Veterans represented $11.7 \%$ of patients who used this service. Visit frequency was not significant. 
Results indicated that $92.1 \%$ of patients who used medical social services had a caregiver and had an average of 2.25 visits. Those with their child as the caregiver represented $30.9 \%$ of patients who used this service with a visit frequency of 2.5 visits. Patients who lived with a family member accounted for most of the patients who used this service (53.3\%) with an average of 2 visits. More specifically, those who had household membership with their spouse represented 31\% of those who lived with a family member and used medical social services with a visit frequency of 1.75. Patients that lived in a private home at the beginning of care accounted for $58 \%$ and had an average of 4 visits while under hospice care. At the end of care, patients that lived in a private home also represented the most of the patients that used medical social services (51.6\%) and similarly had a visit frequency of 3.5 visits. (see Tables 4-8) 
Table 4

Patient Medical Social Service Utilization \&Visit Frequency Based on Primary Diagnosis, Cognitive Status, \& Total ADL Needs

\begin{tabular}{|c|c|c|c|c|c|c|c|c|}
\hline & $\begin{array}{c}\text { \% of } \\
\text { Those } \\
\text { Who } \\
\text { Used the } \\
\text { Service }\end{array}$ & $\chi^{2}$ & df & $p$ & $\begin{array}{c}\text { Average Visit } \\
\text { Frequency }\end{array}$ & $\chi^{2}$ & df & $p$ \\
\hline $\begin{array}{l}\text { Diagnosis } \\
\text { Lung, Bronchial, or Tracheal Cancer } \\
\text { Heart Failure } \\
\text { Organic Psychotic Conditions } \\
\text { Non-Specified Chronic Airway Obstruction } \\
\text { Unknown Cause of Morbidity } \\
\text { Nutrition or Metabolism Developmental } \\
\text { Disorders }\end{array}$ & $\begin{array}{c}13.9 \% \\
7.6 \% \\
6.1 \% \\
6 \% \\
\\
5.5 \% \\
5.4 \%\end{array}$ & 967.912 & 229 & $.000 *$ & N.S. & 7453.241 & 11679 & 1.000 \\
\hline $\begin{array}{l}\text { Cognitive Status } \\
\text { No Cognitive Impairment } \\
\text { Occasional Reminders } \\
\text { Some Assistance } \\
\text { Great Deal of Assistance } \\
\text { Severe Cognitive Impairment }\end{array}$ & $\begin{array}{c}35.8 \% \\
16.1 \% \\
14.9 \% \\
16.3 \% \\
8.9 \% \\
\end{array}$ & 121.325 & 6 & $.000 *$ & $\begin{array}{c}1.75 \\
2 \\
2.5 \\
3 \\
3.5 \\
\end{array}$ & 470.806 & 306 & $.000 *$ \\
\hline $\begin{array}{l}\text { Patient Total ADL Needs } \\
\text { None } \\
\text { One } \\
\text { Two } \\
\text { Three } \\
\text { Four } \\
\text { Five }\end{array}$ & $\begin{array}{c}8.9 \% \\
8.4 \% \\
8.3 \% \\
19.4 \% \\
26.3 \% \\
23.4 \%\end{array}$ & 129.382 & 7 & $.000 *$ & $\begin{array}{c}2.25 \\
1 \\
1.5 \\
1.75 \\
2.75 \\
2.75\end{array}$ & 503.359 & 357 & $.000 *$ \\
\hline
\end{tabular}

$* p$ values $\leq .05$ 
Table 5

Patient Medical Social Service Utilization \& Visit Frequency Based on Level of Care, Length of Service, \& Payer

\begin{tabular}{|c|c|c|c|c|c|c|c|c|}
\hline & $\begin{array}{l}\% \text { of Those } \\
\text { Who Used } \\
\text { the Service }\end{array}$ & $\chi^{2}$ & df & $p$ & $\begin{array}{c}\text { Average Visit } \\
\text { Frequency }\end{array}$ & $\chi^{2}$ & df & $p$ \\
\hline $\begin{array}{l}\text { Level of Care } \\
\text { Routine Homecare } \\
\text { Continuous Home Care } \\
\text { General Inpatient } \\
\text { Inpatient Respite } \\
\end{array}$ & $\begin{array}{c}75.9 \% \\
3.9 \% \\
14.9 \% \\
.7 \% \\
\end{array}$ & 1240.573 & 6 & $.000 *$ & $\begin{array}{c}4 \\
3.5 \\
3.5 \\
3 \\
\end{array}$ & 1594.859 & 306 & $.000 *$ \\
\hline Length of Service & $\begin{array}{l}\text { Avg. } \\
75.5 \text { days }\end{array}$ & 1429.953 & 293 & $.000 *$ & 2.15 & $\begin{array}{c}75869.69 \\
7\end{array}$ & 14843 & $.000 *$ \\
\hline $\begin{array}{l}\text { Payer Source } \\
\text { Medicare } \\
\text { Medicaid } \\
\text { Tricare } \\
\text { Department of Veteran Affairs } \\
\text { Worker's Compensation } \\
\text { Other Government Funding } \\
\text { Private Insurance } \\
\text { Long-Term Care Insurance } \\
\text { Self-Pay } \\
\text { No Charge for Care } \\
\text { Undetermined Payer Source } \\
\text { Other }\end{array}$ & $\begin{array}{c}82 \% \\
3.7 \% \\
.3 \% \\
1.3 \% \\
0 \% \\
.3 \% \\
7.6 \% \\
.3 \% \\
1 \% \\
.8 \% \\
.2 \% \\
.6 \%\end{array}$ & 278.418 & 14 & $.000 *$ & N.S. & 671.196 & 714 & .873 \\
\hline
\end{tabular}

$* p$ values $\leq .05$ 
Table 6

Patient Medical Social Service Utilization \&Visit Frequency Based on Age at Discharge, Gender, Race, Ethnicity, Marital Status, \& Veteran Status

\begin{tabular}{|c|c|c|c|c|c|c|c|c|}
\hline & $\begin{array}{l}\% \text { of Those Who } \\
\text { Used the Service }\end{array}$ & $\chi^{2}$ & df & $p$ & $\begin{array}{c}\text { Average Visit } \\
\text { Frequency }\end{array}$ & $\chi^{2}$ & $\mathrm{df}$ & $p$ \\
\hline Patient Age at Discharge & N.S. & 82.246 & 75 & .265 & N.S. & 3507.250 & 3825 & 1.000 \\
\hline $\begin{array}{l}\text { Gender } \\
\text { Male } \\
\text { Female } \\
\end{array}$ & N.S. & 2.356 & 1 & .125 & N.S. & 63.677 & 51 & .110 \\
\hline $\begin{array}{l}\text { Race } \\
\text { American Indian or } \\
\text { Alaskan Native } \\
\text { Asian } \\
\text { Native Hawaiian or other } \\
\text { Pacific Islander } \\
\text { Black or African } \\
\text { American } \\
\text { White } \\
\end{array}$ & $\begin{array}{l}\text { N.S. } \\
\text { N.S. } \\
\text { N.S. } \\
7.1 \% \\
91 \%\end{array}$ & $\begin{array}{c}.649 \\
711 \\
.684 \\
9.923 \\
8.045\end{array}$ & $\begin{array}{l}1 \\
1 \\
1 \\
1 \\
1\end{array}$ & $\begin{array}{l}.421 \\
.191 \\
.408 \\
.002^{*} \\
.005^{*}\end{array}$ & $\begin{array}{c}4.25 \\
\text { N.S. } \\
\text { N.S. } \\
2.5 \\
2.75\end{array}$ & $\begin{array}{c}172.289 \\
34.545 \\
13.210 \\
102.498 \\
101.776\end{array}$ & $\begin{array}{l}67 \\
67 \\
67 \\
67 \\
67\end{array}$ & $\begin{array}{l}.000^{*} \\
1.00 \\
1.00 \\
.003^{*} \\
.004^{*}\end{array}$ \\
\hline $\begin{array}{l}\text { Ethnicity } \\
\text { Hispanic or Latino } \\
\text { White Non-Hispanic or } \\
\text { Latino } \\
\text { Black Non-Hispanic or } \\
\text { Latino } \\
\text { Other Non-Hispanic or } \\
\text { Latino }\end{array}$ & $\begin{array}{c}3.1 \% \\
86.2 \% \\
7 \% \\
1.9 \%\end{array}$ & 38.089 & 4 & $.000^{*}$ & N.S. & 285.310 & 268 & .223 \\
\hline $\begin{array}{l}\text { Marital Status } \\
\text { Married } \\
\text { Widowed } \\
\text { Divorced } \\
\text { Separated } \\
\text { Never Married } \\
\text { Living with a Partner }\end{array}$ & $\begin{array}{c}42.4 \% \\
39.6 \% \\
6.8 \% \\
.8 \% \\
5.9 \% \\
.7 \% \\
\end{array}$ & 79.344 & 6 & $.000 *$ & $\begin{array}{c}2 \\
2.75 \\
2.25 \\
1.5 \\
1.25 \\
1\end{array}$ & 353.673 & 306 & $.031^{*}$ \\
\hline Veteran & $11.7 \%$ & 24.931 & 3 & $.000 *$ & N.S. & 151.885 & 153 & .510 \\
\hline
\end{tabular}

$* p$ values $\leq .05$ 
Table 7

Patient Medical Social Service Utilization \& Visit Frequency Based on Caregiver Status \& Household Membership

\begin{tabular}{|c|c|c|c|c|c|c|c|c|}
\hline & $\begin{array}{c}\% \text { of Those } \\
\text { Who Used the } \\
\text { Service }\end{array}$ & $\chi^{2}$ & $d f$ & $p$ & $\begin{array}{c}\text { Average } \\
\text { Visit } \\
\text { Frequency } \\
\end{array}$ & $\chi^{2}$ & $d f$ & $p$ \\
\hline Caregiver & $92.1 \%$ & 69.833 & 2 & $.000^{*}$ & 2.25 & 130.315 & 102 & $\begin{array}{c}.031 \\
*\end{array}$ \\
\hline $\begin{array}{l}\text { Identification of the Caregiver } \\
\text { Spouse } \\
\text { Child } \\
\text { Parent } \\
\text { Other family Member } \\
\text { Non-Family Member }\end{array}$ & $\begin{array}{c}32.6 \% \\
30.9 \% \\
2 \% \\
9.3 \% \\
17.3 \%\end{array}$ & 113.843 & 6 & $.000 *$ & $\begin{array}{c}2 \\
2.5 \\
.5 \\
2.25 \\
3\end{array}$ & 396.305 & 306 & $\begin{array}{c}.000 \\
*\end{array}$ \\
\hline $\begin{array}{l}\text { Household Membership } \\
\text { Alone } \\
\text { Family }\end{array}$ & $\begin{array}{l}10.5 \% \\
53.3 \%\end{array}$ & 181.683 & 5 & $.000 *$ & $\begin{array}{c}1.25 \\
2\end{array}$ & 434.763 & 225 & $\begin{array}{c}.000 \\
*\end{array}$ \\
\hline $\begin{array}{l}\text { Spouse or Significant Other } \\
\text { Parent } \\
\text { Child } \\
\text { Other Family Members } \\
\text { Non-Family Members } \\
\text { Family and Non-Family }\end{array}$ & $\begin{array}{c}31 \% \\
1 \% \\
17 \% \\
5 \% \\
\\
4.3 \% \\
.5 \%\end{array}$ & $\begin{array}{l}168.095 \\
182.963 \\
171.076 \\
143.255\end{array}$ & $\begin{array}{l}3 \\
3 \\
3 \\
3\end{array}$ & $\begin{array}{l}.000^{*} \\
.000^{*} \\
.000^{*} \\
.000^{*}\end{array}$ & $\begin{array}{c}1.75 \\
.25 \\
2.5 \\
1 \\
\\
2.5 \\
4.75\end{array}$ & $\begin{array}{l}352.087 \\
327.705 \\
360.340 \\
306.076\end{array}$ & $\begin{array}{l}153 \\
153 \\
153 \\
153\end{array}$ & $\begin{array}{l}.000 \\
* \\
.000 \\
* \\
.000 \\
* \\
.000 \\
*\end{array}$ \\
\hline
\end{tabular}

$* p$ values $\leq .05$ 
Table 8

Patient Medical Social Service Utilization \& Visit Frequency Based on Patient Location at the Beginning \& End of Care

\begin{tabular}{|c|c|c|c|c|c|c|c|c|}
\hline & $\begin{array}{l}\% \text { of Those } \\
\text { Who Used } \\
\text { the Service }\end{array}$ & $\chi^{2}$ & $d f$ & $p$ & $\begin{array}{l}\text { Average } \\
\text { Visit } \\
\text { Frequency }\end{array}$ & $\chi^{2}$ & $d f$ & $p$ \\
\hline $\begin{array}{l}\text { Location at the Beginning of Care } \\
\text { Private Home } \\
\text { Nursing Home/Skilled Nursing Facility } \\
\text { Hospital } \\
\text { Residential Care Place } \\
\text { Agency Inpatient/Residential Facility } \\
\text { Other }\end{array}$ & $\begin{array}{c}58 \% \\
19.6 \% \\
6.7 \% \\
5 \% \\
4.7 \% \\
.8 \%\end{array}$ & 3586.070 & 7 & $.000 *$ & $\begin{array}{c}4 \\
4.25 \\
1.75 \\
4.25 \\
2.5 \\
2.25\end{array}$ & 4788.416 & 469 & $.000 *$ \\
\hline $\begin{array}{l}\text { Location at the End of Care } \\
\text { Private Home } \\
\text { Nursing Home/Skilled Nursing Facility } \\
\text { Hospital } \\
\text { Residential Care Place } \\
\text { Agency Inpatient/Residential Facility } \\
\text { Other }\end{array}$ & $\begin{array}{c}51.6 \% \\
22.3 \% \\
7.4 \% \\
5.2 \% \\
7.7 \% \\
1.1 \%\end{array}$ & 3568.037 & 7 & $.000 *$ & $\begin{array}{c}3.5 \\
4.75 \\
2.5 \\
4.5 \\
3.5 \\
3\end{array}$ & 4829.430 & 469 & $.000 *$ \\
\hline
\end{tabular}

$* p$ values $\leq .05$ 
Resource referral services. The majority of the patients who used this service had either the lung, bronchial, or tracheal cancer (8\%). Those with no cognitive impairment utilized resource referral services the most (31.3\%). Patients with four total ADL needs represented the most patients that used this service (30\%). Hospice patients under routine home care represented $65.4 \%$ of patients that used resource referral services. Patient length of service was not significant. Medicare patients represented $76 \%$ of those who used this service. The average age of patients who used this service was 74. Patient gender was not significantly related to resource referral service use. Asian racial identity was the only significant racial identity representing $1.1 \%$ of patients who used this service. White non-Hispanics represented the highest amount of patients that used resource referral services (85.2\%). Married patients accounted for $42.2 \%$ of patients who used this service. Veterans represented $11.9 \%$ of patients who used resource referral services.

Of patients who used resource referral services, $86.1 \%$ had a caregiver. Those with a spousal caregiver represented $32.1 \%$ of patients who used this service. Patients who lived with a family member accounted for most of the patients who used this service (59.9\%). The only significant relationship between the specific family household member was if the patient lived with other family members. Patients that lived with other family members represented $10 \%$ of those who used resource referral services. Patients that lived in a private home at the beginning of care accounted for 53.3\%. At the end of care, patients that lived in a private home also represented the most of the patients that used resource referral services (45.3\%). (see Tables 9-13) 
Table 9

Patient Utilization of Resource Referral Services Based on Primary Diagnosis, Cognitive Status, \& Total ADL Needs

\begin{tabular}{|c|c|c|c|c|}
\hline & $\%$ of Those Who Used the Service & $\chi^{2}$ & df & $p$ \\
\hline $\begin{array}{l}\text { Diagnosis } \\
\text { Lung, Bronchial, or Tracheal Cancer } \\
\text { Heart Failure } \\
\text { Unspecified Chronic Airway Obstruction } \\
\text { Unknown Cause of Morbidity } \\
\end{array}$ & $\begin{array}{c}8 \% \\
5.1 \% \\
5.3 \% \\
5.6 \% \\
\end{array}$ & 1221.343 & 687 & $.000^{*}$ \\
\hline $\begin{array}{l}\text { Cognitive Status } \\
\text { No Cognitive Impairment } \\
\text { Occasional Reminders } \\
\text { Some Assistance } \\
\text { Great Deal of Assistance } \\
\text { Severe Cognitive Impairment }\end{array}$ & $\begin{array}{l}31.3 \% \\
15.6 \% \\
17.1 \% \\
20.6 \% \\
8.4 \% \\
\end{array}$ & 409.828 & 18 & $.000^{*}$ \\
\hline $\begin{array}{l}\text { Patient Total ADL Needs } \\
\text { None } \\
\text { One } \\
\text { Two } \\
\text { Three } \\
\text { Four } \\
\text { Five }\end{array}$ & $\begin{array}{c}12.1 \% \\
6.6 \% \\
9.1 \% \\
15.8 \% \\
30 \% \\
17.9 \%\end{array}$ & 514.577 & 21 & $.000 *$ \\
\hline
\end{tabular}

$* p$ values $\leq .05$ 
Table 10

Patient Utilization of Resource Referral Services Based on Level of Care, Length of Service, \& Payer Source

\begin{tabular}{|c|c|c|c|c|}
\hline & $\%$ of Those Who Used the Service & $\chi^{2}$ & df & $p$ \\
\hline $\begin{array}{l}\text { Level of Care } \\
\text { Routine Homecare } \\
\text { Continuous Home Care } \\
\text { General Inpatient } \\
\text { Inpatient Respite } \\
\end{array}$ & $\begin{array}{c}65.4 \% \\
2.7 \% \\
9.1 \% \\
.6 \% \\
\end{array}$ & 701.333 & 18 & $.000 *$ \\
\hline Length of Service & N.S. & 704.437 & 879 & 1.000 \\
\hline $\begin{array}{l}\text { Payer Source } \\
\text { Medicare } \\
\text { Medicaid } \\
\text { Tricare } \\
\text { Department of Veteran Affairs } \\
\text { Worker's Compensation } \\
\text { Other Government Funding } \\
\text { Private Insurance } \\
\text { Long-Term Care Insurance } \\
\text { Self-Pay } \\
\text { No Charge for Care } \\
\text { Undetermined Payer Source } \\
\text { Other }\end{array}$ & $\begin{array}{l}76.7 \% \\
7.4 \% \\
.2 \% \\
1.9 \% \\
0 \% \\
.4 \% \\
6.8 \% \\
.2 \% \\
1 \% \\
1 \% \\
0 \% \\
1.4 \%\end{array}$ & 73.091 & 42 & $.002 *$ \\
\hline
\end{tabular}

$* p$ values $\leq .05$ 
Table 11

Patient Resource Referral Service Utilization Age at Discharge, Gender, Race, Ethnicity, Marital Status, \& Veteran Status

\begin{tabular}{|c|c|c|c|c|}
\hline & $\%$ of Those Who Used the Service & $\chi^{2}$ & df & $p$ \\
\hline Patient Age at Discharge & Average age of 74 & 184.655 & 150 & $.020^{*}$ \\
\hline $\begin{array}{l}\text { Gender } \\
\text { Male } \\
\text { Female } \\
\end{array}$ & N.S. & .156 & 3 & .984 \\
\hline $\begin{array}{l}\text { Race } \\
\text { American Indian or Alaskan Native } \\
\text { Asian } \\
\text { Native Hawaiian or other Pacific Islander } \\
\text { Black or African American } \\
\text { White }\end{array}$ & $\begin{array}{l}\text { N.S } \\
1.1 \% \\
\text { N.S. } \\
\text { N.S. } \\
\text { N.S. }\end{array}$ & $\begin{array}{c}7.177 \\
20.426 \\
2.290 \\
2.950 \\
1.618 \\
\end{array}$ & $\begin{array}{l}3 \\
3 \\
3 \\
3 \\
3\end{array}$ & $\begin{array}{l}.066 \\
.000^{*} \\
.514 \\
.399 \\
.655 \\
\end{array}$ \\
\hline $\begin{array}{l}\text { Ethnicity } \\
\text { Hispanic or Latino } \\
\text { White Non-Hispanic or Latino } \\
\text { Black Non-Hispanic or Latino } \\
\text { Other Non-Hispanic or Latino } \\
\end{array}$ & $\begin{array}{c}187.752 \\
3.3 \% \\
85.2 \% \\
9.5 \% \\
1.4 \% \\
\end{array}$ & 187.752 & 12 & $.000^{*}$ \\
\hline $\begin{array}{l}\text { Marital Status } \\
\text { Married } \\
\text { Widowed } \\
\text { Divorced } \\
\text { Separated } \\
\text { Never Married } \\
\text { Living with a Partner }\end{array}$ & $\begin{array}{c}42.2 \% \\
35.6 \% \\
7 \% \\
1 \% \\
9.7 \% \\
.8 \% \\
\end{array}$ & 40.254 & 18 & $.002 *$ \\
\hline Veteran & $11.9 \%$ & 32.692 & 9 & $.000 *$ \\
\hline
\end{tabular}

$* p$ values $\leq .05$ 
Table 12

Patient Resource Referral Service Utilization Caregiver Status, \& Household Membership

\begin{tabular}{|c|c|c|c|c|}
\hline & $\%$ of Those Who Used the Service & $\chi^{2}$ & $d f$ & $p$ \\
\hline Caregiver & $86.1 \%$ & 414.058 & 6 & $.000 *$ \\
\hline $\begin{array}{l}\text { Identification of the Caregiver } \\
\text { Spouse } \\
\text { Child } \\
\text { Parent } \\
\text { Other family Member } \\
\text { Non-Family Member }\end{array}$ & $\begin{array}{c}32.1 \% \\
30 \% \\
3.9 \% \\
11.5 \% \\
14.2 \%\end{array}$ & 32.308 & 18 & $.020 *$ \\
\hline $\begin{array}{l}\text { Household Membership } \\
\text { Alone } \\
\text { Family }\end{array}$ & $\begin{array}{l}14.6 \% \\
59.9 \%\end{array}$ & 25.359 & 15 & $.045^{*}$ \\
\hline $\begin{array}{l}\text { Spouse or Significant Other } \\
\text { Parent } \\
\text { Child } \\
\text { Other Family Members }\end{array}$ & $\begin{array}{l}\text { N.S. } \\
\text { N.S. } \\
\text { N.S. } \\
10 \%\end{array}$ & $\begin{array}{c}7.753 \\
7.517 \\
7.630 \\
10.568\end{array}$ & $\begin{array}{l}3 \\
3 \\
3 \\
3\end{array}$ & $\begin{array}{l}.051 \\
.057 \\
.054 \\
.044^{*}\end{array}$ \\
\hline $\begin{array}{l}\text { Non-Family Members } \\
\text { Family and Non-Family }\end{array}$ & $\begin{array}{c}3.9 \% \\
.4 \%\end{array}$ & & & \\
\hline
\end{tabular}

$* p$ values $\leq .05$ 
Patient Resource Referral Service Utilization \& Patient Location at the Beginning as Well as End of Care

\begin{tabular}{|c|c|c|c|c|}
\hline & $\%$ of Those Who Used the Service & $\chi^{2}$ & $d f$ & $p$ \\
\hline $\begin{array}{l}\text { Location at the Beginning of Care } \\
\text { Private Home } \\
\text { Nursing Home/Skilled Nursing Facility } \\
\text { Hospital } \\
\text { Residential Care Place } \\
\text { Agency Inpatient/Residential Facility } \\
\text { Other }\end{array}$ & $\begin{array}{c}53.3 \% \\
11.7 \% \\
4.7 \% \\
2.5 \% \\
5.1 \% \\
.4 \%\end{array}$ & 922.022 & 21 & $.000 *$ \\
\hline $\begin{array}{l}\text { Location at the End of Care } \\
\text { Private Home } \\
\text { Nursing Home/Skilled Nursing Facility } \\
\text { Hospital } \\
\text { Residential Care Place } \\
\text { Agency Inpatient/Residential Facility } \\
\text { Other }\end{array}$ & $\begin{array}{c}45.3 \% \\
17.1 \% \\
5.3 \% \\
2.3 \% \\
6.8 \% \\
1 \%\end{array}$ & 913.969 & 21 & $.000 *$ \\
\hline
\end{tabular}

$* p$ values $\leq .05$ 
Mental health services. Overall, 1.3\% of hospice patients utilized mental health services. The majority of the patients who used this service had a schizophrenic disorder (19\%). Cognitive status was not significant. Patients with no ADL needs represented the most patients that used this service (35.7\%). Patient level of care was not significant. Patients who used mental health services had an average length of 100 service days. Medicare patients represented $40.5 \%$ of those who used this service. Patients who used this service had the average age of 73 years old. Patient gender, racial identity, and ethnicity were not significant. Married patients accounted for $28.6 \%$ of patients who used this service. Patient veteran status was not significant. Results indicated that $73.8 \%$ of patients who used mental health services had a caregiver. Those with a spousal caregiver represented 23.8\% of patients who used this service. Household membership as well as patient location at the beginning and end of care was insignificant. (see Tables 14-18) 
Patient Utilization of Mental Health Services Based on Primary Diagnosis, Cognitive Status, \& Total ADL Needs

\begin{tabular}{|c|c|c|c|c|}
\hline & $\%$ of Those Who Used the Service & $\chi^{2}$ & df & $p$ \\
\hline $\begin{array}{l}\text { Diagnosis } \\
\text { Schizophrenic disorders } \\
\text { Lung, Bronchial, or Tracheal Cancer } \\
\text { Heart Failure }\end{array}$ & $\begin{array}{l}19 \% \\
7.1 \% \\
7.1 \%\end{array}$ & 426.569 & 229 & $.000^{*}$ \\
\hline $\begin{array}{l}\text { Cognitive Status } \\
\text { No Cognitive Impairment } \\
\text { Occasional Reminders } \\
\text { Some Assistance } \\
\text { Great Deal of Assistance } \\
\text { Severe Cognitive Impairment }\end{array}$ & N.S. & 3.864 & 6 & .695 \\
\hline $\begin{array}{l}\text { Patient Total ADL Needs } \\
\text { None } \\
\text { One } \\
\text { Two } \\
\text { Three } \\
\text { Four } \\
\text { Five }\end{array}$ & $\begin{array}{c}35.7 \% \\
2.4 \% \\
4.8 \% \\
14.3 \% \\
14.3 \% \\
19 \%\end{array}$ & 24.298 & 7 & $.001^{*}$ \\
\hline
\end{tabular}

$* p$ values $\leq .05$ 
Table 15

Patient Utilization of Mental Health Services Based on Level of Care, Length of Service, \& Payer Source

\begin{tabular}{|c|c|c|c|c|}
\hline & $\%$ of Those Who Used the Service & $\chi^{2}$ & df & $p$ \\
\hline $\begin{array}{l}\text { Level of Care } \\
\text { Routine Homecare } \\
\text { Continuous Home Care } \\
\text { General Inpatient } \\
\text { Inpatient Respite }\end{array}$ & N.S. & 1.169 & 6 & .978 \\
\hline Length of Service & Average 100 days & 639.575 & 293 & $.000 *$ \\
\hline $\begin{array}{l}\text { Payer Source } \\
\text { Medicare } \\
\text { Medicaid } \\
\text { Tricare } \\
\text { Department of Veteran Affairs } \\
\text { Worker's Compensation } \\
\text { Other Government Funding } \\
\text { Private Insurance } \\
\text { Long-Term Care Insurance } \\
\text { Self-Pay } \\
\text { No Charge for Care } \\
\text { Undetermined Payer Source } \\
\text { Other }\end{array}$ & $\begin{array}{c}40.5 \% \\
31 \% \\
0 \% \\
7.1 \% \\
0 \% \\
2.4 \% \\
2.4 \% \\
0 \% \\
0 \% \\
9.5 \% \\
0 \% \\
0 \%\end{array}$ & 56.392 & 14 & $.000 *$ \\
\hline
\end{tabular}

$* p$ values $\leq .05$ 
Table 16

Patient Mental Health Service Utilization, Age at Discharge, Gender, Race, Ethnicity, Marital Status, \& Veteran Status

\begin{tabular}{|c|c|c|c|c|}
\hline & $\%$ of Those Who Used the Service & $\chi^{2}$ & df & $p$ \\
\hline Patient Age at Discharge & Average 73 years old & 234.926 & 75 & $.000 *$ \\
\hline $\begin{array}{l}\text { Gender } \\
\text { Male } \\
\text { Female } \\
\end{array}$ & N.S. & .001 & 1 & .969 \\
\hline $\begin{array}{l}\text { Race } \\
\text { American Indian or Alaskan Native } \\
\text { Asian } \\
\text { Native Hawaiian or other Pacific Islander } \\
\text { Black or African American } \\
\text { White } \\
\end{array}$ & $\begin{array}{l}\text { N.S. } \\
\text { N.S. } \\
\text { N.S. } \\
\text { N.S. } \\
\text { N.S. }\end{array}$ & $\begin{array}{l}1.720 \\
.429 \\
.124 \\
1.036 \\
.988 \\
\end{array}$ & $\begin{array}{l}1 \\
1 \\
1 \\
1 \\
1\end{array}$ & $\begin{array}{l}.190 \\
.512 \\
.724 \\
.309 \\
.320 \\
\end{array}$ \\
\hline $\begin{array}{l}\text { Ethnicity } \\
\text { Hispanic or Latino } \\
\text { White Non-Hispanic or Latino } \\
\text { Black Non-Hispanic or Latino } \\
\text { Other Non-Hispanic or Latino } \\
\end{array}$ & N.S. & 2.516 & 4 & .642 \\
\hline $\begin{array}{l}\text { Marital Status } \\
\text { Married } \\
\text { Widowed } \\
\text { Divorced } \\
\text { Separated } \\
\text { Never Married } \\
\text { Living with a Partner } \\
\end{array}$ & $\begin{array}{l}28.6 \% \\
26.2 \% \\
9.5 \% \\
2.4 \% \\
19 \% \\
2.4 \% \\
\end{array}$ & 12.733 & 6 & .047 \\
\hline Veteran & N.S. & 1.202 & 3 & .753 \\
\hline
\end{tabular}


$* p$ values $\leq .05$

\section{Table 17}

Patient Mental Health Service Utilization, Caregiver Status, \& Household Membership

\begin{tabular}{|c|c|c|c|c|}
\hline & $\%$ of Those Who Used the Service & $\chi^{2}$ & $d f$ & $p$ \\
\hline Caregiver & $73.8 \%$ & 7.863 & 2 & $.020^{*}$ \\
\hline $\begin{array}{l}\text { Identification of the Caregiver } \\
\text { Spouse } \\
\text { Child } \\
\text { Parent } \\
\text { Other family Member } \\
\text { Non-Family Member }\end{array}$ & $\begin{array}{c}23.8 \% \\
19 \% \\
9.5 \% \\
9.5 \% \\
9.5 \% \\
\end{array}$ & 21.562 & 6 & $.001^{*}$ \\
\hline $\begin{array}{l}\text { Household Membership } \\
\text { Alone } \\
\text { Family }\end{array}$ & N.S. & 3.929 & 5 & .560 \\
\hline $\begin{array}{l}\text { Spouse or Significant Other } \\
\text { Parent } \\
\text { Child } \\
\text { Other Family Members }\end{array}$ & $\begin{array}{l}\text { N.S. } \\
\text { N.S. } \\
\text { N.S. } \\
\text { N.S. }\end{array}$ & $\begin{array}{c}2.111 \\
6.104 \\
.872 \\
1.319\end{array}$ & $\begin{array}{l}3 \\
3 \\
3 \\
3\end{array}$ & $\begin{array}{l}.550 \\
.107 \\
.832 \\
.725\end{array}$ \\
\hline $\begin{array}{l}\text { Non-Family Members } \\
\text { Family and Non-Family }\end{array}$ & & & & \\
\hline
\end{tabular}


Table 18

Patient Mental Health Service Utilization \& Patient Location at the Beginning as Well as End of Care

\begin{tabular}{|c|c|c|c|c|}
\hline & $\%$ of Those Who Used the Service & $\chi^{2}$ & $d f$ & $p$ \\
\hline $\begin{array}{l}\text { Location at the Beginning of Care } \\
\text { Private Home } \\
\text { Nursing Home/Skilled Nursing Facility } \\
\text { Hospital } \\
\text { Residential Care Place } \\
\text { Agency Inpatient/Residential Facility } \\
\text { Other }\end{array}$ & N.S. & 6.715 & 7 & .459 \\
\hline $\begin{array}{l}\text { Location at the End of Care } \\
\text { Private Home } \\
\text { Nursing Home/Skilled Nursing Facility } \\
\text { Hospital } \\
\text { Residential Care Place } \\
\text { Agency Inpatient/Residential Facility } \\
\text { Other }\end{array}$ & N.S. & 1.237 & 7 & .990 \\
\hline
\end{tabular}

$* p$ values $\leq .05$ 
Respite care services. Overall, 4.6\% of patients used respite services. Patient diagnosis, cognitive status, and total ADL needs were not significantly related to respite care service use. Hospice patients under routine home care represented $74.3 \%$ of patients that used respite services. Patients who used this service had an average length of 120 service days. Medicare patients represented 63.5\% of those who used this service. Patient age and gender were not significantly related to respite care service use. The only significantly related racial identity to respite care use was Black or African American racial identity. Patients that identified as Black or African American represented 12.2\% of patients who used this service. Patient ethnicity was not significant. Married patients accounted for $50.7 \%$ of patients who used this service and veterans represented $16.2 \%$.

Results indicated that $96.6 \%$ of patients who used respite services had a caregiver. Patients with a spousal caregiver represented $43.2 \%$ of patients who used this service. Patients who lived with a family member accounted for most of the patients who used this service (81.1\%). More specifically, those who had household membership with their spouse represented $48 \%$ of those who lived with a family member. Patients that lived in a private home at the beginning of care accounted for $80.4 \%$. At the end of care, patients that lived in a private home also represented the most of the patients that used respite services (62.2\%). (see Tables 19- 23) 
Patient Utilization of Respite Services Based on Primary Diagnosis, Cognitive Status, \& Total ADL Needs

\begin{tabular}{|c|c|c|c|c|}
\hline & $\%$ of Those Who Used the Service & $\chi^{2}$ & $\mathrm{df}$ & $p$ \\
\hline $\begin{array}{l}\text { Diagnosis } \\
\text { Lung, Bronchial, or Tracheal Cancer } \\
\text { Heart Failure } \\
\text { Unspecified Chronic Airway Obstruction } \\
\text { Unknown Cause of Morbidity }\end{array}$ & N.S. & 186.962 & 229 & .981 \\
\hline $\begin{array}{l}\text { Cognitive Status } \\
\text { No Cognitive Impairment } \\
\text { Occasional Reminders } \\
\text { Some Assistance } \\
\text { Great Deal of Assistance } \\
\text { Severe Cognitive Impairment }\end{array}$ & N.S. & 6.834 & 6 & .337 \\
\hline $\begin{array}{l}\text { Patient Total ADL Needs } \\
\text { None } \\
\text { One } \\
\text { Two } \\
\text { Three } \\
\text { Four } \\
\text { Five }\end{array}$ & N.S. & 10.419 & 7 & .166 \\
\hline
\end{tabular}


Table 20

Patient Utilization of Respite Services Based on Level of Care, Length of Service, \& Payer Source

\begin{tabular}{|c|c|c|c|c|}
\hline & $\%$ of Those Who Used the Service & $\chi^{2}$ & df & $p$ \\
\hline $\begin{array}{l}\text { Level of Care } \\
\text { Routine Homecare } \\
\text { Continuous Home Care } \\
\text { General Inpatient } \\
\text { Inpatient Respite }\end{array}$ & $\begin{array}{c}74.3 \% \\
2 \% \\
6.1 \% \\
5.4 \%\end{array}$ & 99.406 & 6 & $.000 *$ \\
\hline Length of Service & Average 120 days & 833.567 & 293 & $.000 *$ \\
\hline $\begin{array}{l}\text { Payer Source } \\
\text { Medicare } \\
\text { Medicaid } \\
\text { Tricare } \\
\text { Department of Veteran Affairs } \\
\text { Worker's Compensation } \\
\text { Other Government Funding } \\
\text { Private Insurance } \\
\text { Long-Term Care Insurance } \\
\text { Self-Pay } \\
\text { No Charge for Care } \\
\text { Undetermined Payer Source } \\
\text { Other }\end{array}$ & $\begin{array}{c}63.5 \% \\
5.1 \% \\
0 \% \\
1.4 \% \\
0 \% \\
.7 \% \\
8.2 \% \\
0 \% \\
2 \% \\
10.1 \% \\
0 \% \\
.7 \%\end{array}$ & 89.947 & 14 & $.000 *$ \\
\hline
\end{tabular}

$* p$ values $\leq .05$ 
Table 21

Patient Respite Service Utilization, Age at Discharge, Gender, Race, Ethnicity, Marital Status, \& Veteran Status

\begin{tabular}{|c|c|c|c|c|}
\hline & $\%$ of Those Who Used the Service & $\chi^{2}$ & df & $p$ \\
\hline Patient Age at Discharge & N.S. & 85.396 & 75 & .193 \\
\hline $\begin{array}{l}\text { Gender } \\
\text { Male } \\
\text { Female }\end{array}$ & N.S. & 1.107 & 1 & .293 \\
\hline $\begin{array}{l}\text { Race } \\
\text { American Indian or Alaskan Native } \\
\text { Asian } \\
\text { Native Hawaiian or other Pacific Islander } \\
\text { Black or African American } \\
\text { White } \\
\end{array}$ & $\begin{array}{l}\text { N.S. } \\
\text { N.S. } \\
\text { N.S. } \\
12.2 \% \\
\text { N.S. }\end{array}$ & $\begin{array}{l}.002 \\
1.583 \\
.458 \\
4.310 \\
1.680 \\
\end{array}$ & $\begin{array}{l}1 \\
1 \\
1 \\
1 \\
1\end{array}$ & $\begin{array}{l}.966 \\
.208 \\
.498 \\
.038^{*} \\
.195 \\
\end{array}$ \\
\hline $\begin{array}{l}\text { Ethnicity } \\
\text { Hispanic or Latino } \\
\text { White Non-Hispanic or Latino } \\
\text { Black Non-Hispanic or Latino } \\
\text { Other Non-Hispanic or Latino } \\
\end{array}$ & N.S. & 6.863 & 4 & .143 \\
\hline $\begin{array}{l}\text { Marital Status } \\
\text { Married } \\
\text { Widowed } \\
\text { Divorced } \\
\text { Separated } \\
\text { Never Married } \\
\text { Living with a Partner }\end{array}$ & $\begin{array}{c}50.7 \% \\
32.4 \% \\
4.1 \% \\
2.7 \% \\
6.8 \% \\
.7 \% \\
\end{array}$ & 19.506 & 6 & $.003 *$ \\
\hline Veteran & $16.2 \%$ & 12.469 & 3 & $.006 *$ \\
\hline
\end{tabular}


Table 22

Patient Respite Service Utilization, Caregiver Status, \& Household Membership

\begin{tabular}{|c|c|c|c|c|}
\hline & $\%$ of Those Who Used the Service & $\chi^{2}$ & $d f$ & $p$ \\
\hline Caregiver & $96.6 \%$ & 13.484 & 2 & $.000 *$ \\
\hline $\begin{array}{l}\text { Identification of the Caregiver } \\
\text { Spouse } \\
\text { Child } \\
\text { Parent } \\
\text { Other family Member } \\
\text { Non-Family Member } \\
\end{array}$ & $\begin{array}{c}43.2 \% \\
30.4 \% \\
4.7 \% \\
10.1 \% \\
8.1 \% \\
\end{array}$ & 25.372 & 6 & $.000^{*}$ \\
\hline $\begin{array}{l}\text { Household Membership } \\
\text { Alone } \\
\text { Family }\end{array}$ & $\begin{array}{c}9.5 \% \\
81.1 \%\end{array}$ & 43.886 & 5 & $.000 *$ \\
\hline $\begin{array}{l}\text { Spouse or Significant Other } \\
\text { Parent } \\
\text { Child } \\
\text { Other Family Members }\end{array}$ & $\begin{array}{c}48 \% \\
4 \% \\
23 \% \\
8 \%\end{array}$ & $\begin{array}{l}33.805 \\
24.078 \\
26.443 \\
23.936\end{array}$ & $\begin{array}{l}3 \\
3 \\
3 \\
3\end{array}$ & $\begin{array}{l}.000^{*} \\
.000^{*} \\
.000^{*} \\
.000 *\end{array}$ \\
\hline $\begin{array}{l}\text { Non-Family Members } \\
\text { Family and Non-Family }\end{array}$ & $\begin{array}{c}3.4 \% \\
0 \%\end{array}$ & & & \\
\hline
\end{tabular}

$* p$ values $\leq .05$ 
Table 23

Patient Respite Utilization \& Patient Location at the Beginning as Well as End of Care

\begin{tabular}{|l|c|c|c|}
\hline & \% of Those Who Used the Service & $\chi^{2}$ & $d f$ \\
\hline Location at the Beginning of Care & & 115.882 & 7 \\
Private Home & $80.4 \%$ & $.000^{*}$ \\
Nursing Home/Skilled Nursing Facility & $2 \%$ & \\
Hospital & $2 \%$ & \\
Residential Care Place & $0 \%$ & \\
Agency Inpatient/Residential Facility & $2.7 \%$ & \\
Other & $1.4 \%$ & 71.110 & \\
\hline Location at the End of Care & & \\
Private Home & $62.2 \%$ & $.000^{*}$ \\
Nursing Home/Skilled Nursing Facility & $12.2 \%$ & \\
Hospital & $9.5 \%$ & \\
Residential Care Place & $1.4 \%$ & & \\
Agency Inpatient/Residential Facility & $2 \%$ & & \\
Other & $1.4 \%$ & & \\
\end{tabular}

$* p$ values $\leq .05$ 
Ethical issues counseling. Overall, 3.9\% of patients utilized ethical issues counseling. Patient diagnosis, cognitive status, and total ADL needs were insignificantly related to use of ethical issues counseling. Hospice patients under routine home care represented $83.3 \%$ of patients that used ethical issues counseling. Patients who used this service had an average length of 110 service days. Medicare patients represented 68.3\% of those who used this service. Patient age and gender were not significant. Only White and Black or African American racial identity yielded significant results. White patients used this service the most (82.5\%). Furthermore, White non-Hispanics represented the highest amount of patients that used ethical issues counseling. Patient marital and veteran statuses were not significant.

Caregiver status was also insignificantly related to ethical issues counseling utilization. Those with a spousal caregiver represented 38.9\% of patients who used this service. Patient household membership was not significant. Patients that lived in a private home at the beginning of care accounted for $72.2 \%$. At the end of care, patients that lived in a private home also represented the most of the patients that used medical social services (61.9\%). (see Table 24- 28) 
Table 24

Patient Utilization of Ethical Issues Counseling Based on Primary Diagnosis, Cognitive Status, \& Total ADL Needs

\begin{tabular}{|c|c|c|c|c|}
\hline & $\%$ of Those Who Used the Service & $\chi^{2}$ & $\mathrm{df}$ & $p$ \\
\hline $\begin{array}{l}\text { Diagnosis } \\
\text { Lung, Bronchial, or Tracheal Cancer } \\
\text { Heart Failure } \\
\text { Unspecified Chronic Airway Obstruction } \\
\text { Unknown Cause of Morbidity }\end{array}$ & N.S. & 175.356 & 229 & .997 \\
\hline $\begin{array}{l}\text { Cognitive Status } \\
\text { No Cognitive Impairment } \\
\text { Occasional Reminders } \\
\text { Some Assistance } \\
\text { Great Deal of Assistance } \\
\text { Severe Cognitive Impairment }\end{array}$ & N.S. & 11.264 & 6 & .081 \\
\hline $\begin{array}{l}\text { Patient Total ADL Needs } \\
\text { None } \\
\text { One } \\
\text { Two } \\
\text { Three } \\
\text { Four } \\
\text { Five }\end{array}$ & N.S. & 13.476 & 7 & .061 \\
\hline
\end{tabular}

$* p$ values $\leq .05$ 
Table 25

Patient Utilization of Ethical Issues Counseling Based on Level of Care, Length of Service, \& Payer Source

\begin{tabular}{|l|c|c|c|}
\hline & \% of Those Who Used the Service & $\chi^{2}$ & df \\
\hline Level of Care & & 75.306 & 6 \\
Routine Homecare & $83.3 \%$ & $.000^{*}$ \\
Continuous Home Care & $2.4 \%$ & \\
General Inpatient & $8.7 \%$ & \\
Inpatient Respite & $2.4 \%$ & 806.055 & 293 \\
\hline Length of Service & Average 110 days & $.000^{*}$ \\
\hline Payer Source & & 28.765 & \\
Medicare & $68.3 \%$ & $.011^{*}$ \\
Medicaid & $9.5 \%$ & \\
Tricare & $0 \%$ & \\
Department of Veteran Affairs & $0 \%$ & \\
Worker's Compensation & $0 \%$ & \\
Other Government Funding & $0 \%$ & \\
Private Insurance & $9.5 \%$ & \\
Long-Term Care Insurance & $0 \%$ & \\
Self-Pay & $2 \%$ & \\
No Charge for Care & $2.4 \%$ & \\
Undetermined Payer Source & $0 \%$ & \\
Other & $2.4 \%$ & \\
\hline
\end{tabular}

$* p$ values $\leq .05$ 
Table 26

Patient Ethical Issues Counseling Utilization, Age at Discharge, Gender, Race, Ethnicity, Marital Status, \& Veteran Status

\begin{tabular}{|c|c|c|c|c|}
\hline & $\%$ of Those Who Used the Service & $\chi^{2}$ & df & $p$ \\
\hline Patient Age at Discharge & N.S. & 77.083 & 75 & .412 \\
\hline $\begin{array}{l}\text { Gender } \\
\text { Male } \\
\text { Female }\end{array}$ & N.S. & .983 & 1 & .322 \\
\hline $\begin{array}{l}\text { Race } \\
\text { American Indian or Alaskan Native } \\
\text { Asian } \\
\text { Native Hawaiian or other Pacific Islander } \\
\text { Black or African American } \\
\text { White }\end{array}$ & $\begin{array}{l}\text { N.S. } \\
\text { N.S. } \\
\text { N.S. } \\
15.9 \% \\
82.5 \% \\
\end{array}$ & $\begin{array}{c}.015 \\
.054 \\
.386 \\
12.299 \\
8.911 \\
\end{array}$ & $\begin{array}{l}1 \\
1 \\
1 \\
1 \\
1\end{array}$ & $\begin{array}{l}.902 \\
.816 \\
.534 \\
.000^{*} \\
.003^{*}\end{array}$ \\
\hline $\begin{array}{l}\text { Ethnicity } \\
\text { Hispanic or Latino } \\
\text { White Non-Hispanic or Latino } \\
\text { Black Non-Hispanic or Latino } \\
\text { Other Non-Hispanic or Latino } \\
\end{array}$ & $\begin{array}{c}.8 \% \\
80.2 \% \\
15.9 \% \\
1.6 \% \\
\end{array}$ & 16.288 & 4 & $.003^{*}$ \\
\hline $\begin{array}{l}\text { Marital Status } \\
\text { Married } \\
\text { Widowed } \\
\text { Divorced } \\
\text { Separated } \\
\text { Never Married } \\
\text { Living with a Partner } \\
\end{array}$ & N.S. & 5.799 & 6 & .448 \\
\hline Veteran & N.S. & 6.280 & 3 & .099 \\
\hline
\end{tabular}

$* p$ values $\leq .05$ 
Table 27

Patient Ethical Issues Counseling Utilization, Caregiver Status, \& Household Membership

\begin{tabular}{|c|c|c|c|c|}
\hline & $\%$ of Those Who Used the Service & $\chi^{2}$ & $d f$ & $p$ \\
\hline Caregiver & N.S. & 5.438 & 2 & .066 \\
\hline $\begin{array}{l}\text { Identification of the Caregiver } \\
\text { Spouse } \\
\text { Child } \\
\text { Parent } \\
\text { Other family Member } \\
\text { Non-Family Member }\end{array}$ & $\begin{array}{c}38.9 \% \\
34.9 \% \\
2.4 \% \\
7.1 \% \\
10.3 \% \\
\end{array}$ & 13.056 & 6 & $.042 *$ \\
\hline $\begin{array}{l}\text { Household Membership } \\
\text { Alone } \\
\text { Family }\end{array}$ & N.S. & 2.839 & 5 & .725 \\
\hline $\begin{array}{l}\text { Spouse or Significant Other } \\
\text { Parent } \\
\text { Child } \\
\text { Other Family Members }\end{array}$ & $\begin{array}{l}\text { N.S. } \\
\text { N.S. } \\
\text { N.S. } \\
\text { N.S. }\end{array}$ & $\begin{array}{l}2.553 \\
3.172 \\
4.399 \\
2.345\end{array}$ & $\begin{array}{l}3 \\
3 \\
3 \\
3\end{array}$ & $\begin{array}{l}.466 \\
.366 \\
.221 \\
.504\end{array}$ \\
\hline $\begin{array}{l}\text { Non-Family Members } \\
\text { Family and Non-Family }\end{array}$ & & & & \\
\hline
\end{tabular}

$* p$ values $\leq .05$ 
Table 28

Patient Ethical Issues Counseling Utilization \& Patient Location at the Beginning as Well as End of Care

\begin{tabular}{|c|c|c|c|c|}
\hline & $\%$ of Those Who Used the Service & $\chi^{2}$ & $d f$ & $p$ \\
\hline $\begin{array}{l}\text { Location at the Beginning of Care } \\
\text { Private Home } \\
\text { Nursing Home/Skilled Nursing Facility } \\
\text { Hospital } \\
\text { Residential Care Place } \\
\text { Agency Inpatient/Residential Facility } \\
\text { Other }\end{array}$ & $\begin{array}{c}72.2 \% \\
12.7 \% \\
7.1 \% \\
3.2 \% \\
1.6 \% \\
.8 \%\end{array}$ & 80.614 & 7 & $.000^{*}$ \\
\hline $\begin{array}{l}\text { Location at the End of Care } \\
\text { Private Home } \\
\text { Nursing Home/Skilled Nursing Facility } \\
\text { Hospital } \\
\text { Residential Care Place } \\
\text { Agency Inpatient/Residential Facility } \\
\text { Other }\end{array}$ & $\begin{array}{c}61.9 \% \\
18.3 \% \\
5.6 \% \\
4 \% \\
4.8 \% \\
3.2 \%\end{array}$ & 80.578 & 7 & $.000^{*}$ \\
\hline
\end{tabular}

$* p$ values $\leq .05$ 
Advanced directive status and psychosocial service utilization. Overall, $67.6 \%$ of patients had advanced directives. The majority of the patients who had advanced directives had cancer, specifically either the lung, bronchial, or tracheal form of the disease (11.6\%). Those with no cognitive impairment had advanced directives the most (31.2\%). Patients with four total ADL needs represented the most patients with advanced directives (24.9\%). Hospice patients under routine home care represented $65.2 \%$ of patients that with advanced directives. Patients with advanced directives had an average length of 60 service days. Medicare patients represented 77.6\% of those who had advanced directives.

Patients with advanced directives had the average age of 75 years old. Patient gender was not significant. Native Hawaiian or other Pacific Islander, White, or Black or African American racial identities were the only ones significantly related to advanced directive status. White patients represented the largest racial group that had advanced directives (93.6\%). Furthermore, White non-Hispanics represented the highest amount of patients that had advanced directives (88.5\%). Married patients accounted for $41.9 \%$ of patients who had advanced directives and veterans represented $10.9 \%$.

Of the patients with advanced directives, those with caregivers represented $89.5 \%$. Those with a spousal caregiver represented $32.2 \%$ of patients with advanced directives. Patients who lived with a family member accounted for most of the patients with advanced directives (51.5\%). More specifically, those who had household membership with their spouse represented 31\% of those who lived with a family member. Patients that lived in a private home at the beginning of care accounted for $49.4 \%$. At the 
end of care, patients that lived in a private home also represented the most of the patients that had advanced directives (43.4\%).

As it pertains to patient utilization of medical social service based on advanced directive status, those in possession of advanced directives represented $70 \%$. Patients with advanced directives had an average of 3.25 visits while under hospice care. Use of resource referral and mental health services were not significantly related to advanced directive status. Patients with advanced directives represented $7.4 \%$ of patients who used respite care services. Of those who used ethical issues counseling, 6.3\% had advanced directives. Use of interpreter, homemaker, transportation, and Meals on Wheels services was not significant. Patients with advanced directives represented $4.4 \%$ of those who used CAM services. Of the patients who used pastoral care services, 54.9\% had advanced directives while those with advanced directives represented $25.8 \%$ of patients who used volunteer services.

Of the patients with caregivers who used bereavement services, $71 \%$ had advanced directives. Results indicated that of the patients with caregivers who used caregiver health and wellness services, $26.7 \%$ had advanced directives. Of the patients with care givers that used spiritual care services, 56\% had advanced directives. Caregiver use of safety training services was not significant. Among the patients with caregivers that used suspected abuse or neglect services, $5 \%$ had advanced directives. Of those with caregivers that used resource referral information services, 22\% had advanced directives. (see Tables 29- 35) 
Table 29

Patient Advanced Directive Status, Primary Diagnosis, Cognitive Status, \& Total ADL Needs

\begin{tabular}{|c|c|c|c|c|}
\hline & \% of Those With Advanced Directives & $\chi^{2}$ & df & $p$ \\
\hline $\begin{array}{l}\text { Diagnosis } \\
\text { Lung, Bronchial, or Tracheal Cancer } \\
\text { Heart Failure } \\
\text { Unspecified Chronic Airway Obstruction } \\
\text { Organic Psychotic Chronic Conditions } \\
\text { Other Forms of Chronic Ischemic Heart Disease }\end{array}$ & $\begin{array}{l}11.6 \% \\
6.9 \% \\
5.6 \% \\
5.1 \% \\
5.6 \% \\
\end{array}$ & 772.035 & 229 & $.000 *$ \\
\hline $\begin{array}{l}\text { Cognitive Status } \\
\text { No Cognitive Impairment } \\
\text { Occasional Reminders } \\
\text { Some Assistance } \\
\text { Great Deal of Assistance } \\
\text { Severe Cognitive Impairment }\end{array}$ & $\begin{array}{l}31.2 \% \\
15 \% \\
15 \% \\
18.9 \% \\
10.7 \% \\
\end{array}$ & 117.244 & 6 & $.000 *$ \\
\hline $\begin{array}{l}\text { Patient Total ADL Needs } \\
\text { None } \\
\text { One } \\
\text { Two } \\
\text { Three } \\
\text { Four } \\
\text { Five }\end{array}$ & $\begin{array}{l}9.7 \% \\
8.9 \% \\
9.1 \% \\
18.6 \% \\
24.9 \% \\
20.8 \%\end{array}$ & 80.824 & 7 & $.000 *$ \\
\hline
\end{tabular}

$* p$ values $\leq .05$ 
Patient Advanced Directive Status, Level of Care, Length of Service, \& Payer Source

\begin{tabular}{|c|c|c|c|c|}
\hline & $\%$ of Those With Advanced Directives & $\chi^{2}$ & df & $p$ \\
\hline $\begin{array}{l}\text { Level of Care } \\
\text { Routine Homecare } \\
\text { Continuous Home Care } \\
\text { General Inpatient } \\
\text { Inpatient Respite } \\
\end{array}$ & $\begin{array}{c}65.2 \% \\
3.2 \% \\
13.9 \% \\
.9 \% \\
\end{array}$ & 790.179 & 6 & $\begin{array}{c}.000 \\
*\end{array}$ \\
\hline Length of Service & Average 60 days & 938.098 & 293 & $\begin{array}{c}.000 \\
*\end{array}$ \\
\hline $\begin{array}{l}\text { Payer Source } \\
\text { Medicare } \\
\text { Medicaid } \\
\text { Tricare } \\
\text { Department of Veteran Affairs } \\
\text { Worker's Compensation } \\
\text { Other Government Funding } \\
\text { Private Insurance } \\
\text { Long-Term Care Insurance } \\
\text { Self-Pay } \\
\text { No Charge for Care } \\
\text { Undetermined Payer Source } \\
\text { Other }\end{array}$ & $\begin{array}{l}77.6 \% \\
5.5 \% \\
.2 \% \\
1.7 \% \\
.1 \% \\
.4 \% \\
7.5 \% \\
.2 \% \\
3 \% \\
1.1 \% \\
.1 \% \\
.4 \%\end{array}$ & 244.391 & 14 & $\begin{array}{c}.000 \\
*\end{array}$ \\
\hline
\end{tabular}

$* p$ values $\leq .05$ 
Table 31

Patient Advanced Directive Status, Age at Discharge, Gender, Race, Ethnicity, Marital Status, \& Veteran Status

\begin{tabular}{|c|c|c|c|c|}
\hline & $\%$ of Those With Advanced Directives & $\chi^{2}$ & df & $p$ \\
\hline Patient Age at Discharge & Average Age of 75 & 136.332 & 75 & $.000 *$ \\
\hline $\begin{array}{l}\text { Gender } \\
\text { Male } \\
\text { Female }\end{array}$ & N.S. & 905 & 1 & .341 \\
\hline $\begin{array}{l}\text { Race } \\
\text { American Indian or Alaskan Native } \\
\text { Asian } \\
\text { Native Hawaiian or other Pacific Islander } \\
\text { Black or African American } \\
\text { White } \\
\end{array}$ & $\begin{array}{l}\text { N.S. } \\
\text { N.S. } \\
.1 \% \\
4.7 \% \\
93.6 \% \\
\end{array}$ & $\begin{array}{r}.071 \\
.945 \\
9.100 \\
64.483 \\
65.982 \\
\end{array}$ & $\begin{array}{l}1 \\
1 \\
1 \\
1 \\
1\end{array}$ & $\begin{array}{l}.790 \\
.331 \\
.003^{*} \\
.000^{*} \\
.000^{*}\end{array}$ \\
\hline $\begin{array}{l}\text { Ethnicity } \\
\text { Hispanic or Latino } \\
\text { White Non-Hispanic or Latino } \\
\text { Black Non-Hispanic or Latino } \\
\text { Other Non-Hispanic or Latino } \\
\end{array}$ & $\begin{array}{c}3.2 \% \\
88.5 \% \\
4.7 \% \\
1.5 \% \\
\end{array}$ & 79.279 & 4 & $.000^{*}$ \\
\hline $\begin{array}{l}\text { Marital Status } \\
\text { Married } \\
\text { Widowed } \\
\text { Divorced } \\
\text { Separated } \\
\text { Never Married } \\
\text { Living with a Partner }\end{array}$ & $\begin{array}{c}41.9 \% \\
40.2 \% \\
6.7 \% \\
.7 \% \\
6.1 \% \\
.7 \% \\
\end{array}$ & 136.143 & 6 & $.000^{*}$ \\
\hline Veteran & $10.9 \%$ & 15.719 & 3 & $.001 *$ \\
\hline
\end{tabular}


Table 32

Patient Advanced Directive Status, Caregiver Status, \& Household Membership

\begin{tabular}{|c|c|c|c|c|}
\hline & $\%$ of Those With Advanced Directives & $\chi^{2}$ & $d f$ & $p$ \\
\hline Caregiver & $89.5 \%$ & 33.498 & 2 & $.000 *$ \\
\hline $\begin{array}{l}\text { Identification of the Caregiver } \\
\text { Spouse } \\
\text { Child } \\
\text { Parent } \\
\text { Other family Member } \\
\text { Non-Family Member } \\
\end{array}$ & $\begin{array}{c}32.2 \% \\
30.3 \% \\
1.4 \% \\
8.5 \% \\
17 \% \\
\end{array}$ & 139.387 & 6 & $.000^{*}$ \\
\hline $\begin{array}{l}\text { Household Membership } \\
\text { Alone } \\
\text { Family }\end{array}$ & $\begin{array}{l}13.1 \% \\
51.5 \%\end{array}$ & 183.118 & 5 & $.000 *$ \\
\hline $\begin{array}{l}\text { Spouse or Significant Other } \\
\text { Parent } \\
\text { Child } \\
\text { Other Family Members } \\
\text { Non-Family Members } \\
\text { Family and Non-Family }\end{array}$ & $\begin{array}{c}31 \% \\
1 \% \\
17 \% \\
5 \%\end{array}$ & $\begin{array}{l}195.992 \\
236.326 \\
180.555 \\
175.476\end{array}$ & $\begin{array}{l}3 \\
3 \\
3 \\
3\end{array}$ & $\begin{array}{l}.000^{*} \\
.000^{*} \\
.000^{*} \\
.000^{*}\end{array}$ \\
\hline
\end{tabular}

$* p$ values $\leq .05$ 
Table 33

Patient Advanced Directive Status \& Patient Location at the Beginning as Well as End of Care

\begin{tabular}{|c|c|c|c|c|}
\hline & $\%$ of Those With Advanced Directives & $\chi^{2}$ & $d f$ & $p$ \\
\hline $\begin{array}{l}\text { Location at the Beginning of Care } \\
\text { Private Home } \\
\text { Nursing Home/Skilled Nursing Facility } \\
\text { Hospital } \\
\text { Residential Care Place } \\
\text { Agency Inpatient/Residential Facility } \\
\text { Other }\end{array}$ & $\begin{array}{c}49.4 \% \\
17.3 \% \\
6.8 \% \\
3.6 \% \\
5.8 \% \\
.7 \%\end{array}$ & 801.055 & 7 & $.000^{*}$ \\
\hline $\begin{array}{l}\text { Location at the End of Care } \\
\text { Private Home } \\
\text { Nursing Home/Skilled Nursing Facility } \\
\text { Hospital } \\
\text { Residential Care Place } \\
\text { Agency Inpatient/Residential Facility } \\
\text { Other }\end{array}$ & $\begin{array}{c}43.4 \% \\
19.9 \% \\
6.9 \% \\
3.8 \% \\
8.6 \% \\
1 \%\end{array}$ & 802.955 & 7 & $.000^{*}$ \\
\hline
\end{tabular}

$* p$ values $\leq .05$ 


\section{Table 34}

Patient Utilization of Psychosocial Services Based on Advanced Directive Status

\begin{tabular}{|c|c|c|c|c|}
\hline Psychosocial Service & $\begin{array}{l}\text { \% of Patients Had Advanced Directives } \\
\text { \& Used the Service }\end{array}$ & $\chi^{2}$ & df & $p$ \\
\hline Medical Social Services & $70 \%$ & 479.139 & 1 & $.000 *$ \\
\hline Medical Social Service Visit Frequency & Average 3.25 visits & 568.353 & 51 & $.000 *$ \\
\hline Resource Referral Services & N.S. & .481 & 1 & .488 \\
\hline Mental Health Services & N.S. & 1.265 & 1 & .261 \\
\hline Respite Care Services & $7.4 \%$ & 15.879 & 1 & $.000 *$ \\
\hline Ethical Issues Counseling & $6.3 \%$ & 12.180 & 1 & $.000 *$ \\
\hline Interpreter Services & N.S. & 1.132 & 1 & .287 \\
\hline Homemaker Services & N.S. & .319 & 1 & .572 \\
\hline Transportation Services & N.S. & 3.662 & 1 & .056 \\
\hline Meals on Wheels Services & N.S. & 1.339 & 1 & .247 \\
\hline Complementary and Alternative Medicine Services & $4.4 \%$ & 26.911 & 1 & $.000^{*}$ \\
\hline Pastoral Care Services & $54.9 \%$ & 357.263 & 1 & $.000 *$ \\
\hline Volunteer Services & $25.8 \%$ & 114.858 & 1 & $.000 *$ \\
\hline
\end{tabular}

$* p$ values $\leq .05$ 
Table 35

Caregiver Utilization of Psychosocial Services Based on Patient Advanced Directive Status

\begin{tabular}{|c|c|c|c|c|}
\hline Psychosocial Service & $\begin{array}{c}\text { \% of Patients With Advanced } \\
\text { Directives Who Had A Caregiver That } \\
\text { Used the Service }\end{array}$ & $\chi^{2}$ & $\mathrm{df}$ & $p$ \\
\hline Bereavement Services & $71 \%$ & 623.591 & 3 & $.000 *$ \\
\hline Caregiver Health and Wellness Services & $26.7 \%$ & 63.191 & 3 & $.000 *$ \\
\hline Spiritual Care Services & $56 \%$ & 334.569 & 3 & $.000 *$ \\
\hline Dealing with Difficult Behaviors Services & $17 \%$ & 30.261 & 3 & $.000 *$ \\
\hline Safety Training Services & N.S. & 2.266 & 3 & .519 \\
\hline Suspected Abuse or Neglect Services & $5 \%$ & 11.680 & 3 & $.009 *$ \\
\hline Resource Referral Information Services & $22 \%$ & 14.891 & 3 & $.002 *$ \\
\hline
\end{tabular}

$* p$ values $\leq .05$ 
Interpreter services. Overall, .3\% of patients utilized interpreter services. Patient diagnosis, cognitive status, and total ADL needs were not significantly related to use of interpreter services. Patient level of care and length of service were also insignificantly related to use of this service. Medicare patients represented $62.5 \%$ of those who used this service. Patient age and gender were not significantly related to interpreter service utilization. Only Asian racial identity was significantly related to use of this service. Asian represented $12.5 \%$ of patients that used this service. Hispanic or Latino patients represented the highest amount of patients that used interpreter services. Married patients accounted for $50 \%$ of patients who used this service. Patient veteran status was not significantly related to use of this service.

Patient caregiver status and identification of the caregiver were not significant. Patients who lived with a family member accounted for most of the patients who used this service (75\%). Identification of which family member the patient lived with was not significant. Patient location at the beginning and end of care was not significantly related to use of interpreter services. (see Tables36- 40) 
Patient Utilization of Interpreter Services Based on Primary Diagnosis, Cognitive Status, \& Total ADL Needs

\begin{tabular}{|c|c|c|c|c|}
\hline & $\%$ of Those Who Used the Service & $\chi^{2}$ & $\mathrm{df}$ & $p$ \\
\hline $\begin{array}{l}\text { Diagnosis } \\
\text { Lung, Bronchial, or Tracheal Cancer } \\
\text { Heart Failure } \\
\text { Unspecified Chronic Airway Obstruction } \\
\text { Unknown Cause of Morbidity } \\
\end{array}$ & N.S. & 74.910 & 229 & 1.000 \\
\hline $\begin{array}{l}\text { Cognitive Status } \\
\text { No Cognitive Impairment } \\
\text { Occasional Reminders } \\
\text { Some Assistance } \\
\text { Great Deal of Assistance } \\
\text { Severe Cognitive Impairment }\end{array}$ & N.S. & 8.347 & 6 & .214 \\
\hline $\begin{array}{l}\text { Patient Total ADL Needs } \\
\text { None } \\
\text { One } \\
\text { Two } \\
\text { Three } \\
\text { Four } \\
\text { Five }\end{array}$ & N.S. & 6.239 & 7 & .512 \\
\hline
\end{tabular}

$* p$ values $\leq .05$ 
Patient Utilization of Interpreter Services Based on Level of Care, Length of Service, \& Payer Source

\begin{tabular}{|c|c|c|c|c|}
\hline & $\%$ of Those Who Used the Service & $\chi^{2}$ & df & $p$ \\
\hline $\begin{array}{l}\text { Level of Care } \\
\text { Routine Homecare } \\
\text { Continuous Home Care } \\
\text { General Inpatient } \\
\text { Inpatient Respite }\end{array}$ & N.S. & 1.389 & 6 & .967 \\
\hline Length of Service & N.S. & 210.528 & 293 & 1.000 \\
\hline $\begin{array}{l}\text { Payer Source } \\
\text { Medicare } \\
\text { Medicaid } \\
\text { Tricare } \\
\text { Department of Veteran Affairs } \\
\text { Worker's Compensation } \\
\text { Other Government Funding } \\
\text { Private Insurance } \\
\text { Long-Term Care Insurance } \\
\text { Self-Pay } \\
\text { No Charge for Care } \\
\text { Undetermined Payer Source } \\
\text { Other }\end{array}$ & $\begin{array}{c}62.5 \% \\
0 \% \\
0 \% \\
12.5 \% \\
0 \% \\
0 \% \\
0 \% \\
0 \% \\
12.5 \% \\
0 \% \\
0 \% \\
12.5 \%\end{array}$ & 23.746 & 14 & $.049 *$ \\
\hline
\end{tabular}

$* p$ values $\leq .05$ 
Table 38

Patient Utilization of Interpreter Services, Age at Discharge, Gender, Race, Ethnicity, Marital Status, \& Veteran Status

\begin{tabular}{|c|c|c|c|c|}
\hline & $\%$ of Those Who Used the Service & $\chi^{2}$ & df & $p$ \\
\hline Patient Age at Discharge & N.S. & 46.576 & 75 & .996 \\
\hline $\begin{array}{l}\text { Gender } \\
\text { Male } \\
\text { Female } \\
\end{array}$ & N.S. & 3.320 & 1 & .068 \\
\hline $\begin{array}{l}\text { Race } \\
\text { American Indian or Alaskan Native } \\
\text { Asian } \\
\text { Native Hawaiian or other Pacific Islander } \\
\text { Black or African American } \\
\text { White }\end{array}$ & $\begin{array}{l}\text { N.S. } \\
12.5 \% \\
\text { N.S. } \\
\text { N.S. } \\
\text { N.S. }\end{array}$ & $\begin{array}{c}.057 \\
10.800 \\
.023 \\
.674 \\
.068 \\
\end{array}$ & $\begin{array}{l}1 \\
1 \\
1 \\
1 \\
1\end{array}$ & $\begin{array}{l}.811 \\
.001 * \\
.879 \\
.412 \\
.795 \\
\end{array}$ \\
\hline $\begin{array}{l}\text { Ethnicity } \\
\text { Hispanic or Latino } \\
\text { White Non-Hispanic or Latino } \\
\text { Black Non-Hispanic or Latino } \\
\text { Other Non-Hispanic or Latino } \\
\end{array}$ & $\begin{array}{c}75 \% \\
0 \% \\
0 \% \\
12.5 \% \\
\end{array}$ & 123.184 & 4 & $.000^{*}$ \\
\hline $\begin{array}{l}\text { Marital Status } \\
\text { Married } \\
\text { Widowed } \\
\text { Divorced } \\
\text { Separated } \\
\text { Never Married } \\
\text { Living with a Partner } \\
\end{array}$ & $\begin{array}{c}50 \% \\
25 \% \\
12.5 \% \\
12.5 \% \\
0 \% \\
0 \% \\
\end{array}$ & 15.974 & 6 & $.014^{*}$ \\
\hline Veteran & N.S. & 5.322 & 3 & 1.50 \\
\hline
\end{tabular}

$* p$ values $\leq .05$ 
Table 39

Patient Utilization of Interpreter, Caregiver Status, \& Household Membership

\begin{tabular}{|c|c|c|c|c|}
\hline & $\%$ of Those Who Used the Service & $\chi^{2}$ & $d f$ & $p$ \\
\hline Caregiver & N.S. & .057 & 2 & .972 \\
\hline $\begin{array}{l}\text { Identification of the Caregiver } \\
\text { Spouse } \\
\text { Child } \\
\text { Parent } \\
\text { Other family Member } \\
\text { Non-Family Member } \\
\end{array}$ & N.S. & 5.634 & 6 & .465 \\
\hline $\begin{array}{l}\text { Household Membership } \\
\text { Alone } \\
\text { Family }\end{array}$ & $\begin{array}{c}0 \% \\
75 \%\end{array}$ & 25.929 & 5 & $.000 *$ \\
\hline $\begin{array}{l}\text { Spouse or Significant Other } \\
\text { Parent } \\
\text { Child } \\
\text { Other Family Members }\end{array}$ & $\begin{array}{l}\text { N.S. } \\
\text { N.S. } \\
\text { N.S. } \\
\text { N.S. }\end{array}$ & $\begin{array}{l}1.388 \\
.931 \\
2.907 \\
1.215\end{array}$ & $\begin{array}{l}3 \\
3 \\
3 \\
3\end{array}$ & $\begin{array}{l}.708 \\
.818 \\
.406 \\
.749\end{array}$ \\
\hline $\begin{array}{l}\text { Non-Family Members } \\
\text { Family and Non-Family }\end{array}$ & $\begin{array}{c}0 \% \\
12.5 \%\end{array}$ & & & \\
\hline
\end{tabular}


Patient Utilization of Interpreter \& Patient Location at the Beginning as Well as End of Care

\begin{tabular}{|c|c|c|c|c|}
\hline & $\%$ of Those Who Used the Service & $\chi^{2}$ & $d f$ & $p$ \\
\hline $\begin{array}{l}\text { Location at the Beginning of Care } \\
\text { Private Home } \\
\text { Nursing Home/Skilled Nursing Facility } \\
\text { Hospital } \\
\text { Residential Care Place } \\
\text { Agency Inpatient/Residential Facility } \\
\text { Other }\end{array}$ & N.S. & 1.249 & 7 & .990 \\
\hline $\begin{array}{l}\text { Location at the End of Care } \\
\text { Private Home } \\
\text { Nursing Home/Skilled Nursing Facility } \\
\text { Hospital } \\
\text { Residential Care Place } \\
\text { Agency Inpatient/Residential Facility } \\
\text { Other }\end{array}$ & N.S. & 1.825 & 7 & .969 \\
\hline
\end{tabular}

$* p$ values $\leq .05$ 
Homemaker services. Overall, $18.1 \%$ of patients utilized homemaker services. Patient diagnosis was not significant.ly related to use of this service. Those with no cognitive impairment utilized homemaker services the most (34.5\%). Patients with four total ADL needs represented the most patients that used this service (30.1\%). Hospice patients under routine home care represented $56.8 \%$ of patients that used homemaker services. Patients who used this service had an average length of 90service days. Medicare patients represented $66 \%$ of those who used this service. Patient age and gender were not significantly related to homemaker service use. Black or African American and White racial identity were the only once significantly associated with use of homemaker services. White patients used this service the most (84.9\%). Furthermore, White nonHispanics represented the highest amount of patients that used this service (80.1\%). Patient marital and veteran statuses were not significantly related to use of this service.

Patient caregiver status was not significant. Those with their child as the caregiver represented 33.3\% of patients who used this service. Patients who lived with a family member accounted for most of the patients who used this service (59.6\%). More specifically, those who had household membership with their spouse represented $29 \%$ of those who lived with a family member. Patients that lived in a private home at the beginning of care accounted for $50.5 \%$. At the end of care, patients that lived in a private home also represented the most of the patients that used homemaker services (42.7\%). (see Tables 41- 45) 
Table 41

Patient Utilization of Homemaker Services Based on Primary Diagnosis, Cognitive Status, \& Total ADL Needs

\begin{tabular}{|c|c|c|c|c|}
\hline & $\%$ of Those Who Used the Service & $\chi^{2}$ & $\mathrm{df}$ & $p$ \\
\hline Diagnosis & N.S. & 235.055 & 229 & .378 \\
\hline $\begin{array}{l}\text { Cognitive Status } \\
\text { No Cognitive Impairment } \\
\text { Occasional Reminders } \\
\text { Some Assistance } \\
\text { Great Deal of Assistance } \\
\text { Severe Cognitive Impairment }\end{array}$ & $\begin{array}{c}34.5 \% \\
19.6 \% \\
16.7 \% \\
16.2 \% \\
9.4 \%\end{array}$ & 19.422 & 6 & $.004 *$ \\
\hline $\begin{array}{l}\text { Patient Total ADL Needs } \\
\text { None } \\
\text { One } \\
\text { Two } \\
\text { Three } \\
\text { Four } \\
\text { Five }\end{array}$ & $\begin{array}{c}9.1 \% \\
3.7 \% \\
11.4 \% \\
14.6 \% \\
30.1 \% \\
22.1 \%\end{array}$ & 32.594 & 7 & $.000 *$ \\
\hline
\end{tabular}

$* p$ values $\leq .05$ 
Table 42

Patient Utilization of Homemaker Services Based on Level of Care, Length of Service, \& Payer Source

\begin{tabular}{|c|c|c|c|c|}
\hline & $\%$ of Those Who Used the Service & $\chi^{2}$ & df & $p$ \\
\hline $\begin{array}{l}\text { Level of Care } \\
\text { Routine Homecare } \\
\text { Continuous Home Care } \\
\text { General Inpatient } \\
\text { Inpatient Respite } \\
\end{array}$ & $\begin{array}{c}56.8 \% \\
4.6 \% \\
6.4 \% \\
.7 \% \\
\end{array}$ & 25.268 & 6 & $.000 *$ \\
\hline Length of Service & Average 90 days & 432.639 & 293 & $.000 *$ \\
\hline $\begin{array}{l}\text { Payer Source } \\
\text { Medicare } \\
\text { Medicaid } \\
\text { Tricare } \\
\text { Department of Veteran Affairs } \\
\text { Worker's Compensation } \\
\text { Other Government Funding } \\
\text { Private Insurance } \\
\text { Long-Term Care Insurance } \\
\text { Self-Pay } \\
\text { No Charge for Care } \\
\text { Undetermined Payer Source } \\
\text { Other }\end{array}$ & $\begin{array}{c}66 \% \\
19.4 \% \\
0 \% \\
.2 \% \\
.5 \% \\
2.5 \% \\
4.8 \% \\
0 \% \\
3.9 \% \\
.9 \% \\
0 \% \\
.9 \%\end{array}$ & 80.885 & 14 & $.000^{*}$ \\
\hline
\end{tabular}

$* p$ values $\leq .05$ 
Table 43

Patient Utilization of Homemaker Services, Age at Discharge, Gender, Race, Ethnicity, Marital Status, \& Veteran Status

\begin{tabular}{|c|c|c|c|c|}
\hline & $\%$ of Those Who Used the Service & $\chi^{2}$ & $\mathrm{df}$ & $p$ \\
\hline Patient Age at Discharge & N.S. & 65.524 & 75 & .775 \\
\hline $\begin{array}{l}\text { Gender } \\
\text { Male } \\
\text { Female }\end{array}$ & N.S. & .918 & 1 & .338 \\
\hline $\begin{array}{l}\text { Race } \\
\text { American Indian or Alaskan Native } \\
\text { Asian } \\
\text { Native Hawaiian or other Pacific Islander } \\
\text { Black or African American } \\
\text { White }\end{array}$ & $\begin{array}{l}\text { N.S. } \\
\text { N.S. } \\
\text { N.S. } \\
13.7 \% \\
84.9 \% \\
\end{array}$ & $\begin{array}{c}.003 \\
.519 \\
1.555 \\
26.563 \\
17.021 \\
\end{array}$ & $\begin{array}{l}1 \\
1 \\
1 \\
1 \\
1\end{array}$ & $\begin{array}{l}.958 \\
.471 \\
.212 \\
.000 * \\
.000 *\end{array}$ \\
\hline $\begin{array}{l}\text { Ethnicity } \\
\text { Hispanic or Latino } \\
\text { White Non-Hispanic or Latino } \\
\text { Black Non-Hispanic or Latino } \\
\text { Other Non-Hispanic or Latino } \\
\end{array}$ & $\begin{array}{c}3.2 \% \\
80.1 \% \\
13.7 \% \\
1.4 \% \\
\end{array}$ & 31.520 & 4 & $.000 *$ \\
\hline $\begin{array}{l}\text { Marital Status } \\
\text { Married } \\
\text { Widowed } \\
\text { Divorced } \\
\text { Separated } \\
\text { Never Married } \\
\text { Living with a Partner } \\
\end{array}$ & N.S. & 10.957 & 6 & .090 \\
\hline Veteran & N.S. & 5.291 & 3 & .152 \\
\hline
\end{tabular}


Table 44

Patient Utilization of Homemaker Services, Caregiver Status, \& Household Membership

\begin{tabular}{|c|c|c|c|c|}
\hline & $\%$ of Those Who Used the Service & $\chi^{2}$ & $d f$ & $p$ \\
\hline Caregiver & N.S. & 5.382 & 2 & .068 \\
\hline $\begin{array}{l}\text { Identification of the Caregiver } \\
\text { Spouse } \\
\text { Child } \\
\text { Parent } \\
\text { Other family Member } \\
\text { Non-Family Member }\end{array}$ & $\begin{array}{c}29.5 \% \\
33.3 \% \\
3.9 \% \\
9.6 \% \\
8.2 \%\end{array}$ & 23.148 & 6 & $.001 *$ \\
\hline $\begin{array}{l}\text { Household Membership } \\
\text { Alone } \\
\text { Family }\end{array}$ & $\begin{array}{l}21.5 \% \\
59.6 \%\end{array}$ & 29.156 & 5 & $.000^{*}$ \\
\hline $\begin{array}{l}\text { Spouse or Significant Other } \\
\text { Parent } \\
\text { Child } \\
\text { Other Family Members }\end{array}$ & $\begin{array}{c}29 \% \\
3 \% \\
23 \% \\
6 \%\end{array}$ & $\begin{array}{l}26.091 \\
22.031 \\
33.343 \\
21.693\end{array}$ & $\begin{array}{l}3 \\
3 \\
3 \\
3\end{array}$ & $\begin{array}{l}.000^{*} \\
.000^{*} \\
.000^{*} \\
.000^{*}\end{array}$ \\
\hline $\begin{array}{l}\text { Non-Family Members } \\
\text { Family and Non-Family }\end{array}$ & $\begin{array}{c}4.6 \% \\
0 \%\end{array}$ & & & \\
\hline
\end{tabular}

$* p$ values $\leq .05$ 
Table 45

Patient Utilization of Homemaker Services \& Patient Location at the Beginning as Well as End of Care

\begin{tabular}{|c|c|c|c|c|}
\hline & $\%$ of Those Who Used the Service & $\chi^{2}$ & $d f$ & $p$ \\
\hline $\begin{array}{l}\text { Location at the Beginning of Care } \\
\text { Private Home } \\
\text { Nursing Home/Skilled Nursing Facility } \\
\text { Hospital } \\
\text { Residential Care Place } \\
\text { Agency Inpatient/Residential Facility } \\
\text { Other }\end{array}$ & $\begin{array}{c}50.5 \% \\
8 \% \\
2.3 \% \\
2.6 \% \\
5.3 \% \\
.2 \%\end{array}$ & 39.025 & 7 & $.000 *$ \\
\hline $\begin{array}{l}\text { Location at the End of Care } \\
\text { Private Home } \\
\text { Nursing Home/Skilled Nursing Facility } \\
\text { Hospital } \\
\text { Residential Care Place } \\
\text { Agency Inpatient/Residential Facility } \\
\text { Other }\end{array}$ & $\begin{array}{c}42.7 \% \\
10.7 \% \\
4.6 \% \\
3 \% \\
7.3 \% \\
.5 \%\end{array}$ & 20.688 & 7 & $.004^{*}$ \\
\hline
\end{tabular}

$* p$ values $\leq .05$ 
Transportation services. Overall, $2.2 \%$ of patients utilized transportation services. The majority of the patients who used this service had cancer, specifically either the lung, bronchial, or tracheal form of the disease (13\%). Patient cognitive status, total ADL, and level of care needs were not significantly related to use of this service. Patients who used this service had an average length of 110 service days. Medicare patients represented $51.9 \%$ of those who used this service. Patient age, gender, race, and ethnicity were not significantly related to transportation service use. Married patients accounted for $22.2 \%$ of patients who used this service. Patient veteran status was not significant. Patient caregiver status and identification of the caregiver were not significantly related to use of transportation services. Patients who lived with a family member as well as those who lived alone both accounted for most of the patients who used this service (70\% combined). Identification of which family member the patient lived with was not significant. Location at the beginning as well as location at the end of care was not significantly related to use of transportation services.(see Table 46- 50) 
Patient Utilization of Transportation Services Based on Primary Diagnosis, Cognitive Status, \& Total ADL Needs

\begin{tabular}{|c|c|c|c|c|}
\hline & $\%$ of Those Who Used the Service & $\chi^{2}$ & $\mathrm{df}$ & $p$ \\
\hline $\begin{array}{l}\text { Diagnosis } \\
\text { Lung, Bronchial, or Tracheal Cancer } \\
\text { Heart Failure } \\
\text { Other Forms of Chronic Ischemic Heart Disease }\end{array}$ & $\begin{array}{l}13 \% \\
7.4 \% \\
5.6 \% \\
\end{array}$ & 276.766 & 229 & $.017 *$ \\
\hline $\begin{array}{l}\text { Cognitive Status } \\
\text { No Cognitive Impairment } \\
\text { Occasional Reminders } \\
\text { Some Assistance } \\
\text { Great Deal of Assistance } \\
\text { Severe Cognitive Impairment }\end{array}$ & N.S. & 4.113 & 6 & .661 \\
\hline $\begin{array}{l}\text { Patient Total ADL Needs } \\
\text { None } \\
\text { One } \\
\text { Two } \\
\text { Three } \\
\text { Four } \\
\text { Five }\end{array}$ & N.S. & 7.100 & 7 & .419 \\
\hline
\end{tabular}

$* p$ values $\leq .05$ 
Table 47

Patient Utilization of Transportation Services Based on Level of Care, Length of Service, \& Payer Source

\begin{tabular}{|c|c|c|c|c|}
\hline & $\%$ of Those Who Used the Service & $\chi^{2}$ & df & $p$ \\
\hline $\begin{array}{l}\text { Level of Care } \\
\text { Routine Homecare } \\
\text { Continuous Home Care } \\
\text { General Inpatient } \\
\text { Inpatient Respite } \\
\end{array}$ & N.S. & 5.940 & 6 & .430 \\
\hline Length of Service & Average 110 days & 480.352 & 293 & $.000 *$ \\
\hline $\begin{array}{l}\text { Payer Source } \\
\text { Medicare } \\
\text { Medicaid } \\
\text { Tricare } \\
\text { Department of Veteran Affairs } \\
\text { Worker's Compensation } \\
\text { Other Government Funding } \\
\text { Private Insurance } \\
\text { Long-Term Care Insurance } \\
\text { Self-Pay } \\
\text { No Charge for Care } \\
\text { Undetermined Payer Source } \\
\text { Other }\end{array}$ & $\begin{array}{c}51.9 \% \\
9.3 \% \\
0 \% \\
0 \% \\
1.9 \% \\
1.9 \% \\
9.3 \% \\
0 \% \\
14.8 \% \\
1.9 \% \\
0 \% \\
0 \%\end{array}$ & 61.116 & 14 & $.000^{*}$ \\
\hline
\end{tabular}

$* p$ values $\leq .05$ 
Table 48

Patient Utilization of Transportation Services, Age at Discharge, Gender, Race, Ethnicity, Marital Status, \& Veteran Status

\begin{tabular}{|c|c|c|c|c|}
\hline & $\%$ of Those Who Used the Service & $\chi^{2}$ & df & $p$ \\
\hline Patient Age at Discharge & N.S. & 65.399 & 75 & .779 \\
\hline $\begin{array}{l}\text { Gender } \\
\text { Male } \\
\text { Female } \\
\end{array}$ & N.S. & 1.427 & 1 & .232 \\
\hline $\begin{array}{l}\text { Race } \\
\text { American Indian or Alaskan Native } \\
\text { Asian } \\
\text { Native Hawaiian or other Pacific Islander } \\
\text { Black or African American } \\
\text { White } \\
\end{array}$ & $\begin{array}{l}\text { N.S. } \\
\text { N.S. } \\
\text { N.S. } \\
\text { N.S. } \\
\text { N.S. }\end{array}$ & $\begin{array}{c}1.041 \\
.413 \\
.161 \\
1.262 \\
.350 \\
\end{array}$ & $\begin{array}{l}1 \\
1 \\
1 \\
1 \\
1\end{array}$ & $\begin{array}{l}.308 \\
.520 \\
.689 \\
.261 \\
.554 \\
\end{array}$ \\
\hline $\begin{array}{l}\text { Ethnicity } \\
\text { Hispanic or Latino } \\
\text { White Non-Hispanic or Latino } \\
\text { Black Non-Hispanic or Latino } \\
\text { Other Non-Hispanic or Latino } \\
\end{array}$ & N.S. & 3.716 & 4 & .446 \\
\hline $\begin{array}{l}\text { Marital Status } \\
\text { Married } \\
\text { Widowed } \\
\text { Divorced } \\
\text { Separated } \\
\text { Never Married } \\
\text { Living with a Partner } \\
\end{array}$ & $\begin{array}{c}22.2 \% \\
41.6 \% \\
16.7 \% \\
0 \% \\
5.6 \% \\
0 \% \\
\end{array}$ & 18.602 & 6 & $.005^{*}$ \\
\hline Veteran & N.S. & 4.261 & 3 & .235 \\
\hline
\end{tabular}

$* p$ values $\leq .05$ 
Table 49

Patient Utilization of Transportation Services, Caregiver Status, \& Household Membership

\begin{tabular}{|c|c|c|c|c|}
\hline & $\%$ of Those Who Used the Service & $\chi^{2}$ & $d f$ & $p$ \\
\hline Caregiver & N.S. & 1.331 & 2 & .514 \\
\hline $\begin{array}{l}\text { Identification of the Caregiver } \\
\text { Spouse } \\
\text { Child } \\
\text { Parent } \\
\text { Other family Member } \\
\text { Non-Family Member } \\
\end{array}$ & N.S. & 10.966 & 6 & .089 \\
\hline $\begin{array}{l}\text { Household Membership } \\
\text { Alone } \\
\text { Family }\end{array}$ & $\begin{array}{l}35.2 \% \\
35.2 \%\end{array}$ & 18.061 & 5 & $.003 *$ \\
\hline $\begin{array}{l}\text { Spouse or Significant Other } \\
\text { Parent } \\
\text { Child } \\
\text { Other Family Members }\end{array}$ & $\begin{array}{l}\text { N.S. } \\
\text { N.S. } \\
\text { N.S. } \\
\text { N.S. }\end{array}$ & $\begin{array}{c}5.719 \\
.383 \\
.763 \\
2.640\end{array}$ & $\begin{array}{l}3 \\
3 \\
3 \\
3\end{array}$ & $\begin{array}{l}.126 \\
.944 \\
.858 \\
.450\end{array}$ \\
\hline $\begin{array}{l}\text { Non-Family Members } \\
\text { Family and Non-Family }\end{array}$ & $\begin{array}{c}9.3 \% \\
0 \%\end{array}$ & & & \\
\hline
\end{tabular}

$* p$ values $\leq .05$ 
Table 50

Patient Utilization of Transportation Services \& Patient Location at the Beginning as Well as End of Care

\begin{tabular}{|c|c|c|c|c|}
\hline & $\%$ of Those Who Used the Service & $\chi^{2}$ & $d f$ & $p$ \\
\hline $\begin{array}{l}\text { Location at the Beginning of Care } \\
\text { Private Home } \\
\text { Nursing Home/Skilled Nursing Facility } \\
\text { Hospital } \\
\text { Residential Care Place } \\
\text { Agency Inpatient/Residential Facility } \\
\text { Other }\end{array}$ & N.S. & 6.644 & 7 & .467 \\
\hline $\begin{array}{l}\text { Location at the End of Care } \\
\text { Private Home } \\
\text { Nursing Home/Skilled Nursing Facility } \\
\text { Hospital } \\
\text { Residential Care Place } \\
\text { Agency Inpatient/Residential Facility } \\
\text { Other }\end{array}$ & N.S. & 8.406 & 7 & .298 \\
\hline
\end{tabular}

$* p$ values $\leq .05$ 
Meals on Wheels services. Overall, 1.6\% of patients utilized Meals on Wheels services. Patient diagnosis, cognitive status, total ADL needs, and level of care were not significantly related to use of this service. Patients who used Meals on Wheels services had an average length of 175 service days. Patient payer source, age, gender, race, ethnicity, marriage status, and veteran status were not significantly related to use of Meals on Wheels services.

Patient caregiver statuses as well as the identification of the caregiver were not significantly related to use of this service. Patients who lived with a family member accounted for most of the patients who used this service (46.2\%). Household memberships with a spouse or other family member were the only ones to yield significant results. Those who had household membership with their spouse represented $20 \%$ of those who lived with a family member. Patient location at the beginning and end of care was not significant. (see Tables 51- 55) 
Table 51

Patient Utilization of Meals on Wheels Services Based on Primary Diagnosis, Cognitive Status, \& Total ADL Needs

\begin{tabular}{|c|c|c|c|c|}
\hline & $\%$ of Those Who Used the Service & $\chi^{2}$ & $\mathrm{df}$ & $p$ \\
\hline $\begin{array}{l}\text { Diagnosis } \\
\text { Lung, Bronchial, or Tracheal Cancer } \\
\text { Heart Failure } \\
\text { Unspecified Chronic Airway Obstruction } \\
\text { Unknown Cause of Morbidity }\end{array}$ & N.S. & 77.446 & 229 & 1.000 \\
\hline $\begin{array}{l}\text { Cognitive Status } \\
\text { No Cognitive Impairment } \\
\text { Occasional Reminders } \\
\text { Some Assistance } \\
\text { Great Deal of Assistance } \\
\text { Severe Cognitive Impairment }\end{array}$ & N.S. & 8.345 & 6 & .214 \\
\hline $\begin{array}{l}\text { Patient Total ADL Needs } \\
\text { None } \\
\text { One } \\
\text { Two } \\
\text { Three } \\
\text { Four } \\
\text { Five }\end{array}$ & N.S. & 8.345 & 6 & .214 \\
\hline
\end{tabular}

$* p$ values $\leq .05$ 
Patient Utilization of Meals on Wheels Services Based on Level of Care, Length of Service, \& Payer Source

\begin{tabular}{|c|c|c|c|c|}
\hline & $\%$ of Those Who Used the Service & $\chi^{2}$ & df & $p$ \\
\hline $\begin{array}{l}\text { Level of Care } \\
\text { Routine Homecare } \\
\text { Continuous Home Care } \\
\text { General Inpatient } \\
\text { Inpatient Respite }\end{array}$ & N.S. & 6.226 & 6 & .398 \\
\hline Length of Service & Average 175 days & 905.332 & 293 & $.000^{*}$ \\
\hline $\begin{array}{l}\text { Payer Source } \\
\text { Medicare } \\
\text { Medicaid } \\
\text { Tricare } \\
\text { Department of Veteran Affairs } \\
\text { Worker's Compensation } \\
\text { Other Government Funding } \\
\text { Private Insurance } \\
\text { Long-Term Care Insurance } \\
\text { Self-Pay } \\
\text { No Charge for Care } \\
\text { Undetermined Payer Source } \\
\text { Other }\end{array}$ & N.S. & 3.011 & 14 & .999 \\
\hline
\end{tabular}

$* p$ values $\leq .05$ 
Table 53

Patient Utilization of Meals on Wheels Service, Age at Discharge, Gender, Race, Ethnicity, Marital Status, \& Veteran Status

\begin{tabular}{|c|c|c|c|c|}
\hline & $\%$ of Those Who Used the Service & $\chi^{2}$ & $\mathrm{df}$ & $p$ \\
\hline Patient Age at Discharge & N.S. & 47.634 & 75 & .994 \\
\hline $\begin{array}{l}\text { Gender } \\
\text { Male } \\
\text { Female }\end{array}$ & N.S. & 849 & 1 & .357 \\
\hline $\begin{array}{l}\text { Race } \\
\text { American Indian or Alaskan Native } \\
\text { Asian } \\
\text { Native Hawaiian or other Pacific Islander } \\
\text { Black or African American } \\
\text { White }\end{array}$ & $\begin{array}{l}\text { N.S. } \\
\text { N.S. } \\
\text { N.S. } \\
\text { N.S. } \\
\text { N.S. }\end{array}$ & $\begin{array}{l}.281 \\
.398 \\
.115 \\
.350 \\
.011\end{array}$ & $\begin{array}{l}1 \\
1 \\
1 \\
1 \\
1\end{array}$ & $\begin{array}{l}.596 \\
.528 \\
.734 \\
.554 \\
.918\end{array}$ \\
\hline $\begin{array}{l}\text { Ethnicity } \\
\text { Hispanic or Latino } \\
\text { White Non-Hispanic or Latino } \\
\text { Black Non-Hispanic or Latino } \\
\text { Other Non-Hispanic or Latino }\end{array}$ & N.S. & 3.836 & 4 & .429 \\
\hline $\begin{array}{l}\text { Marital Status } \\
\text { Married } \\
\text { Widowed } \\
\text { Divorced } \\
\text { Separated } \\
\text { Never Married } \\
\text { Living with a Partner }\end{array}$ & N.S. & 8.428 & 6 & .208 \\
\hline Veteran & N.S. & 3.107 & 3 & .375 \\
\hline
\end{tabular}

$* p$ values $\leq .05$ 
Table 54

Patient Utilization of Meals on Wheels Services, Caregiver Status, \& Household Membership

\begin{tabular}{|c|c|c|c|c|}
\hline & $\%$ of Those Who Used the Service & $\chi^{2}$ & $d f$ & $p$ \\
\hline Caregiver & N.S. & 1.420 & 2 & .492 \\
\hline $\begin{array}{l}\text { Identification of the Caregiver } \\
\text { Spouse } \\
\text { Child } \\
\text { Parent } \\
\text { Other family Member } \\
\text { Non-Family Member }\end{array}$ & N.S. & 7.795 & 6 & .254 \\
\hline $\begin{array}{l}\text { Household Membership } \\
\text { Alone } \\
\text { Family }\end{array}$ & $\begin{array}{c}41 \% \\
46.2 \%\end{array}$ & 19.285 & 5 & $.002 *$ \\
\hline $\begin{array}{l}\text { Spouse or Significant Other } \\
\text { Parent } \\
\text { Child } \\
\text { Other Family Members }\end{array}$ & $\begin{array}{l}20 \% \\
\text { N.S. } \\
\text { N.S. } \\
6 \%\end{array}$ & $\begin{array}{l}10.777 \\
.180 \\
6.343 \\
9.076\end{array}$ & $\begin{array}{l}3 \\
3 \\
3 \\
3\end{array}$ & $\begin{array}{l}.013^{*} \\
.180 \\
.096 \\
.028^{*}\end{array}$ \\
\hline $\begin{array}{l}\text { Non-Family Members } \\
\text { Family and Non-Family }\end{array}$ & $\begin{array}{c}45.1 \% \\
0 \%\end{array}$ & & & \\
\hline
\end{tabular}

$* p$ values $\leq .05$ 
Table 55

Patient Utilization of Meals on Wheels Services \& Patient Location at the Beginning as Well as End of Care

\begin{tabular}{|l|c|c|c|}
\hline & \% of Those Who Used the Service & $\chi^{2}$ & $d f$ \\
\hline $\begin{array}{l}\text { Location at the Beginning of Care } \\
\text { Private Home }\end{array}$ & N.S. & 10.440 & 7 \\
$\quad \begin{array}{l}\text { Nursing Home/Skilled Nursing Facility } \\
\text { Hospital } \\
\text { Residential Care Place } \\
\text { Agency Inpatient/Residential Facility } \\
\text { Other }\end{array}$ & & .165 \\
\hline $\begin{array}{l}\text { Location at the End of Care } \\
\text { Private Home } \\
\text { Nursing Home/Skilled Nursing Facility } \\
\text { Hospital } \\
\begin{array}{l}\text { Residential Care Place } \\
\text { Agency Inpatient/Residential Facility }\end{array}\end{array}$ & N.S. & & \\
Other & & 4.931 & 7 \\
\hline
\end{tabular}

$* p$ values $\leq .05$ 
Complementary and alternative medicine services. Overall, $3.2 \%$ of patients utilized CAM services. Patient diagnosis, cognitive status, and total ADL needs were not significant. Hospice patients under routine home care represented $68.8 \%$ of patients that used CAM services. Patients who used these services had an average length of 90 service days. Patient payer source was not significantly related to use of CAM services. Patients who used this service had an average age of 75 years old. Patient gender was not significantly related to use of CAM services. Patient race, ethnicity, marital status, and veteran status was not significantly related to use of these services.

Patient caregiver status and identification of the caregiver were not significant. Patients who lived with a family member accounted for most of the patients who used this service (46.8\%). More specifically, those who had household membership with their spouse represented $31 \%$ of those who lived with a family member. Patients that lived in a private home at the beginning of care accounted for $49.4 \%$ of patients who used CAM services. At the end of care, patients that lived in a private home also represented the most of the patients that used CAM services (40.3\%). (see Tables 56- 60) 
Patient Utilization of CAM Services Based on Primary Diagnosis, Cognitive Status, \& Total ADL Needs

\begin{tabular}{|c|c|c|c|c|}
\hline & $\%$ of Those Who Used the Service & $\chi^{2}$ & df & $p$ \\
\hline $\begin{array}{l}\text { Diagnosis } \\
\text { Lung, Bronchial, or Tracheal Cancer } \\
\text { Heart Failure } \\
\text { Unspecified Chronic Airway Obstruction } \\
\text { Unknown Cause of Morbidity } \\
\end{array}$ & N.S. & 189.831 & 229 & .972 \\
\hline $\begin{array}{l}\text { Cognitive Status } \\
\text { No Cognitive Impairment } \\
\text { Occasional Reminders } \\
\text { Some Assistance } \\
\text { Great Deal of Assistance } \\
\text { Severe Cognitive Impairment }\end{array}$ & N.S. & 6.935 & 6 & .327 \\
\hline $\begin{array}{l}\text { Patient Total ADL Needs } \\
\text { None } \\
\text { One } \\
\text { Two } \\
\text { Three } \\
\text { Four } \\
\text { Five }\end{array}$ & N.S. & & 7 & .794 \\
\hline
\end{tabular}

$* p$ values $\leq .05$ 
Patient Utilization of CAM Services Based on Level of Care, Length of Service, \& Payer Source

\begin{tabular}{|c|c|c|c|c|}
\hline & $\%$ of Those Who Used the Service & $\chi^{2}$ & df & $p$ \\
\hline $\begin{array}{l}\text { Level of Care } \\
\text { Routine Homecare } \\
\text { Continuous Home Care } \\
\text { General Inpatient } \\
\text { Inpatient Respite } \\
\end{array}$ & $\begin{array}{c}68.8 \% \\
14.3 \% \\
14.3 \% \\
0 \% \\
\end{array}$ & 74.843 & 6 & $.000 *$ \\
\hline Length of Service & Average 90 days & 573.329 & 293 & $.000 *$ \\
\hline $\begin{array}{l}\text { Payer Source } \\
\text { Medicare } \\
\text { Medicaid } \\
\text { Tricare } \\
\text { Department of Veteran Affairs } \\
\text { Worker's Compensation } \\
\text { Other Government Funding } \\
\text { Private Insurance } \\
\text { Long-Term Care Insurance } \\
\text { Self-Pay } \\
\text { No Charge for Care } \\
\text { Undetermined Payer Source } \\
\text { Other }\end{array}$ & N.S. & 8.191 & 14 & .879 \\
\hline
\end{tabular}

$* p$ values $\leq .05$ 


\section{Table 58}

Patient Utilization of CAM Services, Age at Discharge, Gender, Race, Ethnicity, Marital Status, \& Veteran Status

\begin{tabular}{|c|c|c|c|c|}
\hline & $\%$ of Those Who Used the Service & $\chi^{2}$ & $\mathrm{df}$ & $p$ \\
\hline Patient Age at Discharge & Average 75 years old & 117.855 & 75 & $.001^{*}$ \\
\hline $\begin{array}{l}\text { Gender } \\
\text { Male } \\
\text { Female } \\
\end{array}$ & N.S. & 1.492 & 1 & .222 \\
\hline $\begin{array}{l}\text { Race } \\
\text { American Indian or Alaskan Native } \\
\text { Asian } \\
\text { Native Hawaiian or other Pacific Islander } \\
\text { Black or African American } \\
\text { White }\end{array}$ & $\begin{array}{l}\text { N.S. } \\
\text { N.S. } \\
\text { N.S. } \\
\text { N.S. } \\
\text { N.S. }\end{array}$ & $\begin{array}{c}.403 \\
.075 \\
.231 \\
2.948 \\
1.890 \\
\end{array}$ & $\begin{array}{l}1 \\
1 \\
1 \\
1 \\
1\end{array}$ & $\begin{array}{l}.526 \\
.784 \\
.631 \\
.086 \\
.169 \\
\end{array}$ \\
\hline $\begin{array}{l}\text { Ethnicity } \\
\text { Hispanic or Latino } \\
\text { White Non-Hispanic or Latino } \\
\text { Black Non-Hispanic or Latino } \\
\text { Other Non-Hispanic or Latino } \\
\end{array}$ & N.S. & 5.849 & 4 & .211 \\
\hline $\begin{array}{l}\text { Marital Status } \\
\text { Married } \\
\text { Widowed } \\
\text { Divorced } \\
\text { Separated } \\
\text { Never Married } \\
\text { Living with a Partner }\end{array}$ & N.S. & 5.586 & 6 & .471 \\
\hline Veteran & N.S. & 7.617 & 3 & .055 \\
\hline
\end{tabular}

$* p$ values $\leq .05$ 
Table 59

Patient Utilization of CAM Services, Caregiver Status, \& Household Membership

\begin{tabular}{|c|c|c|c|c|}
\hline & $\%$ of Those Who Used the Service & $\chi^{2}$ & $d f$ & $p$ \\
\hline Caregiver & N.S. & 1.319 & 2 & .517 \\
\hline $\begin{array}{l}\text { Identification of the Caregiver } \\
\text { Spouse } \\
\text { Child } \\
\text { Parent } \\
\text { Other family Member } \\
\text { Non-Family Member }\end{array}$ & N.S. & 12.21 & 6 & .051 \\
\hline $\begin{array}{l}\text { Household Membership } \\
\text { Alone } \\
\text { Family }\end{array}$ & $\begin{array}{l}10.4 \% \\
46.8 \%\end{array}$ & 14.416 & 5 & $.013 *$ \\
\hline $\begin{array}{l}\text { Spouse or Significant Other } \\
\text { Parent } \\
\text { Child } \\
\text { Other Family Members }\end{array}$ & $\begin{array}{c}31 \% \\
1 \% \\
11 \% \\
6 \%\end{array}$ & $\begin{array}{l}15.552 \\
14.613 \\
13.745 \\
13.879\end{array}$ & $\begin{array}{l}3 \\
3 \\
3 \\
3\end{array}$ & $\begin{array}{l}.001 * \\
.002 * \\
.003^{*} \\
.003^{*}\end{array}$ \\
\hline $\begin{array}{l}\text { Non-Family Members } \\
\text { Family and Non-Family }\end{array}$ & $\begin{array}{c}3.9 \% \\
0 \%\end{array}$ & & & \\
\hline
\end{tabular}

$* p$ values $\leq .05$ 
Patient Utilization of CAM Services \& Patient Location at the Beginning as Well as End of Care

\begin{tabular}{|c|c|c|c|c|}
\hline & $\%$ of Those Who Used the Service & $\chi^{2}$ & $d f$ & $p$ \\
\hline $\begin{array}{l}\text { Location at the Beginning of Care } \\
\text { Private Home } \\
\text { Nursing Home/Skilled Nursing Facility } \\
\text { Hospital } \\
\text { Residential Care Place } \\
\text { Agency Inpatient/Residential Facility } \\
\text { Other }\end{array}$ & $\begin{array}{c}49.4 \% \\
24.7 \% \\
5.2 \% \\
6.5 \% \\
9.1 \% \\
2.6 \% \\
\end{array}$ & 50.252 & 7 & $.000^{*}$ \\
\hline $\begin{array}{l}\text { Location at the End of Care } \\
\text { Private Home } \\
\text { Nursing Home/Skilled Nursing Facility } \\
\text { Hospital } \\
\text { Residential Care Place } \\
\text { Agency Inpatient/Residential Facility } \\
\text { Other }\end{array}$ & $\begin{array}{c}40.3 \% \\
29.9 \% \\
5.2 \% \\
6.5 \% \\
13 \% \\
2.6 \%\end{array}$ & 50.449 & 7 & $.000 *$ \\
\hline
\end{tabular}

$* p$ values $\leq .05$ 
Pastoral care services. Overall, 41.8\% of patients utilized pastoral care services. The majority of the patients who used this service had cancer, specifically either the lung, bronchial, or tracheal form of the disease (12.8\%). Those with no cognitive impairment utilized this service the most (26.4\%). Patients with four total ADL needs represented the most patients that used this service (28.6\%). Hospice patients under routine home care represented $76.9 \%$ of patients that used pastoral services. Patients who used this service had an average length of 90 service days. Medicare patients represented $80.8 \%$ of those who used this service.

Patient age and gender were not significantly related to pastoral care service. White and Black or African American racial identities were the only races significantly related to use of this service. White patients used this service the most (92.7\%). Furthermore, White non-Hispanics represented the highest amount of patients that used pastoral care services (87.4\%). Married patients accounted for $43.1 \%$ of patients who used this service and veterans represented $11.9 \%$.

Results indicated that $90.5 \%$ of patients who used pastoral services had a caregiver. Those with a spousal caregiver represented 32.3\% of patients who used this service. Patients who lived with a family member accounted for most of the patients who used this service (49.7\%). More specifically, those who had household membership with their spouse represented $29 \%$ of those who lived with a family member. Patients that lived in a private home at the beginning of care accounted for $58 \%$. At the end of care, patients that lived in a private home also represented the most of the patients that used pastoral care services (50.4\%). (see Tables 61-65) 
Table 61

Patient Utilization of Pastoral Care Services Based on Primary Diagnosis, Cognitive Status, \& Total ADL Needs

\begin{tabular}{|c|c|c|c|c|}
\hline & $\%$ of Those Who Used the Service & $\chi^{2}$ & df & $p$ \\
\hline $\begin{array}{l}\text { Diagnosis } \\
\text { Lung, Bronchial, or Tracheal Cancer } \\
\text { Heart Failure } \\
\text { Unspecified Chronic Airway Obstruction } \\
\text { Unknown Cause of Morbidity } \\
\text { Nutrition, Metabolism, or Developmental Disorders } \\
\text { Other Cerebral Degenerations }\end{array}$ & $\begin{array}{c}12.8 \% \\
7.4 \% \\
6.1 \% \\
5.8 \% \\
5.4 \% \\
5 \% \\
\end{array}$ & 732.402 & 229 & $.000^{*}$ \\
\hline $\begin{array}{l}\text { Cognitive Status } \\
\text { No Cognitive Impairment } \\
\text { Occasional Reminders } \\
\text { Some Assistance } \\
\text { Great Deal of Assistance } \\
\text { Severe Cognitive Impairment }\end{array}$ & $\begin{array}{l}26.4 \% \\
14.8 \% \\
16.6 \% \\
20.4 \% \\
13.2 \% \\
\end{array}$ & 114.273 & 6 & $.000^{*}$ \\
\hline $\begin{array}{l}\text { Patient Total ADL Needs } \\
\text { None } \\
\text { One } \\
\text { Two } \\
\text { Three } \\
\text { Four } \\
\text { Five }\end{array}$ & $\begin{array}{c}8.9 \% \\
8.3 \% \\
8 \% \\
19.8 \% \\
28.6 \% \\
21.7 \%\end{array}$ & 88.135 & 7 & $.000^{*}$ \\
\hline
\end{tabular}

$* p$ values $\leq .05$ 
Patient Utilization of Pastoral Care Services Based on Level of Care, Length of Service, \& Payer Source

\begin{tabular}{|c|c|c|c|c|}
\hline & $\%$ of Those Who Used the Service & $\chi^{2}$ & df & $p$ \\
\hline $\begin{array}{l}\text { Level of Care } \\
\text { Routine Homecare } \\
\text { Continuous Home Care } \\
\text { General Inpatient } \\
\text { Inpatient Respite }\end{array}$ & $\begin{array}{c}76.9 \% \\
3.8 \% \\
17.8 \% \\
1.1 \%\end{array}$ & 949.962 & 6 & $.000^{*}$ \\
\hline Length of Service & Average 90 days & 1222.663 & 293 & $.000^{*}$ \\
\hline $\begin{array}{l}\text { Payer Source } \\
\text { Medicare } \\
\text { Medicaid } \\
\text { Tricare } \\
\text { Department of Veteran Affairs } \\
\text { Worker's Compensation } \\
\text { Other Government Funding } \\
\text { Private Insurance } \\
\text { Long-Term Care Insurance } \\
\text { Self-Pay } \\
\text { No Charge for Care } \\
\text { Undetermined Payer Source } \\
\text { Other }\end{array}$ & $\begin{array}{l}80.8 \% \\
4 \% \\
.1 \% \\
1.8 \% \\
0 \% \\
.6 \% \\
7.6 \% \\
.2 \% \\
.8 \% \\
1.5 \% \\
.1 \% \\
.6 \%\end{array}$ & 154.955 & 14 & $.000^{*}$ \\
\hline
\end{tabular}

$* p$ values $\leq .05$ 
Table 63

Patient Utilization of Pastoral Care Services, Age at Discharge, Gender, Race, Ethnicity, Marital Status, \& Veteran Status

\begin{tabular}{|c|c|c|c|c|}
\hline & $\%$ of Those Who Used the Service & $\chi^{2}$ & df & $p$ \\
\hline Patient Age at Discharge & N.S. & 75.911 & 75 & .449 \\
\hline $\begin{array}{l}\text { Gender } \\
\text { Male } \\
\text { Female }\end{array}$ & N.S. & 1.606 & 1 & .205 \\
\hline $\begin{array}{l}\text { Race } \\
\text { American Indian or Alaskan Native } \\
\text { Asian } \\
\text { Native Hawaiian or other Pacific Islander } \\
\text { Black or African American } \\
\text { White } \\
\end{array}$ & $\begin{array}{l}\text { N.S. } \\
\text { N.S. } \\
\text { N.S. } \\
5.7 \% \\
92.7 \% \\
\end{array}$ & $\begin{array}{c}.003 \\
1.596 \\
2.188 \\
9.728 \\
11.775 \\
\end{array}$ & $\begin{array}{l}1 \\
1 \\
1 \\
1 \\
1\end{array}$ & $\begin{array}{l}.957 \\
.207 \\
.139 \\
.002^{*} \\
.001^{*}\end{array}$ \\
\hline $\begin{array}{l}\text { Ethnicity } \\
\text { Hispanic or Latino } \\
\text { White Non-Hispanic or Latino } \\
\text { Black Non-Hispanic or Latino } \\
\text { Other Non-Hispanic or Latino } \\
\end{array}$ & $\begin{array}{c}3.8 \% \\
87.4 \% \\
5.6 \% \\
1.5 \% \\
\end{array}$ & 18.369 & 4 & $.001 *$ \\
\hline $\begin{array}{l}\text { Marital Status } \\
\text { Married } \\
\text { Widowed } \\
\text { Divorced } \\
\text { Separated } \\
\text { Never Married } \\
\text { Living with a Partner } \\
\end{array}$ & $\begin{array}{c}43.1 \% \\
39.7 \% \\
6.6 \% \\
1 \% \\
5.2 \% \\
.7 \% \\
\end{array}$ & 62.028 & 6 & $.000^{*}$ \\
\hline Veteran & $11.9 \%$ & 21.432 & 3 & $.000 *$ \\
\hline
\end{tabular}


Table 64

Patient Utilization of Pastoral Care Services, Caregiver Status, \& Household Membership

\begin{tabular}{|c|c|c|c|c|}
\hline & $\%$ of Those Who Used the Service & $\chi^{2}$ & $d f$ & $p$ \\
\hline Caregiver & $90.5 \%$ & 20.004 & 2 & $.000^{*}$ \\
\hline $\begin{array}{l}\text { Identification of the Caregiver } \\
\text { Spouse } \\
\text { Child } \\
\text { Parent } \\
\text { Other family Member } \\
\text { Non-Family Member }\end{array}$ & $\begin{array}{c}32.3 \% \\
30.4 \% \\
1.6 \% \\
9.1 \% \\
17 \%\end{array}$ & 51.962 & 6 & $.000^{*}$ \\
\hline $\begin{array}{l}\text { Household Membership } \\
\text { Alone } \\
\text { Family }\end{array}$ & $\begin{array}{c}9.1 \% \\
49.7 \%\end{array}$ & 234.598 & 5 & $.000^{*}$ \\
\hline $\begin{array}{l}\text { Spouse or Significant Other } \\
\text { Parent } \\
\text { Child } \\
\text { Other Family Members }\end{array}$ & $\begin{array}{c}29 \% \\
1 \% \\
16 \% \\
4 \%\end{array}$ & $\begin{array}{l}224.346 \\
229.466 \\
228.763 \\
210.738\end{array}$ & $\begin{array}{l}3 \\
3 \\
3 \\
3\end{array}$ & $\begin{array}{l}.000^{*} \\
.000^{*} \\
.000^{*} \\
.000^{*}\end{array}$ \\
\hline $\begin{array}{l}\text { Non-Family Members } \\
\text { Family and Non-Family }\end{array}$ & $\begin{array}{l}4.2 \% \\
.4 \%\end{array}$ & & & \\
\hline
\end{tabular}

$* p$ values $\leq .05$ 
Table 65

Patient Utilization of Pastoral Care Services \& Patient Location at the Beginning as Well as End of Care

\begin{tabular}{|c|c|c|c|c|}
\hline & $\%$ of Those Who Used the Service & $\chi^{2}$ & $d f$ & $p$ \\
\hline $\begin{array}{l}\text { Location at the Beginning of Care } \\
\text { Private Home } \\
\text { Nursing Home/Skilled Nursing Facility } \\
\text { Hospital } \\
\text { Residential Care Place } \\
\text { Agency Inpatient/Residential Facility } \\
\text { Other }\end{array}$ & $\begin{array}{c}58 \% \\
21.3 \% \\
7.1 \% \\
4.3 \% \\
8.3 \% \\
.8 \%\end{array}$ & 960.670 & 7 & $.000 *$ \\
\hline $\begin{array}{l}\text { Location at the End of Care } \\
\text { Private Home } \\
\text { Nursing Home/Skilled Nursing Facility } \\
\text { Hospital } \\
\text { Residential Care Place } \\
\text { Agency Inpatient/Residential Facility } \\
\text { Other }\end{array}$ & $\begin{array}{c}50.4 \\
24 \% \\
7.5 \% \\
4.5 \% \\
12.3 \% \\
1.2 \%\end{array}$ & 965.212 & 7 & $.000 *$ \\
\hline
\end{tabular}

$* p$ values $\leq .05$ 
Volunteer services. Overall, 19.8\% of patients utilized volunteer services. The majority of the patients who used this service had cancer, specifically either the lung, bronchial, or tracheal form of the disease (11.5\%). Those with no cognitive impairment utilized volunteer services the most (29\%). Patients with four total ADL needs represented the most patients that used this service (31.5\%). Hospice patients under routine home care represented $77.2 \%$ of patients that used volunteer services. Patients who used this service had an average length of 110 service days. Medicare patients represented $81.4 \%$ of those who used this service. The average age of patients who used this service was 75 years old. Patient gender was not significant. Only White and Asian racial identities were significantly related to volunteer service utilization. White patients used this service the most (93.7\%). Furthermore, White non-Hispanics represented the highest amount of patients that used volunteer services (91\%). Married patients accounted for $43.2 \%$ of patients who used this service. Veterans represented $13.2 \%$ of patients who used this service.

Results indicated that $91.4 \%$ of patients who used volunteer services had a caregiver. Those with a spousal caregiver represented $33.4 \%$ of patients who used this service. Patients who lived alone accounted for most of the patients who used this service (55.3\%). Patients that lived in a private home at the beginning of care accounted for 63.3\% and those that lived in a private home also represented the most of the patients that used volunteer services (63.3\%). (see Tables 66- 70) 
Patient Utilization of Volunteer Services Based on Primary Diagnosis, Cognitive Status, \& Total ADL Needs

\begin{tabular}{|c|c|c|c|c|}
\hline & $\%$ of Those Who Used the Service & $\chi^{2}$ & $\mathrm{df}$ & $p$ \\
\hline $\begin{array}{l}\text { Diagnosis } \\
\text { Lung, Bronchial, or Tracheal Cancer } \\
\text { Heart Failure } \\
\text { Unspecified Chronic Airway Obstruction } \\
\text { Other organic psychotic chronic conditions } \\
\text { Unknown Cause of Morbidity } \\
\text { Nutrition, Metabolism, or Development Disorders }\end{array}$ & $\begin{array}{l}11.5 \% \\
7.3 \% \\
6.7 \% \\
6.5 \% \\
6.5 \% \\
6.1 \% \\
\end{array}$ & 335.592 & 229 & $.000 *$ \\
\hline $\begin{array}{l}\text { Cognitive Status } \\
\text { No Cognitive Impairment } \\
\text { Occasional Reminders } \\
\text { Some Assistance } \\
\text { Great Deal of Assistance } \\
\text { Severe Cognitive Impairment }\end{array}$ & $\begin{array}{c}29 \% \\
16.1 \% \\
16.9 \% \\
21.3 \% \\
10.2 \%\end{array}$ & 23.751 & 6 & $.001 *$ \\
\hline $\begin{array}{l}\text { Patient Total ADL Needs } \\
\text { None } \\
\text { One } \\
\text { Two } \\
\text { Three } \\
\text { Four } \\
\text { Five }\end{array}$ & $\begin{array}{c}13.2 \% \\
7.2 \% \\
8.4 \% \\
15.7 \% \\
31.5 \% \\
23.6 \%\end{array}$ & 37.329 & 7 & $.000 *$ \\
\hline
\end{tabular}

$* p$ values $\leq .05$ 
Patient Utilization of Volunteer Services Based on Level of Care, Length of Service, \& Payer Source

\begin{tabular}{|c|c|c|c|c|}
\hline & $\%$ of Those Who Used the Service & $\chi^{2}$ & $\mathrm{df}$ & $p$ \\
\hline $\begin{array}{l}\text { Level of Care } \\
\text { Routine Homecare } \\
\text { Continuous Home Care } \\
\text { General Inpatient } \\
\text { Inpatient Respite } \\
\end{array}$ & $\begin{array}{c}77.2 \% \\
2.1 \% \\
14.8 \% \\
4.4 \% \\
\end{array}$ & 319.212 & 6 & $.000^{*}$ \\
\hline Length of Service & Average 110 days & 880.974 & 293 & $.000^{*}$ \\
\hline $\begin{array}{l}\text { Payer Source } \\
\text { Medicare } \\
\text { Medicaid } \\
\text { Tricare } \\
\text { Department of Veteran Affairs } \\
\text { Worker's Compensation } \\
\text { Other Government Funding } \\
\text { Private Insurance } \\
\text { Long-Term Care Insurance } \\
\text { Self-Pay } \\
\text { No Charge for Care } \\
\text { Undetermined Payer Source } \\
\text { Other }\end{array}$ & $\begin{array}{c}81.4 \% \\
3.1 \% \\
.2 \% \\
1.5 \% \\
0 \% \\
.4 \% \\
4.8 \% \\
0 \% \\
.6 \% \\
4.2 \% \\
.2 \% \\
.4 \%\end{array}$ & 108.449 & 14 & $.000^{*}$ \\
\hline
\end{tabular}

$* p$ values $\leq .05$ 
Patient Utilization of Volunteer Services, Age at Discharge, Gender, Race, Ethnicity, Marital Status, \& Veteran Status

\begin{tabular}{|c|c|c|c|c|}
\hline & $\%$ of Those Who Used the Service & $\chi^{2}$ & df & $p$ \\
\hline Patient Age at Discharge & Average age 75 & 107.964 & 75 & $.008 *$ \\
\hline $\begin{array}{l}\text { Gender } \\
\text { Male } \\
\text { Female } \\
\end{array}$ & N.S. & .117 & 1 & .732 \\
\hline $\begin{array}{l}\text { Race } \\
\text { American Indian or Alaskan Native } \\
\text { Asian } \\
\text { Native Hawaiian or other Pacific Islander } \\
\text { Black or African American } \\
\text { White } \\
\end{array}$ & $\begin{array}{l}\text { N.S. } \\
0 \% \\
\text { N.S. } \\
\text { N.S. } \\
93.7 \% \\
\end{array}$ & $\begin{array}{c}.701 \\
5.998 \\
.136 \\
3.712 \\
8.345 \\
\end{array}$ & $\begin{array}{l}1 \\
1 \\
1 \\
1 \\
1\end{array}$ & $\begin{array}{l}.402 \\
.014^{*} \\
.712 \\
.054 \\
.004^{*}\end{array}$ \\
\hline $\begin{array}{l}\text { Ethnicity } \\
\text { Hispanic or Latino } \\
\text { White Non-Hispanic or Latino } \\
\text { Black Non-Hispanic or Latino } \\
\text { Other Non-Hispanic or Latino } \\
\end{array}$ & $\begin{array}{c}2.3 \% \\
91 \% \\
5.6 \% \\
.6 \% \\
\end{array}$ & 26.045 & 4 & .000 \\
\hline $\begin{array}{l}\text { Marital Status } \\
\text { Married } \\
\text { Widowed } \\
\text { Divorced } \\
\text { Separated } \\
\text { Never Married } \\
\text { Living with a Partner } \\
\end{array}$ & $\begin{array}{c}43.2 \% \\
40.9 \% \\
7.1 \% \\
4.4 \% \\
.6 \% \\
1.3 \% \\
\end{array}$ & 34.211 & 6 & $.000^{*}$ \\
\hline Veteran & $13.2 \%$ & 19.119 & 3 & $.000 *$ \\
\hline
\end{tabular}

$* p$ values $\leq .05$ 
Table 69

Patient Utilization of Volunteer Services, Caregiver Status, \& Household Membership

\begin{tabular}{|c|c|c|c|c|}
\hline & $\%$ of Those Who Used the Service & $\chi^{2}$ & $d f$ & $p$ \\
\hline Caregiver & $91.4 \%$ & 11.007 & 2 & $.004 *$ \\
\hline $\begin{array}{l}\text { Identification of the Caregiver } \\
\text { Spouse } \\
\text { Child } \\
\text { Parent } \\
\text { Other family Member } \\
\text { Non-Family Member } \\
\end{array}$ & $\begin{array}{c}33.4 \% \\
29.6 \% \\
1.7 \% \\
9 \% \\
17.5 \% \\
\end{array}$ & 21.853 & 6 & $.001 *$ \\
\hline $\begin{array}{l}\text { Household Membership } \\
\text { Alone } \\
\text { Family }\end{array}$ & $\begin{array}{l}55.3 \% \\
9.4 \%\end{array}$ & 43.588 & 5 & $.000 *$ \\
\hline $\begin{array}{l}\text { Spouse or Significant Other } \\
\text { Parent } \\
\text { Child } \\
\text { Other Family Members }\end{array}$ & $\begin{array}{c}32 \% \\
1 \% \\
16 \% \\
6 \%\end{array}$ & $\begin{array}{l}36.565 \\
40.375 \\
31.290 \\
28.858\end{array}$ & $\begin{array}{l}3 \\
3 \\
3 \\
3\end{array}$ & $\begin{array}{l}.000 * \\
.000 * \\
.000 * \\
.000 *\end{array}$ \\
\hline $\begin{array}{l}\text { Non-Family Members } \\
\text { Family and Non-Family }\end{array}$ & $\begin{array}{l}4 \% \\
.2 \%\end{array}$ & & & \\
\hline
\end{tabular}

$* p$ values $\leq .05$ 
Table 70

Patient Utilization of Volunteer Services \& Patient Location at the Beginning as Well as End of Care

\begin{tabular}{|c|c|c|c|c|}
\hline & $\%$ of Those Who Used the Service & $\chi^{2}$ & $d f$ & $p$ \\
\hline $\begin{array}{l}\text { Location at the Beginning of Care } \\
\text { Private Home } \\
\text { Nursing Home/Skilled Nursing Facility } \\
\text { Hospital } \\
\text { Residential Care Place } \\
\text { Agency Inpatient/Residential Facility } \\
\text { Other }\end{array}$ & $\begin{array}{c}63.3 \% \\
21.9 \% \\
3.5 \% \\
3.3 \% \\
6.3 \% \\
.6 \% \\
\end{array}$ & 333.150 & 7 & $.000^{*}$ \\
\hline $\begin{array}{l}\text { Location at the End of Care } \\
\text { Private Home } \\
\text { Nursing Home/Skilled Nursing Facility } \\
\text { Hospital } \\
\text { Residential Care Place } \\
\text { Agency Inpatient/Residential Facility } \\
\text { Other }\end{array}$ & $\begin{array}{c}50.7 \% \\
26.5 \% \\
6.3 \% \\
3.5 \% \\
11.1 \% \\
.8 \%\end{array}$ & 324.880 & 7 & $.000^{*}$ \\
\hline
\end{tabular}

$* p$ values $\leq .05$ 


\section{Caregiver Support Service Utilization}

Bereavement services. Overall, 53.5\% of patients had caregivers that utilized bereavement services. The majority of the patients had cancer diagnosis, specifically either the lung, bronchial, or tracheal form of the disease (14.7\%). Those with no cognitive impairment had a caregiver that used the service the most (27.2\%). Patients with four total ADL needs represented the most patients with caregivers that used this service (24.7\%). Hospice patients under routine home care represented $76.2 \%$ of patients with caregivers that used this service.

Patients with caregivers that who used bereavement services had an average length of 60 service days. Medicare patients represented $79.9 \%$ of those with caregivers that used this service. Patient age was not significant. Females accounted for the most patients with caregivers who used this service. Asian, Black or African American, and White racial identity were significantly related to caregiver use of bereavement services. White patients used this service the most (93.7\%). Furthermore, White non-Hispanics represented the highest amount of patients with caregivers that used bereavement services (89.1\%). Married patients accounted for $44.9 \%$ of patients with caregivers that used this service. Veterans represented $6 \%$ of patients with a caregiver that used this service.

Patients with spousal caregivers represented $44 \%$ of patients who used this service. Patients who lived with a family member accounted for most of the patients with caregivers that used this service (52.7\%). More specifically, those who had household membership with their spouse represented $32 \%$ of those who lived with a family member. Patients that lived in a private home at the beginning of care accounted for $60.2 \%$ and 
those that lived in a private home at the end of care also represented the most patients that had a caregiver that used bereavement services (60.2\%). (see Tables 71- 75)

Table 71

Caregiver Utilization of Bereavement Services Based on Patient Primary Diagnosis, Cognitive Status, \& Total ADL Needs

\begin{tabular}{|c|c|c|c|c|}
\hline & $\%$ of Those Who Used the Service & $\chi^{2}$ & df & $p$ \\
\hline $\begin{array}{l}\text { Diagnosis } \\
\text { Lung, Bronchial, or Tracheal Cancer } \\
\text { Heart Failure } \\
\text { Unspecified Chronic Airway Obstruction } \\
\text { Other Organic Psychotic Conditions }\end{array}$ & $\begin{array}{c}14.7 \% \\
8 \% \\
6 \% \\
5.3 \%\end{array}$ & 2064.221 & 687 & $.000^{*}$ \\
\hline $\begin{array}{l}\text { Cognitive Status } \\
\text { No Cognitive Impairment } \\
\text { Occasional Reminders } \\
\text { Some Assistance } \\
\text { Great Deal of Assistance } \\
\text { Severe Cognitive Impairment }\end{array}$ & $\begin{array}{l}27.2 \% \\
19.5 \% \\
14.7 \% \\
11.5 \% \\
5.4 \% \\
\end{array}$ & 606.262 & 18 & $.000^{*}$ \\
\hline $\begin{array}{l}\text { Patient Total ADL Needs } \\
\text { None } \\
\text { One } \\
\text { Two } \\
\text { Three } \\
\text { Four } \\
\text { Five }\end{array}$ & $\begin{array}{c}8.1 \% \\
11.4 \% \\
8.6 \% \\
20 \% \\
24.7 \% \\
22.3 \%\end{array}$ & 699.906 & 21 & $.000^{*}$ \\
\hline
\end{tabular}

$* p$ values $\leq .05$ 
Table 72

Caregiver Utilization of Bereavement Services Based on Patient Level of Care, Length of Service, \& Payer Source

\begin{tabular}{|c|c|c|c|c|}
\hline & $\%$ of Those Who Used the Service & $\chi^{2}$ & df & $p$ \\
\hline $\begin{array}{l}\text { Level of Care } \\
\text { Routine Homecare } \\
\text { Continuous Home Care } \\
\text { General Inpatient } \\
\text { Inpatient Respite } \\
\end{array}$ & $\begin{array}{c}76.2 \% \\
4.4 \% \\
17.4 \% \\
1.1 \% \\
\end{array}$ & 2131.216 & 18 & $.000^{*}$ \\
\hline Length of Service & Average 60 days & 1983.957 & 879 & $.000 *$ \\
\hline $\begin{array}{l}\text { Payer Source } \\
\text { Medicare } \\
\text { Medicaid } \\
\text { Tricare } \\
\text { Department of Veteran Affairs } \\
\text { Worker's Compensation } \\
\text { Other Government Funding } \\
\text { Private Insurance } \\
\text { Long-Term Care Insurance } \\
\text { Self-Pay } \\
\text { No Charge for Care } \\
\text { Undetermined Payer Source } \\
\text { Other }\end{array}$ & $\begin{array}{l}79.9 \% \\
3.7 \% \\
.4 \% \\
1.5 \% \\
0 \% \\
.3 \% \\
8.2 \% \\
.2 \% \\
1 \% \\
2.2 \% \\
.2 \% \\
.6 \%\end{array}$ & 294.577 & 42 & $.000^{*}$ \\
\hline
\end{tabular}

$* p$ values $\leq .05$ 


\section{Table 73}

Caregiver Utilization of Bereavement Services Based on Patient Age at Discharge, Gender, Race, Ethnicity, Marital Status, \& Veteran Status

\begin{tabular}{|c|c|c|c|c|}
\hline & $\%$ of Those Who Used the Service & $\chi^{2}$ & $\mathrm{df}$ & $p$ \\
\hline Patient Age at Discharge & N.S. & 177.112 & 105 & .065 \\
\hline $\begin{array}{l}\text { Gender } \\
\text { Male } \\
\text { Female }\end{array}$ & $\begin{array}{l}46.6 \% \\
53.4 \%\end{array}$ & 13.232 & 3 & $.004^{*}$ \\
\hline $\begin{array}{l}\text { Race } \\
\text { American Indian or Alaskan Native } \\
\text { Asian } \\
\text { Native Hawaiian or other Pacific Islander } \\
\text { Black or African American } \\
\text { White } \\
\end{array}$ & $\begin{array}{c}\text { N.S. } \\
1 \% \\
\text { N.S. } \\
4.6 \% \\
93.7 \% \\
\end{array}$ & $\begin{array}{c}7.252 \\
18.610 \\
1.914 \\
39.137 \\
37.441 \\
\end{array}$ & $\begin{array}{l}3 \\
3 \\
3 \\
3 \\
3 \\
\end{array}$ & $\begin{array}{l}.064 \\
.000^{*} \\
.591 \\
.000^{*} \\
.000^{*}\end{array}$ \\
\hline $\begin{array}{l}\text { Ethnicity } \\
\text { Hispanic or Latino } \\
\text { White Non-Hispanic or Latino } \\
\text { Black Non-Hispanic or Latino } \\
\text { Other Non-Hispanic or Latino } \\
\end{array}$ & $\begin{array}{l}3.2 \% \\
89.1 \% \\
4.6 \% \\
1.5 \% \\
\end{array}$ & 228.383 & 12 & $.000^{*}$ \\
\hline $\begin{array}{l}\text { Marital Status } \\
\text { Married } \\
\text { Widowed } \\
\text { Divorced } \\
\text { Separated } \\
\text { Never Married } \\
\text { Living with a Partner } \\
\end{array}$ & $\begin{array}{c}44.9 \% \\
38.2 \% \\
6.8 \% \\
.5 \% \\
5.3 \% \\
.9 \% \\
\end{array}$ & 143.139 & 18 & $.000^{*}$ \\
\hline Veteran & $6 \%$ & 37.026 & 9 & $.000 *$ \\
\hline
\end{tabular}


Caregiver Utilization of Bereavement Services Based on Patient Caregiver Identification \& Household Membership

\begin{tabular}{|c|c|c|c|c|}
\hline & $\%$ of Those Who Used the Service & $\chi^{2}$ & $d f$ & $p$ \\
\hline $\begin{array}{l}\text { Identification of the Caregiver } \\
\text { Spouse } \\
\text { Child } \\
\text { Parent } \\
\text { Other family Member } \\
\text { Non-Family Member } \\
\end{array}$ & $\begin{array}{c}44 \% \\
27 \% \\
6 \% \\
9 \% \\
12 \% \\
\end{array}$ & 351.106 & 18 & $.000^{*}$ \\
\hline $\begin{array}{l}\text { Household Membership } \\
\text { Alone } \\
\text { Family }\end{array}$ & $\begin{array}{c}7.4 \% \\
52.7 \%\end{array}$ & 378.502 & 15 & $.000^{*}$ \\
\hline $\begin{array}{l}\text { Spouse or Significant Other } \\
\text { Parent } \\
\text { Child } \\
\text { Other Family Members }\end{array}$ & $\begin{array}{c}32 \% \\
1 \% \\
16 \% \\
5 \%\end{array}$ & $\begin{array}{l}338.617 \\
311.337 \\
308.275 \\
286.318\end{array}$ & $\begin{array}{l}9 \\
9 \\
9 \\
9\end{array}$ & $\begin{array}{l}.000 * \\
.000 * \\
.000 * \\
.000 *\end{array}$ \\
\hline $\begin{array}{l}\text { Non-Family Members } \\
\text { Family and Non-Family }\end{array}$ & $\begin{array}{l}4.5 \% \\
.6 \%\end{array}$ & & & \\
\hline
\end{tabular}

$* p$ values $\leq .05$ 
Caregiver Utilization of Bereavement Services Based on Patient Location at the Beginning as Well as End of Care

\begin{tabular}{|c|c|c|c|c|}
\hline & $\%$ of Those Who Used the Service & $\chi^{2}$ & $d f$ & $p$ \\
\hline $\begin{array}{l}\text { Location at the Beginning of Care } \\
\text { Private Home } \\
\text { Nursing Home/Skilled Nursing Facility } \\
\text { Hospital } \\
\text { Residential Care Place } \\
\text { Agency Inpatient/Residential Facility } \\
\text { Other }\end{array}$ & $\begin{array}{c}60.2 \% \\
19.6 \% \\
8 \% \\
3.5 \% \\
7.2 \% \\
.8 \% \\
\end{array}$ & 2347.238 & 21 & $.000^{*}$ \\
\hline $\begin{array}{l}\text { Location at the End of Care } \\
\text { Private Home } \\
\text { Nursing Home/Skilled Nursing Facility } \\
\text { Hospital } \\
\text { Residential Care Place } \\
\text { Agency Inpatient/Residential Facility } \\
\text { Other }\end{array}$ & $\begin{array}{c}53 \% \\
22.2 \% \\
8.4 \% \\
3.6 \% \\
10.9 \% \\
1.3 \%\end{array}$ & 2346.525 & 21 & $.000^{*}$ \\
\hline
\end{tabular}

$* p$ values $\leq .05$ 
Caregiver health and wellness services. Overall, 22.2\% of patients had caregivers that utilized health and wellness services. The majority of the patients had cancer diagnosis, specifically either the lung, bronchial, or tracheal form of the disease (10.5\%). Those with no cognitive impairment had a caregiver that used the service the most (29.7\%). Patients with four total ADL needs represented the most patients with caregivers that used this service (27.9\%). Hospice patients under routine home care represented 71.4\% of patients with caregivers that used this service.

Patient length of service was not significant. Medicare patients represented 75.1\% of those with caregivers that used this service. The average age of patients that had a caregiver that used this service. Patient gender was not significant. Asian and American Indian or Alaskan Native racial identity were significantly related to caregiver use of health and wellness services. Asian patients used this service the most (.7\%). White nonHispanics represented the highest amount of patients with caregivers that used health and wellness services (87.9\%). Married patients accounted for $46.9 \%$ of patients with caregivers that used this service. Veterans represented $7.9 \%$ of patients with a caregiver that used this service.

Patients with spousal caregivers represented $37 \%$ of patients who used this service. Patients who lived with a family member accounted for most of the patients with caregivers that used this service (62.6\%). More specifically, those who had household membership with their spouse represented $37 \%$ of those who lived with a family member. Patients that lived in a private home at the beginning of care accounted for $58.3 \%$ and 
those that lived in a private home at the end of care also represented the most patients that had a caregiver that used health and wellness services (52.1\%). (see Tables 76-80)

Table 76

Caregiver Utilization of Health \& Wellness Services Based on Patient Primary Diagnosis, Cognitive Status, \& Total ADL Needs

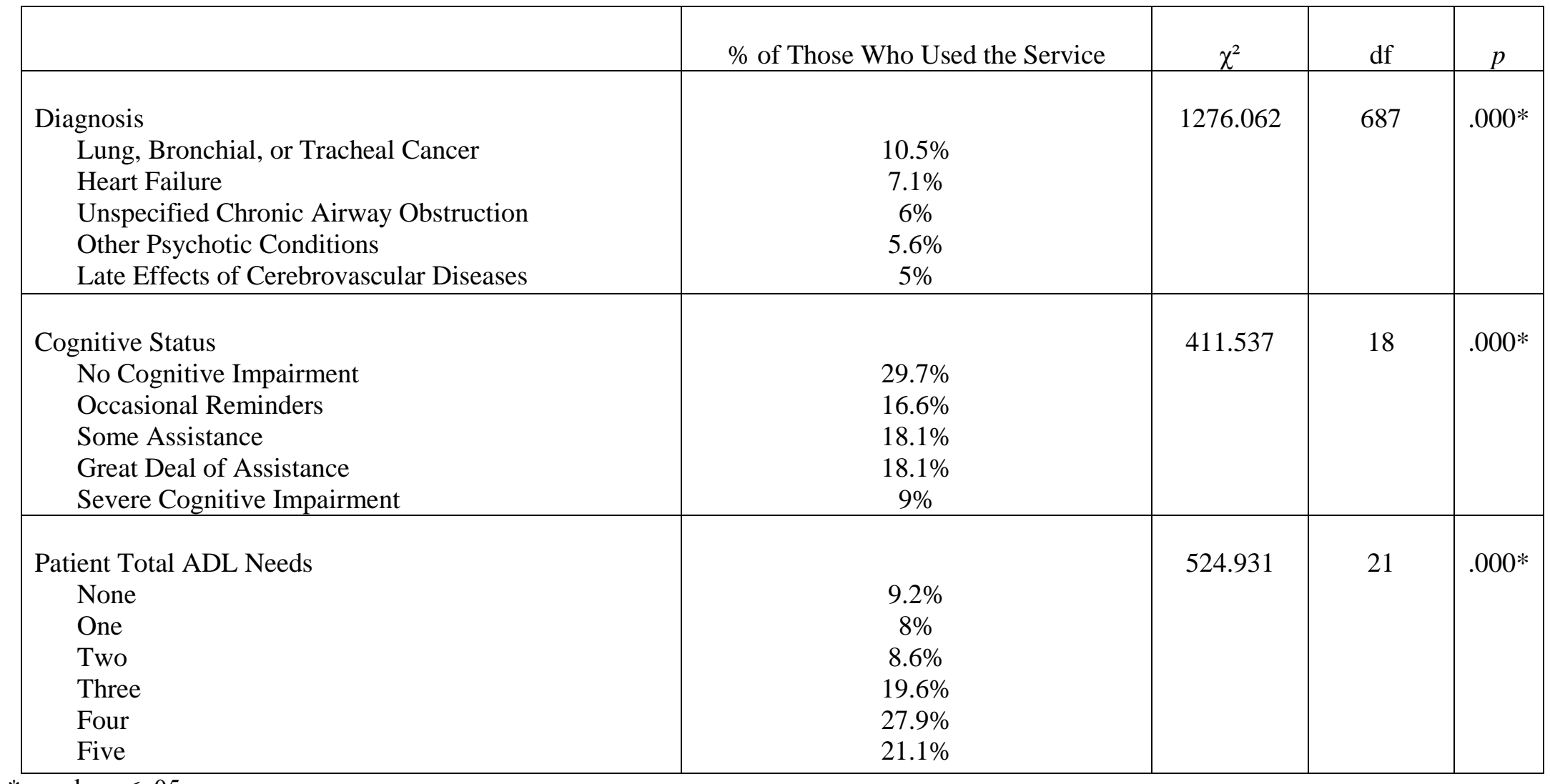

$* p$ values $\leq .05$ 
Caregiver Utilization of Health \& Wellness Services Based on Patient Level of Care, Length of Service, \& Payer Source

\begin{tabular}{|c|c|c|c|c|}
\hline & $\%$ of Those Who Used the Service & $\chi^{2}$ & df & $p$ \\
\hline $\begin{array}{l}\text { Level of Care } \\
\text { Routine Homecare } \\
\text { Continuous Home Care } \\
\text { General Inpatient } \\
\text { Inpatient Respite } \\
\end{array}$ & $\begin{array}{c}71.4 \% \\
3 \% \\
10.5 \% \\
.6 \%\end{array}$ & 787.030 & 18 & $.000^{*}$ \\
\hline Length of Service & N.S. & 745.192 & 879 & 1.000 \\
\hline $\begin{array}{l}\text { Payer Source } \\
\text { Medicare } \\
\text { Medicaid } \\
\text { Tricare } \\
\text { Department of Veteran Affairs } \\
\text { Worker's Compensation } \\
\text { Other Government Funding } \\
\text { Private Insurance } \\
\text { Long-Term Care Insurance } \\
\text { Self-Pay } \\
\text { No Charge for Care } \\
\text { Undetermined Payer Source } \\
\text { Other }\end{array}$ & $\begin{array}{c}75.1 \% \\
1.9 \% \\
0 \% \\
1.7 \% \\
0 \% \\
.4 \% \\
7.7 \% \\
.2 \% \\
3.2 \% \\
3.2 \% \\
0 \% \\
.4 \%\end{array}$ & 87.484 & 42 & $.000 *$ \\
\hline
\end{tabular}

$* p$ values $\leq .05$ 
Table 78

Caregiver Utilization of Health \& Wellness Services Based on Patient Age at Discharge, Gender, Race, Ethnicity, Marital Status, \& Veteran Status

\begin{tabular}{|c|c|c|c|c|}
\hline & $\%$ of Those Who Used the Service & $\chi^{2}$ & df & $p$ \\
\hline Patient Age at Discharge & Average Age 75 & 191.347 & 150 & $.013 *$ \\
\hline $\begin{array}{l}\text { Gender } \\
\text { Male } \\
\text { Female }\end{array}$ & N.S. & 5.263 & 3 & .154 \\
\hline $\begin{array}{l}\text { Race } \\
\text { American Indian or Alaskan Native } \\
\text { Asian } \\
\text { Native Hawaiian or other Pacific Islander } \\
\text { Black or African American } \\
\text { White }\end{array}$ & $\begin{array}{l}0 \% \\
.7 \% \\
\text { N.S. } \\
\text { N.S. } \\
\text { N.S. }\end{array}$ & $\begin{array}{l}11.007 \\
18.873 \\
2.105 \\
1.556 \\
4.665 \\
\end{array}$ & $\begin{array}{l}3 \\
3 \\
3 \\
3 \\
3\end{array}$ & $\begin{array}{l}.012 * \\
.000 * \\
.551 \\
.669 \\
.198\end{array}$ \\
\hline $\begin{array}{l}\text { Ethnicity } \\
\text { Hispanic or Latino } \\
\text { White Non-Hispanic or Latino } \\
\text { Black Non-Hispanic or Latino } \\
\text { Other Non-Hispanic or Latino }\end{array}$ & $\begin{array}{c}4.1 \% \\
87.9 \% \\
6.7 \% \\
.7 \% \\
\end{array}$ & 191.350 & 12 & $.000 *$ \\
\hline $\begin{array}{l}\text { Marital Status } \\
\text { Married } \\
\text { Widowed } \\
\text { Divorced } \\
\text { Separated } \\
\text { Never Married } \\
\text { Living with a Partner } \\
\end{array}$ & $\begin{array}{c}46.9 \% \\
33.6 \% \\
7.3 \% \\
.7 \% \\
7.3 \% \\
.9 \% \\
\end{array}$ & 56.652 & 18 & $.000 *$ \\
\hline Veteran & $7.9 \%$ & 35.370 & 9 & $.000 *$ \\
\hline
\end{tabular}


Table 79

Caregiver Utilization of Health \& Wellness Services Based on Patient Caregiver Identification \& Household Membership

\begin{tabular}{|c|c|c|c|c|}
\hline & $\%$ of Those Who Used the Service & $\chi^{2}$ & $d f$ & $p$ \\
\hline $\begin{array}{l}\text { Identification of the Caregiver } \\
\text { Spouse } \\
\text { Child } \\
\text { Parent } \\
\text { Other family Member } \\
\text { Non-Family Member } \\
\end{array}$ & $\begin{array}{c}37 \% \\
30 \% \\
4 \% \\
9 \% \\
15 \% \\
\end{array}$ & 132.321 & 18 & $.000^{*}$ \\
\hline $\begin{array}{l}\text { Household Membership } \\
\text { Alone } \\
\text { Family }\end{array}$ & $\begin{array}{l}10.2 \% \\
62.6 \%\end{array}$ & 44.269 & 15 & $.000^{*}$ \\
\hline $\begin{array}{l}\text { Spouse or Significant Other } \\
\text { Parent } \\
\text { Child } \\
\text { Other Family Members }\end{array}$ & $\begin{array}{c}37 \% \\
2 \% \\
18 \% \\
6 \%\end{array}$ & $\begin{array}{l}29.551 \\
21.995 \\
21.095 \\
17.208\end{array}$ & $\begin{array}{l}9 \\
9 \\
9 \\
9\end{array}$ & $\begin{array}{l}.001 * \\
.009 * \\
.012 * \\
.046 *\end{array}$ \\
\hline $\begin{array}{l}\text { Non-Family Members } \\
\text { Family and Non-Family }\end{array}$ & $\begin{array}{c}4.5 \% \\
.4 \%\end{array}$ & & & \\
\hline
\end{tabular}

$* p$ values $\leq .05$ 
Table 80

Caregiver Utilization of Health \& Wellness Based on Patient Location at the Beginning as Well as End of Care

\begin{tabular}{|c|c|c|c|c|}
\hline & $\%$ of Those Who Used the Service & $\chi^{2}$ & $d f$ & $p$ \\
\hline $\begin{array}{l}\text { Location at the Beginning of Care } \\
\text { Private Home } \\
\text { Nursing Home/Skilled Nursing Facility } \\
\text { Hospital } \\
\text { Residential Care Place } \\
\text { Agency Inpatient/Residential Facility } \\
\text { Other }\end{array}$ & $\begin{array}{c}58.3 \% \\
12 \% \\
6.5 \% \\
3 \% \\
4.7 \% \\
.9 \%\end{array}$ & 1012.654 & 21 & $.000 *$ \\
\hline $\begin{array}{l}\text { Location at the End of Care } \\
\text { Private Home } \\
\text { Nursing Home/Skilled Nursing Facility } \\
\text { Hospital } \\
\text { Residential Care Place } \\
\text { Agency Inpatient/Residential Facility } \\
\text { Other }\end{array}$ & $\begin{array}{c}52.1 \% \\
15.1 \% \\
5.8 \% \\
3.6 \% \\
6.9 \% \\
1.9 \%\end{array}$ & 1015.998 & 21 & $.000 *$ \\
\hline
\end{tabular}

$* p$ values $\leq .05$ 
Spiritual care services. Overall, $43.3 \%$ of patients had caregivers that utilized spiritual care services. The majority of the patients had cancer diagnosis, specifically either the lung, bronchial, or tracheal form of the disease (13.3\%). Those with no cognitive impairment had a caregiver that used the service the most (26.4\%). Patients with four total ADL needs represented the most patients with caregivers that used this service (26\%).

Hospice patients under routine home care represented $78.1 \%$ of patients with caregivers that used this service. Patients with caregivers that who used spiritual care services had an average length of 80 service days. Medicare patients represented 79.8\% of those with caregivers that used this service. Patients with a caregiver that used spiritual care services had the average age of 75 years. Patient gender was not significant. Asian and White racial identity were significantly related to caregiver use of spiritual services. White patients used this service the most (92.2\%). Furthermore, White non-Hispanics represented the highest amount of patients with caregivers that used this service (88.1\%). Married patients accounted for $43.6 \%$ of patients with caregivers that used this service. Veterans represented $7.3 \%$ of patients with a caregiver that used this service.

Patients with spousal caregivers represented $33 \%$ of patients who used this service. Patients who lived with a family member accounted for most of the patients with caregivers that used this service (60.9\%). More specifically, those who had household membership with their spouse represented 31\% of those who lived with a family member. Patients that lived in a private home at the beginning of care accounted for $60.9 \%$ and 
those that lived in a private home at the end of care also represented the most patients that had a caregiver that used spiritual services (53.8\%). (see Tables $81-85)$

Table 81

Caregiver Utilization of Spiritual Services Based on Patient Primary Diagnosis, Cognitive Status, \& Total ADL Needs

\begin{tabular}{|c|c|c|c|c|}
\hline & $\%$ of Those Who Used the Service & $\chi^{2}$ & $\mathrm{df}$ & $p$ \\
\hline $\begin{array}{l}\text { Diagnosis } \\
\text { Lung, Bronchial, or Tracheal Cancer } \\
\text { Heart Failure } \\
\text { Unspecified Chronic Airway Obstruction } \\
\text { Other Psychotic Chronic Conditions } \\
\text { Nutrition, Metabolism, or Development Disorders }\end{array}$ & $\begin{array}{l}13.3 \% \\
7.9 \% \\
6.3 \% \\
5.8 \% \\
5.3 \%\end{array}$ & 1729.646 & 687 & $.000 *$ \\
\hline $\begin{array}{l}\text { Cognitive Status } \\
\text { No Cognitive Impairment } \\
\text { Occasional Reminders } \\
\text { Some Assistance } \\
\text { Great Deal of Assistance } \\
\text { Severe Cognitive Impairment }\end{array}$ & $\begin{array}{l}26.4 \% \\
15.1 \% \\
17.3 \% \\
19.1 \% \\
12.1 \%\end{array}$ & 499.313 & 18 & $.000 *$ \\
\hline $\begin{array}{l}\text { Patient Total ADL Needs } \\
\text { None } \\
\text { One } \\
\text { Two } \\
\text { Three } \\
\text { Four } \\
\text { Five }\end{array}$ & $\begin{array}{c}8.4 \% \\
9.6 \% \\
8.2 \% \\
19.2 \% \\
26 \% \\
23.4 \%\end{array}$ & 602.953 & 21 & $.000^{*}$ \\
\hline
\end{tabular}

$* p$ values $\leq .05$ 
Table 82

Caregiver Utilization of Spiritual Services Based on Patient Level of Care, Length of Service, \& Payer Source

\begin{tabular}{|c|c|c|c|c|}
\hline & $\%$ of Those Who Used the Service & $\chi^{2}$ & df & $p$ \\
\hline $\begin{array}{l}\text { Level of Care } \\
\text { Routine Homecare } \\
\text { Continuous Home Care } \\
\text { General Inpatient } \\
\text { Inpatient Respite } \\
\end{array}$ & $\begin{array}{c}78.1 \% \\
3.2 \% \\
15.9 \% \\
1.1 \% \\
\end{array}$ & 1573.355 & 18 & $.000^{*}$ \\
\hline Length of Service & Average 80 days & 1444.529 & 879 & $.000^{*}$ \\
\hline $\begin{array}{l}\text { Payer Source } \\
\text { Medicare } \\
\text { Medicaid } \\
\text { Tricare } \\
\text { Department of Veteran Affairs } \\
\text { Worker's Compensation } \\
\text { Other Government Funding } \\
\text { Private Insurance } \\
\text { Long-Term Care Insurance } \\
\text { Self-Pay } \\
\text { No Charge for Care } \\
\text { Undetermined Payer Source } \\
\text { Other }\end{array}$ & $\begin{array}{l}79.8 \% \\
3.5 \% \\
.2 \% \\
1.3 \% \\
0 \% \\
.3 \% \\
8.2 \% \\
.7 \% \\
1.1 \% \\
1.8 \% \\
.1 \% \\
.7 \%\end{array}$ & 202.466 & 42 & $.000^{*}$ \\
\hline
\end{tabular}

$* p$ values $\leq .05$ 
Table 83

Caregiver Utilization of Spiritual Services Based on Patient Age at Discharge, Gender, Race, Ethnicity, Marital Status, \& Veteran Status

\begin{tabular}{|c|c|c|c|c|}
\hline & $\%$ of Those Who Used the Service & $\chi^{2}$ & $\mathrm{df}$ & $p$ \\
\hline Patient Age at Discharge & Average Age 75 & 203.787 & 150 & $.002 *$ \\
\hline $\begin{array}{l}\text { Gender } \\
\text { Male } \\
\text { Female }\end{array}$ & N.S. & .870 & 3 & .833 \\
\hline $\begin{array}{l}\text { Race } \\
\text { American Indian or Alaskan Native } \\
\text { Asian } \\
\text { Native Hawaiian or other Pacific Islander } \\
\text { Black or African American } \\
\text { White } \\
\end{array}$ & $\begin{array}{l}\text { N.S. } \\
.7 \% \\
\text { N.S. } \\
\text { N.S. } \\
92.2 \% \\
\end{array}$ & $\begin{array}{c}6.600 \\
20.153 \\
.066 \\
7.560 \\
8.968 \\
\end{array}$ & $\begin{array}{l}3 \\
3 \\
3 \\
3 \\
3\end{array}$ & $\begin{array}{l}.086 \\
.000^{*} \\
.996 \\
.056 \\
.030^{*}\end{array}$ \\
\hline $\begin{array}{l}\text { Ethnicity } \\
\text { Hispanic or Latino } \\
\text { White Non-Hispanic or Latino } \\
\text { Black Non-Hispanic or Latino } \\
\text { Other Non-Hispanic or Latino } \\
\end{array}$ & $\begin{array}{c}3.1 \% \\
88.1 \% \\
6 \% \\
1.5 \% \\
\end{array}$ & 198.141 & 12 & $.000^{*}$ \\
\hline $\begin{array}{l}\text { Marital Status } \\
\text { Married } \\
\text { Widowed } \\
\text { Divorced } \\
\text { Separated } \\
\text { Never Married } \\
\text { Living with a Partner } \\
\end{array}$ & $\begin{array}{c}43.6 \% \\
39.2 \% \\
6.6 \% \\
.9 \% \\
5.7 \% \\
.8 \% \\
\end{array}$ & 98.600 & 18 & $.000^{*}$ \\
\hline Veteran & $7.3 \%$ & 25.817 & 9 & $.002 *$ \\
\hline
\end{tabular}

$* p$ values $\leq .05$ 
Table 84

Caregiver Utilization of Spiritual Services Based on Patient Caregiver Identification \& Household Membership

\begin{tabular}{|c|c|c|c|c|}
\hline & $\%$ of Those Who Used the Service & $\chi^{2}$ & $d f$ & $p$ \\
\hline $\begin{array}{l}\text { Identification of the Caregiver } \\
\text { Spouse } \\
\text { Child } \\
\text { Parent } \\
\text { Other family Member } \\
\text { Non-Family Member } \\
\end{array}$ & $\begin{array}{c}33 \% \\
32 \% \\
2 \% \\
7 \% \\
16 \% \\
\end{array}$ & 225.246 & 18 & $.000 *$ \\
\hline $\begin{array}{l}\text { Household Membership } \\
\text { Alone } \\
\text { Family }\end{array}$ & $\begin{array}{c}8.2 \% \\
60.9 \%\end{array}$ & 196.088 & 15 & $.000 *$ \\
\hline $\begin{array}{l}\text { Spouse or Significant Other } \\
\text { Parent } \\
\text { Child } \\
\text { Other Family Members }\end{array}$ & $\begin{array}{c}31 \% \\
1 \% \\
17 \% \\
5 \%\end{array}$ & $\begin{array}{l}158.835 \\
163.110 \\
163.670 \\
137.444\end{array}$ & $\begin{array}{l}9 \\
9 \\
9 \\
9\end{array}$ & $\begin{array}{l}.000 * \\
.000 * \\
.000 * \\
.000 *\end{array}$ \\
\hline $\begin{array}{l}\text { Non-Family Members } \\
\text { Family and Non-Family }\end{array}$ & $\begin{array}{l}4.3 \% \\
.3 \%\end{array}$ & & & \\
\hline
\end{tabular}

$* p$ values $\leq .05$ 
Table 85

Caregiver Utilization of Spiritual Services Based on Patient Location at the Beginning as Well as End of Care

\begin{tabular}{|c|c|c|c|c|}
\hline & $\%$ of Those Who Used the Service & $\chi^{2}$ & $d f$ & $p$ \\
\hline $\begin{array}{l}\text { Location at the Beginning of Care } \\
\text { Private Home } \\
\text { Nursing Home/Skilled Nursing Facility } \\
\text { Hospital } \\
\text { Residential Care Place } \\
\text { Agency Inpatient/Residential Facility } \\
\text { Other }\end{array}$ & $\begin{array}{c}60.9 \% \\
18.7 \% \\
7.8 \% \\
3.5 \% \\
6.8 \% \\
.8 \%\end{array}$ & 1783.698 & 21 & $.000^{*}$ \\
\hline $\begin{array}{l}\text { Location at the End of Care } \\
\text { Private Home } \\
\text { Nursing Home/Skilled Nursing Facility } \\
\text { Hospital } \\
\text { Residential Care Place } \\
\text { Agency Inpatient/Residential Facility } \\
\text { Other }\end{array}$ & $\begin{array}{c}53.8 \% \\
21.3 \% \\
7.9 \% \\
3.5 \% \\
10.4 \% \\
1.3 \%\end{array}$ & 1784.961 & 21 & $.000^{*}$ \\
\hline
\end{tabular}

$* p$ values $\leq .05$ 
Dealing with difficult behavior services. Overall, 14.4\% of patients had caregivers that utilized dealing with difficult behaviors services. The majority of the patients had cancer diagnosis, specifically either the lung, bronchial, or tracheal form of the disease (12.1\%). Those with no cognitive impairment had a caregiver that used the service the most (25.3\%). Patients with four total ADL needs represented the most patients with caregivers that used this service (29.3\%). Hospice patients under routine home care represented $72.4 \%$ of patients with caregivers that used this service.

Patient length of service, payer source, age, and gender were not significantly related to use of dealing with difficult behaviors services. Asian racial identity was significantly related to caregiver use of this service. Asian patients accounted for .3\% of patients with caregivers that used dealing with difficult behaviors services. White nonHispanics represented the highest amount of patients with caregivers that used this service (85.9\%). Married patients accounted for $41.1 \%$ of patients with caregivers that used this service. Patient veteran status was not significant.

Patient with spousal caregivers or their child as the caregiver represented $66 \%$ of patients who used this service combined. Patients who lived with a family member accounted for most of the patients with caregivers that used this service (63.2\%). More specifically, those who had household membership with their spouse represented 33\% of those who lived with a family member. Patients that lived in a private home at the beginning of care accounted for $57.8 \%$ and those that lived in a private home at the end of care also represented the most patients that had a caregiver that used dealing with difficult behavior services (51.1\%). (see Tables 86-90) 


\section{Table 86}

Caregiver Utilization of Dealing with Difficult Behaviors Services Based on Patient Primary Diagnosis, Cognitive Status, \& Total ADL Needs

\begin{tabular}{|c|c|c|c|c|}
\hline & $\begin{array}{l}\% \text { of Those Who Used the } \\
\text { Service }\end{array}$ & $\chi^{2}$ & $\mathrm{df}$ & $p$ \\
\hline $\begin{array}{l}\text { Diagnosis } \\
\text { Lung, Bronchial, or Tracheal Cancer } \\
\text { Heart Failure } \\
\text { Unspecified Chronic Airway Obstruction } \\
\text { Other Organic Psychotic Chronic Conditions } \\
\text { Nutrition, Metabolism, or Developmental Disorders } \\
\text { Unknown Cause of Morbidity }\end{array}$ & $\begin{array}{c}12.1 \% \\
8 \% \\
6.3 \% \\
6 \% \\
5.5 \% \\
5.5 \%\end{array}$ & 1235.225 & 687 & $.000^{*}$ \\
\hline $\begin{array}{l}\text { Cognitive Status } \\
\text { No Cognitive Impairment } \\
\text { Occasional Reminders } \\
\text { Some Assistance } \\
\text { Great Deal of Assistance } \\
\text { Severe Cognitive Impairment }\end{array}$ & $\begin{array}{l}25.3 \% \\
13.5 \% \\
22.1 \% \\
22.1 \% \\
12.9 \% \\
\end{array}$ & 448.075 & 18 & $.000^{*}$ \\
\hline $\begin{array}{l}\text { Patient Total ADL Needs } \\
\text { None } \\
\text { One } \\
\text { Two } \\
\text { Three } \\
\text { Four } \\
\text { Five }\end{array}$ & $\begin{array}{c}10.1 \% \\
3.7 \% \\
6.9 \% \\
15.2 \% \\
29.3 \% \\
29 \%\end{array}$ & 546.557 & 21 & $.000^{*}$ \\
\hline
\end{tabular}

$* p$ values $\leq .05$ 
Table 87

Caregiver Utilization of Dealing with Difficult Behaviors Services Based on Patient Level of Care, Length of Service, \& Payer Source

\begin{tabular}{|c|c|c|c|c|}
\hline & $\%$ of Those Who Used the Service & $\chi^{2}$ & df & $p$ \\
\hline $\begin{array}{l}\text { Level of Care } \\
\text { Routine Homecare } \\
\text { Continuous Home Care } \\
\text { General Inpatient } \\
\text { Inpatient Respite } \\
\end{array}$ & $\begin{array}{c}72.4 \% \\
2.3 \% \\
9.2 \% \\
.3 \% \\
\end{array}$ & 728.203 & 18 & $.000^{*}$ \\
\hline Length of Service & N.S. & 815.263 & 879 & 939 \\
\hline $\begin{array}{l}\text { Payer Source } \\
\text { Medicare } \\
\text { Medicaid } \\
\text { Tricare } \\
\text { Department of Veteran Affairs } \\
\text { Worker's Compensation } \\
\text { Other Government Funding } \\
\text { Private Insurance } \\
\text { Long-Term Care Insurance } \\
\text { Self-Pay } \\
\text { No Charge for Care } \\
\text { Undetermined Payer Source } \\
\text { Other }\end{array}$ & N.S. & 53.309 & 42 & .113 \\
\hline
\end{tabular}

$* p$ values $\leq .05$ 
Table 88

Caregiver Utilization of Dealing with Difficult Behaviors Services Based on Patient Age at Discharge, Gender, Race, Ethnicity, Marital Status, \& Veteran Status

\begin{tabular}{|c|c|c|c|c|}
\hline & $\%$ of Those Who Used the Service & $\chi^{2}$ & df & $p$ \\
\hline Patient Age at Discharge & N.S. & 174.062 & 150 & .087 \\
\hline $\begin{array}{l}\text { Gender } \\
\text { Male } \\
\text { Female }\end{array}$ & N.S. & 1.103 & 3 & .776 \\
\hline $\begin{array}{l}\text { Race } \\
\text { American Indian or Alaskan Native } \\
\text { Asian } \\
\text { Native Hawaiian or other Pacific Islander } \\
\text { Black or African American } \\
\text { White }\end{array}$ & $\begin{array}{l}\text { N.S. } \\
.3 \% \\
\text { N.S. } \\
\text { N.S. } \\
\text { N.S. }\end{array}$ & $\begin{array}{c}7.447 \\
20.433 \\
1.270 \\
1.240 \\
.879\end{array}$ & $\begin{array}{l}3 \\
3 \\
3 \\
3 \\
3\end{array}$ & $\begin{array}{l}.059 \\
.000 * \\
.736 \\
.743 \\
.879\end{array}$ \\
\hline $\begin{array}{l}\text { Ethnicity } \\
\text { Hispanic or Latino } \\
\text { White Non-Hispanic or Latino } \\
\text { Black Non-Hispanic or Latino } \\
\text { Other Non-Hispanic or Latino }\end{array}$ & $\begin{array}{c}3.7 \% \\
85.9 \% \\
8.9 \\
.9 \% \\
\end{array}$ & 185.002 & 4 & $.000 *$ \\
\hline $\begin{array}{l}\text { Marital Status } \\
\text { Married } \\
\text { Widowed } \\
\text { Divorced } \\
\text { Separated } \\
\text { Never Married } \\
\text { Living with a Partner }\end{array}$ & $\begin{array}{c}41.1 \% \\
35.6 \% \\
9.8 \% \\
.9 \% \\
8.6 \% \\
.6 \% \\
\end{array}$ & 40.647 & 18 & $.002 *$ \\
\hline Veteran & N.S. & 13.712 & 9 & .133 \\
\hline
\end{tabular}

$* p$ values $\leq .05$ 
Caregiver Utilization of Dealing with Difficult Behaviors Services Based on Patient Caregiver Identification \& Household Membership

\begin{tabular}{|c|c|c|c|c|}
\hline & $\%$ of Those Who Used the Service & $\chi^{2}$ & $d f$ & $p$ \\
\hline $\begin{array}{l}\text { Identification of the Caregiver } \\
\text { Spouse } \\
\text { Child } \\
\text { Parent } \\
\text { Other family Member } \\
\text { Non-Family Member }\end{array}$ & $\begin{array}{c}33 \% \\
33 \% \\
4 \% \\
8 \% \\
15 \% \\
\end{array}$ & 115.537 & 18 & $.000^{*}$ \\
\hline $\begin{array}{l}\text { Household Membership } \\
\text { Alone } \\
\text { Family }\end{array}$ & $\begin{array}{l}10.9 \% \\
63.2 \%\end{array}$ & 37.311 & 5 & $.001^{*}$ \\
\hline $\begin{array}{l}\text { Spouse or Significant Other } \\
\text { Parent } \\
\text { Child } \\
\text { Other Family Members }\end{array}$ & $\begin{array}{l}33 \% \\
5 \% \\
21 \% \\
6 \%\end{array}$ & $\begin{array}{l}17.882 \\
18.456 \\
28.428 \\
18.432\end{array}$ & $\begin{array}{l}9 \\
9 \\
9 \\
9\end{array}$ & $\begin{array}{l}.037 * \\
.030^{*} \\
.001^{*} \\
.030^{*}\end{array}$ \\
\hline $\begin{array}{l}\text { Non-Family Members } \\
\text { Family and Non-Family }\end{array}$ & $\begin{array}{l}4.3 \% \\
1.1 \%\end{array}$ & & & \\
\hline
\end{tabular}

$* p$ values $\leq .05$ 
Caregiver Utilization of Dealing with Difficult Behaviors Services Based on Patient Location at the Beginning as Well as End of Care

\begin{tabular}{|c|c|c|c|c|}
\hline & $\%$ of Those Who Used the Service & $\chi^{2}$ & $d f$ & $p$ \\
\hline $\begin{array}{l}\text { Location at the Beginning of Care } \\
\text { Private Home } \\
\text { Nursing Home/Skilled Nursing Facility } \\
\text { Hospital } \\
\text { Residential Care Place } \\
\text { Agency Inpatient/Residential Facility } \\
\text { Other }\end{array}$ & $\begin{array}{c}57.8 \% \\
11.2 \% \\
5.7 \% \\
4.9 \% \\
4 \% \\
.9 \%\end{array}$ & 950.920 & 21 & $.000 *$ \\
\hline $\begin{array}{l}\text { Location at the End of Care } \\
\text { Private Home } \\
\text { Nursing Home/Skilled Nursing Facility } \\
\text { Hospital } \\
\text { Residential Care Place } \\
\text { Agency Inpatient/Residential Facility } \\
\text { Other }\end{array}$ & $\begin{array}{c}51.1 \% \\
16.4 \% \\
4.6 \% \\
6.3 \% \\
6.9 \% \\
1.1 \%\end{array}$ & 947.510 & 21 & $.000 *$ \\
\hline
\end{tabular}

$* p$ values $\leq .0$ 
Safety training services. Overall, 50.4\% of patients had caregivers that utilized safety training services. The majority of the patients had a diagnosis of lung, bronchial, or tracheal cancer (11.3\%). Those with no cognitive impairment had a caregiver that used the service the most (34.6\%). Patients with four total ADL needs represented the most patients with caregivers that used this service (27.7\%). Hospice patients under routine home care represented $60.5 \%$ of patients with caregivers that used this service. Patient length of service was not significant. Medicare patients represented $74.2 \%$ of those with caregivers that used this service. The average age of a patient with a caregiver who used this service was 75 years old.

Patient gender was not significant. Asian, Black or African American, and White racial identity were significantly related to caregiver use of safety training services. White patients used this service the most (88.4\%). Furthermore, White non-Hispanics represented the highest amount of patients with caregivers that used safety training services (82.7\%). Married patients accounted for $43 \%$ of patients with caregivers that used this service. Veterans represented $9.9 \%$ of patients with a caregiver that used this service.

Patient with spousal caregivers represented 37\% of patients who used this service. Patients who lived with a family member accounted for most of the patients with caregivers that used this service (68\%). More specifically, those who had household membership with their spouse represented $37 \%$ of those who lived with a family member. Patients that lived in a private home at the beginning of care accounted for $52.5 \%$ and 
those that lived in a private home at the end of care also represented the most patients that had a caregiver that used safety

training services (47.1\%). (see Tables 91-95)

Table 91

Caregiver Utilization of Safety Training Services Based on Patient Primary Diagnosis, Cognitive Status, \& Total ADL Needs

\begin{tabular}{|c|c|c|c|c|}
\hline & $\%$ of Those Who Used the Service & $\chi^{2}$ & df & $p$ \\
\hline $\begin{array}{l}\text { Diagnosis } \\
\text { Lung, Bronchial, or Tracheal Cancer } \\
\text { Heart Failure } \\
\text { Unspecified Chronic Airway Obstruction }\end{array}$ & $\begin{array}{l}11.3 \% \\
6.4 \% \\
6.1 \% \\
\end{array}$ & 1294.263 & 687 & $.000 *$ \\
\hline $\begin{array}{l}\text { Cognitive Status } \\
\text { No Cognitive Impairment } \\
\text { Occasional Reminders } \\
\text { Some Assistance } \\
\text { Great Deal of Assistance } \\
\text { Severe Cognitive Impairment }\end{array}$ & $\begin{array}{c}34.6 \% \\
18.3 \% \\
16.2 \% \\
16.2 \% \\
8.2 \%\end{array}$ & 420.887 & 18 & $.000 *$ \\
\hline $\begin{array}{l}\text { Patient Total ADL Needs } \\
\text { None } \\
\text { One } \\
\text { Two } \\
\text { Three } \\
\text { Four } \\
\text { Five }\end{array}$ & $\begin{array}{c}9.5 \% \\
5.3 \% \\
9.6 \% \\
19.8 \% \\
27.7 \% \\
22 \%\end{array}$ & 576.466 & 21 & $.000 *$ \\
\hline
\end{tabular}

$* p$ values $\leq .05$ 
Caregiver Utilization of Safety Training Services Based on Patient Level of Care, Length of Service, \& Payer Source

\begin{tabular}{|c|c|c|c|c|}
\hline & $\%$ of Those Who Used the Service & $\chi^{2}$ & df & $p$ \\
\hline $\begin{array}{l}\text { Level of Care } \\
\text { Routine Homecare } \\
\text { Continuous Home Care } \\
\text { General Inpatient } \\
\text { Inpatient Respite } \\
\end{array}$ & $\begin{array}{c}60.5 \% \\
2.1 \% \\
6.6 \% \\
.6 \% \\
\end{array}$ & 750.796 & 18 & $.000^{*}$ \\
\hline Length of Service & N.S. & 596.777 & 879 & 1.000 \\
\hline $\begin{array}{l}\text { Payer Source } \\
\text { Medicare } \\
\text { Medicaid } \\
\text { Tricare } \\
\text { Department of Veteran Affairs } \\
\text { Worker's Compensation } \\
\text { Other Government Funding } \\
\text { Private Insurance } \\
\text { Long-Term Care Insurance } \\
\text { Self-Pay } \\
\text { No Charge for Care } \\
\text { Undetermined Payer Source } \\
\text { Other }\end{array}$ & $\begin{array}{l}74.2 \% \\
9.3 \% \\
.3 \% \\
.7 \% \\
.2 \% \\
1 \% \\
8.5 \% \\
.1 \% \\
1.4 \% \\
.7 \% \\
.2 \% \\
.7 \% \\
\end{array}$ & 100.736 & 42 & $.000^{*}$ \\
\hline
\end{tabular}

$* p$ values $\leq .05$ 
Table 93

Caregiver Utilization of Safety Training Services Based on Patient Age at Discharge, Gender, Race, Ethnicity, Marital Status, \& Veteran Status

\begin{tabular}{|c|c|c|c|c|}
\hline & $\%$ of Those Who Used the Service & $\chi^{2}$ & df & $p$ \\
\hline Patient Age at Discharge & Average Age 75 & 200.856 & 150 & $.004 *$ \\
\hline $\begin{array}{l}\text { Gender } \\
\text { Male } \\
\text { Female } \\
\end{array}$ & N.S. & .973 & 3 & .808 \\
\hline $\begin{array}{l}\text { Race } \\
\text { American Indian or Alaskan Native } \\
\text { Asian } \\
\text { Native Hawaiian or other Pacific Islander } \\
\text { Black or African American } \\
\text { White }\end{array}$ & $\begin{array}{l}\text { N.S. } \\
.8 \% \\
\text { N.S. } \\
9.4 \% \\
88.4 \% \\
\end{array}$ & $\begin{array}{c}7.430 \\
19.043 \\
1.264 \\
10.252 \\
10.277 \\
\end{array}$ & $\begin{array}{l}3 \\
3 \\
3 \\
3 \\
3\end{array}$ & $\begin{array}{l}.059 \\
.000^{*} \\
.738 \\
.017^{*} \\
.016^{*}\end{array}$ \\
\hline $\begin{array}{l}\text { Ethnicity } \\
\text { Hispanic or Latino } \\
\text { White Non-Hispanic or Latino } \\
\text { Black Non-Hispanic or Latino } \\
\text { Other Non-Hispanic or Latino } \\
\end{array}$ & $\begin{array}{c}3.5 \% \\
82.7 \% \\
9.3 \% \\
2.1 \% \\
\end{array}$ & 189.319 & 12 & $.000^{*}$ \\
\hline $\begin{array}{l}\text { Marital Status } \\
\text { Married } \\
\text { Widowed } \\
\text { Divorced } \\
\text { Separated } \\
\text { Never Married } \\
\text { Living with a Partner }\end{array}$ & $\begin{array}{c}43 \% \\
35 \% \\
7.5 \% \\
.8 \% \\
9.2 \% \\
.9 \% \\
\end{array}$ & 55.470 & 18 & $.000^{*}$ \\
\hline Veteran & $9.9 \%$ & 17.517 & 9 & $.041 *$ \\
\hline
\end{tabular}

$* p$ values $\leq .05$ 
Caregiver Utilization of Safety Training Services Based on Patient Caregiver Identification \& Household Membership

\begin{tabular}{|c|c|c|c|c|}
\hline & $\%$ of Those Who Used the Service & $\chi^{2}$ & $d f$ & $p$ \\
\hline $\begin{array}{l}\text { Identification of the Caregiver } \\
\text { Spouse } \\
\text { Child } \\
\text { Parent } \\
\text { Other family Member } \\
\text { Non-Family Member }\end{array}$ & $\begin{array}{c}37 \% \\
32 \% \\
0 \% \\
10 \% \\
12 \% \\
\end{array}$ & 397.488 & 18 & $.000^{*}$ \\
\hline $\begin{array}{l}\text { Household Membership } \\
\text { Alone } \\
\text { Family }\end{array}$ & $\begin{array}{l}13 \% \\
68 \%\end{array}$ & 181.569 & 15 & $.000^{*}$ \\
\hline $\begin{array}{l}\text { Spouse or Significant Other } \\
\text { Parent } \\
\text { Child } \\
\text { Other Family Members }\end{array}$ & $\begin{array}{c}37 \% \\
21 \% \\
4 \% \\
8 \%\end{array}$ & $\begin{array}{c}106.379 \\
96.990 \\
127.681 \\
102.659\end{array}$ & $\begin{array}{l}9 \\
9 \\
9 \\
9\end{array}$ & $\begin{array}{l}.000^{*} \\
.000^{*} \\
.000^{*} \\
.000^{*}\end{array}$ \\
\hline $\begin{array}{l}\text { Non-Family Members } \\
\text { Family and Non-Family }\end{array}$ & $\begin{array}{l}3.8 \% \\
.7 \%\end{array}$ & & & \\
\hline
\end{tabular}

$* p$ values $\leq .05$ 
Caregiver Utilization of Safety Training Services Based on Patient Location at the Beginning as Well as End of Care

\begin{tabular}{|l|c|c|c|}
\hline & \% of Those Who Used the Service & $\chi^{2}$ & $d f$ \\
\hline Location at the Beginning of Care & & 1051.655 & 21 \\
Private Home & $52.5 \%$ & $.000 *$ \\
Nursing Home/Skilled Nursing Facility & $8.4 \%$ & \\
Hospital & $2.7 \%$ & \\
Residential Care Place & $2.1 \%$ & \\
Agency Inpatient/Residential Facility & $3.5 \%$ & \\
Other & $.7 \%$ & \\
\hline Location at the End of Care & & \\
Private Home & $47.1 \%$ & \\
Nursing Home/Skilled Nursing Facility & $10.3 \%$ & & \\
Hospital & $4.5 \%$ & & \\
Residential Care Place & $2.1 \%$ & & \\
Agency Inpatient/Residential Facility & $4.8 \%$ & & \\
Other & $.9 \%$ & & \\
\end{tabular}

$* p$ values $\leq .05$ 
Suspected abuse or neglect services. Overall, 6.1\% of patients had caregivers that utilized suspected abuse or neglect services. The majority of the patients had cancer diagnosis, specifically either the lung, bronchial, or tracheal form of the disease (8.8\%). Those with no cognitive impairment had a caregiver that used the service the most (29.7\%). Patients with two or five total ADL needs represented the most patients with caregivers that used this service ( $80 \%$ combined). Hospice patients under routine home care represented $43.4 \%$ of patients with caregivers that used this service.

Length of service was not significantly associated with use of this service. Medicare patients represented $62.2 \%$ of those with caregivers that used this service. Patient age was not significant. Females accounted for the most patients with caregivers who used this service. Asian racial identity was significantly related to caregiver use of suspected abuse or neglect services. Asian patients represented $1.4 \%$ of those who had caregivers that used this service. White non-Hispanics represented the highest amount of patients with caregivers that used bereavement services (80.4\%). Married patients accounted for $33.1 \%$ of patients with caregivers that used this service. Patient veteran status was not significant.

Patients with their child as the caregiver represented $31 \%$ of patients who used this service. Patients who lived with a family member accounted for most of the patients with caregivers that used this service (67\%). More specifically, those who had household membership with their spouse represented $27 \%$ of those who lived with a family member. Patients that lived in a private home at the beginning of care accounted for $39.9 \%$ and 
those that lived in a private home at the end of care also represented the most patients that had a caregiver that used

bereavement services (31.8\%). (see Tables 96-100)

Table 96

Caregiver Utilization of Suspected Abuse or Neglect Services Based on Patient Primary Diagnosis, Cognitive Status, \& Total ADL Needs

\begin{tabular}{|c|c|c|c|c|}
\hline & $\%$ of Those Who Used the Service & $\chi^{2}$ & df & $p$ \\
\hline $\begin{array}{l}\text { Diagnosis } \\
\text { Lung, Bronchial, or Tracheal Cancer } \\
\text { Heart Failure } \\
\text { Unspecified Chronic Airway Obstruction }\end{array}$ & $\begin{array}{l}8.8 \% \\
7.4 \% \\
5.4 \% \\
\end{array}$ & 1322.075 & 687 & $.000 *$ \\
\hline $\begin{array}{l}\text { Cognitive Status } \\
\text { No Cognitive Impairment } \\
\text { Occasional Reminders } \\
\text { Some Assistance } \\
\text { Great Deal of Assistance } \\
\text { Severe Cognitive Impairment }\end{array}$ & $\begin{array}{l}29.7 \% \\
10.8 \% \\
18.9 \% \\
18.2 \% \\
16.9 \%\end{array}$ & 415.571 & 18 & $.000^{*}$ \\
\hline $\begin{array}{l}\text { Patient Total ADL Needs } \\
\text { None } \\
\text { One } \\
\text { Two } \\
\text { Three } \\
\text { Four } \\
\text { Five }\end{array}$ & $\begin{array}{c}10.8 \% \\
4.7 \% \\
40 \% \\
0 \% \\
0 \% \\
40 \%\end{array}$ & 510.429 & 21 & $.000 *$ \\
\hline
\end{tabular}

$* p$ values $\leq .05$ 
Table 97

Caregiver Utilization of Suspected Abuse or Neglect Services Based on Patient Level of Care, Length of Service, \& Payer Source

\begin{tabular}{|c|c|c|c|c|}
\hline & $\%$ of Those Who Used the Service & $\chi^{2}$ & df & $p$ \\
\hline $\begin{array}{l}\text { Level of Care } \\
\text { Routine Homecare } \\
\text { Continuous Home Care } \\
\text { General Inpatient } \\
\text { Inpatient Respite } \\
\end{array}$ & $\begin{array}{c}43.4 \% \\
1.4 \% \\
10.8 \% \\
.7 \% \\
\end{array}$ & 649.501 & 18 & $.000^{*}$ \\
\hline Length of Service & N.S. & 540.417 & 879 & 1.000 \\
\hline $\begin{array}{l}\text { Payer Source } \\
\text { Medicare } \\
\text { Medicaid } \\
\text { Tricare } \\
\text { Department of Veteran Affairs } \\
\text { Worker's Compensation } \\
\text { Other Government Funding } \\
\text { Private Insurance } \\
\text { Long-Term Care Insurance } \\
\text { Self-Pay } \\
\text { No Charge for Care } \\
\text { Undetermined Payer Source } \\
\text { Other }\end{array}$ & $\begin{array}{c}62.2 \% \\
21.6 \% \\
0 \% \\
2.7 \% \\
.7 \% \\
.7 \% \\
7.4 \% \\
0 \% \\
.7 \% \\
.7 \% \\
0 \% \\
0 \%\end{array}$ & 69.072 & 42 & $.005 *$ \\
\hline
\end{tabular}

$* p$ values $\leq .05$ 
Table 98

Caregiver Utilization of Suspected Abuse or Neglect Services Based on Patient Age at Discharge, Gender, Race, Ethnicity, Marital Status, \& Veteran Status

\begin{tabular}{|c|c|c|c|c|}
\hline & $\%$ of Those Who Used the Service & $\chi^{2}$ & df & $p$ \\
\hline Patient Age at Discharge & Average Age 75 & 185.230 & 150 & $.027^{*}$ \\
\hline $\begin{array}{l}\text { Gender } \\
\text { Male } \\
\text { Female }\end{array}$ & N.S. & 1.144 & 3 & .766 \\
\hline $\begin{array}{l}\text { Race } \\
\text { American Indian or Alaskan Native } \\
\text { Asian } \\
\text { Native Hawaiian or other Pacific Islander } \\
\text { Black or African American } \\
\text { White }\end{array}$ & $\begin{array}{l}\text { N.S. } \\
1.4 \% \\
\text { N.S. } \\
\text { N.S. } \\
\text { N.S. }\end{array}$ & $\begin{array}{c}6.600 \\
18.798 \\
.532 \\
3.551 \\
3.225\end{array}$ & $\begin{array}{l}3 \\
3 \\
3 \\
3 \\
3\end{array}$ & $\begin{array}{l}.086 \\
.000^{*} \\
.912 \\
.314 \\
.358\end{array}$ \\
\hline $\begin{array}{l}\text { Ethnicity } \\
\text { Hispanic or Latino } \\
\text { White Non-Hispanic or Latino } \\
\text { Black Non-Hispanic or Latino } \\
\text { Other Non-Hispanic or Latino }\end{array}$ & $\begin{array}{c}4.1 \% \\
80.4 \% \\
11.5 \% \\
2 \%\end{array}$ & 180.940 & 12 & $.000 *$ \\
\hline $\begin{array}{l}\text { Marital Status } \\
\text { Married } \\
\text { Widowed } \\
\text { Divorced } \\
\text { Separated } \\
\text { Never Married } \\
\text { Living with a Partner }\end{array}$ & $\begin{array}{c}33.1 \% \\
30.4 \% \\
10.8 \% \\
2 \% \\
20.3 \% \\
.7 \%\end{array}$ & 62.195 & 18 & $.000 *$ \\
\hline Veteran & N.S. & 10.684 & 9 & 298 \\
\hline
\end{tabular}

$* p$ values $\leq .05$ 
Table 99

Caregiver Utilization of Suspected Abuse or Neglect Services Based on Patient Caregiver Identification \& Household Membership

\begin{tabular}{|c|c|c|c|c|}
\hline & $\%$ of Those Who Used the Service & $\chi^{2}$ & $d f$ & $p$ \\
\hline $\begin{array}{l}\text { Identification of the Caregiver } \\
\text { Spouse } \\
\text { Child } \\
\text { Parent } \\
\text { Other family Member } \\
\text { Non-Family Member } \\
\end{array}$ & $\begin{array}{c}27 \% \\
31 \% \\
8 \% \\
9 \% \\
15 \% \\
\end{array}$ & 109.077 & 18 & $.000^{*}$ \\
\hline $\begin{array}{l}\text { Household Membership } \\
\text { Alone } \\
\text { Family }\end{array}$ & $\begin{array}{l}11 \% \\
67 \%\end{array}$ & 85.201 & 15 & $.000^{*}$ \\
\hline $\begin{array}{l}\text { Spouse or Significant Other } \\
\text { Parent } \\
\text { Child } \\
\text { Other Family Members }\end{array}$ & $\begin{array}{l}27 \% \\
14 \% \\
19 \% \\
12 \%\end{array}$ & $\begin{array}{l}28.913 \\
55.550 \\
26.014 \\
29.517\end{array}$ & $\begin{array}{l}9 \\
9 \\
9 \\
9\end{array}$ & $\begin{array}{l}.001 * \\
.000 * \\
.002 * \\
.001 *\end{array}$ \\
\hline $\begin{array}{l}\text { Non-Family Members } \\
\text { Family and Non-Family }\end{array}$ & $\begin{array}{l}7 \% \\
.1 \%\end{array}$ & & & \\
\hline
\end{tabular}

$* p$ values $\leq .05$ 


\section{Table 100}

Caregiver Utilization of Suspected Abuse or Neglect Services Based on Patient Location at the Beginning as Well as End of Care

\begin{tabular}{|l|c|c|c|}
\hline & \% of Those Who Used the Service & $\chi^{2}$ & $d f$ \\
\hline Location at the Beginning of Care & & 874.143 & 21 \\
Private Home & $39.9 \%$ & $.000^{*}$ \\
Nursing Home/Skilled Nursing Facility & $5.4 \%$ & & \\
Hospital & $3.4 \%$ & & \\
Residential Care Place & $2.7 \%$ & \\
Agency Inpatient/Residential Facility & $5.4 \%$ & & \\
Other & $0 \%$ & & \\
\hline & & & \\
Location at the End of Care & $31.8 \%$ & & \\
Private Home & $10.1 \%$ & & \\
Nursing Home/Skilled Nursing Facility & $4.1 \%$ & & \\
Hospital & $2.7 \%$ & & \\
Residential Care Place & $8.1 \%$ & & \\
Agency Inpatient/Residential Facility & $0 \%$ & & \\
Other & & \\
\hline
\end{tabular}

$* p$ values $\leq .05$ 
Resource referral information services. Overall, 20.1\% of patients had caregivers that utilized resource referral information services. The majority of the patients had cancer diagnosis, specifically either the lung, bronchial, or tracheal form of the disease (8\%). Those with no cognitive impairment had a caregiver that used the service the most (27.2\%). Patients with four total ADL needs represented the most patients with caregivers that used this service (30\%). Hospice patients under routine home care represented $65.4 \%$ of patients with caregivers that used this service.

Patient length of service was not significant. Medicare patients represented 76.7\% of those with caregivers that used this service. The average age of patients that had a caregiver who used this service was 75 years old. Patient gender was not significantly associated with use of this service. Asian racial identity were significantly related to caregiver use of resource referral information services. Asian patients accounted for .4\% of patients who had a caregiver that used this service. White non-Hispanics represented the highest amount of patients with caregivers that used resource referral information services (85.2\%). Married patients accounted for $42.2 \%$ of patients with caregivers that used this service. Veterans represented $8.7 \%$ of patients with a caregiver that used this service.

Patient with spousal caregivers represented 34\% of patients who used this service. Patients who lived with a family member accounted for most of the patients with caregivers that used this service (63\%). More specifically, those who had household membership with their spouse represented 33\% of those who lived with a family member. 
Patients that lived in a private home at the beginning of care accounted for $53.3 \%$ and those that lived in a private home at the end of care also represented the most patients that had a caregiver that used bereavement services (45.3\%). (see Tables 101-

Table 101

Caregiver Utilization of Resource Referral Information Services Based on Patient Primary Diagnosis, Cognitive Status, \& Total ADL Needs

\begin{tabular}{|c|c|c|c|c|}
\hline & $\%$ of Those Who Used the Service & $\chi^{2}$ & df & $p$ \\
\hline $\begin{array}{l}\text { Diagnosis } \\
\text { Lung, Bronchial, or Tracheal Cancer } \\
\text { Heart Failure } \\
\text { Unspecified Chronic Airway Obstruction } \\
\text { Unknown Cause of Morbidity } \\
\text { Nutrition, Metabolism, or Developmental Disorder }\end{array}$ & $\begin{array}{c}8 \% \\
5.1 \% \\
5.3 \% \\
5.6 \% \\
5.3 \%\end{array}$ & 1221.343 & 687 & $.000^{*}$ \\
\hline $\begin{array}{l}\text { Cognitive Status } \\
\text { No Cognitive Impairment } \\
\text { Occasional Reminders } \\
\text { Some Assistance } \\
\text { Great Deal of Assistance } \\
\text { Severe Cognitive Impairment }\end{array}$ & $\begin{array}{c}31.3 \% \\
15.6 \% \\
17.1 \% \\
20.6 \% \\
8.4 \%\end{array}$ & 409.828 & 18 & $.000^{*}$ \\
\hline $\begin{array}{l}\text { Patient Total ADL Needs } \\
\text { None } \\
\text { One } \\
\text { Two } \\
\text { Three } \\
\text { Four } \\
\text { Five }\end{array}$ & $\begin{array}{l}12.1 \% \\
6.6 \% \\
9.1 \% \\
15.8 \% \\
30 \% \\
17.9 \%\end{array}$ & 514.577 & 21 & $.000 *$ \\
\hline
\end{tabular}

$* p$ values $\leq .05$ 


\section{Table 102}

Caregiver Utilization of Resource Referral Information Services Based on Patient Level of Care, Length of Service, \& Payer Source

\begin{tabular}{|c|c|c|c|c|}
\hline & $\%$ of Those Who Used the Service & $\chi^{2}$ & df & $p$ \\
\hline $\begin{array}{l}\text { Level of Care } \\
\text { Routine Homecare } \\
\text { Continuous Home Care } \\
\text { General Inpatient } \\
\text { Inpatient Respite } \\
\end{array}$ & $\begin{array}{c}65.4 \% \\
2.7 \% \\
9.1 \% \\
.6 \%\end{array}$ & 701.333 & 18 & $.000 *$ \\
\hline Length of Service & N.S. & 704.437 & 879 & 1.000 \\
\hline $\begin{array}{l}\text { Payer Source } \\
\text { Medicare } \\
\text { Medicaid } \\
\text { Tricare } \\
\text { Department of Veteran Affairs } \\
\text { Worker's Compensation } \\
\text { Other Government Funding } \\
\text { Private Insurance } \\
\text { Long-Term Care Insurance } \\
\text { Self-Pay } \\
\text { No Charge for Care } \\
\text { Undetermined Payer Source } \\
\text { Other }\end{array}$ & $\begin{array}{l}76.7 \% \\
7.4 \% \\
.2 \% \\
1.9 \% \\
0 \% \\
.4 \% \\
6.8 \% \\
.2 \% \\
1 \% \\
1 \% \\
0 \% \\
1.4 \%\end{array}$ & 73.091 & 42 & $.002 *$ \\
\hline
\end{tabular}

$* p$ values $\leq .05$ 
Table 103

Caregiver Utilization of Resource Referral Information Services Based on Patient Age at Discharge, Gender, Race, Ethnicity, Marital Status, \& Veteran Status

\begin{tabular}{|c|c|c|c|c|}
\hline & $\%$ of Those Who Used the Service & $\chi^{2}$ & df & $p$ \\
\hline Patient Age at Discharge & Average Age 75 & 184.65 & 150 & .029 \\
\hline $\begin{array}{l}\text { Gender } \\
\text { Male } \\
\text { Female } \\
\end{array}$ & N.S. & .156 & 3 & .984 \\
\hline $\begin{array}{l}\text { Race } \\
\text { American Indian or Alaskan Native } \\
\text { Asian } \\
\text { Native Hawaiian or other Pacific Islander } \\
\text { Black or African American } \\
\text { White }\end{array}$ & $\begin{array}{l}\text { N.S. } \\
.4 \% \\
\text { N.S. } \\
\text { N.S. } \\
\text { N.S. }\end{array}$ & $\begin{array}{c}7.177 \\
20.426 \\
2.290 \\
2.950 \\
1.618 \\
\end{array}$ & $\begin{array}{l}3 \\
3 \\
3 \\
3 \\
3\end{array}$ & $\begin{array}{l}.066 \\
.000 * \\
.514 \\
.399 \\
.655\end{array}$ \\
\hline $\begin{array}{l}\text { Ethnicity } \\
\text { Hispanic or Latino } \\
\text { White Non-Hispanic or Latino } \\
\text { Black Non-Hispanic or Latino } \\
\text { Other Non-Hispanic or Latino }\end{array}$ & $\begin{array}{c}3.3 \% \\
85.2 \% \\
9.5 \% \\
1.4 \%\end{array}$ & 187.752 & 12 & $.000 *$ \\
\hline $\begin{array}{l}\text { Marital Status } \\
\text { Married } \\
\text { Widowed } \\
\text { Divorced } \\
\text { Separated } \\
\text { Never Married } \\
\text { Living with a Partner }\end{array}$ & $\begin{array}{c}42.2 \% \\
35.6 \% \\
7 \% \\
1 \% \\
9.7 \% \\
.8 \%\end{array}$ & 40.254 & 18 & $.002 *$ \\
\hline Veteran & $8.7 \%$ & 32.692 & 9 & $.000 *$ \\
\hline
\end{tabular}

$* p$ values $\leq .05$ 


\section{Table 104}

Caregiver Utilization of Resource Referral Information Services Based on Patient Caregiver Identification \& Household Membership

\begin{tabular}{|c|c|c|c|c|}
\hline & $\%$ of Those Who Used the Service & $\chi^{2}$ & $d f$ & $p$ \\
\hline $\begin{array}{l}\text { Identification of the Caregiver } \\
\text { Spouse } \\
\text { Child } \\
\text { Parent } \\
\text { Other family Member } \\
\text { Non-Family Member } \\
\end{array}$ & $\begin{array}{c}34 \% \\
29 \% \\
4 \% \\
11 \% \\
15 \% \\
\end{array}$ & 113.060 & 18 & $.000^{*}$ \\
\hline $\begin{array}{l}\text { Household Membership } \\
\text { Alone } \\
\text { Family }\end{array}$ & $\begin{array}{l}13 \% \\
63 \%\end{array}$ & 87.306 & 15 & $.000^{*}$ \\
\hline $\begin{array}{l}\text { Spouse or Significant Other } \\
\text { Parent } \\
\text { Child } \\
\text { Other Family Members }\end{array}$ & $\begin{array}{c}33 \% \\
3 \% \\
17 \% \\
9 \%\end{array}$ & $\begin{array}{l}16.925 \\
16.963 \\
18.576 \\
21.150\end{array}$ & $\begin{array}{l}9 \\
9 \\
9 \\
9\end{array}$ & $\begin{array}{l}.050^{*} \\
.049 * \\
.029 * \\
.012 *\end{array}$ \\
\hline $\begin{array}{l}\text { Non-Family Members } \\
\text { Family and Non-Family }\end{array}$ & $\begin{array}{l}5 \% \\
.4 \%\end{array}$ & & & \\
\hline
\end{tabular}

$* p$ values $\leq .05$ 


\section{Table 105}

Caregiver Utilization of Resource Referral Information Services Based on Patient Location at the Beginning as Well as End of Care

\begin{tabular}{|c|c|c|c|c|}
\hline & $\%$ of Those Who Used the Service & $\chi^{2}$ & $d f$ & $p$ \\
\hline $\begin{array}{l}\text { Location at the Beginning of Care } \\
\text { Private Home } \\
\text { Nursing Home/Skilled Nursing Facility } \\
\text { Hospital } \\
\text { Residential Care Place } \\
\text { Agency Inpatient/Residential Facility } \\
\text { Other }\end{array}$ & $\begin{array}{c}53.3 \% \\
11.7 \% \\
4.7 \% \\
2.5 \% \\
5.1 \% \\
.4 \%\end{array}$ & 922.022 & 21 & $.000^{*}$ \\
\hline $\begin{array}{l}\text { Location at the End of Care } \\
\text { Private Home } \\
\text { Nursing Home/Skilled Nursing Facility } \\
\text { Hospital } \\
\text { Residential Care Place } \\
\text { Agency Inpatient/Residential Facility } \\
\text { Other }\end{array}$ & $\begin{array}{c}45.3 \% \\
17.1 \% \\
5.3 \% \\
2.3 \% \\
6.8 \% \\
1 \%\end{array}$ & 913.969 & 21 & $.000^{*}$ \\
\hline
\end{tabular}

$* p$ values $\leq .05$ 


\section{Conclusions}

\section{Psychosocial service availability}

Contrary to the first hypothesis of this study, for profit hospice agencies tend to have more availability of medical social services than hospice agencies with different ownership status (i.e. either not-for-profit or government owned) regardless if the agency is a part of a chain or agency size. Additionally, hospice agency ownership status does not significantly predict whether or not the following psychosocial services are made available to patients and families when agency chain status and size are controlled: grief or bereavement, resource referral, mental health support, respite, advanced directive support (i.e. assessment of whether that patient has advanced directives, provision of advanced directive information, provision of advanced directive forms, educating the patient about advanced directives, only providing advanced directive information when asked, and having restrictions on implementing advanced directives), as well as ethical counseling.

\section{Psychosocial service utilization}

Based on the results of the analyses, patients at for profit hospice agencies tend to utilize medical social services less than hospice agencies with another ownership status (i.e. not-forprofit or government owned) regardless if the agency is a part of a chain or patient total ADL needs. Additionally, hospice families/friends tend to utilize bereavement services less frequently at for profit agencies than those at hospice agencies with another ownership status when agency chain status and patient ADLs are taken in to account. Contrary to hypothesis number two, hospice agency ownership status did not significantly predict whether or not the following psychosocial services were utilized by patients and families once agency chain status and patient ADLs are controlled: resource referral, mental health support, respite, as well as ethical counseling. 


\section{Characteristics of consumers that utilized psychosocial services}

Overall, patient and caregiver utilization rates of psychosocial services were low with the exception of medical social services, bereavement services, spiritual care services, \& safety training services. The majority of individuals that used these services were married, White, non-Hispanic, 74-75 year old cancer patients with no cognitive impairment. Most were Medicare recipients with advanced directives in place and had 4 ADL needs. Routine home care patients with an average care continuum of about 2-2 1/2 months accounted for most of those who used these services.

The majority of these patients lived in a private residence with family members and had spousal caregivers. The hypothesis that underserved (e.g. racial and ethnic minorities), Medicaid recipients would utilize psychosocial services more than others was not supported. Patients that had higher need diagnoses as well as ADL needs however did have higher utilization rates than others. 


\section{CHAPTER V: DISCUSSION}

Information has been sparse on the hospice psychosocial support offered through the American hospice system. To date, much of the research on hospice care in the U.S. has been focused on the physical aspect of the care model and not on the mental, social, spiritual, economic, as well as environmental factors that can also impact terminally ill patients and loved ones.

Previous studies have indicated that variation can be observed in the care that hospice patients receive which has generated concern about the commercialization of care where patients may be vulnerable to not receiving optimal care (Aldridge et al., 2014; Ata et al., 2013; Carlson et al., 2004; Gandhi, 2012; Sack, 2007; “The Debate in Hospice Care”, 2008; Wachterman et al., 2011). This study aimed to focus on the specific psychosocial support that is offered through the American hospice care system as well as the utilization rates and demographics of the patients and families that are serviced under this form of health care. This is because the previous studies on hospice care in the U.S. have not comprehensively discussed the psychosocial components involved with this form of health care.

It was hypothesized that due to the influx of for profit hospices in this country that may have a model of care that is primarily focused on business opposed to patient care goals, for profit hospices would be least likely to provide adequate amounts of psychosocial services to patients when agency size and chain status were controlled. It was also hypothesized that the patients under the care of for profit hospices would be least likely to utilize psychosocial services. The results of this study show that ownership status was only a significant predictor of medical social service availability where for 
profit agencies were more likely to have this service available. Conversely, patients at not for profit and government owned agencies were more likely to utilize medical social services as well as bereavement services.

A variety of hospice psychosocial services were made available via all hospice providers sampled in the parent study. However, patient and caregiver utilization rates of these services were low with the exception of medical social services, bereavement services, spiritual care services, \& safety training services. The majority of individuals that used these services were married, White, non-Hispanic, 74-75 year old cancer patients with no cognitive impairment. Most were Medicare recipients with advanced directives in place and had 4 ADL needs. Routine home care patients with an average care continuum of about 2-2 1/2 months accounted for most of those who used these services. The majority of these patients lived in a private residence with family members and had spousal caregivers.

These results suggest that the psychosocial services that were available had an overall low utilization rate despite availability. Across hospice auspices, significant differences in medical social service availability as well as bereavement, spiritual, safety training, and medical social service utilization were observed when patient total ALD needs, agency size, and chain status were controlled. Medical social service during care and bereavement post care were the only medical social work services that significantly varied in availability and utilization. Though medical social services were more readily available at for profit hospices, they were less likely to be utilized at these agencies. Further detail into this phenomenon will be explored below. 
Further, psychosocial services are disproportionately underutilized by racial and ethnic minorities. These results highlight the disparity that exists between racial groups that are admitted under hospice care. Literature supports these findings suggesting that racial and ethnic minorities utilize hospice care services less and have higher disenrollment rates because of the preference of more aggressive care options such as those received in an e emergency care unit (Cohen, 2008; Fisherman et al., 2009; Unroe, 2012). In addition to variations in practical and theoretical worldviews, the disparities that are evident within the larger health care system, discrimination, and maltreatment that ethnic and racial minorities experience in this country has facilitated large scale mistrust among this subpopulation (Mazanec, Daly, \& Townsend, 2010).

These preferences in turn make a patient ineligible to receive hospice care congruently with invasive treatments based on Medicare enrollment requirements (CMS, 2013). Some argue that by forcing a patient and/or their family to select either hospice care or aggressive treatments has the potential to exacerbate these disparities because of the ethnic, racial, and cultural preference variations that exist within the terminally ill population (Fisherman et al., 2009). Social workers can engage in community involvement by becoming and/or collaborating with the hospice field educators in order to garnish a greater understanding of the needs of terminally ill minorities.

Terminally ill patients do have the option of enrolling into palliative care programs which have been developed to allow for certain pain relieving treatments and can be initiated at the onset of terminally decline opposed to waiting until the end stage where there is a life expectancy 6 months or less (U. S. National Library of Medicine, 2016). There have not been a significant amount of generalizable studies on the 
utilization of the palliative care model by minorities. The few published studies indicate that minority hospice enrollment rates are higher when patients receive palliative care first which lends to greater satisfaction with the hospice care model, increased documentation of treatment goals, along with an increased likelihood of death at home (Bell, Kuriya, \& Fischberg, 2011; Ciemins et al., 2006; Holley et al., 2009; Zaide et al., 2012). Social work researchers can examine this aspect further with more generalizable studies to determine if increased minority community education and access to palliative care programs as an early intervention model can assuage the disparities seen in the enrollment and continued utilization of hospice services.

\section{Theoretical Implications}

The Life-Span development theory reinforces that the aging population needs care that is multidimensional due to the complexities of problems that can be experienced as people advance in age (Hoyer, 2002). At the end of life, these complexities have the risk

of being heightened due to physical decline that ensues with a terminal illness in addition to the psychosocial factors that can be affected (e.g. emotional stability, familial dynamics, ethical concerns, and resource needs).

The Peaceful End of Life Theory suggested that by focusing on all aspects of pain that can occur at the end of life, the terminally ill can therefore feel holistically cared for and die in a more peaceful state (Ruland \& Moore, 1998). The interdisciplinary focused hospice model of care addresses these multifaceted care needs by having medical physician s, nurses, social workers, chaplains, and volunteers available. Making such a wide variety of specialists available can facilitate ease in the dying process more so than if end of life issues were to be address independently of one another. 
This notion that there is not only a consumer need for physical pain support but also psychosocial support can be evidenced by an average of about $50 \%$ utilization rate of bereavement, spiritual care, and safety training services at the time of the NHHC survey. However, the alarming lack of psychosocial service utilization across hospice auspices may yield further investigation into what psychosocial needs are present and how they may are addressed. Further, it lends deeper concern as to whether or not patients are receiving the end of life care they require in order to experience a peaceful death. For example, $60 \%$ of hospice patients and families in the parent study were not utilizing the available medical social services which can address issues ranging from mental health to resource referral. This may either indicate that such issues are not as prevalent as once assumed or it is possible that hospice consumers are having these issues addressed by other forms of intervention.

A recent retrograde study on the care hospice patients received in the last few days of life revealed that patient visits by the entire hospice staff varied depending on location of service, day of the death, and patient race (Teno, Plotzke, Christian, \& Gonzalo, 2016). Patients who died on Sundays, lived in a skilled nursing facility, and were Black received the least amount of care ((Teno, Plotzke, Christian, \& Gonzalo, 2016). These alarming results further highlight the concern of the quality of care being provided across hospice auspices. They may be explained by things such as professional burn-out, low staff availability, or limited regulation of visit requirement as in the case with social workers not having visit mandates beyond the initial assessment. At any rate, in order to have a "good death" the support experienced during the continuum of care should not be reduced, especially at the last stages of life.. 
The results of this study indicate that patients and families at government owned or not-for-profit hospices are four times more likely to utilize medical social services and three times more likely to use bereavement services than those under for profit care. This may indicate that the form of care that is available at for profit hospices has a significant impact on consumer utilization of medical social services and bereavement services.

These results may reinforce the Contract Failure theory that stipulates an increase in notfor-profit service utilization can result when quantity and/or quality of services are restricted (Hansmann, 1980).

At the time of the NHHC survey, there was no restriction in the quantity of psychosocial services being provided. In fact, medical social services where more available at for profit hospices than other providers. Moreover, for profit hospices were eight times more likely to have medical social services available than not-for-profit or government owned hospices when agency size and chain status were controlled. However, because of the significant difference shown between the auspices and service utilization, there may be a presence of quality variation.

These results may also be a reflection of the resource scarcity that many hospices face if they have to repay the government due to the excessive funds that are generated from care for patients that have longer lengths of service (over 180 days). Motivation to maximize profits and reduce expenditures may persuade agencies to provide fewer services seen as non-essential despite their availability as stipulated by the traditional microeconomic theory (Hosmer, 1984; Nicholson \& Snyder, 2008). Therefore despite that fact that many psychosocial services may be listed as available under agency care, the services may not be actively provided to conserve costs. Further identification and 
assessment of quality measures based on consumer views are highly needed to draw definitive conclusions on care model variations and their impact on hospice consumer service utilization.

Despite previous arguments, for-profit hospice agencies may not be as profitdriven as previous studies suggest. Despite the evidence of the overall limited utilization of psychosocial services available, many of which are not mandated by the Hospice Medicare Benefit, for profit hospices still made these services available during the time frame of the parent study. If for profit hospices were exclusively profit driven, then the focus on conservation of cost would limit and/or remove the availability of psychosocial services that remain under-utilized.

A more recent examination into human evolution and leadership motivation suggests a more interdisciplinary approach. Pluralistic motivations that take into consideration both the self-enhancement (self-interest) as well as the self-transcendent (altruistic) allow for businesses to accommodate both consumer as well as organizational needs as much as possible (Grant \& Patil, 2012; Murtaza, 2011). Hospice business models may not vary as widely as hypothesized and it is possible that all hospice types are operating under a more pluralistic model of care and not exclusively myopic leadership typologies of business orientation or altruism. What about the non-profit again you just focus on the for profit

\section{Implications for Social Work Research, Policy, Education and Practice}

The results of this study can aid in the building of foundational understanding of what psychosocial services are provided in the U.S. and can help researchers further develop, implement, and evaluate psychosocial interventions that are tailored specifically 
to hospice patients. Currently, there are few psychosocial interventions that have been developed and tested specifically for the hospice population and none are specific to underserved hospice populations (Allen et al., 2008; Carter, 2006; Csikai et al., 2013); Drossel et al., 2011; Gordon, 2013; Keefe et al., 2005; Kruse, et al., 2013; McMillan et al., 2006; McMillan et al., 2007; Moody, 2004; Northouse et al., 2007; Northouse et al., 2013; Ott \& Lueger, 2002, \& Steinhauser et al., 2009).

Interestingly, the majority of these interventions have been developed, tested, and implemented by nurses. Though hospice care is an interdisciplinary model of care where all practice and research professions can collaborate, there needs to be further development and evaluation of hospice social work interventions due to the focus on psychosocial constructs. To date, there have only been five published empirical studies on hospice psychosocial intervention outcomes, three of which were on the Attitude, Define, Alternatives, Predict, and Tryout (ADPAT) Problem-Solving Intervention (PSI) (Alcide \& Potocky, 2015; Dimiris et al., 2010; Dimiris et al., 2012; Washington et al., 2012). This intervention has shown to have significant practical effects when implemented, but actual dissemination and rigorous practice of the model in the field have yet to be evaluated (Alcide \& Potocky, 2015).

It is important to note that limitations do exist when conducting psychosocial intervention studies with the hospice population. Due to the impending death of the patient, social workers may only see a patient for a short time, making implementation of standardized modalities such as mental health interventions difficult if not impossible to implement (Reese, 2013; Reese et al., 2011). In addition, the social workers that are 
providing care may have objections to the rigor and/or modality of available interventions (such as administering an extensive battery questionnaire) (Reese, 2013).

Concern with how certain intervention models can affect patient and practitioner rapport also exists especially when it comes to the counseling aspect of the social worker role (Reese, 2013). It is an accepted practice that professionals such as nurses and physicians are engaging in the measurement of patient ailments during the visit. However, this primary focus on measurement may not be something that patients and families expect from social workers as the listening aspect of engagement is highlighted when dealing with counseling professionals. If social workers were to begin to focus on manualized interventions that necessitate more focus on assessment and measures opposed to rapport building and engagement, further decline in utilization in medical social services can ensue (Reese, 2013).

This highlights the need for more intervention developments that are specifically tailored to the unique needs of the hospice patient and caregiver population in order to address these limitations. Though the developers of the SWAT assessment tool have been working towards tailoring this measurement tool to eliminate such complications in the rapport between hospice consumers and social workers, other interventions can also be developed. It may be beneficial to have social work researchers investigate how hospice consumers view the rapport between themselves and the social workers, Researchers can inquire how consumer psychosocial needs can be measured without decline in rapport. This can further help guide practitioners in providing care that has empirical and/or theoretical basis in addition to considering consumer perspectives. This 
may encourage higher utilization of these services by consumers if positive outcomes can be observed that are based on their perspective.

Further investment into educational and practical training on hospice end-of-life care and available intervention models need to ensue. Currently, hospice social work practitioners are unable to concisely indicate the practice models that they use with patients and it may be a reflection on the limited education in hospice and end of life care provided by social work programs and possible lack of proper guidance in the professional dictation of hospice social work practice (Reese, 2013).

Since the field of hospice is interdisciplinary in nature, social worker students and practitioners interested in hospice care need to be educated on the proper manner in which to chart patient assessments, narratives, and measurable outcomes so that other disciplines will be able to seamlessly understand and communicate regarding the care of their respective patients. This may also improve consumer utilization of psychosocial services overall as team collaboration on patient care improves.

Literature suggests that unlike other fields such as medicine and nursing, social workers receive end-of-life education that is insufficiently based in research and theoretical concepts (Christ \& Sormanti, 2000). This is not only a call to action for social work education reform, but also enhancement in proper leadership social workers receive to properly serve terminally ill patients. Social workers feel as though they lack the proper guidance and training which facilitates lack of preparation to work in this field (Christ \& Sormanti, 2000). Perhaps the lack of proper education and training may be evident in practice and cause a decline in the utilization of medical social services that can be provided by medical social workers. 
Recently, some post-secondary educational institutions have begun to provide certification in palliative and end of life care. The oldest of these programs was developed by the school of social work at Smith College. The program provides participants a condensed program over the course of two weekends with a focus on topics such as on theory, bereavement, ethical and legal issues, and leadership (Smith College of Social Work, 2016). The California State University also provides certification in hospice and palliative care (California State University, 2016). However, the programs at Smith College as well as The California State University require the participants to be actively in the field two years post-MSW.

The National Association of Social Workers also provides hospice social workers basic as well as advanced certification in hospice and palliative care (NASW, 2016). However, these certifications do not provide training in hospice and palliative care. Social workers seeking certification only need to provide evidence of education, years of experience, continuing education credits, state licensure (as applicable) and references in order to be approved as certified hospice and palliative social workers (CHP-SW or ACHPSW) (NASW, 2016).

Other continuing education options exist for practicing hospice social workers such as those that may be provided through agencies, conferences, or online education, but with the limited availability of education regarding end of life care prior to entering into the field, problems remain with lack of practice preparation. The University of Iowa uniquely provides social work students end of life training prior to entering into the field and attempts to comprehensively prepare students interested in this specialty with a solid foundation of educational training in the field of hospice and palliative care (The University 
of Iowa, 2016). An increase in programs that facilitate exposure to end of life social work practice prior to entering into the field can enhance interest in the field but also adequate preparation.

Further limitations arise if social workers only conduct "as needed” visits as suggested by the policy changes implemented by CMS for cost conservation (Cherin et al, 2010; Gandhi, 2012). If social workers are only conducting the initial assessments required by CMS upon admission and then only contacting patients when there is a pressing need or crisis present, rapport may not be built and the psychosocial needs that are common during this stage in life may be getting addressed via other sources or not at all. Further evaluation needs to be conducted to understand the impact that such regulatory policies may have on consumer service utilization, social work practice and the limitations it can present on research efforts.

As it pertains to the nursing discipline, the hospice Medicare policy mandates visits a minimum of every 14 days which allots them more access to patient cases and insight into intervention needs (CMS, 2008). This can sometimes lend to the blurring of discipline roles with nurses addressing psychosocial issues and less frequently making referrals to the team social worker due to the convenience of visit frequency, familiarity with patient cases, and possible desire to address patient care needs rapidly (Reese, 2011; Reese, 2013; Reese \& Raymer, 2004; Reith \& Payne, 2009).

Since social workers have the unique training in person-in-environment centered care, they may be more sensitive to the strengths of hospice patients and families. Further, the worldview of ethnic and racial minorities can be catered to more effectively lending to more personalized patient care and possibly increasing diverse patient utilization of these 
services. This may highlight the need for policy reform from the macro-practice standpoint. By tailoring and/or redefining practice regulations towards patient care models that increase involvement of practitioners with a culturally sensitive person-in-environment focus, there may be an increase in not only the utilization of psychosocial services but also an increased opportunity to evaluate the outcomes of these care models.

Continued investigation into hospice psychosocial services is essential in order to ensure that hospice consumers are receiving the quality care they deserve at the end of life. By obtaining insight into the associated with psychosocial service utilization, patient and family care goals, interventions as well as community outreach can be tailored more specifically address patient and family needs with respect to enhancing hospice patient diversity. Practitioners, educators and researchers have an opportunity to work with politicians to create a reformed hospice health care system that continues to focus on patient quality of life that is inclusive of not only physical care, but also psychosocial needs.

Additionally, having a clear understanding of psychosocial services and service utilization can inform hospice consumers regarding future choices and opportunities related to end-of-life care. Also, greater attention can to be placed on the underserved communities of terminally ill patients and their families. By using the results of this and other studies on hospice care, community educators, physicians, and family members may be able to directly target a larger market of the patient population and provide care that is catered specifically to their needs.

\section{Limitations}


Data from the 2007 National Home and Hospice Care Survey was collected during the time period when for-profit hospices where still increasing while the amount of not-for-profit hospice providers began to decline (MedPAC, 2013). It is unknown whether or not this external factor had any influence on the participating hospices' responses despite the rigor of the study. Another limitation to note is that the quality of psychosocial hospice service delivery cannot be concluded from this or any available literature to-date due to lack of substantive measures (MedPAC, 2013).

In addition, the lack of direct contact with hospice patients and their families and/or friends presents a reduction of the emotive and esoteric experience of hospice psychosocial service delivery that can be elicited by qualitative methods such as inperson interviews. Another limitation is that certain conclusions cannot be drawn due to the lack of availability of some variables of interest (such as patient spiritual/religious beliefs, agency availability of patient caregiver wellness services, or patient/family use of companionship service). Finally, the fact that certain psychosocial services may not have been used by some patients and families may be only related to agency ownership status but also the fact that non-mandatory service(s), were not needed.

It should be noted that the analyses that were conducted for research question number three were exploratory. The vast number of analyses that were conducted has the potential of increasing the likelihood of Type I error. Further rigorous study should be conducted in this area to evaluate service necessity, especially for underserved populations. Despite these limitations, this study uniquely provides a comprehensive examination into the psychosocial services in the American hospice system.

\section{Future Directions}


Further evaluation into the psychosocial needs of terminally ill patients need to be conducted. Since this study reveals that most patients are not fully utilizing the psychosocial service being provided by hospice care agencies, a clear understanding of patient needs can determine whether the current services need to be adjusted and/or supplemented. Additionally, evaluation of the specific needs of patients that are underserved is critical in enhancing the utilization of hospice care in the U.S. If care continues to be underutilized by ethnic and racial minorities, a large part of the American population will not be adequately served at the end of life with care that is focused on quality of life. Further investigation into why these services are underutilized by certain racial and ethnic groups and whether there is a need for change would enhance the understanding of what end-of-life care needs remain to be addressed within underserved communities.

As discussed, psychosocial intervention models of care specific to the hospice population need to be enhanced and further evaluated. It may be insightful to reevaluate the current psychosocial intervention models that are used by hospice practitioner. If the literature does not reflect a large availability of effective interventions specific to hospice patients, a better understanding of what practice models are being used may guide researchers to evaluate and understand the outcomes that are currently being yielded. This may also inform researchers of what type of interventions will be practical in implementation outside of the research setting.

This study contributes to the existing literature by providing a comprehensive examination of hospice psychosocial care in America. Due to the limited research available on this subject, researchers have a foundational bases as to what psychosocial 
services have been made available, which have been utilized, as well as the characteristics that may be associated with use of hospice psychosocial services. By enhancing the information available on hospice psychosocial services as a whole, further evaluation of consumer needs, agency practices, as well as quality assessments can ensue. 


\section{REFERENCES}

Alcide, A. \& Potocky, M. (2015). Adult hospice social work intervention outcomes in the United States. Journal of Social Work in End-of-Life \& Palliative Care, 11(3-4), 367-385.

Aldridge, M.D., Schlesinger, M., Barry, C.L., Morrison, R.S., McCorkle, R., Hürzeler, R., \& Bradley, E.H. (2014). National hospice survey results: For-profit status, community engagement, and service. Journal of American Medical Association Internal Medicine, 174(4), 500-506.

Allen, R.S., Hilgeman, M.M., Ege, M.A., Shuster, J.L., Burgio, L.D. (2008). Legacy activities as interventions approaching the end of life. Journal of Palliative Medicine, 11, 1029-38.

American Psychiatric Association (2013). Diagnostic and statistical manual of mental disorders ( $5^{\text {th }}$ ed.). Arlington, VA: American Psychiatric Publishing.

Arber, A. (2007). "Pain talk” in hospice and palliative care team meetings: An ethnography. International Journal of Nursing Studies, 44, 916-926.

Ata, B., Killaly, B. L., Olsen, T. L., Parker, R. P. (2013). On hospice operations under Medicare reimbursement policies. Management Science, 59(5), 1027-1044.

Bar-Tal, D. (1986). Altruistic motivation to help: Definition, utility, and operationalization. Humboldt Journal of Social Relations, 13(1/2), 3-14.

Bath, D. M. (2010). Separation from loved ones in the fear of death. Death Studies, 34, 404-425.

Bell, C. L., Kuriya, M., \& Fischlberg, D. (2011). Hospice referral and code status” Outcomes of inpatient palliative care consultations among Asian Americans and Pacific Islanders with cancer. Journal of Pain and Symptom Management, 42, 557-564.

Block, S. R. (2001). Governance of nonprofit organizations. J. Ott \& L. Dicke (Eds.). In Understanding nonprofit organizations: Governance, leadership, and management. Colorado: Westview Press.

Brock, D. W. \& Buchanan, A. E. (1987). The profit motive in medicine. Journal of Medical Philosophy, 12(1), 1-35.

Buckey, J. W. \& Abell, N. (2010). Life-sustaining Treatment Decisions: A Social Work Response to Meet Needs of Health Care Surrogates.” Journal of Social Work in End-of-life and Palliative Care, 6(1-2), 27-50. 
Caregivers. (2014). In CINAHL Headings. Retrieved from http://eds.b.ebscohost.com/ehost/mesh?sid=c655a25c-03ab-44d9-82141bd39b592eaf\%40sessionmgr198\&vid=1\&hid=103.

Caring Connections (2014). Advanced Directives. Retrieved from http://www.caringinfo.org/i4a/pages/index.cfm?pageid=3284 .

Carlson, M.D. A., Gallo, W. T., \& Bradley, E.H. (2004). Ownership status and patterns of care in hospice: Results from the National Home and Hospice Care Survey. Medical Care, 42(5), 432-438.

Carter, P.A. (2006). A brief behavioural sleep intervention for family caregivers of persons with cancer. Cancer \& Nursing, 29, 95-103.

Center for Medicare Advocacy, Inc. (2010). New Hospice Regulations, June 2008. Retrieved from http://www.medicareadvocacy.org/Print/2008/Hospice_08_07.31.NewRegs.htm.

Centers for Medicare \& Medicaid Services. (2008, April).CMS Manual System (Publication No. 100-04 Medicare Claims Processing). Retrieved from Regulations and Guidance via Transmittals: http://www.cms.gov/Regulationsand-Guidance/Guidance/Transmittals/downloads/R1494CP.pdf.

Centers for Medicare \& Medicaid Services (2012, June). Medicare Benefit Policy Manual. Coverage of hospice services under hospital insurance (Publication No. 100-04 Medicare Claims Processing). Retrieved from Regulations and Guidance via Transmittals: http://www.cms.gov/Regulations-andGuidance/Guidance/Transmittals/Downloads/R2766CP.pdf.

Centers for Medicare \& Medicaid Services (2013, August). CMS Manual System (Publication No. 100-04 Medicare Claims Processing). Retrieved from Regulations and Guidance via Transmittals: http://www.cms.gov/Regulationsand-Guidance/Guidance/Transmittals/Downloads/R2766CP.pdf.

Centers for Medicare \& Medicaid Services (2014a). Hospice. Retrieved from http://www.cms.gov/Research-Statistics-Data-and-Systems/Files-forOrder/CostReports/Hospice.html.

Centers for Medicare \& Medicaid Services (2014b). Hospice Item Set (HIS). Retrieved from http://www.cms.gov/Medicare/Quality-Initiatives-Patient-AssessmentInstruments/Hospice-Quality-Reporting/Hospice-Item-Set-HIS.html. 
Centers for Medicare \& Medicaid Services (2014c). Local coverage determinations for hospice- Determining terminal status. Retrieved from, http://www.cms.gov/medicare-coveragedatabase/Local+Coverage+Determination+for+Hospice++Determining+Terminal+Status+(L25678).

Cherlin, E. J., Carlson, M. D. A., Herrin, J., Schulman-Green, D., Barry, C. L., McCorkle, R., Johnson-Hurzeler, R., \& Bradley, E. H. (2010). Interdisciplinary staffing patterns: Do for-profit and nonprofit hospices differ? Journal of Palliative Medicine, 13(4), 389-394.

Chochinov, H. M., Hack, T., Hassard, T., Kristjanson, L. J., McClement, S., \& Harlos, M. (2002). Dignity in the terminally ill: A cross-sectional, cohort study. Lancet 360, 21(28), 2026-2030.

Christ, G. \& Blacker, S. E. (2009). Social work role in palliative care. In S. Diwan (Ed.), Health Care and Older Adults Resource Review. CSWE Gero-Ed Center, Master's Advanced Curriculum Project. Retrieved from http://www.cswe.org/File.aspx?id=24173.

Christ, G. H., \& Sormanti, M. (2000). Advancing social work practice in end-of-life care. Social Work in Health Care, 30(2), 81-99.

Ciemins, E. L., Stuart, B., Gerber, R., Newman, J. , \& Bauman, M. (2006). An evaluation of the Advanced Illness Management (AIM) Program: Increasing hospice utilization in the San Francisco Bay area. Journal of Palliative Medicine, 9, 1401-1411.

Cohen, L. L. (2008). Racial/ethnic disparities in hospice care: a systematic review. Journal of Palliative Medicine, 11(5), 763-768.

Corr, C. (2009). Hospice, history of. In C. Bryant, \& D. Peck (Eds.), Encyclopedia of death and the human experience. (pp. 586-589). Thousand Oaks, CA: SAGE Publications, Inc.

Csikai, E., Allen, R., \& Parmelee, P. (2013). The evidence of efficacy in the translation of the legacy intervention family enactment (LIFE) .Journal of Pain and Symptom Management, 45(2), 427-428.

Demiris, G., Parker Oliver, D., Washington, K., Fruehling, L. T., Haggarty-Robbins, D., Doorenbos, A., Wechkin, A. \& Berry, D. (2010). A Problem Solving Intervention for Hospice Caregivers: A Pilot Study. Journal of Palliative Medicine, 13(8), 1005-1011.

Demiris, G., Oliver, D. P., Wittenberg-Lyles, E., Washington, K., Doorenbors, A., Rue, T., \& Berry, D. (2012). A noninferiority trial of a problem-solving intervention for hospice caregivers: In person versus videophone. Journal of Palliative Medicine, 15(6), 653-660. 
Demmer, C. (2004). A survey of complimentary therapy services provided by hospices. Journal of Palliative Medicine, 7(4), 510-516.

Docker, C. (1996). Advance Directives/Living Wills in S. McLean (Ed.) Contemporary Issues in Law, Medicine and Ethics. Vermont. Dartmouth Publishing Company.

Drossel, C., Fisher, J. E., Mercer, V. (2011). A DBT skills training group for family caregivers of persons with dementia. Behavior Therapy, 42, 109-119.

Empeño, J., Raming, N. T. J., Irwin, S. A., Nelesen, R. A., \& Lloyd, L. S. (2011). The Hospice Caregiver Support Project: Providing Support to Reduce Caregiver Stress. Journal of Palliative Medicine. 14(5), 593-597.

Evans, M. (February 2014). For-profit hospices incur Medicare penalties over longer stays, study finds. Modern Health Care. Retrieved from, http://www.modernhealthcare.com/article/20140224/NEWS/302249944.

Fisherman, J., O’Dwyer, P., Lu, H. L., Henderson, H. R., Asch, D. A., \& Casarett, D. J. (2009). Race, treatment preferences, and hospice enrollment: eligibility criteria may exclude patients with the greatest needs of care. Cancer, 115(3), 689-697.

Froelich, K. A. (2012). Hospice of the Red River Valley: A nonprofit's response to forprofit competition. Nonprofit Management \& Leadership, 23(2), 237-257.

Gandhi, S. O. (2012). Differences between non-profit and for-profit hospices: Patient selection and quality. International Journal of Health Care, Finance, and Economics, 12, 107-127.

Gliatto, M. F. \& Rai, A. K. (1999). Evaluation and treatment of patients with suicidal ideation. American Family Physician, 59(6), 1500-1505.

Grant, A., \& Patil, S. (2012). Challenging the norm of self-interest: Minority influence and transitions to helping norms in work units. Academy of Management Review, 37(4), 547-568.

Grief. (2010). A. Stevenson in Oxford Dictionary of English ( $3^{\text {rd }}$ ed.). New York: Oxford University Press.

Gordon, T. A. (2013) Good grief: Exploring the dimensionality of grief experiences and social work support. Journal of Social Work in End-Of-Life \& Palliative Care, 9(1), 27-42.

Hackbarth, G.M. (2008). Reforming the delivery system: MedPAC report to Congress. Retrieved from http://www.medpac.gov/documents/Jun08_EntireReport.pdf. 
Hansmann, H. B. (1980). The role of nonprofit enterprise. Yale Law Journal, 89(5), 835901.

Henson, R. G. (1988). Butler of Selfishness and self-love. Philosophy and Phenomenological Research, 49(1), 31-57.

Holley, A. P., Gorawara-Bhat, R., Dale, W., Hemmerich, J., \& Cox-Hayley, D. (2009). Palliative access through care at home: Experiences with an urban, geriatric home palliative care program. Journal of the American Geriatric Society, 57, 19251931.

Hosmer, L. T. (1984). Managerial ethics and microeconomic theory. Journal of Business Ethics, 3, 315-335.

Hospice Foundation of America. (2013). What is hospice? Retrieved from http://www.hospicefoundation.org/whatishospice.

Hoyer, W., J. (2002). Life-Span Development. In Encyclopedia of Aging. Retrieved from http://www.encyclopedia.com/doc/1G2-3402200233.html.

IBM Corp. Released 2010. IBM SPSS Statisitcs for Windows, Version 19.0. Armonk, NY: IBM Corp.

Internal Revenue Service (2014a). Corporations. Retrieved from http://www.irs.gov/Businesses/Small-Businesses-\&-Self-Employed/Corporations.

Internal Revenue Service (2014b). Difference between nonprofit and tax-exempt status. Retrieved from http://www.irs.gov/Charities-\&-Non-Profits/Applying-forExemption-Difference-Between-Nonprofit-and-Tax-Exempt-Status.

Kearl, M. (2009). Aging, the elderly, and death. In C. Bryant, \& D. Peck (Eds.), Encyclopedia of death and the human experience. (pp. 26-28). Thousand Oaks, CA: SAGE Publications, Inc.

Keefe, F.J., Ahles, T.A., Sutton, L., Dalton, J.A., Baucom, D., \& Pope, M.S. (2005). Partner-guided cancer pain management at the end of life: A preliminary study. Journal of Pain and Symptom Management, 29, 263-72.

Kilbourn, K. M., Costenaro, A., Madore, S., DeRoche, K., Anderson, D., Keech, T., \& Kutner, J. S. (2011). Feasibility of a telephone-based counseling program for informal caregivers of hospice patients. Journal of Palliative Medicine, 14(11), 1200-1205.

Kinzbrunner, B. M. (2002). For profit versus not-for-profit hospice: it is the quality that counts. Journal of Palliative Medicine, 5(4), 483-485. 
Kruse R. L., Parker Oliver, D., Wittenberg-Lyles ,E., Demiris, G. (2013). Conducting the ACTIVE randomized trial in hospice care: Keys to success. Clinical Trials, 10(1), 160-169.

Lindrooth, R.C., Weisbrod, B.A. (2007). Do religious nonprofit and for-profit organizations respond differently to financial incentives? The hospice industry. Journal of Health Economics, 26(2), 342-357.

Lutz, S. (2011). The history of hospice and palliative care. Current Problems in Cancer, 35(6), 304-309.

Mazanec, P. M., Daly, B. J., \& Townsend, A. (2010). Hospice utilization and end-of-life care decision making of African Americans. Journal of Hospice and Palliative Care, 27(8), 560-566.

Medicare Payment Advisory Commission Medicare Payment Advisory Commission (2009). Medicare payment policy: MedPAC report to Congress. Retrieved from http://www.medpac.gov/chapters/mar09_ch12.pdf .

Medicare Payment Advisory Commission Medicare Payment Advisory Commission (2013). Medicare payment policy: MedPAC report to Congress. Retrieved from http://www.medpac.gov/chapters/mar13_ch12.pdf .

Merriam, S. B., Courtenay, B. C., \& Reeves, P. M. (1997). Ego development in the face of death: How being HIV positive affects movement through Erikson's adult stages of development. Journal of Adult Development, 4(4), 221-235.

McMillan, S.C., Small, B.J., Weitzner, M., Schonwetter, R., Tittle, M., \& Moody, L. (2006). Impact of coping skills intervention with family caregivers of hospice patients with cancer. Cancer, 106, 214-22 (Nurses and Home Health Aids)

McMillan, S. C., \& Small, B. J. (2007). Using the COPE Intervention for Family Caregivers to Improve Symptoms of Hospice Homecare Patients. Oncology Nursing Society, 34(2), 313-312.

Miller, P. J., \& Mike, P. B. (1995). The Medicare Hospice Benefit: Ten years of federal policy for the terminally ill. Death Studies, 19, 531-542.

Moody, L.E., Webb, M., Cheung, R., Lowell, J. (2004). A focus group for caregivers of hospice patients with severe dyspnea. American Journal of Palliative Care, 21(2), 121-130.

Morefield, B., Plotzke, M., Patel. M., Lucas, K., Harrison, Z., Abt Associates Inc., Centers for Medicare \& Medicaid Services (n.d.). Hospice cost reports: 
Benchmarks and trends, 2004- 2011. Retrieved from http://www.nahc.org/assets/1/7/CostReportAAHPM.pdf.

National Association of Social Workers. (2004). NASW standards for social work practice in palliative and end-of-life care. Washington, DC. NASW Press.

National Association of Social Workers (2016). The Certified Hospice and Palliative Social Worker (CHP-SW). Retrieved from https://www.socialworkers.org/credentials/credentials/chpsw.asp.

National Center for Health Statistics. (2007). National Home and Hospice Care Survey, 2007. [Data File]. Retrieved from http://www.icpsr.umich.edu/icpsrweb/ICPSR/series/00041.

National Hospice and Palliative Care Association. (2013a). About hospice care. Retrieved from http://www.nhpco.org/about/hospice-care.

National Hospice and Palliative Care Association. (2013b). Facts and figures. Retrieved from http://www.nhpco.org/sites/default/files/public/Statistics_Research/2013_Facts_Fi gures.pdf.

National Hospice and Palliative Care Association. (2014a). Palliative care: An explanation of palliative care. Retrieved from http://www.nhpco.org/palliativecare-0.

National Hospice and Palliative Care Association. (2014b). Performance Measures. Retrieved from http://www.nhpco.org/performancemeasures.

Nicholas, E., Sullivan, T., Ide, B., Shreffler-Grant, J., \& Weinert, C. (2005). Health care choices: Complimentary therapy, chronic illness, and older rural dwellers. Journal of Holistic Nursing, 23(4), 381-394.

Nicholson, W. \& Snyder, C. (2008). Microeconomic Theory: Basic Principles and Extensions. Ohio: Thomson/South-Western.

Nicosia, N., Reardon, E., Lorenz, K, Lynn, J., \& Buntin, M.B. (2009). The Medicare hospice payment system: a consideration of potential refinements. Health Care Financing Review, 30(4), 47-59.

Northouse, L.L., Mood, D.W., Schafenacker, A., Montie. J.E., Sandler, H.M., Forman, J.D. (2007). Randomized clinical trial of a family intervention for prostate cancer patients and their spouses. Cancer, 110, 2809-2818. 
Northouse, L.L., Mood, D.W., Schafenacker, A.; Kalemkerian, G.; Zalupski, M., LoRusso, P. Hayes, D.F.., Hussain, M., Ruckdeschel, J., Fendrick, A. M., Trask, P.C., Ronis, D.L., \& Kershaw, T. (2013). Randomized Clinical trial of a brief and extensive dyadic intervention for advanced cance patients and their family caregivers. Psycho-Oncology, 22(3), 555-563.

Murtaza, N. (2011). Pursuing self-interest or self-actualization? From capitalism to a steady-state, wisdom economy. Ecological Economics, 70(4), 577-584.

Oliver, D. P., Wittenberg-Lyles, E., Demiris, G., Washington, K., Porock, D., \& Day, M. (2008). Barriers to pain management: Caregiver perceptions and pain talk by hospice interdisciplinary teams. Journal of Pain \& Symptom Management, 36(4), 374-382.

Ott, C. H. \& Leuger, R. J. (2002). Patterns of change in mental health status during the first two years of spousal bereavement. Death Studies, 25, 387-411.

Perry, J. E. \& Stone, R. C. (2011). In the business of dying: questioning the commercialization of hospice. Journal of Law and Medical Ethics, 39(2), 224234.

Pleacher, K. (2011). Providing a good death. Critical Care Medicine, 39(5), 1235-1236.

profit motive. (2002). In E. D. Hirsch, Jr., J. F. Kett, \& J. Trefil, The New Dictionary of Cultural Literacy (3rd ed.). Boston: Houghton Mifflin.

psychosocial factors. (2014). In CINAHL Headings. Retrieved from http://eds.b.ebscohost.com/ehost/mesh?sid=c655a25c-03ab-44d9-82141bd39b592eaf\%40sessionmgr198\&vid=3\&hid=103

Reese, D. J. (2011). Interdisciplinary perceptions of the social work role in hospice: Building upon the classic Kulys and Davis study. Journal of Social Work in EndOf-Life \&Palliative Care, 7(4), 383-406.

Reese, D. J. (2013). Hospice Social Work. New York: Columbia University Press.

Reese, D. J. \& Raymer, M. (2004). Relationships between social work services \& hospice outcomes: Results of the National Hospice Social Work Survey. Social Work, 49(3), 415-422.

Reese, D. J., Raymer, M., Orloff S. F., Gerbin, S., Valade, R., Dawson, S., Butler, C., Wise-Wright, M., \& Huber, R., (2006). The Social Work Assessment Tool (SWAT), Journal of Social Work in End-Of-Life \& Palliative Care, 2 (2), 65-95. 
Reith, M. \& Payne, M. (2009). Social Work in End-of-Life and Palliative Care. Chicago. Lyceum.

Rhymes, J. (1990). Hospice care in America. JAMA, 264, 369-372.

Rousseau, P. (2000). Death denial. Journal of Oncology Practice, 18(23), 3998-3999.

Rosenau, P. V., \& Linder, S. H. (2003). Two decades of research comparing for-profit and nonprofit health provider performance in the United States. Social Science Quarterly, 84(2), 219-241.

Rossman, P. (1977). Hospice: Creating new models of care for the terminally ill. New York: Fawcett.

Ruland, C. M. \& Moore, S. M. (1998). Theory construction based on standards of care: a proposed theory of the peaceful end of life. Nursing Outlook, 46, 169-175.

Sack, K. (2007 November). In hospice care, longer lives mean money lost. New York Times, p. 27 Retrieved from http://www.nytimes.com/2007/11/27/us/27hospice.html?pagewanted=all\&_r=0.

Saunders, C. (2000). Evolution of palliative care. Patient Education and Counseling, 41, 7-13.

Saunders, D. C. (2001). Social work and palliative care- the early history. British Journal of Social Work, 31, 791-799.

Smith College of Social Work (2016). Post Graduate Certificate in Palliative and End of Life Care. Retrieved from http://www.smith.edu/ssw/acad_cont_graduate_elc.php.

Steinhauser, K. E., Alexander, S. C., Byock, I. R., George, L. K., \& Tulsky, J. A. (2009). Seriously ill patients' discussions of preparation and life completion: An intervention to assist with transition at the end of life. Palliative and Supportive Care, 7, 393-404.

Taylor-Brown, S., Altilio, T., Blacker, S., Christ, G., \& Walsh-Burke, K. (2001). Best practices in end of life care. Philadelphia, PA: Society for Leadership in Social W ork and Health Care.

Teno, J. M., Plotzke, M., Christian, T., \& Gozalo, P. (2016)/ Examining variation in hospice visits by professional staff in the last 2 days of life. JAMA Internal Medicine, 176(3), 364-370. 
The California State University (2016). Post-MSW Palliative Care Certificate. Retrieved from https://csupalliativecare.org/programs/postmswcertificate/.

“The debate in hospice care” (2008). Journal of Oncology Practice, 4(3), 154-15. doi: 10.1200/JOP.0838503.

The University of Iowa (2016). End-of-Life Care Course Sequence. Retrieved from http://clas.uiowa.edu/socialwork/graduate-program/end-life-care-fieldpractice/end-life-care-course-sequence.

Unroe, K. T., Greiner, M .A., Johnson, K. S., Curtis, L. H., \& Setoguchi, S. (2012). Racial differences in hospice use and patterns of care after enrollment in hospice among Medicare beneficiaries with heart failure. American Heart Journal, 163(6), 987-993.

U.S Department of Health and Human Services (2014). Organ Donation. Retrieved from http://www.organdonor.gov/about/organdonation.html.

U.S. National Library of Medicine (2016). What is Palliative Care? Retrieved from https://www.nlm.nih.gov/medlineplus/ency/patientinstructions/000536.htm.

Wachterman, M. W., Marcantonio, E.R., Davis, R. B., \& McCarthy, E.P. (2011). Association of hospice agency profit status with patient diagnosis, location of care, and length of stay. JAMA, 305(5), 472-479.

Washington, K. T., Demiris, G., Parker Oliver, D., Wittenberg-lyles, E., Crumb, E. (2012). Qualitative evaluation of a problem-solving intervention for informal hospice caregivers Palliative Medicine, 26(8), 1018-1024.

Werth, J. L., Gordon, J. R., \& Johnson, R. R. (2002). Psychosocial issues near the end of life. Aging \& Mental Health, 6(4), 402-412.

Wilder, H. M., Oliver, D. P., Demiris, G., \& Washington, K. (2008). Informal hospice caregiving: The toll on quality of life. Journal of Social Work End-of-Life \& Palliative Care, 4(4), 312-332.

Wittenberg-Lyles, E., Demiris, G., Oliver, D. P., \& Burt, S. (2011). Reciprocal suffering: Caregiver concerns during hospice care. Journal of Pain \& Symptom Management, 41(2), 383-393.

Wittenberg-Lyles, E., Demiris, G., Oliver, D. P., Washington, K., Burt, S., \& Shaunfield, S. (2012). Stress variances among informal hospice caregivers. Qualitative Health Research, 22(8), 1114-1125. 
Zaide, G. B., Pekmezaris, R., Nouryan, C. N., Mir, T. P., Sison, C. P., Liberman, T., ...,, \& Wolf-Klein, G. P. (2013). Ethnicity, race, and advance directives in an inpatient palliative care consultation service. Palliative Supportive Care, 11(1), 5-11. 


\section{APPENDIX}

\section{Hospice Care}

Hospice care in the United States is a Medicare regulated medical provider under Part A for individuals that have been certified terminally ill by a medical doctor (MD) or doctor of osteopathy (DO) (Centers for Medicare and Medicaid Services [CMS], 2012). An individual is considered terminally ill, according to CMS (2013a), when their life expectancy is no longer than six months based on normal disease trajectory. Hospice provides interdisciplinary, non-curative support to the patient and their families (National Hospice and Palliative Care Organization [NHPCO], 2013a).

The care provided under hospice services differentiates from palliative end-of-life care in that palliative treatment interventions are accessible at an earlier stage in the disease process (National Association of Social Workers [NASW], 2004; NHPCO, 2014). Interventions such as the election of chemotherapy by a cancer patient are accessible whereas this service is not financially supported under hospice care per Medicare restrictions (CMS, 2012).

The required hospice interdisciplinary team as indicated by Medicare guidelines consists of a physician, nurse, certified nurse assistant, social worker, spiritual counselor, and volunteer (CMS, 2012). Other supporting disciplines such as music therapy, occupational as well as speech therapies can be provided as supported by the patient plan of care needs as deemed appropriate by each member of the interdisciplinary team (NHPCO, 2013a). The aim of the service is to assist in the relief of "total pain” (physical, mental, emotional, social, and spiritual) at the end-of-life (Saunders, 2001). Ownership Status 
Ownership status of an organization is identified based on the agency's federal tax status (Brock \& Buchanan, 1987; Internal Revenue Service [IRS]a, 2014). Not-for-profit or non-profit status is a concept based on state rather than federal law that may afford the identified organization as exemption from certain state level taxes such as property or income taxes (IRSa, 2014). By law these board of director governed agencies are not allowed to appropriate surplus revenues once all expenses have been allocated; however none of the funding can be allocated to any board members (Block, 2001; Brock \& Buchanan, 1987). For-profit agencies, also considered proprietary institutions or corporations, are owned by independent investors or stockholders who are allowed the freedom of accumulating surplus revenue with the regulation of paying both state and federal taxes (IRS, 2014a; Brock \& Buchanan, 1987).

Hospice agencies can be government owned, not-for-profit, or for profit (NHPCO, 2013a). Due to the limited availability of literature on hospice psychosocial services, this study will comprehensively examine all forms of hospice agencies based on ownership status. Primary attention given to the psychosocial services that are available, utilized, as well as the characteristics of patients and families utilizing these services. Type of Hospice Agency

The four types of hospice agencies in the U.S. are defined as free standing/independent, or ones that are a part of a hospital, home health agency, or nursing institution (NHPCO, 2013b).

Size of Hospice Agency

There are several ways to determine the size of a hospice agency. Examining average daily census, number of annual admissions, or determining whether the agency is 
a part of a chain can all indicative of agency size (NHPCO, 2013b). Large hospices are considered to have an average of over 100 patients per day, moderate size agencies between 25-100 patients per day, and small agencies with less than 25 patients per day (NHPCO, 2013b).

Agency Chain Status

Hospice agency chain status refers to whether or not the agency is a part of a chain of hospices.

Psychosocial Services

Resource Referral

Resource referral is defined generally as information provision and linkage to private and public service providers. These services may be organized and/or arranged by the referral source but are not provided by them directly (National Center for Health Statistics [NCHS], 2007).

\section{Mental Health Services}

Within hospice care, the diagnosis and specific treatment of mental health disease is not financially reimbursed under the Medicare Hospice Benefit (CMS, 2012a). However, assessment and support of some of the mental health issues that may occur while under hospice services are addressed as deemed clinically appropriate and indicated by the patient plan of care.

Depression symptoms are defined separately from normative grief reactions within the hospice setting (Werth et al., 2002). When a patient suffers clinical depression, they may suffer from symptoms that appear similar to grief such as poor appetite, decline in energy and activity, and diminished concentration (Werth et al., 2002). However 
Werth et al. (2002) explains that these are considered neurovegetative factors are in fact normal indicators of the physical decline that occur during the disease process. The authors indicate that intense suicidal ideation, feelings of guilt, worthlessness, helplessness, and/or hopelessness are more indicative of possible depressive symptoms with terminal patients and caregivers (Werth et al., 2002).

General anxiety as defined by the fifth revision of Diagnostic and Statistical Manual of Mental Disorders (DSM-V) is uncontrolled worry that is uncontrolled for at least 6 months (American Psychiatric Association, 2013). Denial of a terminal illness is defined as a mechanism of defense intended to negate the threat of disease to a person and their daily life (Rousseau, 2000). Suicidal ideation is defined as preoccupation or contemplation of self-inflicted cause of death (Gliatto \& Rai, 1999).

\section{Advanced Directives}

Advanced directives are state specific legal documents that guide the care a person wishes to receive or decline if they are mentally incapable of making their own decisions (Caring Connections, 2014; Docker, 1996). Components that are considered as subcategories of advanced directives in hospice care are health care proxy, durable power of attorney, living will, do not resuscitate order, and organ donation (Caring Connections, 2014; NCHS, 2007).

A healthcare proxy identifies the individual that has been designated by a patient to make health care related decisions for them in case they are deemed incapable of making those choices for themselves or known to others (NCHS, 2007). Durable power of attorney allots for a broader range of issues as should a patient become incapable of speaking and/or making decisions for his or her self, the durable power of attorney that 
they have designated for them can act on their behalf (NCHS, 2007). Living wills are documents indicating the patient's wishes regarding life-sustaining procedures (Caring Connections, 2014; NCHS, 2007). A do not resuscitate (DNR) order is provided by a medical doctor indicating that a patient is not to be revived should they stop breathing or if their heart were to stop (NCHS, 2007). Finally, organ donation refers to the extraction of certain organs, tissues, and body parts such as eye corneas from the patient post-death or while living for the purposes to transfer to another individual (NCHS, 2007; U.S. Department of Health and Human Services, 2014).

Grief

Grief is the natural response to the loss in any form but most commonly refers to loss as a result of death (grief, 2010).

\section{Ethical Issues Counseling}

For the purposes of this proposal, ethical issues counseling will encompass endof-life issues pertaining to things such as ventilator support termination, artificial nutrition limitations, and legal issues regarding patient care (NASW, 2004).

\section{Respite Care}

Respite care, defined under the Medicare Hospice Benefit as Inpatient Respite Care, is intermediate assistance for caregivers, by placing the hospice patient in an approved facility based on respective state regulations (CMS, 2012a). 
VITA

\section{AMARY ALCIDE}

2007

B.S., Psychology

Florida A \& M University

Tallahassee, FL

2008

$2008-2009$

Patricia P. Vance MSW Student of the Year Nominee Florida State University

Tallahassee, FL

White and Gold Key National Honor Society

Florida State University

Tallahassee, FL

Mental Health Therapist

Healing Transitions

Tallahassee, FL

2009

MSW Clinical Social Work

Florida State University

Tallahassee, FL

Phi Alpha National Social Work Honor Society Florida State University

Tallahassee, FL

Golden Key International Honor Society

Florida State University

Tallahassee, FL

Victoria E. Warner Graduate Scholarship Award

Florida State University

Tallahassee, FL

2009- 2010

HIV/AIDS Case Manager

Big Bend Cares

Tallahassee, FL

2010- 2011

Hospice Social Worker

Covenant Hospice

Tallahassee, FL 
Hospice Social Worker

Hospice of Palm Beach and Broward County

Ft. Lauderdale, FL

2013

Licensed Clinical Social Worker

State of Florida

Advanced Certification in Hospice and Palliative CareSocial Work (ACHP-SW)

Certification as a Clinical Social Worker in

Gerontology (CSW-G)

Ronald E. McNair Scholar Doctoral Fellowship Award

Qualified Supervisor for Clinical Social Workers

State of Florida

2013- 2016

Doctoral Candidate

Florida International University

Miami, FL

\section{PUBLICATIONS AND PRESENTATIONS}

Alcide, A., \& Potocky, M. (2015). Adult hospice social work intervention outcomes in the United States. Journal of Social Work in End-of-Life \& Palliative Care, 11(3-4), 367-385.

Alcide, A. (February, 2015). Adult Hospice Psychosocial Intervention Outcomes. Poster presented at the $3^{\text {rd }}$ Annual Social Work Hospice and Palliative Care Conference, Philadelphia, Pennsylvania. 